UNIVERSIDADE DE SÃO PAULO

ESCOLA DE ENFERMAGEM DE RIBEIRÃO PRETO

MARIA ANGÉLICA MOTTA DA SILVA ESSER

ATUAÇÃO DA ENFERMEIRA OBSTÉTRICA:

COMPREENDENDO A SUA VIVÊNCIA E A REALIDADE DA ASSISTÊNCIA

RIBEIRÃO PRETO

2016 


\section{ATUAÇÃO DA ENFERMEIRA OBSTÉTRICA: COMPREENDENDO A SUA VIVÊNCIA E A REALIDADE DA ASSISTÊNCIA}

Tese apresentada à Escola de Enfermagem de Ribeirão Preto da Universidade de São Paulo, para obtenção do título de Doutor em Ciências, Programa de Pós-Graduação Enfermagem em Saúde Pública.

Linha de Pesquisa: Assistência à Saúde da Mulher no Ciclo Vital

Orientadora: Prof. ${ }^{\text {a }}$ Dr. ${ }^{\text {a }}$ Fabiana Villela Mamede

\section{RIBEIRÃO PRETO}


Autorizo a reprodução e divulgação total ou parcial deste trabalho, por qualquer meio convencional ou eletrônico, para fins de estudo e pesquisa, desde que citada a fonte.

Esser, Maria Angélica Motta da Silva Esser

Atuação da Enfermeira Obstétrica: Compreendendo a sua vivência e a realidade da assistência. Ribeirão Preto, 2016.

224 p. : il. ; $30 \mathrm{~cm}$

Tese de Doutorado, apresentada à Escola de Enfermagem de Ribeirão Preto/USP. Área de concentração: Enfermagem Saúde Pública.

Orientador: Fabiana Villela Mamede

1. Enfermagem Obstétrica. 2. Photovoice. 3.Estudo Qualitativo. 4. Saúde da Mulher. 
ESSER, Maria Angélica Motta da Silva

Atuação da Enfermeira Obstétrica: compreendendo a sua vivência e a realidade da assistência.

Tese apresentada à Escola de Enfermagem de Ribeirão Preto da Universidade de São Paulo, para obtenção do título de Doutor em Ciências, Programa de Pós-Graduação Enfermagem em Saúde Pública.

Aprovado em / 2016.

Comissão Julgadora

Prof. Dr.

Instituição: Assinatura:

Prof. Dr.

Instituição: Assinatura:

Prof. Dr.

Instituição: Assinatura:

Prof. Dr.

Instituição: Assinatura:

Prof. Dr.

Instituição: Assinatura: 
Dedico este trabalho à minha família, à minha filha Bianca e ao meu esposo Wendel, por compreenderem meus momentos de ausência $e$ me incentivarem sempre que precisei. 
À minha orientadora, Prof $^{a}$. Dr ${ }^{a}$. Fabiana Villela Mamede

Agradeço por compartilhar comigo seu conhecimento, pela competência e entusiasmo em todos os momentos, desde os tempos da residência na Mater.

Muito obrigada por ser um exemplo de profissional, me acolhendo nas idas e vindas e em todas as minhas dificuldades. Muito obrigada pela amizade, respeito, simplicidade $e$ dedicação.

Por compreender a distância física, por estarmos muito longe e ao mesmo tempo muito perto, e entender minhas limitações, me apoiando em todas as ocasiões.

Sua presença como minha orientadora fez toda diferença em minha caminhada acadêmica na EERP, sempre disponível, confiando no meu trabalho e dando o suporte quando precisei.

Saiba que é referência para mim, como excelente profissional, mãe e mulher.

Que Deus continue abençoando teus passos e que te proteja sempre. 


\section{AGRADECIMENTOS}

A Deus por ter me dado forças para concluir mais este sonho, por estar sempre presente em minha vida.

À minha mãe Elza, meu irmão Júnior, minha cunhada Cintia e meu sobrinho Lucas, por acreditarem em mim, por estarem comigo nesta caminhada, me incentivando sempre, e por serem essenciais durante a operacionalização do cotidiano de minha residência, para que eu pudesse me ausentar e desenvolver esta pesquisa com tranquilidade.

Ao meu pai Milton e a sua esposa Silvana, por me darem suporte nos momentos em que precisei e por sempre apoiarem meus estudos.

Às Profas. Dra. Maria José Clapis e Dra. Juliana Stefanello, pelas contribuições e sugestões no exame de qualificação.

À minha amiga Maria de Lourdes Sperandio, pelo carinho e pelas contribuições feitas neste trabalho. Saiba que levarei comigo todos os seus ensinamentos.

À amiga irmã Renata Baldo, que esteve presente nos momentos em que precisei, por transmitir o verdadeiro sentimento de amizade e companheirismo. Por sempre me apoiar e me guiar, me inspirar e ser um exemplo a seguir.

À minha eterna "vizinha” Renata Frigeri, que me ofereceu o suporte necessário para que eu pudesse entender o mundo mágico da fotografia, por ser eficiente e estar sempre disponível. 
Obrigada pela indicação do Marcos Aurélio e da Karina Rampazzo para o cuidado especial nas figuras e imagens. Ficaram lindas! Muito obrigada!

Ao Marcos Rambalducci, por ser meu amigo e confidente, pelo incentivo e reconhecimento nesta jornada, por acreditar em meu potencial e impulsionar a minha carreira. Serei eternamente grata.

À Família Dornellas, por serem uma grata surpresa, sinônimo de amizade, felicidade e cumplicidade.

À minha amiga Renata Alves, por ser uma voz amiga nos momentos de estudo nas madrugadas. Saiba que suas palavras de conforto foram essenciais para que eu chegasse até aqui.

Ao meu amigo Cleiton, por ser meu irmão em muitas ocasiões, por acreditar em mim, me apoiar e incentivar em todos os momentos. Saiba que levarei sua amizade por toda minha vida.

À todos os meus amigos da Faculdade Pitágoras de Londrina, em especial aos gestores André Zago, Rafael, Lia, Bruno, Gilberto, Marisa, Tércia e Carla, que, além de me incentivarem, vivenciaram comigo esta trajetória, as alegrias e angústias inerentes a este processo. 
À todos os meus amigos, especialmente, Luciane Stahl, Deise, Tatiane, Patrícia Januário, Andressa, Geisa, Iara, Palmiane, Ana Olympia, Solange, Marcell, Karen e Mariana, por me apoiarem em vários momentos desta caminhada.

À minha amiga Maria Graziela Baron, por me ajudar em mais este desafio. Valeu!

À todos os docentes das disciplinas cursadas na pós-graduação da Escola de Enfermagem de Ribeirão Preto e Faculdade de Saúde Pública da Universidade de São Paulo, que, durante todo o processo, foram atenciosos, pacientes e competentes ao transmitirem seus conhecimentos.

Aos funcionários da Escola de Enfermagem de Ribeirão Preto, pelo carinho e amizade, por facilitarem o acesso às informações pertinentes ao programa.

À todas as enfermeiras obstétricas que contribuíram com este estudo e puderam compartilhar suas histórias de vida. Saibam que aprendi muito com cada uma de vocês! 
A coisa mais indispensável a um homem é reconhecer o uso que deve fazer do seu próprio conhecimento.

Platão 


\section{RESUMO}

ESSER, M. A. M. S. Atuação da enfermeira obstétrica: compreendendo a sua vivência e a realidade da assistência. 2016. 224f. Tese (Doutorado) - Escola de Enfermagem de Ribeirão Preto, Universidade de São Paulo. Ribeirão Preto, 2016.

Muitos esforços mundiais têm sido empregados para melhorar as condições de saúde na gestação e nascimento. A cada ano, aproximadamente 350 mil mulheres morrem durante a gravidez ou parto, sendo que $99 \%$ dessas mortes acontecem em países em desenvolvimento. O Ministério da Saúde vem desenvolvendo ações no sentido de melhorar o quadro da assistência materna, promovendo atividades para qualificar os profissionais e fomentar a atenção obstétrica e neonatal humanizada baseada em evidências científicas, além de garantir os direitos sexuais e reprodutivos das mulheres brasileiras. O cenário encontrado é de marginalização da enfermagem obstétrica; a enfermeira obstétrica apresenta dificuldades na atuação, tanto na realização de consultas obstétricas quanto no acompanhamento do parto e nascimento. Sua prática se mostra desprivilegiada de poder, pois não há reconhecimento da sua qualificação profissional. Este estudo tem como objetivos compreender a vivência da enfermeira obstétrica no cenário da admissão, pré-parto, parto e pós-parto imediato e interpretar os aspectos facilitadores e dificultadores de sua inserção nos serviços de atenção maternal. Trata-se de uma pesquisa qualitativa, desenvolvida com um grupo de enfermeiras obstétricas da cidade de Londrina-PR. A coleta de dados foi desenvolvida no mês de dezembro de 2015 através das seguintes etapas: 1. Entrevista individual e semiestruturada com 20 enfermeiras obstétricas, tendo como critério de seleção a atuação nos serviços de atenção materna, nos setores de admissão, pré-parto, parto e pós-parto imediato por pelo menos um ano; 2. Aplicação da metodologia Photovoice com a participação de 10 enfermeiras obstétricas, pretendendo compreender as fragilidades e potencialidades encontradas em sua prática assistencial. Nesta fase, as enfermeiras obstétricas produziram e apresentaram as fotografias em um grupo focal para discussão, gerando os temas de análise, que, em conjunto com os dados obtidos nas entrevistas individuais, formaram a base teórica que possibilitou alcançar os objetivos propostos no estudo. $\mathrm{O}$ referencial teórico adotado foi a antropologia interpretativa, com o enfoque na cultura das organizações, que permitiu a análise e compreensão dos dados. Os resultados foram descritos e analisados em torno de cinco categorias temáticas, das quais as três iniciais emergiram das entrevistas iniciais e as outras duas do grupo focal com a metodologia Photovoice, a saber: Acolhimento e vínculo: cuidados assistenciais que transmitem segurança à parturiente; Autonomia na enfermagem obstétrica: percepções da prática assistencial; Sentimentos emanados na atenção da enfermeira obstétrica nos cenários da admissão, pré-parto, parto e pós-parto imediato; Fatores facilitadores na assistência da enfermeira obstétrica: potencialidades emanadas nos cenários de admissão, préparto, parto e pós-parto imediato; Fatores dificultadores na assistência da enfermeira obstétrica: fragilidades afloradas nos cenários de admissão, pré-parto, parto e pós-parto imediato. A situação encontrada é a de desprivilégio da assistência obstétrica: em quase todas 
as instituições prevalece ainda o modelo biomédico, concentrado em intervenções e com poucas ações de humanização. Mesmo quando as enfermeiras obstétricas estão inseridas na assistência, elas encontram obstáculos para o desenvolvimento de sua prática assistencial, tanto pela equipe multiprofissional em que estão inseridas quanto pelas organizações onde atuam. Foram apontados como facilitadores/potencialidades $\mathrm{o}$ estabelecimento do planejamento familiar, a humanização na assistência ao parto, o trabalho em equipe, a educação continuada e permanente, a autonomia, a infraestrutura adequada. Já como pontos fragilidades/dificuldades, a ausência de pré-natal completo, a falta de realização de partos nas maternidades onde atuam, a ausência ou demora no estabelecimento do contato precoce mãe e filho, a falta de informatização nos processos burocráticos, a violência obstétrica e a falta de estrutura adequada. Por fim, considera-se que os resultados apontaram para uma realidade cultural que não pode ficar omissa. As enfermeiras obstétricas são profissionais capacitadas para atuarem na humanização da assistência e contribuírem para a redução de índices de morbimortalidade materna em nosso país. Logo, os achados deste estudo podem fomentar ações e mudanças nas organizações de saúde.

Descritores: Enfermagem Obstétrica, Photovoice, Estudo qualitativo, Saúde da mulher. 


\begin{abstract}
ESSER, M. A. M. S. Performance of midwife: understanding their experience and the reality of assistance. 2016. 224F. Thesis (Doctor in Science) - School of Nursing, University of São Paulo. Ribeirao Preto, 2016.
\end{abstract}

Many worldwide efforts have been employed to improve health conditions during pregnancy and birth. Each year, approximately 350,000 women die during pregnancy or childbirth, and 99\% of these deaths occur in developing countries. The Ministry of Health has been developing actions to improve the framework for maternal care, promoting activities to qualify professionals and foster obstetric and neonatal care humanized based on scientific evidence, and ensure sexual and reproductive rights of Brazilian women. The setting is found marginalization of midwifery, midwife has difficulty in acting, both in performing obstetrical consultations and in monitoring the labor and birth. His practice shown underprivileged power because there is no recognition of their professional qualifications. This study aims to understand the experience of midwife at the admission stage, pre-natal, delivery and immediate postpartum period and interpret the advantages and constraints of their inclusion in the maternal care services. This is a qualitative research conducted with a group of midwives in the city of Londrina. Data collection was developed in December 2015 through the following steps: 1. Individual interview and semi-structured interviews with 20 midwives, with the selection criteria acting in maternal care services, the admission sectors, pre- labor, delivery and immediate postpartum period for at least 1 year; 2. Photovoice Methodology application with the participation of 10 midwives, intending to understand the weaknesses and strengths found in their care practice. At this stage, midwife produced and presented the photos in a focus group for discussion, generating the analysis of topics, together with the data obtained in individual interviews formed the theoretical basis which allowed achieve the objectives proposed in the study. The theoretical framework adopted was the interpretive anthropology, with a focus on culture of organizations, which allowed the analysis and understanding of the data. The results were described and analyzed around five thematic categories, the first three emerged from the initial interviews and the other two focus group with Photovoice methodology, namely: Reception and attachment: supportive care that transmit security to the woman in labor; Autonomy in midwifery: perceptions of nursing practice; Feelings emanating from the care of the midwife in the admission of scenarios, antepartum, delivery and immediate postpartum; Factors facilitators in the midwife assistance: emanating potential in admission scenarios, antepartum, delivery and immediate postpartum; Hindering factors in midwife care: weaknesses touched upon the admission of scenarios, antepartum, delivery and immediate postpartum. The situation found is the marginalization of obstetric care in almost all institutions still prevails the biomedical model, focused on interventions and few humanizing actions, even when midwives are placed in care, they are obstacles to the development of its care practice, both by the multidisciplinary team where they are inserted as the organizations where they work. Were appointed as facilitators / potential establishment of family planning, the humanization of childbirth care, teamwork, continuous and permanent education, autonomy, adequate infrastructure. Already as points weaknesses / difficulties the absence of complete prenatal care, the lack of completion of deliveries in hospitals where they operate, the absence or delay in early contact establishment mother and child, the lack of computerization in bureaucratic processes, obstetric violence 
and lack of adequate structure. Finally, it is considered that the results pointed to a cultural reality that cannot be silent. Midwife are professionals trained to work in the humanization of care and contribute to the reduction of maternal morbidity and mortality rates in our country. Thus, the findings of this study can foster action and change in healthcare organizations.

Keywords: Obstetric, Photovoice, Qualitative Study, Women's Health 


\section{RESUMEN}

Esser, M. A. M. S. El rendimiento de la enfermera obstétrica: la comprensión de su experiencia y la realidad de la asistencia. 2016. 224F. Tesis (Doctorado) - Ribeirao Preto Escuela de Enfermería, Universidad de Sao Paulo. Ribeirao Preto, 2016.

Se han empleado muchos esfuerzos internacionales para mejorar las condiciones de salud durante el embarazo y el parto. Cada año, aproximadamente 350.000 mujeres mueren durante el embarazo o el parto, y el $99 \%$ de estas muertes se producen en países en desarrollo. El Ministerio de Salud ha venido desarrollando acciones para mejorar el marco de la asistencia materna, la promoción de actividades para capacitar a los profesionales y fomentar la atención obstétrica y neonatal humanizada basada en la evidencia científica, y garantizar los derechos sexuales y reproductivos de las mujeres brasileñas. La configuración se encuentra marginación de la obstetricia, enfermera obstétrica tiene dificultad en la actuación, tanto en la realización de consultas obstétricas y en la supervisión del trabajo de parto y el nacimiento. $\mathrm{Su}$ práctica se muestra el poder desfavorecidos porque no hay reconocimiento de sus cualificaciones profesionales. Este estudio tiene como objetivo comprender la experiencia de la enfermera obstétrica en el período de la etapa de admisión, pre-natal, parto y posparto inmediato e interpretar las ventajas y limitaciones de su inclusión en los servicios de atención materna. Se trata de una investigación cualitativa llevada a cabo con un grupo de parteras en la ciudad de Londrina. La recolección de datos se desarrolló en diciembre de 2015, a través de los siguientes pasos: 1. Entrevista individual y entrevistas semiestructuradas con 20 parteras, con los criterios de selección que actúan en los servicios de atención materna, los sectores de admisión, pre el parto y posparto inmediato durante al menos 1 año; 2. Metodología de aplicación Fotovoz con la participación de 10 parteras, con la intención de comprender los puntos fuertes y débiles que se encuentran en la práctica asistencial. En esta etapa, las enfermeras obstétricas producen y presentan las fotos en un grupo focal para la discusión, generando el análisis de los temas, junto con los datos obtenidos en las entrevistas individuales fueron la base teórica que permitió alcanzar los objetivos propuestos en el estudio. El marco teórico adoptado fue la antropología interpretativa, con un enfoque en la cultura de las organizaciones, lo que permitió el análisis y la comprensión de los datos. Los resultados se describen y analizan en torno a cinco categorías temáticas, los tres primeros surgieron de las entrevistas iniciales y el otro grupo dos se centran con la metodología fotovoz, a saber: Recepción y apego: la atención de apoyo que transmiten seguridad a la parturienta; Autonomía en obstetricia: percepciones de la práctica de enfermería; Los sentimientos que emanan de la atención de la partera en la admisión de los escenarios, antes del parto, parto y posparto inmediato; Factores facilitadores de la asistencia partera: emana potenciales en escenarios de admisión, antes del parto, parto y posparto inmediato; Los factores obstaculizadores en el cuidado de enfermería obstétrica: debilidades se refirieron a la admisión de los escenarios, antes del parto, parto y posparto inmediato. La situación encontrada es la marginación de la atención obstétrica en casi todas las instituciones aún prevalece el modelo biomédico, se centró en las intervenciones y las pocas acciones de humanización, incluso cuando las parteras están colocadas fuera del hogar, que son un obstáculo para el desarrollo de su la práctica asistencial, tanto por el equipo multidisciplinario en el que se insertan como las organizaciones en las que trabajan. Fueron designados como 
facilitadores / potencial de establecimiento de la planificación familiar, la humanización de la atención del parto, trabajo en equipo, la educación continua y permanente, la autonomía, la infraestructura adecuada. Ya como puntos débiles / dificultades la falta de atención prenatal completa, la falta de realización de las entregas en los hospitales en los que operan, la ausencia o retraso en el establecimiento de contactos de la madre y el niño precoz, la falta de informatización de los procesos burocráticos, violencia obstétrica y falta de estructura adecuada. Por último, se considera que los resultados apuntan a una realidad cultural que no puede estar en silencio. enfermeras obstétricas son profesionales capacitados para trabajar en la humanización de la atención y contribuir a la reducción de las tasas de morbilidad y mortalidad materna en nuestro país. Por lo tanto, los resultados de este estudio pueden fomentar la acción y el cambio en las organizaciones sanitarias.

Palabras clave: Enfermería Obstétrica, Fotovoz, Estudio Cualitativo, Salud de la Mujer. 


\section{LISTA DE ILUSTRAÇÕES}

Figura 1 - Fotografia selecionada pela Enfermeira Obstétrica Beatriz

Figura 2 - Fotografia produzida pela Enfermeira Obstétrica Cleo

Figura 3 - Fotografia produzida pela Enfermeira Obstétrica Beatriz

Figura 4 - Fotografia produzida pela Enfermeira Obstétrica Maria

Figura 5 - Fotografia produzida pela Enfermeira Obstétrica Carolina

Figura 6 - Fotografia produzida pela Enfermeira Obstétrica Eva

Figura 7 - Fotografia produzida pela Enfermeira Obstétrica Rose

Figura 8 - Fotografia selecionada pela Enfermeira Obstétrica Beatriz

Figura 9 - Fotografia produzida pela Enfermeira Obstétrica Beatriz

Figura 10 -Fotografia produzida pela Enfermeira Obstétrica Rose

Figura 11 - Fotografia produzida pela Enfermeira Obstétrica Luiza

Figura 12 - Fotografia selecionada pela Enfermeira Obstétrica Gisele

Figura 13 - Fotografia selecionada pela Enfermeira Obstétrica Beatriz

Figura 14 - Fotografia produzida pela Enfermeira Obstétrica Rose

Figura 15 - Fotografia produzida pela Enfermeira Obstétrica Gabriela

Figura 16 - Fotografia produzida pela Enfermeira Obstétrica Beatriz

Figura 17 - Fotografia produzida pela Enfermeira Obstétrica Maria

Figura 18 - Fotografia produzida pela Enfermeira Obstétrica Maria

Figura 19 - Fotografia produzida pela Enfermeira Obstétrica Clara

Figura 20 - Fotografia produzida pela Enfermeira Obstétrica Beatriz

Figura 21 - Fotografia produzida pela Enfermeira Obstétrica Beatriz 163

Figura 22 - Fotografia produzida pela Enfermeira Obstétrica Clara 
Figura 23 - Fotografia produzida pela Enfermeira Obstétrica Eva

Figura 24 - Fotografia produzida pela Enfermeira Obstétrica Beatriz

Figura 25 - Fotografia produzida pela Enfermeira Obstétrica Maria

Figura 26 - Fotografia produzida pela Enfermeira Obstétrica Eva

Figura 27- Fotografia produzida pela Enfermeira Obstétrica Gisele 173

Figura 28 - Fotografia produzida pela Enfermeira Obstétrica Luiza 176

Figura 29- Fotografia produzida pela Enfermeira Obstétrica Rose. 180

Figura 30 - Fotografia produzida pela Enfermeira Obstétrica Gabriela 181

Figura 31 - Fotografia produzida pela Enfermeira Obstétrica Gisele 182

Figura 32 - Fotografia produzida pela Enfermeira Obstétrica Gabriela 186 


\section{LISTA DE ABREVIAÇÕES E SIGLAS}

AIH - Autorização para Internação Hospitalar

ANVISA - Agência Nacional de Vigilância Sanitária

ASMS - Autarquia do Serviço Municipal de Saúde

COREN-RJ - Conselho Regional de Enfermagem do Rio de Janeiro

CPN - Centro de Parto Normal

CREMERJ - Conselho Regional de Medicina do Rio de Janeiro

CTG - Cardiotocografia

EERP/USP - Escola de Enfermagem de Ribeirão Preto/Universidade de São Paulo

IBGE - Instituto Brasileiro de Geografia e Estatística

MATER - Maternidade do Complexo Aeroporto

MEC - Ministério da Educação

MS - Ministério da Saúde

ODM - Objetivos de Desenvolvimento do Milênio

OMS - Organização Mundial de Saúde

OPAS - Organização Panamericana de Saúde

PHPN - Política de Humanização do Parto e Nascimento

PPP - Pré-Parto - Parto - Puerpério

RDC - Resolução da Diretoria Colegiada

SAMU - Serviço de Atendimento Móvel de Urgência

SIATE - Serviço Integrado de Atendimento ao Trauma em Emergência

SSVV - Sinais Vitais

SUS - Sistema Único de Saúde 
TCLE - Termo de Consentimento Livre e Esclarecido UNICEF - Fundo das Nações Unidas para a Infância USG - Ultrassonografia 


\section{SUMÁRIO}

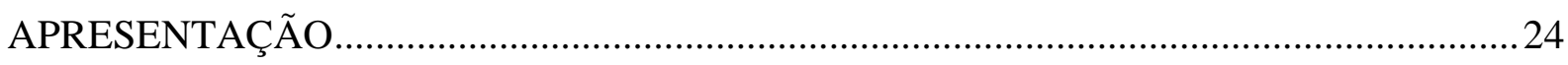

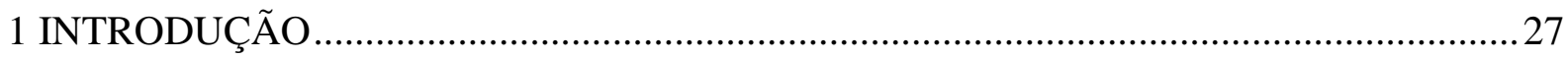

2 CONTEXTUALIZANDO O OBJETO DA INVESTIGAÇÃO: ASSISTÊNCIA AO

PARTO E A ENFERMAGEM OBSTÉTRICA BRASILEIRA ………………………….........

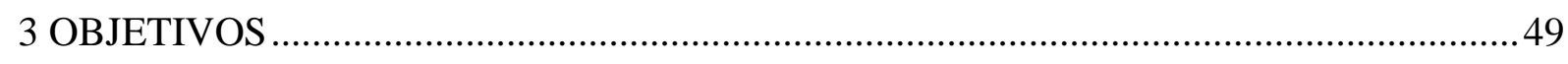

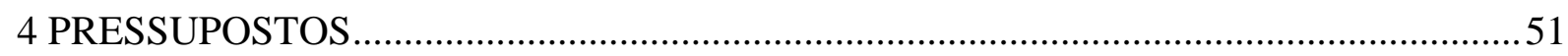

5 REFERENCIAL TEÓRICO: ABORDAGEM ANTROPOLÓGICA NA ATUAÇÃO DA ENFERMEIRA OBSTÉTRICA NA ASSISTÊNCIA AO PARTO_..........................................53

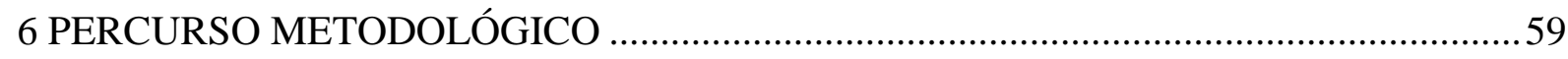

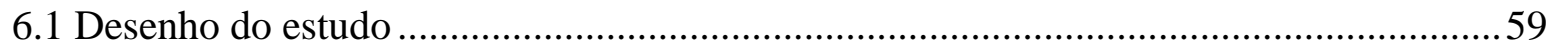

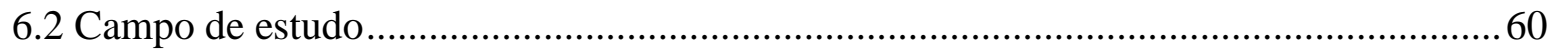

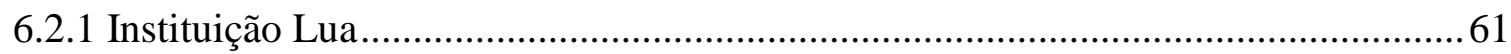

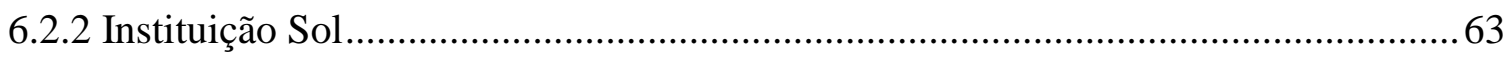

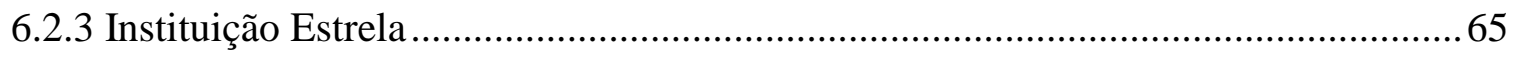

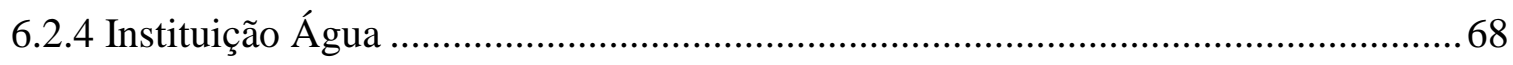

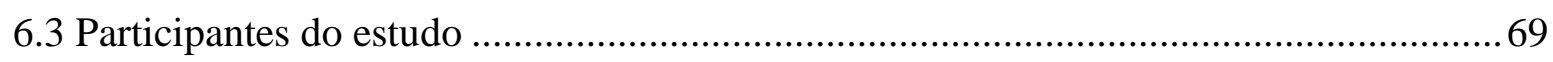

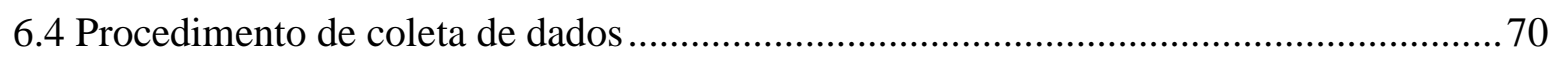

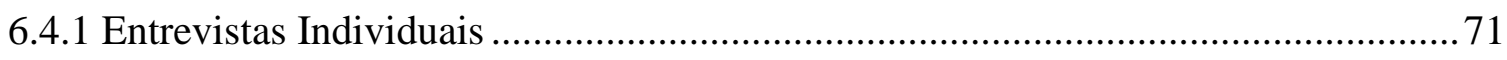

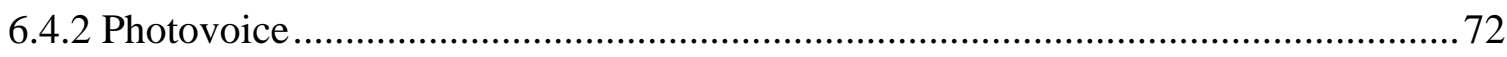

6.4.2.1 Conectando e consultando a comunidade …………………….................... 75

6.4.2.2 Planejando o Photovoice ...................................................................... 76

6.4.2.3 Recrutando os participantes e público-alvo ……………………………..... 76

6.4.2.4 Iniciando o Photovoice ………………………….........................................

6.4.2.5 Encontros grupais do Photovoice............................................................. 78 


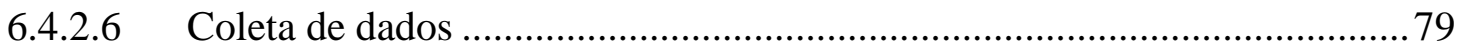

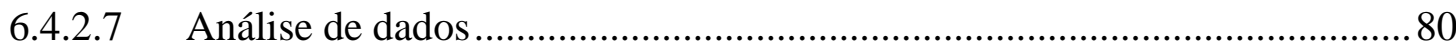

6.4.2.8 Preparando e compartilhando a exposição do Photovoice ........................... 81

6.4.2.9 Ação social e mudanças nas políticas ........................................................ 82

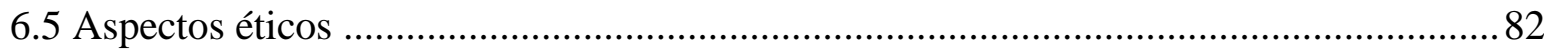

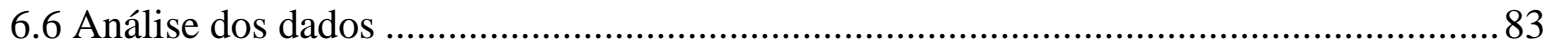

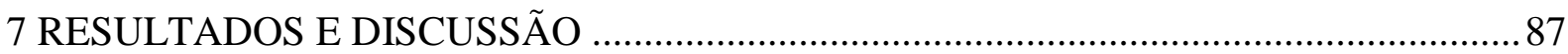

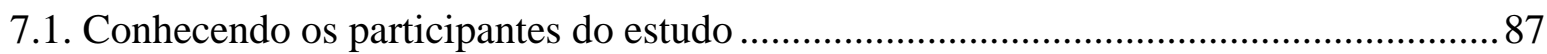

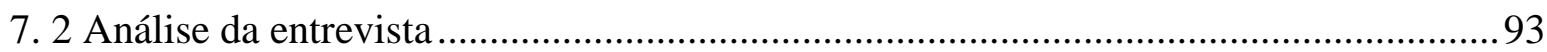

7.2.1 O significado da assistência da enfermeira obstétrica no cenário da admissão, pré-

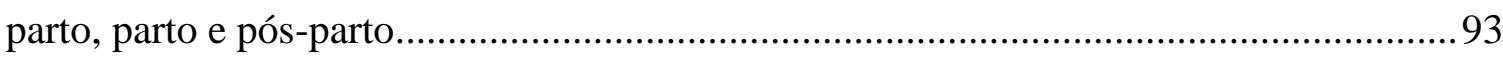

7.2.1.1 Acolhimento e vínculo: cuidados assistenciais que transmitem segurança à parturiente

7.2.1.2 Autonomia na enfermagem obstétrica: percepções da prática assistencial .... 105

7.2.1.3 Sentimentos emanados na atuação da enfermeira obstétrica nos cenários da admissão, pré-parto, parto e pós-parto imediato......................................................... 111

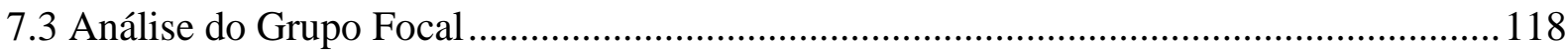

7.3.1 Fatores facilitadores na assistência da enfermeira obstétrica: potencialidades emanadas nos cenários da admissão, pré-parto, parto e pós-parto imediato

7.3.2 Fatores dificultadores na assistência da enfermeira obstétrica: fragilidades afloradas nos cenários de admissão, pré-parto, parto e pós-parto imediato

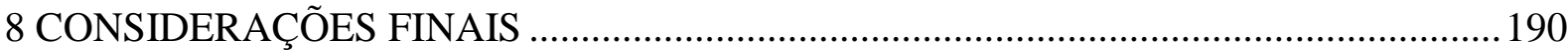

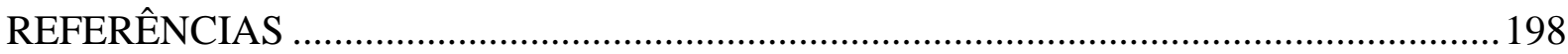

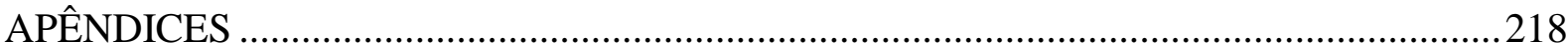

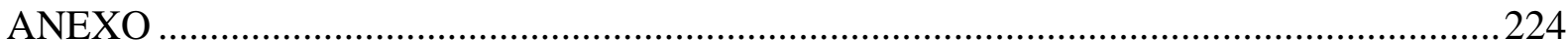


APRESENTAÇÃO 


\section{APRESENTAÇÃO}

Minha atuação na área da Saúde da Mulher iniciou-se há 16 anos enquanto estudante do $3^{\circ}$ ano do curso de Enfermagem da Universidade Estadual de Londrina. Fiquei encantada com o processo de parturição e, ao mesmo tempo, decepcionada de como este momento mágico estava envolto por muitos procedimentos e burocracia.

O que ficou marcado para mim foi o fato de trabalharmos com a humanização da assistência na academia e não encontrar este olhar na atuação da equipe de enfermagem, não ficando evidenciado o papel da enfermeira naquele cenário.

Comecei a indagar o que era necessário fazer para transformar o momento mágico do nascimento em uma cena humanizada, da qual a parturiente se recordasse como algo positivo, que valeu a pena, não apenas como sinônimo de dor e sofrimento.

Meu caminho na enfermagem obstétrica iniciou-se assim quando me formei, ao ingressar na Residência em Enfermagem Obstétrica da Escola de Enfermagem de Ribeirão Preto - USP (EERP/USP), onde consegui aprender, passo a passo, o modelo ideal da assistência de enfermagem obstétrica mesmo estagiando na Maternidade do Complexo Aeroporto (MATER), baseada em um modelo intervencionista. Vivenciei a implantação de muitas mudanças assistenciais, de modo a garantir as práticas de humanização na assistência de enfermagem obstétrica e na adoção da inserção da enfermeira obstétrica em todas as áreas da maternidade.

Ainda enquanto residente, desenvolvi a monografia sob orientação da Profa. Dra. Marli Villela Mamede, traçando o perfil dos partos assistidos pelas enfermeiras 
residentes na MATER em anos anteriores, tendo como resultado a prática sistemática de ações de humanização e ausência de complicações.

Após o término da residência, retornei a Londrina-PR, iniciei minha trajetória profissional trabalhando em duas maternidades privadas e pude perceber como a realidade encontrada estava muito distante dos ensinamentos aprendidos na EERP/USP. Comecei a minha carreira como docente na área de saúde da mulher do curso de Enfermagem na Universidade Estadual de Londrina, o que logo me despertou o interesse pelo Mestrado.

Meus estudos no mestrado se iniciaram em 2008, na EERP/USP, sob orientação da Profa. Dra. Fabiana Villela Mamede, que me conduziu na pesquisa sobre a atenção qualificada à mulher no parto nas maternidades de Londrina-PR. Essa pesquisa evidenciou que a assistência prestada pela equipe de enfermagem nas maternidades necessitava de protocolos assistenciais e que, em apenas uma instituição, a enfermeira obstétrica realizava partos, mesmo que de forma modesta. Percebemos que muitas habilidades essenciais para a atenção qualificada ao parto não estavam sendo desempenhadas de forma completa.

Conduzida por esta inquietação e por acreditar na necessidade de aprofundar os estudos sobre a inserção das enfermeiras obstétricas no cenário do pré-parto, parto e pósparto imediato, iniciei esta pesquisa de Doutorado na EERP/USP, sob orientação da Profa. Dra. Fabiana Villela Mamede, buscando encontrar os fatores facilitadores e dificultadores da inserção das enfermeiras obstétricas nas maternidades de Londrina-PR, rastreando os aspectos profissionais e culturais envolvidos nessas questões. 
INTRODUÇÃO 


\section{INTRODUÇÃO}

A cada ano, aproximadamente 350 mil mulheres morrem durante a gravidez ou parto, sendo que $99 \%$ dessas mortes acontecem em países em desenvolvimento. Há uma estimativa de que oito milhões dessas mulheres sofrem sequelas com repercussões ao longo de suas vidas resultantes de complicações durante o parto (UNFPA, 2011).

Além disso, cerca de dois milhões de recém-nascidos morrem nas primeiras 24 horas de vida e 2,6 milhões configuram-se como natimortos, $45 \%$ das quais ocorrem no parto e nascimento. Outrossim, milhares de recém-nascidos sofrem traumas no nascimento, o que prejudica o desenvolvimento e a produtividade futura (UNFPA, 2011).

Os desafios para alcançar o quinto objetivo de desenvolvimento do milênio, ou seja, melhoria da saúde da gestante, tornaram-se globais para garantir o direito das mulheres a melhores cuidados de saúde possíveis durante a gravidez e o parto. O Brasil deve desenvolver ações que diminuam a mortalidade materna em três quartos, garantindo assim o acesso universal à saúde reprodutiva de qualidade (WHO, 2010).

No que se refere aos dados estatísticos em nosso país, para garantir o alcance deste quinto objetivo, a Razão de Mortalidade Materna deverá ser reduzida a 35 óbitos de mulheres a cada 100.000 nascidos vivos. Esse índice apresentou declínio de 140 mortes maternas em 1990 para 75 em 2007 e, em 2010, encontrou-se em 67,5, não se observando uma diminuição significativa, já que a meta para o período era estimada em 56. (PAHO, 2012). Isso nos leva a acreditar na necessidade de mudanças na atenção obstétrica, 
para que o país consiga melhorar o indicador e a assistência prestada às mulheres no ciclo gravídico puerperal.

O Ministério da Saúde (MS) vem desenvolvendo ações no sentido de melhorar o quadro da assistência materna, promovendo atividades para qualificar os profissionais e fomentar a atenção obstétrica e neonatal humanizada baseada em evidências científicas, além de garantir os direitos sexuais e reprodutivos das mulheres brasileiras (NARCHI et al., 2013; RATTNER, 2009).

As medidas para redução da mortalidade materna adotadas pelo MS incluem ações e programas como Maternidade Segura, Humanização do Pré-natal e Nascimento, Pacto Nacional pela Redução da Mortalidade Materna e Neonatal, Política Nacional de Atenção Integral à Saúde da Mulher, Lei do Acompanhante, Plano de Qualificação de Maternidades e Redes Perinatais, e, recentemente, o Projeto Rede Cegonha (BRASIL, 2010a).

A Rede Cegonha é uma rede de cuidados que assegura às mulheres o direito ao planejamento reprodutivo, à atenção humanizada à gravidez, parto, abortamento e puerpério e às crianças, o direito ao nascimento seguro, crescimento e desenvolvimento saudáveis. Tem como objetivo principal ser um novo modelo de atenção ao parto, nascimento e à saúde da criança, apresentando uma rede de atenção que garanta acesso, acolhimento e resolutividade e redução da mortalidade materna e neonatal (BRASIL, 2011a).

Conforme a Portaria n ${ }^{\circ}$ 1459, de 24 de Junho de 2011, a Rede Cegonha tem como diretrizes principais o acolhimento com classificação de risco, ampliação do acesso e melhoria da qualidade pré-natal, garantindo à mulher o acesso e vinculação da gestante à unidade de referência, utilizando transporte seguro. Neste sentido, há também a garantia de a 
assistência prestada ser pautada por boas práticas e de o atendimento ser realizado de forma segura (BRASIL, 2011a).

De acordo com a Portaria $\mathrm{n}^{\circ} 2351$, de 5 de outubro de 2011, o MS vai fornecer aporte financeiro para garantir melhorias estruturais, com a construção de Centros de Partos Normais, reforma nas instalações existentes, aquisição de equipamentos e materiais, construção de casas de gestantes, bebê e puérpera (BRASIL, 2011b).

Embora somente essas ações não tenham demonstrado melhoria na qualidade da assistência prestada à mulher grávida, há ainda muito que melhorar para garantir avanços e diminuir os índices de mortalidade materna e neonatal (RATTNER, 2009).

Algumas alternativas estão sendo propostas por várias instituições de saúde integradas ao Sistema Único de Saúde, as quais organizaram a assistência ao parto normal de baixo risco com base no modelo de Centro de Parto Normal Intra-hospitalar, com o objetivo de possibilitar a presença rotineira do acompanhante e de prestar o cuidado individualizado, onde a assistência é realizada por enfermeiras obstétricas em trabalho colaborativo com médicos obstetras e neonatologistas, seguindo as recomendações da Organização Mundial de Saúde (OMS), que reforçam o fornecimento do respaldo legal e normativo para a participação dos profissionais não médicos na melhoria da atenção à maternidade (WHO, 2004).

A despeito de existirem políticas públicas para inserção da enfermeira obstétrica na atenção ao parto e nascimento, o cenário observado na prática é que a assistência ao parto continua medicalizada, não se respeitando a fisiologia e a evolução natural do nascimento. Os ambientes são desfavoráveis, com pouca privacidade e sem apoio aos 
familiares. Desta forma, a assistência prestada permanece longe do ideal e seguro para a melhoria no índice de morbimortalidade materna e neonatal.

Mesmo quando a enfermeira obstétrica está inserida no contexto da atenção à saúde da mulher no período do parto, na maioria dos serviços hospitalares, suas atividades são desenvolvidas de forma tímida e burocrática, desempenhando poucas atividades assistenciais, o que segue sentido oposto ao preconizado pelo MS (ESSER et al., 2012).

Em resposta a esta realidade, em 2011, o MS, em conjunto com o MEC, lança o Programa Nacional de Residência em Enfermagem Obstétrica, com o objetivo de oferecer recursos humanos qualificados com base na proposta de mudança do modelo assistencial vigente, visando a um tratamento humanizado à mulher e sua família, e o reconhecimento dos direitos de cidadania e a abordagem de gênero na atenção à saúde tiveram por base o desempenho não adequado dos indicadores de saúde reprodutiva das mulheres assistidas no Sistema Único de Saúde/SUS (BRASIL, 2012a).

No exercício da docência, acompanhando atividades práticas de alunos de graduação, tenho observado por diversas vezes a falta de autonomia e visibilidade das enfermeiras obstétricas no desempenho de suas funções, revelando dificuldades de inserção desta profissional em um perfil estritamente assistencial. As ações dessas profissionais geralmente estão restritas a procedimentos administrativos enquanto as ações de humanização da assistência à mulher são colocadas em outro plano de prioridade, nem sempre executado, devido à falta de tempo e autonomia para tal.

O cenário encontrado é de marginalização da enfermagem obstétrica, prevalecendo o modelo biomédico, centrado em intervenções e procedimentos cirúrgicos. A 
enfermeira obstétrica apresenta dificuldades na atuação, tanto na realização de consultas obstétricas quanto no acompanhamento do parto e nascimento. Sua prática se mostra desprivilegiada de poder, pois não há reconhecimento da sua qualificação pela maioria da classe médica, o que reflete em pouco espaço para sua atuação na atenção à mulher e o exercício de suas atividades se limita, muitas vezes, apenas às administrativas e burocráticas.

O Conselho Regional de Medicina do Rio de Janeiro (CREMERJ) recentemente publicou resoluções (265 e 266/2012) proibindo a atuação de médicos, parteiras, obstetrizes e doulas na atenção ao parto domiciliar, deixando claro o abuso de poder da categoria, já que consideram o parto domiciliar como prática retrógrada e insegura. O CREMERJ também impôs fiscalização ao processo de trabalho da enfermeira, obrigando as equipes de emergência a notificarem o Conselho de Medicina quando em chamados oriundos das casas de parto (CREMERJ, 2012).

É importante ressaltar que essa medida não atingiu diretamente as enfermeiras obstétricas, mas o resultado dela foi a falta do trabalho multidisciplinar e a dificuldade de integralidade das atividades entre os diversos profissionais, sejam eles médicos obstetras e neonatologistas, enfermeiras obstétricas e demais profissionais.

Tal atitude gerou protestos por parte de profissionais e Organizações não governamentais que representam mulheres a favor da humanização do parto e nascimento, além de acionamento judicial pelo Conselho Regional de Enfermagem do Rio de Janeiro, que levou a Justiça a suspender as resoluções do CREMERJ por entender que elas ofendiam diversos dispositivos constitucionais e legais de direitos das mulheres. $\mathrm{O}$ assunto transbordou nas redes sociais e nas páginas e publicações da classe médica, inclusive com notícias falsas, 
o que denegriu e desqualificou a assistência prestada pelas enfermeiras obstétricas (ZVEITER; SOUZA, 2015).

Neste sentido, destaca-se que, mesmo quando as enfermeiras obstétricas estão inseridas na assistência, elas encontram barreiras para o desenvolvimento de ações assistenciais e, muitas vezes, deficiências nas dimensões do saber-saber e o saber-fazer em obstetrícia. Por vezes, são submetidas à pressão institucional para manutenção do modelo assistencial e, algumas vezes, utilizam práticas desaconselhadas e sem evidências científicas na atenção obstétrica, fazendo prevalecer o modelo centrado no profissional médico, constituído de excesso de práticas intervencionistas na assistência ao parto e nascimento.

Desta forma, tal modelo contraria o preconizado pela OMS, segundo o qual o objetivo da assistência obstétrica dever ser a obtenção de mãe e criança saudáveis com o mínimo possível de intervenções, mantendo exclusivamente a segurança do binômio, havendo intervenções somente quando existir razão válida para interferência no processo natural de nascimento (ENKIN, 2005).

A formação da enfermeira obstétrica abrange habilidades e competências que viabilizam a assistência integral, prezando por um processo fisiológico de parir, transmitindo segurança e repercutindo de forma positiva na saúde materno-infantil (AMORIM; GUALDA, 1998). A formação destes profissionais visa representar modelos bem-sucedidos adotados por outros países, onde profissionais não-médicos são os fornecedores de saúde na rede primária de mulheres saudáveis durante o parto (ALMEIDA et al., 2012). 
Neste sentido, constata-se que a atuação da enfermeira obstétrica é fundamental e estratégica, pois atua de forma qualificada, contribuindo para a melhoria da saúde materna e para a conquista do quinto objetivo de desenvolvimento do milênio, por atuarem isentas de intervenções obstétricas e com uso adequado de tecnologia, respeitando o parto centrado na fisiologia e nas necessidades e escolhas das mulheres (REIS et al., 2015).

Na intenção de melhor compreender a realidade da prática das enfermeiras obstétricas no exercício de suas funções de assistir as mulheres em processo de concepção, elegi os seguintes questionamentos para direcionar o desenvolvimento desta pesquisa: Como as enfermeiras obstétricas percebem a sua inserção e sua atuação no contexto de atenção ao parto e quais fatores contribuem positivamente e negativamente para o exercício de sua função?

Diante desses questionamentos, propusemos realizar esta pesquisa com a finalidade de compreender as vivências da enfermeira obstétrica na atenção materna e desvelar medidas facilitadoras e dificultadoras do exercício de suas atividades, sob a ótica delas mesmas.

Este estudo se justifica visto que seu desenvolvimento poderá colaborar com a condução de políticas de atenção obstétrica à medida que seus achados venham sinalizar indicadores para a inserção da enfermeira obstétrica na atenção ao pré-parto, parto e pós-parto imediato, consequentemente, para mudança do modelo assistencial, com a redução de intervenções desnecessárias e o fortalecimento da humanização da assistência. 
CONTEXTUALIZANDO O OBJETO DA INVESTIGAÇÃO:

ASSISTÊNCIA AO PARTO E A ENFERMAGEM OBSTÉTRICA BRASILEIRA 


\section{CONTEXTUALIZANDO O OBJETO DA INVESTIGAÇÃO: ASSISTÊNCIA AO PARTO E A ENFERMAGEM OBSTÉTRICA BRASILEIRA}

Para compreender o universo deste estudo, faz-se necessário contextualizar a assistência ao parto e a inserção da enfermagem obstétrica em nosso país, o que auxiliará no subsídio teórico deste estudo. Nesta parte apresentaremos os acontecimentos relevantes no que diz respeito ao histórico da assistência às mulheres durante o trabalho de parto e parto, bem como o surgimento da profissão e sua forma de atuação nas maternidades brasileiras.

Para Progiante e Barreira (2001), o ato de parir sempre foi conotado como um evento solitário. Com o desenvolvimento da sociedade, no entanto, surgiu a arte de partejar como um fenômeno desenvolvido por mulheres mais velhas, que tinham a experiência da parturição e utilizavam a experiência dos próprios partos para ajudar outras no momento dos nascimentos. Este saber acumulado pelas parteiras constituiu a obstetrícia empírica.

O parto é historicamente um evento natural, considerado fato mobilizador e marcante na vida da mulher. Mesmo as primeiras civilizações atribuíram a este acontecimento inúmeros significados culturais, que sofreram transformações através das gerações. A experiência do parto varia amplamente de uma cultura para outra. Toda sociedade possui regras que controlam o nascimento, especificando o local de sua ocorrência, determinando quem atende a parturiente e indicando comportamentos a serem adotados durante o trabalho de parto (GUALDA, 1998). 
Para entender o processo de parturição, é preciso considerar os contextos sociais, culturais e a individualidade físico-psicológica da parturiente, os quais influenciam na maneira como ela interpreta e sente as diferentes sensações físicas do trabalho de parto. Dessa forma, dar à luz não é simplesmente um ato fisiológico. O parto representa um fenômeno sociocultural porque redefine a identidade da mulher e afeta suas relações com os grupos com quem mantém contato, além de ocorrer num contexto em que estão incluídos os valores, as crenças, as práticas, os cuidados e o seu próprio significado de ser mulher/mãe (GUALDA, 1998).

Nas mais diferentes culturas, as vivências do parto foram de caráter íntimo e privado, sendo uma experiência compartilhada entre mulheres. A assistência obstétrica do século XVI ao XIX era atribuída às parteiras, "comadres” ou “curiosas", e o acesso ao quarto da parturiente era oculto, sendo proibida, por ordem moral, a entrada de homens em seus aposentos. Havia uma grande variedade de talismãs, orações e receitas mágicas para aliviar a dor das contrações e a mulher era auxiliada por mulheres, geralmente idosas, que, junto com as parteiras, acompanhavam todo o trabalho de parto. No entanto, já no final do século XIV, médicos e teólogos passaram a questionar as práticas das mulheres quanto ao uso de poções e cuidados em relação à gravidez, ao parto e ao puerpério (BRASIL, 2001; GUALDA, 1998; OSAVA, 1997; OSAVA, 1990).

Nas ocasiões em que a parteira ficava diante de um caso complicado, ela procurava primeiro reconhecer o que estava acontecendo, para, em seguida, sair em busca de outra parteira mais experiente. Apenas em último caso, ela buscava auxílio de um cirurgião. Desse modo, a presença de um cirurgião no parto era vivenciada com ansiedade pela mulher, pois indicava a gravidade da situação (OSAVA, 1990). Assim, gradualmente, entre os séculos 
XVI e XVII, começou a surgir, na assistência ao parto, a figura do cirurgião, e a parteira foi perdendo a primazia e o seu espaço.

No ensino médico, a obstetrícia surge como especialidade em 1806, incorporando um conjunto de práticas tocológicas, apesar de ter sua origem no conhecimento adquirido pelas parteiras. Ainda no século XVII, a participação masculina no parto era pouco frequente, justificando o relativo atraso da tocologia médica quando comparado ao desenvolvimento da medicina como um todo. A medicina moderna nasceu sob a tutela cirúrgica, e os primeiros cirurgiões que atendiam ao parto estavam mais focalizados na hemostase, na sutura e na drenagem, fato que retardou o desenvolvimento de um saber voltado às particularidades da gestação e do parto (OSAVA, 1990).

Por outro lado, a profissão de parteira começou a sofrer um declínio ao final do século XVI, ocasião da invenção do fórceps obstétrico pelo cirurgião britânico Peter Chamberlen, que idealizou o primeiro instrumento em 1598. O "cuidar da parturiente", percebido como uma série de procedimentos ao pé-do-leito, ganhou uma expressão concreta com o fórceps. Tal instrumento permitia a visualização da luta do homem contra a natureza e a substituição do paradigma não-intervencionista pela ideia de parto como um ato controlado pelo homem (OSAVA; TANAKA, 1997; OSAVA, 1990).

Vale ressaltar também que, com a entrada do médico no quarto da parturiente, ocorreram várias mudanças no processo de assistir a parturiente e uma delas diz respeito à postura e à posição adotadas pela mulher durante o período de dilatação, expulsão ou mesmo dequitação, pois ela passa a permanecer deitada no leito até o nascimento do bebê. Há menos de três séculos, a maioria das mulheres de todas as raças e culturas adotava uma 
posição vertical durante o trabalho de parto e parto. Atribui-se a François Mauriceau, médico francês do século XVII, a maior influência na mudança da posição do parto de vertical para horizontal. Ele afirmava que a posição reclinada seria a mais confortável para a parturiente e para o profissional que assiste ao parto. A posição supina - deitada de costas - que no início foi usada apenas durante os períodos de expulsão e nascimento passou, posteriormente, a ser indicada também para a fase de dilatação cervical. O aumento do uso de fórceps e da prática das cirurgias, a partir do século XVIII, parece ter sido também importante fator na manutenção das posições reclinadas e de litotomia (SABATINO et al., 2000).

A obstetrícia, firmando-se como matéria médica, acompanhou a evolução e supervalorização da tecnologia, ocorrendo, então, as primeiras ações voltadas a disciplinar o nascimento. $\mathrm{O}$ parto, antigamente visto como acontecimento natural e fisiológico ocorrido na própria residência da mulher, acompanhado de familiares e sob os cuidados de parteiras, passou a ser compreendido como um "fenômeno médico" e, portanto, necessitando de intervenções. Neste momento o parto deixa de ser privado, íntimo e feminino, passando a ser vivido de maneira pública, com a presença de outros atores sociais (BRASIL, 2001; GUALDA, 1998; OSAVA, 1990).

Com a transferência do nascimento do domicílio para um local desconhecido e estranho como o hospital, ocorreram mudanças significativas desde o ambiente até o momento em que uma mulher dá à luz. Diante da entrada de outros profissionais em cena, com seus instrumentos e intervenções, desloca-se a atenção da mãe para o bebê, relegando a mulher ao papel de objeto no processo de parturição. Ao se estabelecer o foco de atenção em torno da segurança da mãe e da criança, privilegiaram-se os 
progressos tecnológicos, porém penalizaram-se alguns outros aspectos essenciais do nascimento (OSAVA, 1990; MALDONADO, 1997).

Apesar de a gravidez não ser doença, no hospital, a parturiente adquire a condição de paciente, perde o controle sobre seu próprio corpo, sua privacidade, individualidade e muitas vezes torna-se submissa à equipe. Com frequência vê-se diante de instrumentos e equipamentos, de pessoas ao seu redor que não sabem o seu nome, referem-se a ela como a paciente do pré-parto, ou o oligoâmnio do leito tal, rotulando-a com números e patologias, mantendo-a presa no leito, o que leva à sua despersonalização enquanto mulher e pessoa. Neste ambiente frio e ameaçador em que se encontra, é afastada do apoio emocional da família, ficando aos cuidados de profissionais estranhos que nunca viu antes (VILA, 2001; GUALDA, 1998; OSAVA, 1990; MALDONADO, 1997).

Toda a tecnologia colocada à disposição do processo de parturição não resultou em segurança e qualidade na assistência à mulher e passa a ser questionada em âmbito mundial. Frente a isto, organismos internacionais têm buscado resgatar o processo de parturição como um processo fisiológico, com menos intervenções, e ressaltar os aspectos mais naturais do processo. Movimentos em prol da humanização da assistência surgiram como resposta à necessidade de mudanças na forma como está organizada a assistência obstétrica.

A intensa medicalização sofrida pelo corpo feminino e a perda de sua autonomia, nas últimas décadas, refletem o poder que os profissionais de saúde exercem na transformação de eventos fisiológicos em processos intervencionistas e patológicos. Maldonado (1997) lembra que os movimentos que buscam o resgate da humanização do nascimento recusam-se a considerar a maternidade e o parto como doença. Para o autor, 
ambos representam fatos fisiológicos, normais e não devem ser medicalizados quando desnecessários. O que é mais científico, rápido, conveniente e asséptico para os profissionais de saúde pode não ser o mais agradável para a mulher, transformando o parto em uma experiência sofrida e traumatizante.

Portanto, ao longo dos anos, muitas mulheres foram beneficiadas pela assistência obstétrica exercida por profissionais não-médicos, profissionais com práticas obstétricas tradicionais, as parteiras. $\mathrm{O}$ avanço tecnológico trouxe melhoria na assistência prestada, porém a assistência obstétrica ideal permeia uma mistura destes modelos (LEPPERT, 1997).

No Brasil, a assistência ao parto permaneceu nas mãos das parteiras por todo o século XIX (OZAVA; TANAKA, 1997), partindo-se das mesmas premissas mundiais, utilizando práticas não invasivas e místicas para diminuir o sofrimento das mulheres no momento do parto e nascimento (SEIBERT et al., 2005).

Em meados de 1832, iniciou-se a formação de parteiras junto às escolas médicas. As parteiras eram diplomadas e necessitavam de autorização legal para exercer a obstetrícia. Tal medida representou, no Brasil, o primórdio do controle dos médicos sobre a atividade das parteiras. A legislação médica contemplava as atividades exercidas pelas parteiras, de forma a denominar os nomes dos cursos, o currículo e o título concedido parteira, enfermeira parteira, enfermeira especializada, obstetriz e enfermeira obstétrica (JORGE, 1975).

No final do século XIX, segundo Riesco e Tsunechiro (2002), as associações médicas começaram a cogitar que as parteiras deveriam ter formação de 
enfermagem, limitando a prática independente delas, restringindo e controlando o seu espaço, determinando a hierarquia para as enfermeiras no cenário da assistência hospitalar. Nesta época, a classe médica defendia a hospitalização do parto e a medicalização da assistência, incluindo rotinas intervencionistas e cirúrgicas, com o advento da episiotomia e o fórceps. A assistência passou a ter a figura masculina no parto, e as mulheres acreditavam na prática medicalizada e que o nascimento somente seria seguro se acontecesse no ambiente hospitalar. Esse movimento teve seu ápice na década de 70 (PROGIANTI et al., 2003).

Os eventos naturais e espontâneos do processo de parir e nascer foram tomados pelo advento e aprimoramento das cesarianas, de modo a medicalizar o seu processo a ponto de figurar a nossa assistência até a atualidade (HISLOP; ARBER, 2003)

A mulher passou de sujeito da cena do nascimento para ser objeto do processo do parto, levada a procedimentos desnecessários e desumanos. Para se obter o controle desse cenário, foi necessário retirar as mulheres do ambiente familiar e separá-las do convívio de seus entes, despersonalizando as pessoas que a assistiam no parto. Ao adentrar no ambiente hospitalar, a mulher é despida de sua individualidade, de sua autonomia e de sua sexualidade (OSAVA, 1997).

O cuidado à mulher passou por uma mudança cultural muito importante após a institucionalização do parto, pois a assistência prestada passou a ser realizada de forma coletiva ao invés de individualizada. A mulher deixou de ser a protagonista do processo de nascimento, pois antigamente o nascimento transcorria no ambiente familiar e era envolto por sentimentos e vínculos. Ela foi inserida em um modelo cheio de intervenções e procedimentos, deixando de lado seus significados e suas crenças, e em um local onde os 
vínculos foram transformados em meros contatos superficiais, revelando de forma acentuada a perda da autonomia da mulher neste processo.

A construção de um modelo "ideal" de humanização no momento do parto é um aspecto desafiador que vem fazendo parte da nossa prática e trajetória profissional, enquanto enfermeira obstétrica, mulher, mãe, e, sobretudo, ser humano.

A humanização do atendimento à mulher no ciclo gravídico-puerperal compreende um conjunto de práticas que visam à promoção do parto e nascimento saudáveis e à prevenção da morbimortalidade materna e perinatal. Deve-se evitar o excesso de intervenções e utilizar os recursos tecnológicos disponíveis de forma criteriosa. A humanização inclui o respeito ao processo fisiológico e dinâmico de cada nascimento (OMS, 1996).

Desse modo, a assistência hospitalar ao parto deve ser segura, garantindo, para cada mulher, os benefícios dos avanços científicos, mas, fundamentalmente, deve permitir e estimular o exercício da cidadania feminina, resgatando a autonomia da mulher no parto (BRASIL, 2001).

Para Marques (1993) o corpo feminino no processo de nascimento passou a ser visto como máquina, levando a medicina a banalizar os aspectos psicológicos, sociais e ambientais, gerado pelo modelo tecnocrático de assistência. Em conseguinte a esta situação, a assistência prestada pelas parteiras foi aos poucos se tornando uma opção apenas para as mulheres pobres. A partir de 1920, houve o declínio da parteira no cenário do parto, sendo ele agora praticado no cenário hospitalar e medicalizado (OSAVA, 1997). No que tange ao avanço tecnológico e à melhoria das práticas obstétricas nos tempos atuais, percebe-se que o 
preço destas mudanças foi a prática intervencionista, sistemática e desnecessária, pois houve um retrocesso no acompanhamento dos fenômenos fisiológicos, atuando-se, na maioria das vezes, no sentido de intervir e resolver casos complicados. Com o controle médico, as mulheres passaram a ser submetidas a sondas, lavagens, toques vaginas, analgesia, episiotomias, controle e constrangimentos (MACHADO, 1998; OSAVA, 1997).

Diante deste cenário, a humanização da assistência ao parto e nascimento passou a ser uma preocupação mundial. A partir da década de 80, a OMS e Organização Panamericana de Saúde (OPAS) realizaram avaliações científicas a fim de buscar evidências de eficácia e segurança em assistir ao parto respeitando o processo fisiológico, voltado às necessidades da mulher e com o mínimo de intervenção possível; a síntese dessa avaliação foi publicada em 1996. A OMS estabeleceu que, pelas características menos intervencionistas de seus cuidados, o profissional não médico é o mais apropriado para o acompanhamento das gestações e partos de risco habitual, sendo capaz de reconhecer e identificar complicações (DAVIS-FLOYD, 2001; OMS, 1996).

Todavia, a assistência ao parto ainda é vista como atividade privativa do médico, em que outros profissionais, como as enfermeiras obstétricas, atuam na prática assistencial em apenas algumas regiões do país. Historicamente, as relações entre médicos e não médicos foram traçadas pela hierarquização, com a classe médica sendo superior nas questões técnicas e econômicas. Porém, a classe da enfermagem obstétrica possui autorização legal para prestar atendimento ao parto, de acordo com o decreto $\mathrm{n}^{\circ} 94.406 / 87$, que dispõe sobre o exercício profissional, em seu Art. $9^{\circ}$ (BRASIL, 1987). 
As profissionais titulares de diploma ou certificado de Obstetriz ou Enfermeira Obstétrica, além das atividades de que tratam as funções generalistas, incumbe:

I - Prestação de assistência à parturiente e ao parto normal;

II - Identificação das distócias obstétricas e tomada de providências até a chegada do médico;

III - Realização de episiotomia e episiorrafia, com aplicação de anestesia local, quando necessária.

Em todo o país, vários grupos solidários e não governamentais se organizam com o objetivo de assegurar melhores práticas obstétricas e resgatar o nascimento como evento existencial, como, por exemplo, a Rede de Humanização do Nascimento (OSAVA, 1997).

O MS (BRASIL, 2001) iniciou uma série de medidas e políticas públicas visando à redução dos índices de morbimortalidade materna e perinatal, reconhecendo a importância da enfermeira obstétrica para a melhoria dos índices e da assistência em si. Em 29 de Maio de 1998, o MS publicou a Portaria n ${ }^{\circ} .2815$ de 29 de maio de 1998, incluindo o procedimento parto normal sem distócia realizado por enfermeira obstétrica. Em 2007, no âmbito da saúde suplementar, por meio da Resolução Normativa n. 167, o MS regulamenta e fornece direito à paciente a ter seu parto assistido por enfermeira obstétrica, possibilitando o recebimento de honorários (BRASIL, 1998; 2007).

As enfermeiras obstétricas também devem atuar no atendimento ao pré-natal de baixo risco, nos programas de educação em saúde, além de serem reconhecidas como primordiais para exercer atividades relacionadas ao parto e nascimento, objetivando uma mudança cultural nas instituições, voltando o modelo de atenção à mulher à forma individualizada e sem intervenções desnecessárias, diminuindo assim a taxa de 
morbimortalidade materna e os altos índices de cesarianas praticados em nosso país (BRASIL, 2001; 2006).

Neste sentido, em 1999, o MS cria a Portaria $n^{\circ} .985$ de 05 de agosto de 1999, instituindo o Centro de Parto Normal (CPN), coordenado exclusivamente por enfermeiras obstétricas, enfatizando a necessidade de humanização na assistência. Também criado para melhorar a assistência à mulher no ciclo gravídico puerperal, o Programa de Humanização ao Pré-Natal e Nascimento foi implementado a nível estadual e municipal (BRASIL, 1999a).

Em 2011, o MS instituiu a Rede Cegonha, buscando assegurar à mulher uma atenção qualificada e humanizada ao ciclo gravídico puerperal, atuando de forma integrada com as demais iniciativas para a saúde da mulher no SUS. A Rede Cegonha surge para garantir o compromisso internacional assumido pelo Brasil no cumprimento dos Objetivos de Desenvolvimento do Milênio (ODM), especialmente a meta cinco que trata da redução da mortalidade materna em três quartos até 2015 e que não foi possível alcançar no tempo proposto. A iniciativa também prevê a qualificação dos profissionais de saúde responsáveis pelo atendimento às mulheres durante este período, criando, desta forma, Casa da Gestante, Casa dos Bebês e CPNs. Há também a necessidade de atingir metas de qualidade assistencial na assistência ao parto e nascimento e diminuir práticas desnecessárias (BRASIL, 2011a).

O Conselho Federal de Enfermagem, por meio da Resolução no 516/2016 instituiu que as enfermeiras obstétricas devem atuar de forma integrada às Redes de Atenção à Saúde, garantindo atendimento integral e de qualidade, baseado em evidências científicas e 
humanizado, às mulheres, seus recém-nascidos e familiares e/ou acompanhantes (CONSELHO FEDERAL DE ENFERMAGEM, 2016).

É possível afirmar que mesmo tendo regulamentações e portarias favoráveis, formação específica e conhecimento científico, as enfermeiras obstétricas defrontam-se com dificuldades para o exercício da profissão. Ainda há muita resistência da classe médica para a inserção desta profissional no âmbito da assistência ao parto e nascimento. O modelo ideal da assistência deve levar em conta a importância das duas categorias profissionais (MERIGHI, 2002).

As enfermeiras obstétricas encontram várias barreiras pessoais e institucionais, que muitas vezes as impedem de prestar uma atenção qualificada, logo, são necessários esforços para melhoria na formação acadêmica e na qualificação profissional, bem como a implantação de protocolos assistenciais que visem a melhoria da qualidade (NARCHI et al, 2013).

Vale ressaltar que o estudo mais atualizado, realizado no Brasil em 2014 Nascer no Brasil: Inquérito Nacional sobre Parto e Nascimento, revela que apenas $15 \%$ dos partos foram assistidos por enfermeiras obstétricas, tendo a frequência mais acentuada nas regiões mais pobres, em que há ausência do profissional médico. Esses resultados vão na contramão do que recomendam as políticas vigentes em nosso país, uma vez que deveríamos priorizar a inclusão dessas profissionais na atenção ao parto em todas as instituições que ofereçam serviços de atenção ao parto e nascimento (LEAL; GAMA, 2014).

Ainda nesta temática, a enfermagem obstétrica mostrou-se uma especialidade desprivilegiada de poder à medida que não consegue desempenhar o seu papel 
de forma efetiva nas instituições que atendem a mulher, embora, ao longo dos anos, por meio de evidências científicas, tenha se mostrado muito eficaz na redução dos índices de morbimortalidade materna e neonatal, na humanização da assistência ao parto e nascimento e na implementação de práticas não medicamentosas. Desta forma, deixa de atuar na maneira mais singular do cuidado, exercendo, muitas vezes, papéis burocráticos, longe dos ideais e do que se preconiza nas políticas públicas do nosso país.

O comportamento humano, no entanto, é influenciado diretamente pelo meio cultural, pois nos comunicamos e criamos cultura. Assim, a enfermeira obstétrica deve agir socialmente para garantir desta forma que as vivências individualizadas das mulheres sejam respeitadas nos cenários de nascimento, possibilitando momentos de tranquilidade e serenidade.

Ao exercer a prática assistencial de forma holística, a enfermeira obstétrica rompe totalmente com o modelo atual, praticando modalidades menos prejudiciais, cuidando da mulher em seu contexto, de acordo com suas necessidades e promovendo o desenvolvimento da vida de cada pessoa, respeitando suas crenças e possibilitando a dimensão espiritual do cuidado (PIMENTA, 2012). 
OBJETIVOS 


\section{OBJETIVOS}

- Compreender a vivência da enfermeira obstétrica no cenário da admissão, pré-parto, parto e pós-parto imediato;

- Interpretar os aspectos facilitadores e dificultadores de sua inserção nos serviços de atenção materna. 
PRESSUPOSTOS 


\section{PRESSUPOSTOS}

Frente ao exposto, pressupomos que a atuação da enfermeira obstétrica nos cenários de atenção à parturiente, na admissão, pré-parto, parto e pós-parto imediato possa ser dificultada devido à fragilidade de sua inserção nos serviços que atendem às mulheres e em consequência da cultura local, que figura como fator determinante nas organizações onde atuam.

As enfermeiras obstétricas desempenham papel importante para qualidade da assistência ao parto e sofrem influência de alguns fatores, como, por exemplo, a infraestrutura, que pode desempenhar um papel facilitador ou comprometedor, assim como o aprimoramento profissional, que exerce influência direta na qualidade assistencial. 
REFERENCIAL TEÓRICO:

ABORDAGEM ANTROPOLÓGICA NA ATUAÇÃO DA ENFERMEIRA OBSTÉTRICA NA ASSISTÊNCIA AO PARTO 


\section{REFERENCIAL TEÓRICO: ABORDAGEM ANTROPOLÓGICA NA ATUAÇÃO DA ENFERMEIRA OBSTÉTRICA NA ASSISTÊNCIA AO PARTO}

Nas últimas décadas, na tentativa de perceber os fatores culturais que atravessam e estão presentes no ambiente das maternidades e centros obstétricos, tem havido uma preocupação com a prática de enfermagem além da lógica biomédica. Discussões têm sido geradas sobre a influência cultural que permeia a práxis profissional, especialmente no ramo da obstetrícia. Estudos têm sido realizados em diferentes abordagens, cada qual com linhas e pensamento sobre a cultura organizacional (GEERTZ, 2001; 2006; 2014).

Sendo o cenário do nascimento um espaço de encontros de subjetividades, constituindo num ambiente de colisões de egos, de vaidades, regulados por histórias de vida dos atores envolvidos, é comum que, neste ambiente, ocorram incidências determinadas por dimensões culturais. As relações das enfermeiras obstétricas com o usuário do serviço, com seus pares, com os médicos, com os familiares dos pacientes e com a equipe administrativa do hospital se caracterizam pelo envolvimento de relações interpessoais que convergem para encontros de cultura, sendo esta nada mais do que um conjunto de ideias que determinam um grupo (GEERTZ, 2001; 2006; 2014).

Em conformidade com estudos de Laplantine (2000), a antropologia se ocupa em estudar todas as sociedades humanas (a nossa inclusive), ou seja, das culturas da humanidade como um todo, em suas diversidades históricas e geográficas.

Estudo realizado por Souza et al. (2010) concluiu que a antropologia deixa bem claro que os homens que atuam nas dimensões biopsicossocial e econômico-política do processo saúde/doença o fazem por meio de processos ideológicos baseados na experiência pessoal e grupal, em crenças, percepções, atitudes e práticas, realizando desta forma a 
aproximação entre as concepções biomédica e cultural. A abordagem da antropologia interpretativa amplia o olhar, permitindo mudanças na relação profissional/usuário/cliente, e esse olhar pode resultar em cuidados e práticas como uma escuta atenta, com interesse pelo outro (usuário) e disponibilidade para juntos buscarem formas singulares para enfrentar as situações vivenciadas. Assim, as enfermeiras obstétricas podem buscar, no cuidado individualizado, a melhor forma de atuar, entregando para a parturiente e sua família a assistência de enfermagem mais completa e próxima das necessidades da cliente.

Desta forma, a prática da enfermagem obstétrica é atravessada transversalmente pela cultura que cada profissional conduz para o seu ambiente de trabalho, interferindo em todas as relações estabelecidas por este profissional, permitindo assim uma assistência prestada mais uniforme entre os atores envolvidos no processo de promoção de saúde, de forma a traduzir um novo olhar sobre a influência da cultura nas interpretações.

Assim, com a finalidade de atender aos objetivos deste estudo e fornecer a sustentação teórica, optou-se pelo suporte conceitual da antropologia, tomando o pensamento do antropólogo Clifford Geertz, considerado um dos principais representantes da Antropologia Interpretativa, com seus pensamentos transmitidos por meio de seus estudos sobre a interpretação da cultura (GEERTZ, 2001; 2006; 2014).

Para Geertz (2014), o pensamento humano é completamente social na sua origem, em suas funções, em suas formas e em suas aplicações. De forma elementar, é uma atividade pública, seu habitat natural é o pátio da casa, o local do mercado, a praça da cidade. O pátio da casa a que se refere o autor entende-se em nosso estudo como o cenário do nascimento, nas maternidades e centros obstétricos, contexto onde os profissionais da enfermagem obstétrica exercem a sua práxis. 
Para desvelar o complexo mundo da experiência, o pensamento da antropologia interpretativa busca compreender o mundo da experiência do ponto de vista daqueles que a vivem. Desta forma, faz-se necessário interpretar o mundo do sujeito, ilustrando o processo de construção de significados e desvelando como estão incorporados na linguagem e nas ações dos sujeitos e, desta forma, explicar as inúmeras funções humanas e suas inter-relações (SILVA et al., 2000).

A experiência pode ser a de todos os sujeitos, mas cada uma desenvolve um conhecimento através de uma elaboração interior, de forma subjetiva e intersubjetiva, interposta pelo senso comum, pelas experiências vividas, servindo como referência para cada indivíduo (MINAYO, 2006).

Em vista disso, segundo Geertz (2014), ao compreendermos entendimentos diferentes do nosso, podemos interpretar e respeitar os significados dados pelos diferentes sujeitos ao mesmo conteúdo e conciliados com a cultura dos indivíduos. Assim, há uma contribuição de cada indivíduo para a formação da assistência ideal.

A experiência vivida por uma pessoa é única e não pode ser transferida para outra em sua totalidade. É possível manter as experiências de forma privada, tornando-as públicas com o seu discurso e a sua linguagem intencional (SILVA et al., 2000).

Em conformidade com a antropologia interpretativa, precisamos procurar relações sistemáticas entre os fenômenos diversos, não identidades substantivas entre os fenômenos similares, e em conseguinte precisamos substituir a concepção das relações entre os vários aspectos da existência humana por fatores biológicos, psicológicos, sociológicos e culturais e, desta forma, trata-los como variáveis dentro dos sistemas unitários de análise. É uma questão de integrar diferentes tipos de teorias e conceitos de tal forma que se possa 
formular proposições significativas incorporando descobertas que hoje estão separadas em áreas estanques de estudo (GEERTZ, 2014).

Corroborando este pensamento, é possível compreender as práticas culturais inseridas em contexto cultural mais amplo, nos ambientes hospitalares, articulando as relações entre os fenômenos específicos e uma determinada visão do mundo.

Outrossim, a cultura pode ser considerada como um conjunto de princípios, implícitos ou explícitos, que são obtidos pelos membros da sociedade e que traduzem a maneira de vida de uma comunidade, o seu modo de enxergar o mundo, de vivenciá-lo emocionalmente, de comportar-se dentro dele em relação aos outros (LEMOS; ROSSI, 2002).

Assim, a organização da vida social acontece por meio de símbolos, imagens, como sinais, costumes, representações, que devemos captar para entender o significado. Desta forma, a cultura é a maneira de controle, pois os significados dados a eventos, falas, atos, são influenciados pela cultura vivenciada pelo homem durante a sua vida. A cultura produz a subjetividade de cada ser, o que o torna um ser inacabado e dependente da cultura, ou seja, um ser que é produzido pela cultura mas que, ao mesmo tempo, também a produz. Logo, sem os homens certamente não haveria cultura, mas, de forma semelhante e muito significativamente, sem cultura não haveria homens, relação traduzida pela expressão “teias de significados".

Estudando a cultura das organizações, especialmente das maternidades, e como se organizam as relações, pode-se suscitar o favorecimento de questões referentes aos trabalhadores e à gestão, podendo emergir a forma com que esses sujeitos entendem suas experiências e como essas experiências se relacionam com a prática que é efetivamente 
operacionalizada por eles. O resultado da discussão dos sujeitos a respeito do seu mundo e do seu trabalho e vice-versa.

A cultura nestes ambientes é composta de diferentes sujeitos, sendo assim interpretada de distintas maneiras, pois as pessoas possuem atribuições diferentes na sociedade e mesmo no próprio ambiente de trabalho, repercutindo assim na sua versão e visão acerca da cultura.

Desta forma, a abordagem antropológica da cultura tem como objetivo compreender e interpretar o significado das ações dos sujeitos de uma sociedade, em um determinado espaço e tempo, de modo a interligá-lo, convertendo-as em conceitos científicos.

Por esta razão, as experiências vivenciadas pelas enfermeiras obstétricas, a valorização das formas de agir e pensar, as facilidades e dificuldades encontradas no exercício de sua profissão, no reconhecimento de seu grupo social, ou seja, sua cultura, são fatores que poderão servir de base para ações comunitárias e sociais no intuito de trocar experiências, encorajar grupos e melhorar a assistência prestada. 
PERCURSO METODOLÓGICO 


\section{PERCURSO METOdOLÓGICO}

\subsection{Desenho do estudo}

Tendo como objetivo compreender a vivência da enfermeira obstétrica no cenário da atenção ao parto e interpretar os aspectos facilitadores e dificultadores de sua inserção nos serviços de atenção materna, a escolha pela abordagem metodológica qualitativa mostrou ser a mais adequada. Essa metodologia traz como concepção a compreensão do universo dos significados culturais e a perspectiva de mundo que permeia a experiência dessas enfermeiras.

A pesquisa qualitativa é relevante no estudo das relações sociais devido à pluralização das esferas da vida. A metodologia qualitativa explora a experiência vivenciada pelas pessoas no dia a dia, pois tem como premissa compreender questões da realidade que não se podem quantificar, para entender, conhecer, interpretar um fenômeno, situações e eventos, atuais ou passados (FLICK, 2009; HAGUETTE, 2001; MINAYO, 2006).

Logo, a pesquisa qualitativa permite a visão de dentro do grupo analisado, ou seja, o conhecimento próprio do indivíduo pertencente a uma cultura determinada, expresso na lógica interna do seu sistema de conhecimento (VICTORIA et al., 2000).

A escolha pela abordagem qualitativa é justificada visto que permite levar à descoberta do significado deste foco de pesquisa, já que utiliza estratégias como observação, documentação, entrevistas e fotografias, e explora a experiência das pessoas procurando saber como veem e como se sentem quando confrontadas com as situações estudadas (LÜDKE; ANDRÉ, 1986). 


\subsection{Campo de estudo}

O estudo foi realizado no município de Londrina, localizada no norte do estado do Paraná, a $369 \mathrm{~km}$ de Curitiba, capital paranaense. O nome da cidade foi uma homenagem prestada a Londres - "pequena Londres", pelo Dr. João Domingues Sampaio, um dos primeiros diretores da Companhia de Terras Norte do Paraná (LONDRINA, 2008).

Londrina apresentou um crescimento acelerado e contínuo nos últimos anos, tornando-se não só polo regional, como a quarta maior cidade do Sul do País, logo na sequência de Curitiba, Porto Alegre e Joinville.

A população de Londrina, de acordo com o censo de 2010 do Instituto Brasileiro de Geografia e Estatística (IBGE), é de 511.278 habitantes, tendo aproximadamente 170 mil mulheres em idade fértil (IBGE, 2010).

É a primeira cidade do Brasil a contar com uma Secretaria Especial da Mulher, que oferece atendimento social, jurídico e psicológico à mulher vítima de preconceito, violência e discriminação (LONDRINA, 2008).

Em se tratando da organização dos serviços de saúde, a cidade conta com a Atenção Básica desenvolvida pela Autarquia Municipal de Saúde, caracterizada como porta de entrada do SUS, em 52 unidades básicas de saúde, sendo 13 na área rural e as demais na área urbana (LONDRINA, 2010).

A cidade conta com 23 unidades hospitalares nas diversas áreas de atendimento, das quais cinco prestam atendimento à saúde da mulher. Ao todo são realizados em torno de 7000 partos por ano, com uma média mensal de 580 nascimentos. A taxa de cesarianas no ano de 2010 foi de $58 \%$ e a de parto normal $42 \%$, muito aquém do preconizado pelo MS e pelas organizações mundiais. Vale ressaltar que a enfermeira obstétrica é presente 
em todos as unidades hospitalares que prestam atendimento às mulheres na cidade de Londrina (LONDRINA, 2010).

O campo de estudo foi constituído por três hospitais do município de Londrina que possuem atendimento à mulher no processo de parto e nascimento e uma empresa que presta serviços de enfermagem obstétrica nestas instituições. Tivemos dois pedidos negados, devido a essas instituições não permitirem a manipulação de câmeras fotográficas no ambiente do trabalho.

Das instituições participantes, duas instituições prestam atendimento estritamente privado, uma instituição atende estritamente pelo Sistema Único de Saúde (SUS) e uma instituição presta atendimento filantrópico, versando entre os sistemas público e privado. Para garantia do sigilo com relação à identidade das instituições participantes, foram atribuídos nomes fictícios.

\subsubsection{Instituição Lua}

Esta instituição atende exclusivamente pacientes particulares e presta serviços de acompanhamento de pré-natal, parto e puerpério no domicílio e em instituições hospitalares na cidade de Londrina e Cambé, no estado do Paraná. Iniciou suas atividades em 2015.

A equipe é formada por dois médicos obstetras e três enfermeiras obstétricas. Durante o pré-natal, a gestante conhece toda a equipe e, desta forma, fica ciente que qualquer membro da equipe poderá atendê-la sempre que precisar. A equipe permanece à disposição da família para esclarecimento de dúvidas e atendimentos que se fizerem necessários. 
Nos primeiros sinais de trabalho de parto, a gestante entrará em contato com o médico, que tomará a conduta e fará as orientações necessárias, avisando assim a enfermeira obstétrica que está de plantão. A paciente poderá ser atendida em consultório ou no domicílio, e após avaliação, a equipe médica e as enfermeiras obstétricas discutem o caso e definem a conduta (internação ou aguardar evolução em casa) em parceria com a família.

A enfermeira obstétrica da instituição Lua atende exclusivamente procedimentos e acompanhamento obstétricos (verificação de dinâmica uterina, ausculta de batimentos cardiofetais, toques vaginais e demais procedimentos obstétricos), ficando a cargo da equipe de enfermagem os demais procedimentos, tais como: punção venosa, sondagem vesical, verificação dos sinais vitais etc.

A enfermeira obstétrica oferece assistência durante o trabalho de parto e parto, bem como ajuda a mulher a lidar com a dor do trabalho de parto, fornecendo métodos não farmacológicos para o relaxamento e alívio. Os casais atendidos elaboram um plano de parto, e a equipe que estiver atendendo se compromete a seguir integralmente, salvo no caso de complicações maternas ou fetais.

O binômio (mãe e bebê) é acompanhado pela equipe de enfermeiras obstétricas em torno de duas horas após o parto, e, se dentro da normalidade, são realizados os cuidados iniciais com o recém-nascido. Uma semana após o parto, a família receberá uma visita para avaliação.

A equipe também oferece serviços de cuidados à amamentação, técnica shantala, banho no balde para o recém-nascido e colocação do primeiro brinco.

Apesar de ser um serviço estritamente privado, a atuação tem ganhado espaço e já realizou o atendimento a cinco famílias, tendo mais três agendadas para este ano. 


\subsubsection{Instituição Sol}

Trata-se de um hospital filantrópico, com ênfase no atendimento a gestantes de alto risco. Possui atualmente 350 leitos, dos quais 46 são destinados ao atendimento na ala de Maternidade, com 9 deles reservados ao atendimento ao SUS.

Passou por uma ampla reforma em sua estrutura de maternidade e hoje atende com dois postos para assistência de enfermagem, uma sala de avaliação e admissão equipadas com dois aparelhos de CTG (Cardiotocografia), sonar, carrinho de emergência, além de sala de apoio ao recém-nascido e duas salas de parto, uma localizada no centro obstétrico equipada com cama PPP (Pré-Parto - Parto - Puerpério) e outra localizada na ala de internação equipada com banheira de hidromassagem; ambas possuem acesso restrito a pessoas previamente autorizadas.

Em seu quadro funcional apresenta enfermeiras obstétricas em todos os horários, médicos obstetras e pediatras, além de uma equipe multidisciplinar que dá suporte, com psicólogo, nutricionista e fonoaudióloga.

A gestante conveniada pelo SUS somente recebe atendimento se encaminhada por um serviço de apoio, SAMU (Serviço de Atendimento Móvel de Urgência), SIATE (Sistema Integrado de Atendimento ao Trauma em Emergência), ou em caso de transferência de outra instituição. Os atendimentos de procura direta são realizados para gestantes com convênio ou para atendimento particular.

A enfermeira é o profissional que presta o primeiro atendimento à gestante na ala da maternidade. Algumas vezes o médico encaminha uma solicitação de internação direta, pulando o atendimento da sala de admissão e indo diretamente para o quarto. A 
enfermeira realiza o exame físico geral e obstétrico, a CTG, faz exame de toque vaginal e passa toda sua avaliação para o médico. O médico plantonista fica à distância na maioria das vezes e comparece na instituição para a tomada de decisão sobre o destino da gestação, internação ou alta. A autorização para internação é determinada pelo médico, assim há a solicitação da AIH (Autorização para Internação Hospitalar).

Após o nascimento o recém-nascido fica com a mãe e, somente quando solicitado pela família, ele é levado para uma sala de apoio para o atendimento inicial, onde recebe vitamina $\mathrm{K}$ e vacina de Hepatite $\mathrm{B}$, é vestido e encaminhado para ficar com sua mãe, sendo o banho realizado pela mãe assim que possível.

A equipe do hospital ministra um curso de gestantes com periodicidade bimestral, com palestras sobre diversos temas para os casais. O curso conta com sete encontros com uma equipe multidisciplinar.

Há investimento em cursos de aprimoramento nas seguintes áreas: manejo do aleitamento materno, humanização e parto adequado, manejo do trabalho de parto, teste do pezinho e do coraçãozinho e recepção do recém-nascido na sala de parto, além dos tradicionais de enfermagem, como anotação, isolamento e cuidados com medicações.

O hospital participa do Projeto Parto Adequado, uma iniciativa em parceria com o Hospital Israelita Albert Einstein e Institute for Healthcare Improvement, com apoio do MS, visando assim identificar modelos inovadores e viáveis de atenção ao parto e nascimento, orientando a adoção de boas práticas, como a valorização do parto normal e redução do percentual de cesarianas desnecessárias na saúde suplementar. 


\subsubsection{Instituição Estrela}

Esta instituição é mantida pela Autarquia do Serviço Municipal de Saúde (ASMS) e presta serviços exclusivamente pelo SUS.

Foi inaugurada em 1992 e atende cerca de 75\% dos partos do SUS realizados no município, sendo referência à gestante de baixo e médio risco que fazem ou não pré-natal na rede básica de saúde.

Nela trabalham 26 médicos, dos quais dez obstetras, oito anestesistas e oito pediatras, 16 enfermeiras e 68 técnicos de enfermagem. A equipe de enfermagem assume jornada de trabalho de 30 horas semanais. Alguns profissionais trabalham em plantões extras para cobrir folgas, sendo estas variáveis a cada mês.

Conta com uma equipe multidisciplinar constituída por enfermeiras, enfermeiras obstétricas, técnicos e auxiliares de enfermagem, médicos obstetras, pediatras, anestesiologistas, nutricionistas e profissionais de apoio.

Adepta ao sistema de Alojamento Conjunto e a não utilização de bicos artificiais desde a sua implantação, a instituição Estrela usa a promoção, proteção e manutenção do aleitamento materno, tendo conquistado o título de "Iniciativa do Hospital Amigo da Criança", preconizado pela UNICEF/OMS, em 04 de julho de 2000.

Já em 2006, a Estrela recebeu o prêmio Galba de Araújo, oferecido pelo MS para destacar hospitais que mais investem no parto normal e atendimento humanizado a gestantes e bebês.

Em 2015 foram realizados 3182 partos, dos quais 2129 foram partos normais e 1053 partos cesáreas, evidenciando a taxa média de 33\% de partos cesáreas. 
Em sua estrutura física, apresenta a recepção, unidade de pré-parto e parto, centro obstétrico, centro de material, unidade de recém-nascido, unidade de alojamento conjunto e área administrativa.

A unidade de pré-parto e parto é constituída por duas salas para consultas de admissão, onde o médico ou estudante de medicina realizam o atendimento. Neste momento é permitida a presença de acompanhante. A equipe de enfermagem participa realizando a abordagem inicial, verificando SSVV (Sinais Vitais) e coletando exames quando necessário. Esta ala é dividida por uma porta e no ambiente seguinte situam-se o pré-parto e as salas de parto. Em todos os atendimentos é realizada a CTG; há dois lugares específicos equipados com poltronas confortáveis. O profissional de enfermagem instala o equipamento e retira após o tempo determinado. Não é permitida a presença de acompanhantes durante o exame. Após a realização do exame, a gestante volta para a admissão e aguarda o final do atendimento pelo médico.

Após a avaliação, quando detectada a necessidade de internação, a gestante é encaminhada ao pré-parto pela auxiliar ou técnica de enfermagem. A Autorização de Internação Hospitalar (AIH) é gerada em nome do médico plantonista.

Há 8 leitos no setor de pré-parto, divididos em três quartos. O primeiro quarto comporta quatro pacientes; é equipado com um banheiro para uso exclusivo das gestantes internadas (vaso sanitário, pia e chuveiro). Os leitos são separados por biombos fixos e há um biombo móvel, todo ilustrado com informações sobre práticas de humanização e desenvolvimento do parto. Nesse quarto também há um banquinho em forma de U, um cavalinho e duas bolas para realização de exercícios e auxiliar no momento do parto. Os segundo e terceiro quartos são semelhantes, mudando apenas para dois leitos a capacidade em cada um. 
A analgesia para parto normal não é realizada com frequência, pois há apenas um anestesiologista de plantão.

No mesmo ambiente, há três salas de parto, sendo que uma dessas está equipada com mesa diferenciada, a PPP, que permite maior liberdade para a parturiente e mudança de posição. Essa sala é utilizada na maioria das vezes por partos assistidos pelas enfermeiras obstétricas. A composição das salas é praticamente a mesma: mesa ginecológica, berço aquecido, material de reanimação neonatal, estetoscópio e esfignomanômetro adulto, medicamentos e materiais cirúrgicos, rede de oxigênio, aspiração e ar comprimido canalizados.

Após o parto, o recém-nascido fica em contato com a mãe por uma hora, e depois é encaminhado para a sala de higienização, onde recebe os cuidados iniciais e o primeiro banho. A puérpera aguarda o final do parto na sala de parto e, após a liberação da equipe que a assistiu, fica em uma maca, no corredor, assistindo aos procedimentos realizados em seu filho. Após o término dos cuidados com o recém-nascido, o binômio aguarda liberação da enfermeira do pré-parto; é então solicitada uma vaga no alojamento conjunto. A enfermeira do alojamento conjunto libera uma equipe de funcionários que busca e aloja o binômio.

O acompanhante permanece com a paciente durante todo período de internação no pré-parto e parto, independente da via de parto, e é permitido acompanhar o puerpério por mais $24 \mathrm{~h}$.

Em caso de necessidade de observação do recém-nascido, há uma unidade de internação, composta de cinco leitos e equipada com respirador infantil, incubadoras e berço aquecido. Quando há maior gravidade no estado geral do recém-nascido, há transferência dele para uma Unidade de Terapia Intensiva em outro hospital de maior porte. 
O alojamento conjunto é formado por 36 leitos organizados da seguinte forma: em dois quartos há capacidade para três binômios, nos outros a capacidade é para dois. Os quartos são equipados com poltronas e banheiro.

Os recém-nascidos são vacinados contra hepatite B e BCG. Fazem o teste do pezinho, da orelhinha e do coraçãozinho, e antes de receberem alta já é feita a certidão de nascimento, pois há um convênio com os cartórios da cidade para essa realização.

A instituição investe em cursos de aperfeiçoamento nas seguintes áreas: Prevenção e controle de infecções, aleitamento materno e instrumentação cirúrgica.

Há ainda o programa Rosa Viva, que atende mulheres vítimas de violência sexual a partir de 12 anos de idade. A enfermeira e o médico de plantão prestam atendimento emergencial nas primeiras 72 horas, coletam secreções e exames e fazem os devidos encaminhamentos para delegacia, atendimento psicológico e instituto médico legal, caso se fizer necessário.

Neste ano a instituição passou pelo primeiro monitoramento para implantação da Rede Cegonha, cumprindo com todos os critérios estabelecidos pelo programa.

\subsubsection{Instituição Água}

Esta instituição foi inaugurada em 2008, prestando serviços hospitalares a clientes exclusivamente privados e conveniados da saúde suplementar. Possui 41 leitos divididos em duas unidades e oito leitos de UTI (Unidade de Terapia Intensiva).

Apresenta em sua estrutura 6 salas cirúrgicas, uma sala de avaliação para admissão de gestantes, um aparelho de CTG, um berçário com capacidade para atendimento e 
observação de quatro recém-nascidos. Possui aparelho de USG (Ultrassonografia) e demais serviços terceirizados. Funciona com alojamento conjunto e capacidade para internação de 15 binômios.

As avaliações de admissão são realizadas por enfermeiras obstétricas, que fazem o atendimento inicial e passam o exame realizado para os médicos obstetras. Não possui sala exclusiva para pré-parto ou centro obstétrico, o nascimento acontece no centro cirúrgico. Após o nascimento o recém-nascido é apresentado a mãe e encaminhado ao berçário, onde recebe os cuidados iniciais. É estimulado o aleitamento materno na primeira hora de vida, salvo em casos onde há intercorrências com a mãe ou com o recém-nascido.

$\mathrm{O}$ atendimento primordial do hospital é para cirurgias eletivas, apresenta a realização de 650 cirurgias/mês em média, o que representa uma média anual de 7800 procedimentos cirúrgicos realizados por ano. Em 2015 foram assistidos 554 partos, dos quais 526 cesarianas e 28 partos normais. $\mathrm{O}$ atendimento é exclusivo para gestantes de baixo risco.

O hospital investe em treinamentos para os funcionários da enfermagem nas seguintes áreas: atendimento ao recém-nascido, cuidados com incubadora, fototerapia, aleitamento materno e cuidados com o puerpério.

\subsection{Participantes do estudo}

Por se tratar de estudo de natureza qualitativa, o número de enfermeiras obstétricas participantes não foi predeterminado, definindo-se ao longo da coleta de dados, ou seja, à medida que ocorria repetição de conteúdos completou-se a coleta. Para essa abordagem, de processo de amostragem por saturação teórica, o critério fundamental não foi o quantitativo mas sua possibilidade de incursão, ou seja, quando os dados começam a repetir, 
não sendo necessária a continuidade da coleta de dados, estabelecendo assim o tamanho amostral na pesquisa qualitativa (DENZIN; LINCONL, 1994).

Seguindo por este princípio, Fontanella et al. (2008) estabelecem que sejam consideradas para a análise de saturação amostral os objetivos da pesquisa, o referencial teórico, o grau de profundidade das entrevistas, de forma a garantir que a população estudada estivesse contemplada de forma homogênea e heterogênea. Neste sentido, no instante em que as particularidades da atuação das enfermeiras obstétricas foram desveladas e as facilidades e dificuldades no exercício de suas atividades laborais encontradas, transmitindo assim o universo de sua atuação, foram tornando-se repetidas e equivalentes e a busca por mais sujeitos foi encerrada.

Esta pesquisa foi composta por enfermeiras obstétricas com pelo menos um ano de experiência, que atuam/atuaram nos serviços de cuidados à Saúde da Mulher durante o trabalho de parto, parto e pós-parto imediato nas maternidades e hospitais da cidade de Londrina.

A primeira etapa da pesquisa foi composta por uma entrevista individual, cujas questões fazem parte do roteiro de entrevista semiestruturada individual (Apêndice A). Nesta etapa foram realizadas 20 entrevistas com profissionais do sexo feminino.

\subsection{Procedimento de coleta de dados}

Para a realização deste estudo, foram desenvolvidas duas etapas. A primeira etapa foi composta por uma entrevista individual semiestruturada e na segunda etapa foi utilizada a metodologia Photovoice, definido como a criação de imagens e fotografias 
produzidas pelas próprias enfermeiras obstétricas, acompanhada de uma reflexão coletiva sobre as imagens produzidas, com a realização de um grupo focal.

\subsubsection{Entrevistas Individuais}

Inicialmente, foi consultado nas instituições participantes o número de enfermeiras obstétricas que atuavam na assistência às mulheres durante o trabalho de parto e parto e aquelas que contemplavam os critérios de inclusão. Concluída esta consulta, o convite para participar da pesquisa foi realizado durante os dias de trabalho na instituição. As entrevistas individuais aconteceram no ambiente de trabalho das profissionais, em um espaço que proporcionou privacidade e respeito aos preceitos éticos, aos profissionais e à pesquisadora. Desta forma, evitou-se interrupções, distorções nos diálogos e desconfortos para o entrevistador e para os sujeitos da pesquisa.

Realizaram-se 20 entrevistas semiestruturadas, gravadas e transcritas na íntegra. As entrevistas semiestruturadas são geralmente utilizadas quando os pesquisadores possuem tópicos amplos a serem abordados, de forma a utilizar uma estrutura flexível, com questões e/ou tópicos abertos, para inicialmente ser explorada de forma mais superficial e posteriormente ser abordada de forma aprofundada. Neste formato, é possível o aparecimento de outras questões não listadas no roteiro (POPE; MAYS, 2008; POLIT; BECK, 2011).

O roteiro utilizado para entrevista foi produzido no sentido de contemplar os objetivos propostos por esta pesquisa (Apêndice A). Após a entrevista, as enfermeiras obstétricas foram convidadas a participar da etapa Photovoice. Nesta etapa todas as enfermeiras obstétricas aceitaram participar da coleta de fotografias, porém dez enfermeiras obstétricas compareceram à reunião de grupo. 


\subsubsection{Photovoice}

Para a segunda etapa deste estudo, adotou-se a metodologia Photovoice, pois segundo Palibroda et al. (2009), uma metodologia inovadora para pesquisas participativas, cuja essência é a mistura de imagens e palavras. Esta mistura de palavras e imagens não é uma ideia nova, na verdade, nós humanos utilizamos diferentes tipos de imagens e palavras para expressar o que precisamos, o que tememos, nossos sonhos e todos os tipos de ideias que possamos ter. Portanto esta mistura de imagens e palavras fortalece as pessoas, pois compartilham ideias e preocupações sobre suas experiencias e sua comunidade. Acreditamos que por atuarem de forma marginalizada, ao utilizar as fotografias, as enfermeiras obstétricas poderão identificar as lacunas na atuação e os fatores facilitadores e dificultadores de sua assistência e existência profissional.

Este método foi desenvolvido por Carolina Wang e Mary Ann Burris, professora e pesquisadora da Universidade de Michigan e investigadora da Escola de Estudos Orientais e Africanas da Universidade de Londres, respectivamente, no início da década de 90 (WANG; BURRIS, 1997; WANG, et. al., 1998; WANG, 2003; CATALANI; MINKLER, 2009; SOUZA, 2013). O método foi utilizado pela primeira vez por um grupo de mulheres na China rural para o levantamento de saúde das mulheres que viviam naquela comunidade, no qual subsidiou a elaboração de ações do governo e favoreceu a avaliação destas políticas.

O Photovoice foi desenvolvido como uma abordagem criativa na forma de pesquisa-ação participativa, com o propósito de capacitar os grupos marginalizados através do uso de fotografias e encontros grupais e assim, identificar, representar e melhorar a comunidade, uma vez que gera oportunidades para indivíduos marginalizados tirarem fotografias e contarem suas histórias e desta forma, mostrarem o mundo através de seus olhos (SOUZA, 2013; PALIBRODA, et al., 2009; WANG; BURRIS, 1997). 
Segundo suas criadoras, os três principais objetivos deste método são: 1) Permitir que as pessoas fotografem e reflitam os pontos fortes e os problemas de sua comunidade; 2) Promover o diálogo crítico e o conhecimento sobre as questões importantes através de discussões em grande e pequeno grupo e 3) Alcançar os formuladores de políticas (WANG; BURRIS, 1997).

A câmera fotográfica é uma das ferramentas mais populares e mágicas utilizadas para apresentarem ao mundo as experiências vivenciadas durante toda a vida coletiva e individual, contam histórias e mostram o que é relevante na vida das pessoas (PALIBRODA et al., 2009).

A criação deste método foi fundamentada teoricamente a partir de três ideias fundamentais: Educação para consciência crítica; Teoria feminista e Fotografia documental (SOUZA, 2013; PALIBRODA, et al., 2009; WANG; BURRIS, 1997).

A primeira ideia, educação para consciência crítica, está fundamentada na abordagem da "educação crítica" de Paulo Freire, no qual defende que a educação de problematização começa com questões em que as pessoas vêem como fundamentais para suas vidas e, em seguida, lhes permite identificar temas comuns através do diálogo. Ou seja, uma vez que grupos oprimidos, isto é, grupos marginalizados, começam a refletir individualmente ou coletivamente sobre a sua situação social, há possibilidade de quebrarem a cultura do silêncio através da articulação, do descontentamento e da ação (SINGHAL et al, 2007).

Freire observou que um dos meios de permitir que as pessoas pensem criticamente sobre sua comunidade e começar a discutir as forças sociais e políticas cotidianas que influenciam suas vidas, poderia ser com o uso de desenhos, fotografias ou imagens, e foi com este entendimento, do uso das imagens conceito, que a proposta do Photovoice avançou 
ao trabalhar com fotos produzidas pelas próprias pessoas (PALIBRODA, et al., 2009; WANG; BURRIS, 1997).

O segundo conceito teórico que fundamentou a criação do método Photovoice foi a teoria e a prática feminista, no qual denunciou o viés masculino presente nas pesquisas participativas, tornando as mulheres muitas vezes invisíveis. A teoria feminista sugere a compreensão da natureza das desigualdades, examinando o papel social, as experiências, os interesses, as tarefas e as políticas de cada grupo em uma variedade de campos, tais como antropologia e sociologia, comunicação, educação e saúde, representando o conceito do método Photovoice (PALIBRODA, et al., 2009; WANG; BURRIS, 1997).

A terceira ideia apontada como fundamentação teórica refere-se à fotografia documental por ter sido utilizada para descrever uma imensa variedade de estilos visuais, de gêneros e compromisso. A possibilidade de acesso da fotografia à uma comunidade, foi descrita por Jô Spence, fotografo e educador inglês, como um instrumento que pode ser utilizado como ferramenta para a mudança social, e acrescentou que a fotografia tem a vantagem de ser de simples manuseio e acesso (PALIBRODA, et al., 2009; WANG; BURRIS, 1997).

Como uma estratégia participativa, Wang e Burris consideram, ainda, que o método possibilita aos profissionais de saúde uma visão do mundo a partir da perspectiva da população-alvo, podendo ser uma ferramenta para alcançar, informar e organizar membros da comunidade, permitindo priorizar suas preocupações e discutir problemas reais. Para elas, o Photovoice vai além do papel convencional da avaliação de necessidades, convidando as pessoas a se tornarem defensoras dos seus próprios problemas e do bem-estar de sua comunidade (PALIBRODA, et al., 2009; WANG; BURRIS, 1997). 
Dentro desta perspectiva, as enfermeiras obstétricas poderão trocar experiências entre si, discutindo assuntos dificultadores e facilitadores de sua atuação e com a interação em grupo, podem melhorar a assistência prestada e renovar suas práticas assistenciais.

Desta forma, para contemplar os objetivos deste estudo, optou-se por realizar as nove etapas sugeridas por Palibroda et al. (2009) para a execução do Photovoice, a saber:

\subsubsection{Conectando e consultando a comunidade}

Para a realização de uma pesquisa participativa há necessidade de uma conexão entre os membros da comunidade e os pesquisadores, pois é importante construir uma relação respeitosa entre os envolvidos, para que se consiga obter os dados e uma base sólida para desenvolver um projeto que realmente contemple a população estudada. Quando o pesquisador desenvolve relacionamentos com a comunidade, estará apto a compartilhar suas ideias, oferecer feedback e responder perguntas (PALIBRODA et al., 2009).

A confiança é um ponto forte para a interação entre indivíduos e classes marginalizadas, sendo essencial que o pesquisador ganhe a confiabilidade da comunidade e também confie nos membros da comunidade. As pessoas se sentirão mais confiantes se houver uma relação mútua entre o pesquisador e a comunidade estudada, gerando uma participação mais significativa, pois se sentirão como parte do processo (PALIBRODA et al, 2009).

A utilização do Photovoice cria uma oportunidade para os membros da comunidade expressarem suas preocupações, compartilharem suas ideias e identificarem os pontos frágeis e fortes. 
Para as criadoras do método Photovoice, os membros da comunidade são as pessoas que possuem as melhores condições para fornecerem questões que reflitam o que realmente incomoda na comunidade, diferente da visão de qualquer pesquisador externo buscando as mesmas questões (PALIBRODA et al., 2009; WANG; BURRIS, 1997).

Portanto, para esta pesquisa, houve o encontro da pesquisadora com as enfermeiras obstétricas e seus gerentes, e desta forma, gerou uma aproximação e os laços ficaram mais estreitos, iniciando aqui a abordagem metodológica.

\subsubsection{Planejando o Photovoice}

O pesquisador assumirá a liderança no planejamento das atividades necessárias, tais como: desenvolver o cronograma das atividades, arrumar o local para as reuniões do grupo, organizar equipamentos, planejar e prever possíveis problemas e o seu orçamento financeiro. Os encontros grupais são ponto central do Photovoice. Todos os detalhes relacionadas as reuniões devem ser bem planejadas desde o início (PALIBRODA et al., 2009).

Nesta etapa, a pesquisadora planejou o encontro com os participantes, escolheu o local da reunião, providenciou o projetor e os gravadores, pesquisou sobre as cameras fotográficas, planejou o treinamento das participantes quanto o uso das máquinas fotográficas e desta forma, minimizou possíveis problemas na operacionalização da pesquisa.

\subsubsection{Recrutando os participantes e público-alvo}

A fase de recrutamento é marcada pela prática de atrair pessoas da comunidade estudada, convidando-as para participarem do Photovoice. Os participantes devem ser informados sobre a potencialidade da metodologia e sobre a responsabilidade de 
criar fotografias que serão utilizadas para educar pessoas de acordo com a questão social escolhida na pesquisa (PALIBRODA et al., 2009).

O primeiro encontro com as enfermeiras foi iniciado com a explicação da metodologia Photovoice, suas interfaces e propósitos. Para um melhor entendimento sobre fotografias, foi oferecido um curso básico para as enfermeiras obstétricas participantes do estudo, de forma gratuita e não obrigatória, com objetivo de ensinar o manuseio das câmeras digitais e os princípios básicos da fotografia. Não houve interesse pelo curso, pois as enfermeiras demonstraram domínio no manejo da câmera fotográfica.

\subsubsection{Iniciando o Photovoice}

Este momento do método Photovoice é marcado pela implementação do projeto, destacando duas atividades importantes: o estabelecimento do cronograma das reuniões e o encontro dos potenciais participantes. Os participantes devem se unir para o estabelecimento do grupo, quando haverá oportunidade para explicar a metodologia Photovoice e seus benefícios (PALIBRODA et al., 2009).

Os sujeitos desta pesquisa foram orientados a respeitarem os princípios éticos no momento de tirar as fotografias, não infringindo a privacidade individual, pois tirariam fotografias que representassem fielmente os problemas, o que pode gerar fotografias de pessoas e deveriam manter a privacidade e a dignidade pessoal, todas as fotografias que retratassem pessoas de forma negativa deveriam ser manuseadas de forma ética. $\mathrm{O}$ consentimento informado foi solicitado por escrito, com a apresentação do termo de consentimento livre e esclarecido (Apêndice B). Para a realização de fotos que envolviam pessoas foi solicitada autorização para sua realização por meio do "Termo de Autorização de Uso de Imagem" (Apêndice C). 
Nesta fase, os participantes pensaram nas questões norteadoras e assim determinaram o que queriam fotografar. Nesta etapa os sujeitos são orientados sobre o foco da pesquisa, são explicitados os objetivos do estudo, o papel central de cada indivíduo no grupo e sobre o consentimento informado. Também é importante ressaltar o significado central de cada participante e o valor de cada pessoa para o grupo (PALIBRODA et al., 2009).

As enfermeiras obstétricas foram estimuladas a tirar fotografias de situações que serviram para educar, sensibilizar e compreender os temas que permeiam a atuação profissional e os desafios enfrentados por essas profissionais no cotidiano. É importante ressaltar que elas estiveram dispostas e interessadas em trabalhar a mudança a longo prazo, compartilhar abertamente suas experiências com o grupo participante e, eventualmente, com o público.

Os participantes ficaram uma semana com a máquina fotográfica e isso possibilitou a captura de fotografias e imagens. Não houve um limitador para o número de fotografias. Foram capturadas uma média de nove fotografias por participante, com quatro fotografias como número mínimo e vinte, o número máximo. Foi solicitado que as enfermeiras obstétricas identificassem as fotografias, respondendo às perguntas norteadoras:

1) Como você percebe a atuação da Enfermeira Obstétrica no seu trabalho?

2) Quais as facilidades e dificuldades enfrentadas no seu ambiente de trabalho?

\subsubsection{Encontros grupais do Photovoice}

Seres humanos tem a necessidade de entender e explicar o universo em que vivem. Este conhecimento se dá mediante uma relação estabelecida entre um sujeito e determinado objeto, em que se apresenta de forma desordenada e oferece diversas impressões que podem ser captadas pelo sujeito sob diversas perspectivas. Torna-se importante ter 
sempre um ponto de referência: um referencial teórico-metodológico estabelecido, que delineie o campo de observação e determine as condições de relacionamentos entre os fenômenos (GUALDA et al., 1995).

Entre as técnicas da abordagem qualitativa, este estudo vai destacar a do grupo focal, fazendo parte do Photovoice, por ter sido internacionalmente usada para estruturar as ações em saúde pública, tendo como premissas o comportamento, seu significado e sua importância na compreensão de temáticas em grupos (CARLINI-COTRIM, 1996).

Para Gualda et al. (1995), o grupo focal possibilita a construção de um conhecimento coletivo do grupo. O grupo focal pode ser considerado uma espécie de entrevista de grupo. Sua essência consiste em apoiar a interação entre seus participantes para colher dados que se originam de tópicos que são fornecidos pelo pesquisador. O grupo é formado por quatro a doze participantes não familiares uns aos outros e selecionados por apresentarem certas características em comum, relacionadas com os objetivos deste estudo.

O Photovoice foi sugerido por Wang (1999) com sete a dez participantes como tamanho ideal, pois são suficientes para que cada pessoa possa contribuir de uma forma significativa na troca de experiências e ideias, de forma eficaz, além de alimentar um sentimento de compromisso entre as pessoas. Nesta fase do estudo, obtive-se a participação de dez enfermeiras obstétricas.

\subsubsection{Coleta de dados}

A coleta de dados no Photovoice é um processo contínuo e gera uma grande quantidade de dados. A fase de coleta inicia-se com a execução da pesquisa e continua até a fase de compartilhamento das fotografias, seguida da análise dos dados (PALIBRODA et al., 2009). 
Para esta etapa utilizou-se seis máquinas fotográficas digitais com flash e equipadas com cartão de memória para armazenamento das fotografias. Após a utilização por um sujeito, as imagens produzidas foram armazenadas em um computador da pesquisadora e apagadas do dispositivo de armazenamento para assim iniciar um novo ciclo para outro sujeito.

\subsubsection{Análise de dados}

Embora a coleta e análise de dados sejam atividades distintas, há uma sobreposição nestas atividades, ambas ocorrendo simultaneamente.

Seguida da retirada das fotografias, inicia-se a fase de análise dos dados, com a seleção das fotografias que representam fielmente os objetivos propostos, que podem contextualizar a realidade social de cada profissional. Elas devem ser categorizadas para discussão em grupo (PALIBRODA et al., 2009).

Para o encontro, as fotografias foram analisadas pela pesquisadora e separadas entre fatores que facilitam e dificultam o exercício profissional da enfermeira obstétrica. Diante das temáticas apresentadas pelas enfermeiras, as fotografias foram apresentadas e a discussão foi estimulada. A pesquisadora atuou como moderadora e criou um ambiente que facilitou e propiciou que as diferentes percepções e pontos de vista transcorressem sem pressões em seus participantes.

A reunião aconteceu em dezembro de 2015 em um local de fácil acesso, seguro e confortável e em horário combinado com os participantes. Foi utilizada uma sala ampla, confortável, livre de ruídos, com cadeiras e um projetor data-show. A reunião em grupo favoreceu o sentido de compromisso. Os participantes conseguiram observar os pontos fortes de cada um, aprender com os outros, compartilhar as competências individuais e 
melhorar a comunicação interpessoal. O áudio foi capturado por três gravadores (Gravador Iphone 6 plus, Iphone 4s e Ipod Touch 5) com a finalidade de captar os depoimentos dos participantes durante a discussão das fotografias. Subsequentemente, as falas foram transcritas.

O encontro do grupo focal teve duração de 2 horas. Para favorecer a interação social entre as enfermeiras foi oferecido um jantar que oportunizou maior interação e conhecimento entre os participantes. As despesas foram custeadas pela pesquisadora. A sala foi montada com as mesas formando um $\mathrm{U}$, cujo centro foi o ponto de projeção das fotografias. Esta medida oportunizou que todos, ao mesmo tempo, pudessem ser vistos e visualizassem as fotografias projetadas.

Os dados foram analisados por meio de categorias que emergiram e foram identificadas ao longo do discurso, durante o encontro com as enfermeiras obstétricas.

\subsubsection{Preparando e compartilhando a exposição do Photovoice}

Após a fase de coleta e análise de dados, é necessário iniciar os trabalhos para preparar e compartilhar todos os dados que emergiram. As discussões realizadas são determinantes para definir os dados da pesquisa e podem influenciar as políticas públicas.

Logo, esta fase deve ser marcada pela elaboração de projetos, eventos midiáticos e apresentações públicas. As imagens oferecem uma visão mais segura da realidade da comunidade marginalizada, de suas vivências e experiências. 


\subsubsection{Ação social e mudanças nas políticas}

Os resultados alcançados pelo Photovoice enfatizam as ações sociais, uma vez que estas ações são escolhidas para proporcionar mudanças reais na comunidade, já que retratam a realidade de grupos marginalizados. As fotografias e os textos que emergirem dos encontros, possibilitarão a tomada de decisão dos governantes e o surgimento de novas políticas e programas (PALIBRODA et al., 2009).

As políticas públicas são desenvolvidas e planejadas para manter o bemestar de todos os membros da população, de forma coletiva e atingindo os indivíduos também na individualidade, mas dificilmente atingem os objetivos em sua totalidade, por não conseguirem proporcionar oportunidades a todas as pessoas e principalmente pelo fato de cada indivíduo possuir necessidades próprias (PALIBRODA et al., 2009).

Desta forma, as políticas públicas mudam à medida que ocorrem alterações em nossa sociedade e o Photovoice possibilita uma influência nestas questões uma vez que transmitem as mudanças necessárias a um nível comunitário de base, de forma singular (PALIBRODA et al., 2009).

A proposta da pesquisadora para esta etapa se refere ao encaminhamento dos resultados para os serviços de saúde, para revistas científicas e gestores municipais.

\subsection{Aspectos éticos}

A pesquisa foi aprovada pelo Comitê de Ética em Pesquisa da Escola de Enfermagem de Ribeirão Preto da Universidade de São Paulo através do Processo $\mathrm{n}^{\circ}$ 
183/2015 (Anexo). Foi elaborado um Termo de Consentimento Livre e Esclarecido - TCLE (Apêndice B), para ser entregue aos participantes.

As enfermeiras que foram convidados foi apresentado o Termo de Consentimento Livre e Esclarecido (Apêndice B), conforme determina a Resolução 466/2012, do Conselho Nacional de Saúde (BRASIL, 2013a).

Para a realização do registro das imagens (fotografias), foi elaborado um Termo de Uso de Imagem (Apêndice C), ficando este em conjunto com o TCLE. Neste documento, ficou explicado que não haveria exposição dos rostos das pessoas no momento da divulgação dos resultados. Na apresentação dos resultados, tanto os sujeitos da pesquisa quanto as instituições receberam nomes fictícios.

Todas as recomendações que compõem a Resolução 466/12 do Conselho Nacional de Saúde foram seguidas e respeitadas (BRASIL, 2013a).

\subsection{Análise dos dados}

Para análise e interpretação dos dados optou-se por utilizar a técnica de análise de conteúdo proposto por Bardin (2009), descrita por Minayo (2006), utilizando a lente da Antropologia Interpretativa apresentado por Geertz (2006).

Esta técnica tem como elo principal a sistematização do conteúdo, pelo qual se chega a indicadores que possibilitam a inferência dos conhecimentos. Este tipo de técnica vai adiante da denominação de procedimentos técnicos, é parte de uma busca teórica no que tange às investigações sociais (MINAYO, 2006).

A análise de conteúdo será dividida em três fases, a saber (BARDIN, 2009): 
a) Pré-análise

Nesta fase, o pesquisador faz uma leitura ondulante, por meio da qual se estabelece o primeiro contato com os documentos a serem analisados, deixando-se tomar contato exaustivo com o material. O investigador faz a escolha dos documentos, ou seja, procede à demarcação do universo sobre o qual se procederá à análise, portanto constituindo conjunto de documentos obtidos para serem submetidos aos procedimentos analíticos. Ainda nesta fase, podem-se formular hipóteses e objetivos. Já os objetivos poderão ser aqueles que norteiam a investigação ou estabelecidos nesta fase. Seguindo os procedimentos da préanálise, recomenda-se que se determinem, também, as operações de recorte em unidades comparáveis de categorização para análise temática e de modalidade de codificação para o registro dos dados obtidos.

\section{b) Exploração do material}

Ocorre logo após a pré-análise e trata-se de uma fase de operações de codificação, enumeração, classificação e agregação. Nesta etapa o material é codificado e agregado em unidades, as quais permitem uma descrição das características pertinentes do conteúdo. Para a organização da codificação são necessárias três escolhas: o recorte (escolha das unidades), a enumeração (escolha das regras de contagem) e a classificação e a agregação (escolha das categorias). Para proceder com o recorte do material, serão necessárias a leitura e a demarcação dos "núcleos de sentido". Após o recorte, ao invés de proceder à contagem das unidades de significação, a classificação e agregação em categorias será o significado, permitindo uma próxima fase denominada interpretativa, sem se preocupar em realizar inferências. 
c) Tratamento dos resultados, inferência e interpretação

Nesta fase, os resultados brutos são tratados de maneira a serem significativos e válidos. Diante de dados significativos, o investigador poderá propor inferências e interpretações a propósito dos objetivos previstos.

No que tange aos dados visuais, buscou-se descrever o conteúdo desvelado nas fotografias, assim como o significado que elas trazem.

Os dados obtidos (entrevistas individuais e grupo focal) foram armazenados em um computador próprio para a pesquisa. Utilizou-se o software ATLAS ti ${ }^{\circledR}$ para a organização dos depoimentos e imagens coletadas, facilitando assim a categorização. Desta forma, o software foi utilizado apenas para auxiliar no arranjo das falas e imagens, a fim de substituir o papel, colaborando para o acesso imediato das informações.

A seguir, serão apresentados os dados do estudo bem como as reflexões e análises que afloraram no processo, objetivando compreender o tema proposto e seus propósitos. 
RESULTADOS E DISCUSSÃO 


\section{RESULTADOS E DISCUSSÃO}

Os resultados deste estudo serão apresentados em duas etapas: 1) Conhecendo os participantes do estudo, contemplando as entrevistas iniciais realizadas com as vinte enfermeiras obstétricas, e 2) Análise das entrevistas, que contempla os resultados obtidos com a metodologia do Photovoice no grupo focal, com a participação de dez enfermeiras obstétricas.

\subsection{Conhecendo os participantes do estudo}

Participaram deste estudo vinte enfermeiras obstétricas exclusivamente do sexo feminino. A idade das participantes variou de 27 a 52 anos de idade; a variação do tempo de formação foi de 5 a 30 anos e o tempo de atuação na atenção materna foi de 2 a 26 anos.

Para proporcionar melhor compreensão dos contextos nos quais as enfermeiras obstétricas se inseriram, é apresentada, a seguir, uma caracterização de cada uma delas, conforme roteiro de entrevista (Apêndice A). Para garantia do sigilo com relação à identidade das enfermeiras obstétricas, foram atribuídos nomes fictícios.

\section{Cleo}

É enfermeira formada há 27 anos, tem 47 anos de idade, é divorciada e tem um filho. Realizou a especialização em Enfermagem Obstétrica há 15 anos e cursou outras duas especializações: Educação em Saúde e Regulação em Serviços de Saúde. Fez um curso de atualização em Terapia Comunitária. Trabalha na atenção materna há 21 anos, tendo 
atuado em hospital geral antes de trabalhar na saúde da mulher. Atualmente trabalha na instituição Estrela.

\section{Maria}

É enfermeira formada há 26 anos, tem 48 anos de idade, é casada e tem três filhos. Realizou a especialização em Enfermagem Obstétrica há 16 anos e cursou outras duas especializações: Enfermagem em Saúde Pública e Enfermagem em Educação em Saúde. Trabalha na atenção materna há 26 anos, tendo trabalhado na saúde pública antes de iniciar na saúde da mulher. Atualmente trabalha na instituição Estrela.

\section{Clara}

É enfermeira formada há 25 anos, tem 49 anos de idade, é casada e tem dois filhos. Realizou a especialização em Enfermagem Obstétrica há 25 anos e cursou mais duas outras especializações: Administração Hospitalar e Docência em Enfermagem. Fez cursos de aprimoramento em neonatologia, cuidados em obstetrícia e de doula. Há 25 anos trabalha na área da atenção materna. Atuou como enfermeira na ala de adultos antes de chegar na saúde da mulher. Atualmente trabalha na instituição Estrela.

Joana

É enfermeira formada há 13 anos, tem 43 anos de idade, é solteira, não tem filhos. Realizou especialização em Enfermagem Obstétrica há 2 anos, cursou ainda a especialização em Urgência e Emergência em Enfermagem, Enfermagem do Trabalho e Gestão em Saúde. Possui outra graduação incompleta em Pedagogia. Trabalha há três anos na atenção materna. Atuou na saúde da família e como docente antes de trabalhar na saúde da mulher. Atualmente trabalha na instituição Estrela. 
Lia

É enfermeira formada há 23 anos, tem 46 anos de idade, é casada e tem três filhos. Realizou especialização em Enfermagem Obstétrica há 14 anos e outra especialização em Regulação em Serviços de Saúde. Trabalha na atenção materna há 13 anos. Trabalhou na saúde pública antes de atuar diretamente na saúde da mulher. Atualmente trabalha na instituição Estrela.

Julia

É enfermeira formada há 23 anos, tem 47 anos de idade, é casada e tem dois filhos. Concluiu a especialização em Enfermagem Obstétrica há 15 anos e cursou outra especialização em Auditoria em Saúde. Trabalha na atenção materna há 22 anos. Atuou na saúde pública antes de trabalhar na saúde da mulher. Atualmente trabalha na instituição Estrela.

\section{Luiza}

É enfermeira formada há 30 anos, tem 52 anos de idade, é casada e tem um filho. Realizou a especialização em Enfermagem Obstétrica há 15 anos e cursou mais três especializações: Auditoria em Saúde e Metodologia da Pesquisa. Realizou cursos de aperfeiçoamento na área de urgência e emergência. Trabalha na atenção materna há 22 anos. Trabalhou em um hospital geral antes de iniciar a assistência na saúde da mulher. Atualmente trabalha na instituição Estrela.

\section{Beatriz}

É enfermeira formada há 24 anos, tem 49 anos de idade, é casada e tem dois filhos. Realizou a especialização em Enfermagem Obstétrica há 14 anos, cursou outras duas 
especializações: Regulação dos Serviços de Saúde e Aconselhamento em Aleitamento Materno. Possui mestrado em Gestão de Serviços de Saúde. Realizou cursos de aperfeiçoamento nas áreas de urgência e emergência em enfermagem. Trabalha na área da saúde da mulher há 23 anos. Atuou em hospital geral antes de trabalhar na saúde da mulher. Atualmente trabalha na instituição Estrela.

\section{Ester}

É enfermeira formada há 29 anos, tem 52 anos de idade, é solteira e não tem filhos. Realizou especialização em Enfermagem Obstétrica há 25 anos, tendo cursado também especialização em Urgência e Emergência em Enfermagem. Trabalha na atenção materna há 22 anos. Atuou como docente em curso técnico de enfermagem e em hospital geral antes de trabalhar na saúde da mulher. Atualmente trabalha na instituição Estrela.

\section{Renata}

É enfermeira formada há seis anos, tem 29 anos de idade, é casada e tem um filho. Realizou especialização em Enfermagem Obstétrica há seis anos. Trabalha na atenção materna há quatro anos. Sempre atuou como enfermeira na saúde da mulher. Atualmente trabalha na instituição Água.

\section{Stela}

É enfermeira formada há sete anos, tem 36 anos de idade, é casada e não tem filhos. Realizou especialização em Enfermagem Obstétrica há sete anos e atualmente cursa uma nova graduação em Estética e Cosmética. Trabalha na atenção materna há cinco anos. Iniciou sua atuação como enfermeira em uma ala de cuidados com adultos, mas logo foi direcionada para a maternidade. Atualmente trabalha na instituição Água. 


\section{Rogéria}

É enfermeira formada há sete anos, tem 36 anos de idade, é casada e tem um1 filho. Concluiu a especialização em Enfermagem Obstétrica há sete anos. Trabalha na atenção materna há sete anos. Sempre atuou como enfermeira na saúde da mulher. Atualmente trabalha na instituição Água.

\section{Caroline}

É enfermeira formada há nove anos, tem 30 anos de idade, é casada e não possui filhos. Realizou a especialização em Enfermagem Obstétrica há nove anos. Fez cursos de aperfeiçoamento na área de Aleitamento Materno e de Interpretação de ECG. Trabalha na atenção materna há nove anos. Sempre atuou como enfermeira na saúde da mulher. Atualmente trabalha nas instituições Estrela e Lua.

\section{Rose}

É enfermeira formada há oito anos, tem 29 anos, é solteira e não tem filhos. Concluiu a especialização em Enfermagem Obstétrica há sete anos. Atualmente cursa Mestrado em Enfermagem. Trabalha na atenção materna há sete anos. Sempre atuou com enfermeira na saúde da mulher. Atualmente trabalha como docente e na instituição Lua.

\section{Gabriela}

É enfermeira formada há nove anos, tem 31 anos, é solteira e não tem filhos. Possui uma segunda graduação em Administração Hospitalar e duas especializações, nas áreas de Urgência e Emergência e Pré-Natal. Concluiu o Mestrado em Ciências, na área da Saúde da Mulher. Trabalha na área da saúde da mulher há nove anos. Sempre atuou como enfermeira na saúde da mulher. Atualmente trabalha como docente e na instituição Lua. 


\section{Bruna}

É enfermeira formada há nove anos, tem 31 anos, é casada e tem dois filhos. Realizou a especialização em Enfermagem Obstétrica há seis anos. Fez curso de aperfeiçoamento em Aleitamento Materno. Trabalha na área materna há dois anos. Atuou em outros trabalhos fora da enfermagem até chegar na saúde da mulher. Atualmente trabalha na instituição Sol.

\section{Carla}

É enfermeira formada há 13 anos, tem 38 anos de idade, é casada e tem um filho. Realizou a especialização em Enfermagem Obstétrica há 12 anos, cursou outra especialização, em Unidade de Terapia Intensiva. Trabalha na área atenção materna há sete anos. Atuou como enfermeira em um hospital geral antes de atuar na área da saúde da mulher. Atualmente trabalha na instituição Sol.

\section{Denise}

É enfermeira formada há cinco anos, tem 27 anos de idade, é solteira e não tem filhos. Concluiu a especialização em Enfermagem Obstétrica há seis anos. Fez curso de aperfeiçoamento em Aleitamento Materno. Trabalha na atenção materna há um ano. Atuou como cuidadora domiciliar e em um hospital geral antes de trabalhar na saúde da mulher. Atualmente trabalha na instituição Sol.

\section{Eva}

É enfermeira formada há sete anos, tem 30 anos de idade, é casada e tem um filho. Concluiu a especialização em Enfermagem Obstétrica há sete anos, cursou outra especialização, na área de Urgência e Emergência em Enfermagem. Trabalha na atenção 
materna há três anos. Sempre atuou na saúde da mulher. Atualmente trabalha na instituição Sol.

Gisele

É enfermeira formada há oito anos, tem 40 anos de idade, é solteira e tem um filho. Concluiu a especialização em Enfermagem Obstétrica há seis anos. Fez cursos de Aprimoramento em aleitamento materno e Cuidados para pacientes em alto risco e puerpério. Trabalha na atenção materna há 14 anos, atuando sete anos como auxiliar e técnica de enfermagem. Como enfermeira sempre atuou na saúde da mulher. Atualmente trabalha na instituição Sol.

\subsection{Análise da entrevista}

Os discursos das participantes apresentaram aspectos únicos, que evidenciaram suas percepções singulares sobre o significado da assistência da enfermeira obstétrica no cenário da admissão, pré-parto, parto e pós-parto imediato.

\subsubsection{O significado da assistência da enfermeira obstétrica no cenário da admissão, pré- parto, parto e pós-parto}

No desenvolvimento desta etapa, foram utilizados dados emanados no momento da entrevista individual em resposta à seguinte questão: $\mathrm{O}$ que significa para você trabalhar na admissão, pré-parto, parto e pós-parto imediato? 
Após reorganização dos conteúdos que emergiram das entrevistas, ocorreu o agrupamento das unidades por semelhança de conteúdo, constituindo assim a fase de categorização. Nesta fase, após o tratamento dos dados, as categorias resultantes do conteúdo da entrevista individual foram: a) Acolhimento e vínculo: cuidados assistenciais que transmitem segurança à parturiente; b) Autonomia na enfermagem obstétrica: percepções da prática assistencial e c) Sentimentos emanados na atuação da enfermeira obstétrica nos cenários de admissão, pré-parto, parto e pós-parto imediato.

\subsubsection{Acolhimento e vínculo: cuidados assistenciais que transmitem segurança à parturiente}

As enfermeiras obstétricas descreveram que o acolhimento foi o principal significado atribuído para o momento da admissão, do pré-parto, parto e pós-parto imediato. Os relatos trouxeram o acolhimento como uma experiência marcante, que transmite tranquilidade e desmistifica o cuidado, sendo traduzido como o primeiro contato com a paciente, como momento de orientação e fundamental para criar vínculo. A importância do acolhimento e do vínculo como recurso do cuidado é que pode levar segurança à mulher no momento do parto, pois, segundo Souza et al. (2010), a parturiente, quando se sente realmente apoiada, quando o vínculo acontece, ela se sente tranquila, confiante e segura.

O acolher é dar acolhida, aceitar, dar ouvidos, dar créditos, receber, atender, admitir. O acolhimento é um ato de aproximação, é uma atitude de inclusão. É prestar um serviço digno, humano; é atender de forma responsável e com resolutividade (BRASIL, 2010b). 
Neste sentido, Machado e Praça (2006) consideram que o cuidado prestado à parturiente no momento da admissão precisa ser centrado não somente em procedimentos e normas técnicas, mas no significado da individualidade, pois o ser humano é diferenciado por natureza e nasceu com características próprias, as quais devem ser respeitadas, consideradas e valorizadas.

É importante o acolhimento, a admissão da paciente, para você ter uma ideia de como vai trabalhar com esta paciente. Apesar de você ter uma rotina de serviço, cada paciente é única, e cada uma tem o seu problema e a sua particularidade... (Cleo).

O acolhimento é essencial, primeiro vínculo, é a troca de informações... (Renata).

$O$ acolhimento é o primeiro contato, é o momento de deixar a gestante segura... (Rogéria).

Eu acho o acolhimento a base de tudo (...), é o primeiro contato, é a troca de confiança... (Denise).

Para Schimith e Lima (2004), o conceito de acolhimento é construído com base nos princípios éticos, no respeito à diversidade e na tolerância aos diferentes, baseado na escuta clínica comprometida com a cidadania. O acolhimento se dá na união entre o profissional e o usuário, em que o primeiro procura desvelar as necessidades do segundo ao longo de uma relação negociada e se constrói o vínculo. 
O rompimento do cenário de atenção pré-natal e o surgimento do cenário da atenção na admissão e pré-parto são marcados por incertezas e medos, pois inicia-se uma nova relação de vínculo com uma equipe muitas vezes desconhecida. Nesta fase, ser acolhida significa ter tranquilidade para enfrentar os desafios que surgirão no momento do pré-parto e parto e nos cuidados com a nova vida que está para chegar.

A mulher, quando se entrega à equipe de saúde, passa a ser cuidada por desconhecidos, o que muitas vezes a deixa impedida de participar de forma eficaz da experiência. Ao adentrar o hospital, a naturalidade do pré-parto e do parto são muitas vezes interrompidas por normas e rotinas a serem cumpridas, indo contrário à espontaneidade e intimidade necessários para dar à luz (BERLINGUER, 1996; BRASIL, 2014a).

O hospital/maternidade, por melhor que possa prestar a assistência, é um ambiente estranho para a parturiente, sua família e seu acompanhante, podendo gerar angústias, medos, ansiedade, insegurança e outros sentimentos (MALDONADO, 1997).

Na admissão, o acolhimento é de extrema importância, pois a gestante faz o pré-natal com outra equipe, então temos que conhecer a paciente, criar o vínculo e fazer uma abordagem acolhedora para que ela se sinta segura na nova equipe... (Beatriz).

(...) quando a mulher sabe de tudo o que vai acontecer com ela conseguimos tomar as melhores decisões, devido ao relacionamento previamente adquirido no momento do acolhimento, ganhamos a sua total confiança... (Gabriela). 
Ainda neste contexto, a conduta profissional é de ampla relevância no cuidado à parturiente, pois além da utilização dos cuidados específicos que podem ser realizados, há a necessidade de uma abordagem empática a fim de aliviar a dor tanto presente nas parturientes e intensificada pelas relações interpessoais na interação profissionalparturiente-família. Com a acolhida dos profissionais e a adoção dos cuidados, o processo de trabalho de parto e parto poderá ser mais ameno, menos doloroso e mais tranquilo, dado que as parturientes necessitam de atenção, acolhimento e vínculo (DAVIM et al., 2008).

No que tange à humanização da assistência ao parto, é fundamental para a parturiente sentir-se segura; para tanto, é necessário que a equipe ofereça apoio durante o período de parturição, proporcionando assim o cuidado, o conforto e a segurança à paciente e seu acompanhante. Desta forma, ao estar presente neste momento, é possível ouvir seus medos, angústias e anseios (CARRARO et al., 2013; DODOU et al, 2014).

É um procedimento delicado tanto para a paciente como para mim, pois ambas não se conhecem e podem se sentir invadidas, então eu tento "pescar" as informações para criar um vínculo com a mãe... (Julia).

Faz toda diferença a maneira como você aborda, como é tratada, tem que sentir segurança, o lado humano (...) é o momento de tirar as angústias, os medos e a insegurança. $O$ acolhimento é fundamental... (Eva)

O cliente, neste estudo representada pela parturiente, é frágil e espera encontrar na enfermeira obstétrica que a assiste uma pessoa forte e, de certa forma, sensível, preparada para a atuação nas diversas fases até o nascimento, que possa acolhê-la e ampará-la 
nos momentos de dor, assistindo em um trabalho de parto que pode ser demorado e desgastante ou rápido e sem intercorrências.

O acolhimento é um modo de operar os processos de trabalho em saúde ao atender a todos que procuram os serviços de saúde, ouvindo seus pedidos e assumindo uma postura capaz de acolher, escutar e pactuar respostas mais adequadas aos usuários. O acolhimento não é um espaço ou um local, mas uma postura ética, não pressupõe hora ou profissional específico para fazê-lo e implica compartilhamento de saberes, necessidades, possibilidades, angústias e intenções (BRASIL, 2014a).

É importantíssimo o acolhimento para dar orientações para paciente, tirar medo, ansiedade, dúvidas, principalmente mães primigestas que não sabem o que esperam, que ficam nervosas, ansiosas, o acolhimento faz com que tenhamos mais vínculo com a parturiente (...) o nosso papel é ir lá, dar apoio, confortar, orientar... (Joana).

$O$ acolhimento é primordial, é o momento de coletar o histórico, medos, traumas, uma conversa para podermos entender quais as perspectivas da paciente, o tipo de parto que preferem, explicarmos qual a melhor opção... (Caroline)

Frente a esta temática, as atitudes e ações geradas no acolhimento estão relacionadas a uma mudança na cultura hospitalar, ou do ambiente onde será o nascimento, com a assistência médica e de enfermagem voltadas para as reais necessidades das mulheres e suas famílias, realizando alterações na estrutura física, modificando o espaço hospitalar ou 
domiciliar em um ambiente mais acolhedor e benéfico para implantação de práticas humanizadoras da assistência (DIAS; DOMINGUES, 2005).

Uma vez que o parto foi levado para dentro dos hospitais nas primeiras décadas do século XX, a assistência deixou de ser prestada no ambiente familiar, centralizado em modelo feminino de atenção. O MS vem tentando resgatar o sentido humano do parto, adotando várias medidas para a melhoria das condições estruturais (STANCATO et al., 2011).

Assim, em 03 de junho de 2008, a Agência Nacional de Vigilância Sanitária (ANVISA) editou a Resolução da Diretoria Colegiada 36 (RDC) para normatizar e padronizar o funcionamento dos serviços de atenção obstétrica e neonatal, pretendendo sistematizar e qualificar a gestão, humanizar e harmonizar a assistência prestada ao parto, do mesmo modo que objetivou reduzir riscos aos usuários e ao meio ambiente (BRASIL, 2008).

Neste sentido, a RDC 36/2008 apresenta, como padrão normativo, conceitos, condições organizacionais, infraestrutura física, recursos humanos, materiais e equipamentos, acesso a recursos assistenciais, processos operacionais, transporte de pacientes, prevenção e controle de infecção, biossegurança, notificação de eventos adversos graves, descarte de resíduos e avaliação (BRASIL, 2008). Observamos nos relatos das participantes deste estudo a falta de estrutura adequada, o que dificulta o acolhimento no momento da internação da parturiente e no seu seguimento, uma vez que ter condições de infraestrutura adequada é um fator facilitador para a assistência de qualidade e humanização do atendimento, corroborando a normativa proposta pela ANVISA.

A sala de atendimento não é muito confortável e não temos muito espaço para privacidade... (Carla). 
Faço o possível para acolher no momento da admissão, sei que é muito importante, mas nem sempre eu consigo, porque a estrutura física não ajuda, não tem chuveiro decente, as instalações são apertadas (...) deveria ser um ambiente mais tranquilo... (Ester).

Gosto mais de atuar nos consultórios, na admissão. Não tenho muito tempo de interagir com a parturiente, pois cuido de todo setor, da parte burocrática. Tenho que preencher documentos e coletar exames, não sobra tempo para outras atividades, mas eu gostaria de ter mais tempo... (Stela).

Faço todo procedimento sozinha e quando o hospital tá lotado, a infraestrutura não é adequada, não dá muito para acompanhar a paciente... (Joana).

Não temos estrutura para o atendimento especializado à parturiente e aprimorarmos o atendimento, esta dificuldade se tem pelo fato de ser um hospital privado (...) Não posso colocar em prática tudo o que aprendi... (Rogeria).

A percepção do acolhimento pelas enfermeiras obstétricas participantes do estudo destaca também a presença do acompanhante como um cuidado indispensável em todo 
processo de parturição, que dever ser estimulado por todos, não havendo relatos de dificuldades ou problemas na inserção dele no cenário do nascimento.

Para a OMS, os profissionais de saúde devem acolher a parturiente e serem capazes de realizar, além das atividades essenciais e procedimentos técnicos, o apoio necessário para aquele momento, fazendo-se valer de intersubjetividade na relação do cuidado e, principalmente, fornecendo orientações para o acompanhante (OMS, 1996).

A participação do acompanhante transmite segurança e conforto em um momento em que há medo e solidão. Dessa forma ele aparece com um significado emocional, pois gera satisfação e tranquilidade, interferindo de modo positivo no desenrolar do parto (NAKANO et al., 2007).

No momento da admissão a gente já explica para o acompanhante, tem bola, tem o chuveiro, tem banquinho. A presença do acompanhante melhora muito a humanização do atendimento, ela se sente mais segura... (Maria).

Quando você se identifica para a paciente e para o acompanhante, tira suas dúvidas, você vê que eles ficam mais tranquilos, o acompanhante, quando é acolhido, ajuda bastante na assistência e tudo fica mais calmo e seguro... (Carla).

O papel de educadores exercido pelas enfermeiras obstétricas na condução do acompanhante escolhido pela parturiente é fundamental para o sucesso desta relação, transmitindo confiança para a parturiente, minimizando o medo do desconhecido e valorizando a presença dele. Esta interação entre o acompanhante do parto e os profissionais 
de saúde deve iniciar no pré-natal, em um momento de preparação dos familiares, antes de serem introduzidos no cenário da maternidade.

Acho muito importante o acompanhante, pois ajudam o tempo todo e quando são orientados, somam com a equipe da enfermagem $e$ transmite tranquilidade para a parturiente... (Joana).

Hoje em dia orientamos a liberdade de caminhar e do direito de ter acompanhante. Quando ele é presente, facilita muito... (Renata)

A deficiência da assistência no atendimento pré-natal foi relacionada pelas enfermeiras obstétricas como uma fragilidade para se ter o acolhimento, fato que se deve ao número reduzido de consultas, a falta de exames laboratoriais preconizados pelo MS e pela falta de informações sobre o processo de parir. O primeiro contato no atendimento à parturiente é fundamental para o estabelecimento da confiança entre o profissional que presta a assistência e a paciente.

A assistência pré-natal integral e completa é um fator de proteção indispensável para saúde materna e neonatal, por conter procedimentos considerados rotineiros, preventivos e curativos e de promoção de saúde. Desta forma, o pré-natal, quando bem conduzido pelos profissionais de saúde, pode evitar e contornar problemas obstétricos, prevenir diversos danos e promover o nascimento saudável (COSTA et al., 2016).

A falta ou assistência inadequada durante o pré-natal podem trazer graves danos e consequências para a saúde da gestante e do feto. Vários estudos demonstram que as 
gestantes que frequentaram o pré-natal apresentam números menores de complicações na gestação e parto e os fetos crescem saudáveis e nascem com peso adequado para a idade gestacional (PARIS et al., 2013; NASCIMENTO et al., 2008; RASIA; ALBERNAZ, 2008; SHIMIZU; LIMA, 2009; PEDRAZA et al., 2013).

Para a promoção da maternidade segura é necessário que ocorra uma atenção pré-natal qualificada, em que os profissionais que prestam a assistência tenham conhecimentos e habilidades específicos, baseando-se em fundamentos de fisiologia presentes no ciclo gravídico-puerperal em conjunto com aspectos socioculturais das mulheres (NARCHI, 2010; ALVES et al., 2015).

O que acontece aqui muito é que as pacientes têm um prénatal mal feito, então o atendimento acaba sendo uma caixinha de surpresas, porque dificulta um melhor entrosamento com a paciente... (Ester).

Então a gente vai perguntar pra ela sobre o pré-natal dela, como foi tudo e vemos muitas deficiências (...) a questão do pré-natal é pra gente saber como lidar, o que é mais importante, uma doença prévia, ou algo que não foi realizado e que achamos importante... (Cleo).

A maior dificuldade no acolhimento realizado na admissão é quando o pré-natal não foi bem realizado, quando faltam informações, exames (...), aí você para tudo para saber que caminho vai fazer, pois nem sempre vai conseguir fazer tudo... (Clara). 
Sabe-se que, apesar da implantação de políticas para melhoria na atenção pré-natal, com um aumento no número de consultas por mulheres, a qualidade da assistência ainda está comprometida, de acordo com auditoria realizada nos cartões de pré-natal. As informações contidas nesses cartões permitem a visualização do atendimento das necessidades das gestantes, seu acesso aos serviços de referência, refletindo assim nos indicadores de mortalidade materna e infantil de forma direta, pois acredita-se que se o procedimento não foi registrado, ele não foi realizado (BARROS et al., 2012; SANTOS NETO et al., 2012).

Os discursos encontrados pelas participantes deste estudo sinalizam para a falta de qualidade na assistência pré-natal, porque precisam completar as etapas não vivenciadas na atenção pré-natal e desta forma demoram para criar o vínculo e iniciarem o acolhimento necessário para a atenção ao pré-parto e parto.

Quando ela chega aqui na admissão sem saber informações sobre o parto é muito ruim, porque demoramos para criar o vínculo, pois geralmente ela está com dor e angustiada e não tem muita paciência de escutar, não responde corretamente as solicitações... (Beatriz).

Toda paciente que é internada a enfermeira vai conhecer a paciente, primeiro você observa o cartão da gestante, se está tudo certinho, se tem alguma intercorrência, mesmo assim, conversamos com ela, se ela teve alguma intercorrência que não está marcada no cartão, sempre falta alguma coisa do pré-natal e dificulta o atendimento inicial... (Maria) 
É importante salientar que a assistência de enfermagem deficiente no prénatal traduz um complicador para o atendimento no cenário do parto e nascimento, principalmente na admissão do período pré-parto, aumentando assim a ansiedade e medo, pois é durante o atendimento no pré-natal que os profissionais devem explorar a vida das gestantes, isto é, sua cultura, sua história, reconhecer seu contexto, sanar suas dúvidas e desta forma serem ouvidas e orientadas, diminuindo assim os riscos inerentes a esse período e qualificando a assistência prestada.

\subsubsection{Autonomia na enfermagem obstétrica: percepções da prática assistencial}

A autonomia na prática assistencial das enfermeiras obstétricas surgiu nas expressões e nos relatos das entrevistadas como um fator incapacitante que leva à implicação da qualidade na assistência à saúde da parturiente por elas assistida.

A consolidação da profissão de enfermeiro, enfermeira obstétrica e demais profissionais da classe ocorreu com a Lei do Exercício Profissional de Enfermagem, $\mathrm{n}^{\circ}$ 7.498/86, regulamentada pelo Decreto 94.406/87, que dispõe sobre o exercício da enfermagem e dá outras providências. Em seu $6^{\circ}$ artigo, assegura-se que a Enfermeira Obstétrica ou Obstetriz é o titular do diploma ou certificado de Enfermeira Obstétrica ou Obstetriz (inciso II). Entre as atividades de enfermagem descritas no artigo $11^{\circ}$, traz a definição da competência da enfermeira na assistência de enfermagem à gestante, parturiente, puérpera e recém-nascido, cabendo aos profissionais assistir à parturiente e ao parto normal, identificar distócias obstétricas e tomar providências até a chegada do médico, realizar episiotomia e episiorrafia e aplicar anestesia local, quando necessária (BRASIL, 1987). 
Ainda neste sentido, foi publicada a Portaria $n^{\circ} 2.815$ de 29 de Maio de 1998 do MS, incluindo o procedimento parto normal sem distócia realizado por enfermeira obstétrica na tabela do Sistema de Informações Hospitalares do SUS (BRASIL, 1998).

Diante do cenário de legislação favorável ao exercício pleno das atividades assistenciais obstétricas, a realidade encontrada é diferente, apresentando a falta de cultura nas instituições, limitação do conhecimento da legislação sobre o respaldo legal para o exercício profissional pelo poder médico, o acúmulo de atividades e de múltiplas jornadas de trabalho e por falta de conhecimento científico para o manejo do parto (VIEIRA et al., 2013).

As declarações seguintes demonstram o cuidado centrado no poder médico e a falta de autonomia das enfermeiras obstétricas com relação a procedimentos garantidos pela Lei do Exercício Profissional.

Eu acho muito complicado não ter autonomia na instituição para assistir ao parto, só fazemos se o médico não chegar, o médico tem que assinar tudo o que a gente faz, ou mesmo estar junto com você, isso é muito ruim... (Carla).

Aqui na maternidade temos um protocolo, para conduzir partos de baixo risco, mas nunca mudou, mesmo com lei e protocolo, a enfermeira não assume, não temos esta autonomia... (Maria).

Esta questão da atuação da enfermeira ainda não mudou, continua sem autonomia, continua o enfermeiro conduzindo o trabalho de parto, mas ele nunca interna, 
nunca preenche AIH, acho meio complicado a atuação da enfermeira... (Stela).

Aqui não temos autonomia, falta protocolo para definir as funções da enfermeira obstétrica, em casos de baixo risco a enfermeira consegue conduzir tranquilamente, mas sem autonomia é muito complicado, não dá... (Renata).

A autonomia da enfermeira obstétrica em muitos cenários é limitada pela hegemonia médica, conforme relato de várias enfermeiras, marginalizando a especialidade e a atuação dessas profissionais.

Desde os primórdios da profissão, a submissão da enfermeira ao médico foi destacada por Florence Nightingale, cujos treinamentos das futuras enfermeiras baseavam-se na capacidade de executar fielmente ordens médicas e de autoridades. Desta forma a enfermagem profissional foi concebida como uma profissão dependente e subordinada à classe médica (GASTALDO; MEYER, 1989).

Algumas enfermeiras obstétricas entrevistadas manifestaram desejo de executar algumas atividades no cuidado à parturiente, mas, na prática, na maioria das instituições elas somente podem executar tais cuidados com a ciência e a autorização da equipe médica, o que evidencia o modelo médico na assistência.

As maternidades deveriam implantar protocolos assistenciais visando garantir o pleno exercício da atuação da enfermeira obstétrica, com uma descrição clara de suas atribuições, garantindo desta forma a execução da assistência independente da presença do médico, já que a Lei do Exercício Profissional evidencia de forma transparente a prática 
obstétrica da enfermeira especializada, independente da presença de outros profissionais (BARROS et al., 2007).

Quando fiz a especialização, na maternidade as enfermeiras tinham autonomia, abriam partograma, prescreviam medicamentos, aqui não é assim, culturalmente a enfermeira é apenas responsável pela burocracia... (Joana).

Com relação ao atendimento no pré-parto e parto, não temos muita autonomia, o corpo clínico não nos oferece esta autonomia, mas temos liberdade de pedir, muitas vezes eu não faço porque não quero, não sinto vontade... (Luiza).

Analisando o cuidado da enfermeira obstétrica no processo do parto, o poder médico corporativo é muito visível e frequente nos relatos das participantes. É possível verificar nas falas das entrevistadas que existe uma relação de dependência, dominação e submissão, na relação entre médicos e enfermeiras.

A subordinação do trabalho da enfermeira obstétrica na atenção a parturiente no pré-parto é uma situação evidenciada em vários estudos, que mostram que há desigualdades de poder neste cenário (RABELO; OLIVEIRA, 2010). A falta de participação das enfermeiras no processo decisório da assistência ao parto acaba atribuindo ao trabalho destas profissionais uma função instrumental, acessória ao trabalho do médico, como é evidenciado nas falas das profissionais. 
Ainda vivemos em um ambiente de atuação voltado para o médico, precisamos ter uma responsabilidade muito grande, não temos autonomia, não está na cultura da instituição... (Beatriz).

Eu acho complicada esta questão de assumir o cuidado todo no pré-parto, por não ter um colega médico que participe prontamente com você e, de repente, você tem uma intercorrência nesse parto e você não tem o apoio desse profissional... (Cleo).

Muitas vezes fico frustrada, porque não consigo atuar da forma que aprendi na especialização, gostaria de atuar mais na prática, mas não é permitido pelos médicos, não temos autonomia, muitas vezes sei que poderia fazer diferente, fazer uma assistência melhor, mais humanizada... (Rogéria).

As enfermeiras obstétricas prestam um atendimento menos intervencionista e transmitem uma maior satisfação à parturiente no momento do nascimento, gerando maior conforto, respeitando o processo fisiológico, valorizando a sua autoconfiança e garantindo a sua capacidade de parir (REIS et al., 2015).

Trabalho com muita autonomia, hoje faço partos sozinha, com muita confiança e até opino nas decisões médicas (...) no hospital que trabalho tenho autonomia para realizar todos os procedimentos, os médicos confiam, mas isso só depende da vontade de cada um, ter experiência $e$ aprender os processos... (Caroline). 
Hoje os médicos confiam muito nas enfermeiras, essa confiança é gratificante, estudamos e nos aprimoramos cada vez mais, para dar um bom atendimento a essas gestantes, avaliar a paciente, saber conduzir o trabalho de parto, é muita autonomia... é uma conquista... (Bruna).

Na enfermagem, no campo da obstetrícia é bem complexo e bem diferente, você tem que ter autonomia, tem exames que você tem que saber, são várias rotinas (...), com o passar do tempo criei mais confiança, já até fiz alguns partos... (Denise).

No hospital construíram salas de parto mais modernas $e$ temos uma autonomia maior agora (...), eles vem acreditando na enfermeira obstétrica e deixando o trabalho de parto evoluir, confiam na gente... (Eva).

O que facilita meu trabalho é ter confiança e adquirir autonomia e assumir os riscos, isso nos desenvolve e me fez crescer profissionalmente... (Gisele).

Em um contraponto ao cenário descrito acima, percebe-se que a autonomia é muitas vezes conquistada com o conhecimento sobre o assunto, pela cultura da instituição e pela iniciativa da enfermeira obstétrica (VIEIRA et al., 2013). Vários estudos têm demonstrado com evidências científicas que há relação entre o aumento da morbimortalidade materna e perinatal e o modelo intervencionista hegemônico nos diversos cenários da 
assistência, tanto nos modelos públicos quanto privados. Assim, adotar um modelo reduzido de intervenções desnecessárias na atenção ao parto e nascimento pode acarretar a redução da mortalidade materna, viabilizando o alcance das metas do Objetivo de Desenvolvimento do Milênio (REIS et al., 2015; CORTES, et al., 2015).

\subsubsection{Sentimentos emanados na atuação da enfermeira obstétrica nos cenários da admissão, pré-parto, parto e pós-parto imediato}

A expressão das emoções constitui uma habilidade social extremamente importante no convívio social dos indivíduos, pois traduz a causa e efeito quase que imediatamente nas pessoas. As regras definidas para explicitar as emoções ditam de que forma nossos sentimentos refletem em outas pessoas.

A inteligência é compreendida como a habilidade do ser humano em relacionar-se adequadamente com seus pares, sendo capaz de captar estados de humor, perceber seus sentimentos, aspirações, intenções, afetos e desafetos, respeitando a cultura em que está inserido e sendo capaz de avaliar a coletividade sob várias perspectivas diferentes (GOLEMAN, 1995; SOARES, 2001).

As competências emocionais são fundamentais no desenvolvimento das interações sociais porque as emoções sustentam nossas funções comunicativas e sociais, além de trazerem informações sobre os pensamentos e as interações culturais (CARVALHO, 2013). 
No que tange à assistência prestada pelas enfermeiras obstétricas, as emoções assumem especial importância, por ser uma profissional que atua diretamente nas relações humanas, no trato emergencial do nascimento, respeitando o significado singular dos indivíduos e, da mesma forma, atuando na coletividade, na família que surge, devendo assim atuar com capacidade de reconhecer e controlar suas emoções e sentimentos (COSTA; FARIA, 2009).

$\mathrm{Na}$ atuação da enfermeira obstétrica, devemos destacar o atendimento holístico, isto é, compreendendo os fenômenos do nascimento na sua totalidade e globalidade, valorizando desta forma a influência das emoções na evolução física-patológica, mesmo sem saber qual a tendência das enfermeiras, quer dizer, se em sua atuação priorizam o modelo tecnicista ou se comportam de maneira a se dominarem pelos sentimentos quando lidam com a parturiente nos diversos ambientes, como admissão, pré-parto, parto e pós-parto (LEMOS; et al., 2010).

Neste sentido, a enfermeira obstétrica tem a difícil conduta de redefinir sua abordagem terapêutica, uma vez que, para ocorrer o relacionamento terapêutico significativo com outro ser humano, há a necessidade de estar emocionalmente envolvida, pois atua de forma irrestrita, de forma holística.

Ao analisar os sentimentos que emergiram nas entrevistas, ficou evidenciado que a totalidade das enfermeiras obstétricas que atuam nos cenários de admissão, pré-parto, parto e pós-parto imediato sentem-se gratificadas e realizadas quando conseguem prestar uma assistência qualificada e completa, fato este somado ao fato de o desfecho do parto, o nascimento, ocorrer saudável e sem intercorrências. 
A alegria do nascimento foi transmitida na maioria dos relatos como natural e inevitável, pois neste momento há um estreitamento na relação, uma entrega por parte da parturiente, representando a assistência da enfermeira obstétrica mais do que assistência propriamente dita, mais do que cuidar de alguém, um sentimento de preocupar-se com alguém.

O momento do nascimento é fenomenal, fico muito feliz quando conseguimos prestar uma assistência adequada e como resultado ter pai-mãe-filho felizes...é emocionante... (Cleo).

Sinto o momento do pós-parto imediato como um momento de conclusão do meu trabalho, faço tudo para que tudo saia perfeito e para que o bebê cresça corretamente e garanta os cuidados com a mãe, para que a mesma não tenha sequelas, é um momento gratificante... (Clara).

Trabalhar no pré-parto é emocionante, a cada momento acontece uma coisa diferente, nunca é igual, é emocionante você prestar uma assistência $e$ ver o resultado, o nascimento saudável e a mãe saudável, é gratificante... (Joana).

O pós-parto imediato é o meu momento preferido pela gratidão, independente das reações da paciente $e$ circunstâncias do parto, me sinto gratificada e tenho um 
imenso carinho, pois ali está surgindo uma família... (Julia)

É impossível não se envolver com a cena do nascimento, é um sentimento gratificante, é o que mais me fascina no trabalho... (Luiza).

O estabelecimento de uma relação de confiança com os profissionais de saúde fortalece sentimentos positivos que tranquilizam as pacientes, pois sentem-se acolhidas e geram o sentimento de satisfação nas enfermeiras obstétricas (FRELLO; CARRARO et al., 2010).

Me sinto completa quando o trinômio está saudável e feliz. Dou o meu melhor e me sinto gratificada. Nesta hora é mais emoção do que razão... (Beatriz).

Trabalhar na maternidade significa pra mim gratidão, cuidar da geração de uma vida... (Ester).

Me sinto em um momento mágico, e pra mim é fundamental dar tudo certo na estadia dela na maternidade, é gratificante... (Carolina).

As enfermeiras obstétricas sentem-se responsáveis pelo cuidado prestado às parturientes. Isso está relacionado com o sentimento positivo pela saúde da paciente, uma vez 
que se preocupam com a eficácia das ações que exercem e com o bem-estar físico das clientes.

A enfermagem brasileira é originada da escola nightingaleana, o que conduz, nos dias atuais, à assistência administrativa e gerencial e, como líder da equipe de enfermagem, é responsável pela assistência prestada às parturientes, mesmo que divididas as responsabilidades com outros membros da equipe de saúde. Para fazer jus a esta incumbência, encarrega-se de controlar a assistência desenvolvida por todos (BERNI, 1994).

$\mathrm{Na}$ atuação da enfermeira obstétrica é oportuno afirmar que a responsabilidade é imprescindível para o exercício da profissão, uma vez que, além das funções gerenciais administrativas, presta-se atendimento humanizado nas diversas situações até a completa segurança do binômio.

Meu trabalho exige muita responsabilidade, é uma entrega muito grande, cada dia que passa sei que quanto mais carinho posso dar, melhor, é para a paciente, pois ela muitas vezes não recebeu do parceiro e da família, é um significado de gratidão, tudo fica melhor com carinho... (Lia).

Acho o trabalho como um todo de uma responsabilidade enorme, porque um deslize e tudo que estava certo fica incerto... (Renata).

Eu gosto de trabalhar na maternidade, de fazer partos, de assistir a parturiente, me sinto responsável, satisfeita e com gratidão... (Gisele). 
O trabalho prestado pelas enfermeiras nas maternidades é marcado pela dedicação, admiração e gratidão, e é muitas vezes movido pela responsabilidade que sentem pela saúde das parturientes e pelo bom funcionamento das unidades onde atuam.

O meu sentimento é de admiração e gratidão, é lindo ver esta obra divina, dois corações batendo no mesmo corpo e ver a dádiva de gerar uma vida... (Stela).

O meu trabalho é inspirador, gratificante, divino... (Rose).

Trabalhar na atenção materna, nos cuidados com o nascimento, é sinônimo de amor, sinto gratidão... (Bruna).

O que mais gosto é ver a gratidão no final, já teve casos em que a mãe chega em você e te agradece por tudo naquele momento (...), ver que servimos para alguma coisa, é muito gratificante... (Carla).

A despeito dos interesses econômicos privilegiarem cada vez mais o estudo da razão em detrimento do estudo das emoções, não obstante o avanço tecnológico, o ser humano continua dotado essencialmente de sentimentos e emoções, que, por sua vez, constituem a subjetividade de cada ser.

De acordo com Bock et al. (2008), devemos entender os seres humanos para além da vida cognitiva e racional, considerando-se que a vida afetiva é parte integrante da subjetividade humana. Para a autora "subjetividade é a síntese singular e individual que cada um de nós vai constituindo conforme vamos nos desenvolvendo e vivenciando as experiências da vida social e cultural".

O sentido da cultura se dá nas ações, nos pensamentos, nos ritos e na vida das pessoas, partindo do pressuposto de que para isso deve-se ultrapassar, ir além da simples 
descrição da cultura, porquanto entende o autor que é na interpretação que nos aproximamos do entendimento do objeto pesquisado, isto é:

Acreditando, como Max Weber, que o homem é um animal amarrado a teias de significados que ele mesmo teceu, assumo a cultura como sendo essas teias e a sua análise, portanto, não como uma ciência experimental em busca de leis, mas como uma ciência interpretativa, à procura do significado. É justamente uma explicação que eu procuro, ao construir expressões sociais enigmáticas na sua superfície (GEERTZ, 2014).

Tomando essa citação como uma provação, ao interpretar as teias tecidas pelas enfermeiras obstétricas, depara-se com os sentimentos presentes de forma explicita ou velada na vivência delas no cenário da atenção ao parto e na inserção nos serviços de atenção materna.

Elas, em suas práticas na enfermagem, imprimem a subjetividade, ou seja, trazem os afetos por meio de reações emocionais que revelam vivências ou estados emocionais. Emoções e sentimentos, alimentos do psiquismo humano, fazem parte integrante da constituição da subjetividade das enfermeiras e estão presentes em todas as manifestações da vida humana, entre outras, no hospital. Os sentimentos dão cor e sabor às atividades da vida diária e influenciam positivamente ou negativamente nas tomadas de decisão em situações de trabalho. Estados emocionais fazem parte diuturnamente do profissional de enfermagem; o ato de cuidar do outro torna-o uma pessoa mais vulnerável ao sofrimento alheio, pois, no exercício do oficio, dispensa cuidado, atenção, respeito, medo e reações psíquicas diversas, de cujas dimensões às vezes nem ele mesmo tem consciência.

“As reações orgânicas fogem ao nosso controle. Podemos 'segurar o choro', mas não conseguimos deixar de 'chorar por dentro'. Às vezes até tentamos, mas não 
conseguimos segurar duas ou três lágrimas que escorrem, traindo-nos e demonstrando nossa emoção" (BOCK et al., 2008).

\subsection{Análise do Grupo Focal}

Nesta seção serão apresentados os resultados dos dados analisados e descritos, tendo duas categorias temáticas como aporte: 1 . Fatores facilitadores da assistência em enfermagem obstétrica: potencialidades emanadas nos cenários da admissão, pré-parto, parto e pós-parto imediato, e 2. Fatores dificultadores da assistência da enfermeira obstétrica: fragilidades afloradas nos cenários de admissão, pré-parto, parto e pós-parto imediato. Desta forma, visamos responder aos objetivos propostos nesta pesquisa.

Participaram da etapa do grupo focal as enfermeiras obstétricas: Gabriela, Clara, Beatriz, Maria, Rose, Luiza, Lia, Denise, Carolina e Cleo.

\subsubsection{Fatores facilitadores na assistência da enfermeira obstétrica: potencialidades emanadas nos cenários da admissão, pré-parto, parto e pós-parto imediato}

As enfermeiras obstétricas elencaram o planejamento familiar como um fator potencializador da assistência à mulher, visto que, quando estabelecido, possibilita o entendimento de todo o curso da gestação, desde a concepção até o momento do parto e puerpério.

A atuação dos profissionais de saúde, no que tange ao Planejamento Familiar, está sustentada no Artigo 226, Parágrafo 7, da Constituição da República Federativa 
do Brasil, portanto, no princípio da paternidade responsável e no direito de livre escolha dos indivíduos e/ou casais (BRASIL, 2002a).

$\mathrm{Na}$ atualidade temos dificuldade em definir o conceito de família pela diversidade de modelos encontrados na sociedade, porém podemos entendê-la como um grupo social que desempenha funções sexuais, procriativas, econômicas e educativas. Desta forma, ter filhos é exercer a função procriativa; é necessário fazer um planejamento para a instituição da família e a agregação dela na sociedade (SANCHES; SIMÂO-SILVA, 2016).

Neste sentido, o planejamento da família é um método de intervenção e prevenção da família, devendo ser considerada não somente pela opinião da mulher mas da unidade familiar. Deve ser levada em consideração a fase do ciclo de vida da família, suas crenças, sua cultura, seus valores e suas tradições. Logo, o planejamento familiar dever ser pensado em etapas, passo a passo. O planejamento de uma gravidez é o momento em que a mulher assume o papel principal, pois a gestação é uma condição humana que somente ela pode vivenciar.

O planejamento familiar, quando estabelecido, foi destacado pelas enfermeiras obstétricas como um fator potencializador na assistência da enfermeira obstétrica, realçada nas falas e nas fotografias produzidas por elas.

Para garantir o exercício pleno dos direitos reprodutivos se faz necessária a ampliação do acesso de mulheres e homens à informação acerca dos métodos contraceptivos. É necessário ter a oferta de métodos anticoncepcionais em toda rede pública de saúde e ter profissionais capacitados para auxiliar a mulher na melhor escolha contraceptiva, dependendo do momento de vida (BRASIL, 2002a). Essa afirmação veio ao encontro das Figuras 1 e 2, em que é possível visualizar elementos que uma das enfermeiras selecionou como de 
fundamental importância no âmbito do conhecimento para aqueles que pretendem ter planejamento familiar.

O planejamento familiar deveria facilitar, se as pessoas o praticassem, se por exemplo já viessem para a maternidade com plena consciência da gravidez $e$ expectativas. Nas UBS as pacientes não têm orientações sobre métodos anticoncepcionais, eles já vão colocando empecilho e orientando laqueadura...... (Gabriela).

O planejamento familiar é a parte principal do nosso trabalho... (Carla).

Muitas vezes elas não têm acesso aos métodos anticoncepcionais... (Maria).

Entender a gravidez independentemente da idade, ela tem que saber o que será feito a partir desse momento, ter uma autonomia dessa gestação, escolher os métodos contraceptivos... (Beatriz).

Um outro empecilho é ela conseguir o método quando é menor de idade, tem que ter o consentimento dos pais... (Rose).

O uso de métodos contraceptivos está relacionado com a cultura da usuária, porque os valores sociais estão presentes na tomada de decisão sobre qual a melhor escolha, que está condicionada à cultura religiosa, antecedentes familiares e conhecimento científicos sobre os benefícios/malefícios do uso de método de contracepção. Isto demonstra que é necessário conhecer o meio social em que o indivíduo vive para compreender suas escolhas.

É importante salientar que uma das atribuições da enfermeira obstétrica é atuar no manejo do planejamento familiar com ações que envolvam atividades educativas (Figura 2), de aconselhamento e atividades clínicas. Essas práticas devem ser desenvolvidas 
de forma integrada, abordando a saúde e o bem-estar em geral, não somente a contracepção. Essas ações por parte da enfermeira obstétrica estão diretamente ligadas à cultura da população, o sucesso ou fracasso na atuação de conscientização em relação ao planejamento familiar e dependem diretamente da perspectiva de cultura de cada indivíduo. Logo, o pensamento humano é social, na forma e na aplicação (GEERTZ, 2001; GEERTZ, 2014).

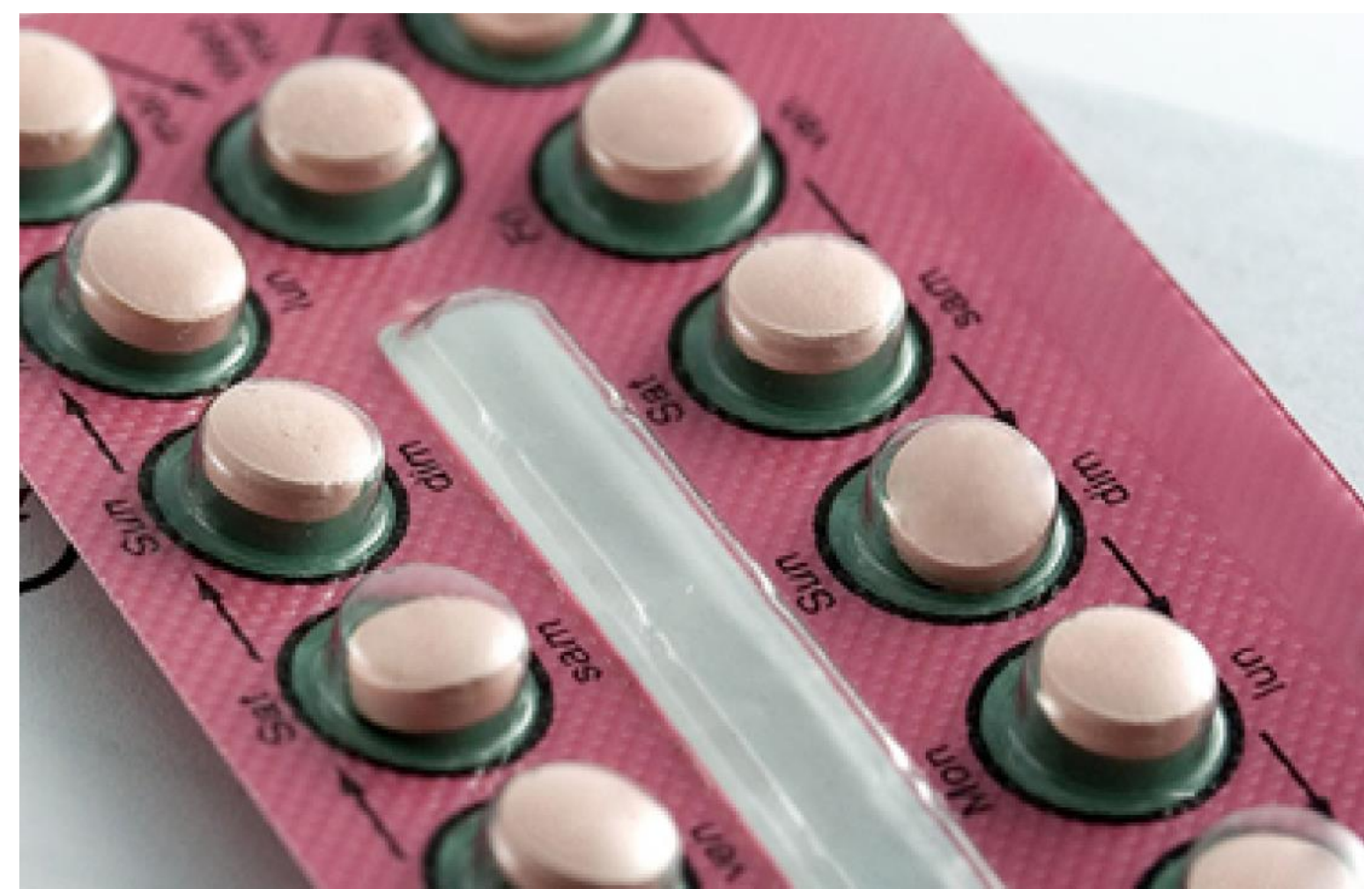

Figura 1 - Fotografia selecionada pela Enfermeira Obstétrica Beatriz ${ }^{1}$

Em detrimento do movimento de institucionalização do parto, a mulher ficou passiva na escolha do parto e restou a ela a hospitalização para receber assistência profissional em saúde durante seu processo de parturição. Esse processo gera estresse, pois

1 Imagem disponível em <http://www.dietaja.org/wp-content/uploads/2015/07/metodoscontraceptivos.png >. Acesso durante o período de coleta de dados. 
além de ficar separada de sua família e do universo domiciliar, o cenário encontrado pela mulher é de normas e rotinas hospitalares, com regras que muitas vezes não preservam a humanização na assistência (SOUZA et al., 2010).

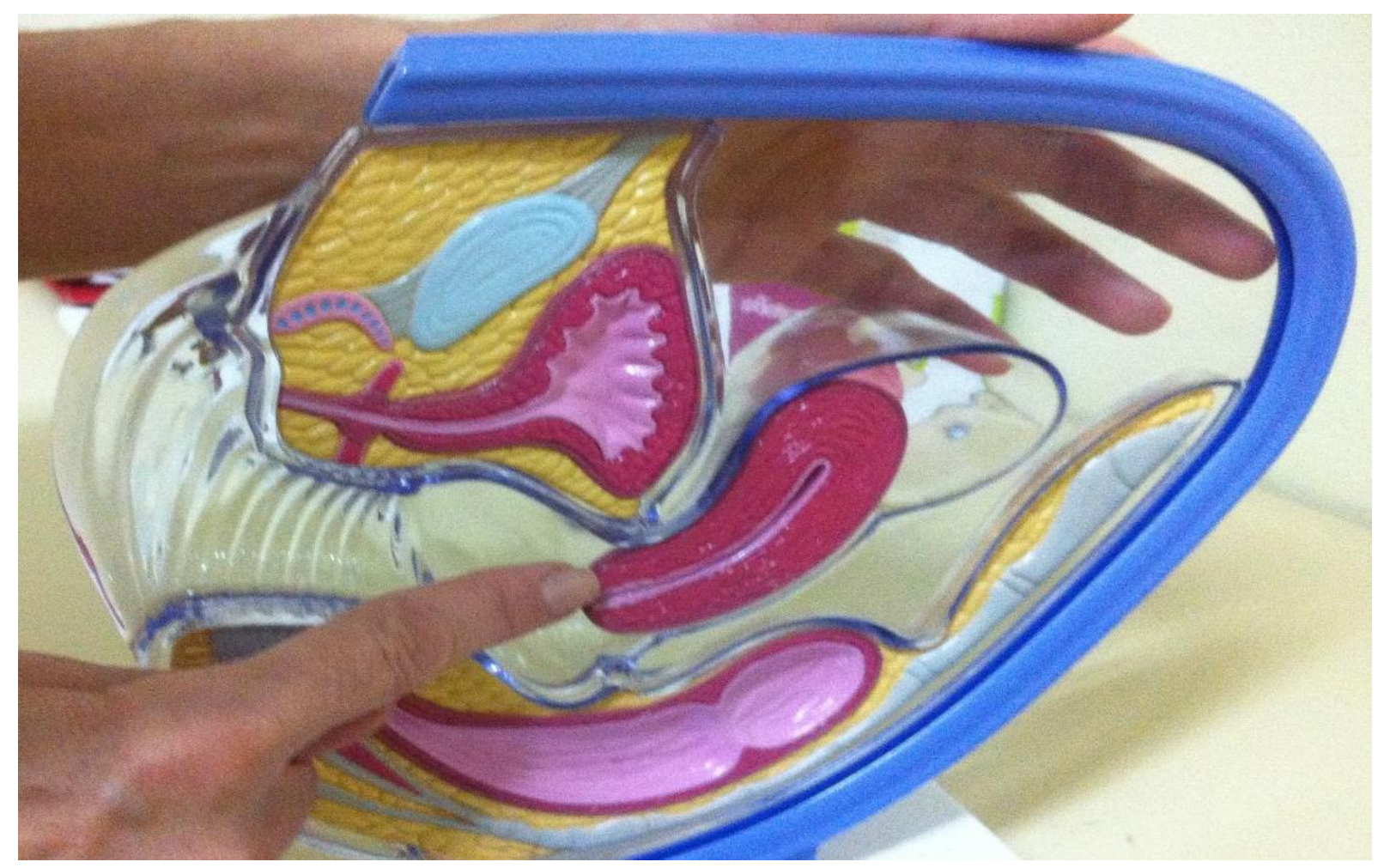

Figura 2 - Fotografia produzida pela Enfermeira Obstétrica Cleo

Neste âmbito, o cuidado prestado à parturiente e sua família deve ser concentrado na individualidade, dado que o ser humano é diferenciado na própria natureza e apresenta culturalmente características específicas, que devem ser respeitadas e valorizadas, minimizando os procedimentos e normas já estabelecidas previamente (MACHADO; PRAÇA, 2006).

Desta forma, o modo de atuar da enfermeira obstétrica é de grande importância no cuidado à parturiente, dada a cultura de sua assistência e do local onde 
trabalha, uma vez que adotadas medidas que visam aliviar a dor, favorecer o nascimento de forma natural e serem menos intervencionistas. Isso se traduz em uma abordagem empática, visando a um processo de parturição mais ameno e menos doloroso, uma vez que as parturientes precisam de acolhimento e atenção (CLUETT; BURNS, 2009; DAVIM et al., 2008).

A Figura 3 retrata a temática da humanização da assistência ao parto, lembrando que essas ações dependem diretamente das diferentes culturas presentes nas maternidades, uma vez que necessitam da organização do cuidado centralizado nas necessidades das mulheres e seus familiares, das adequações na estrutura física das unidades de atendimento e ambientes. Há a necessidade de um local aconchegante, propício para a prática de assistência humanizada, em que há respeito pela fisiologia do trabalho de parto, pela autonomia da parturiente, pela presença do acompanhante, com intervenções realmente necessárias e com a devida comunicação e consentimento prévio das ações e atitudes que serão tomadas (CARRARO et al., 2013; DIAS; DOMINGUES, 2005).

O conceito de parto humanizado é amplo e variado, mas há consenso em afirmar que a expressão pode ser utilizada para os partos em que a mulher é respeitada nas suas preferências, tem como escolha o acompanhante que desejar, possui liberdade de movimentação, ingere líquidos e alimentos leves à vontade e escolhe a posição para o nascimento. Desta forma, são evitados procedimentos intervencionistas e com pouca ou nenhuma evidência científica, como, por exemplo, o uso rotineiro de ocitocina, lavagem intestinal, tricotomia pubiana total, episiotomia e jejum (BRASIL, 2001; CONSELHO FEDERAL DE ENFERMAGEM, 2016). 


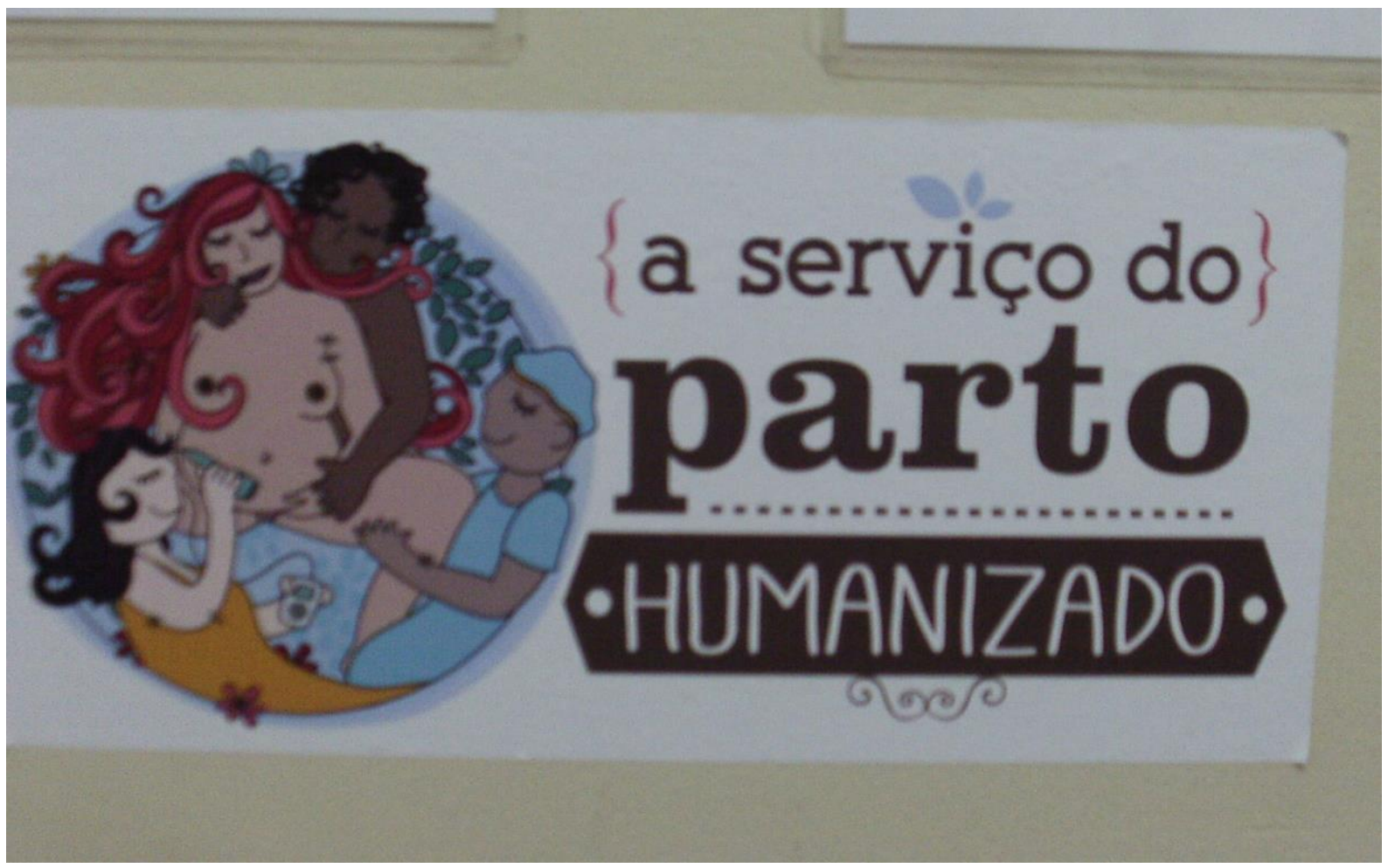

Figura 3 - Fotografia produzida pela Enfermeira Obstétrica Beatriz

Embora o cuidado humanizado devesse ser um procedimento natural e rotineiro, observa-se que, na realidade, ele não é prática que vem acontecendo nas maternidades, devido à institucionalização da assistência, ao aumento no número de intervenções e procedimentos cirúrgicos, na maioria das vezes desnecessários e definidas previamente pelo meio social como o melhor método para evitar sofrimentos.

Durante o grupo focal, as enfermeiras obstétricas foram unânimes ao relatarem e discutirem que, ao prestarem uma assistência obstétrica humanizada, favorecem o acolhimento, a satisfação e o bem-estar do binômio mãe e filho, o que pode ser observado nos relatos descritos abaixo.

A humanização na assistência ao parto facilita a evolução do parto, quando utiliza o PPP, o bebê fica no mesmo espaço da mãe... (Gabriela). 
A humanização facilita muito, porque antes elas só ficavam deitadas na cama em trabalho de parto, sem acompanhante, então estas medidas ajudam a evolução $e$ satisfação delas... (Maria).

Antigamente nem o pai ficava na sala, vivemos em um tempo onde praticar a humanização gera muitos benefícios para a mãe e bebê... (Lia).

A humanização do parto e nascimento tem como objetivo romper com o modelo intervencionista, de forma a valorizar a autonomia da mulher, tendo em vista a adoção de práticas comprovadamente benéficas no momento de parturição (FUJITA; SHIMO, 2014).

O MS e a OMS têm constantemente dado suporte a práticas de assistência ao parto qualificada, humanizada e segura (BRASIL, 2013b).

A utilização de métodos não farmacológicos para o alívio da dor no trabalho de parto é uma prática que visa melhorar a satisfação da parturiente, diminuir a ansiedade e favorecer o encaminhamento natural do processo de parturição. É uma prática classificada pela OMS como "condutas que são claramente úteis e que deveriam ser encorajadas"; condutas implementadas como forma humanizada de atendimento no manejo da dor no trabalho de parto (MAFETONI; SHINO, 2015).

A dor no trabalho de parto é sinalizada pelas mulheres nas diferentes formas e é influenciada por diversos fatores culturais, familiares, de ansiedade, medo, experiência anterior e faixa social a que pertencem. Visitando Geertz (2014), podemos entender que a 
intensidade da dor no trabalho de parto e parto depende da natureza das atividades sociais e das relações entre elas. Vários profissionais adotam em sua prática assistencial no pré-parto o uso da bola suíça, estímulo ao banho de aspersão ou imersão em água morna, deambulação e uso de banquinhos para favorecer a descida fetal (BARBIERI et al., 2013).

A bola suíça, mostrada na Figura 4 a seguir, é um objeto que pode ser utilizado como mecanismo para auxiliar na estratégia de diminuição da dor e favorecimento da evolução do trabalho de parto. Estudos mostram que, quando utilizada na fase ativa do trabalho de parto, é extremamente eficaz na abreviação do período clínico de dilatação, embora ainda faltem estudos para fundamentar a sua utilização, sendo utilizada na atualidade de forma empírica (SILVA et al., 2011).

A utilização de métodos como bola suíça, o banquinho em forma de $\mathrm{U}$ e prática de deambulação dependerá tanto do conhecimento adquirido pela enfermeira obstétrica como da usuária e o valor que é atribuído a esta prática. Sendo assim, o uso de métodos não farmacológicos para a condução do trabalho de parto está condicionado à cultura da organização, dos profissionais de saúde e dos usuários.

As fotos produzidas refletiram positivamente ações, equipamentos e manejos utilizados no controle não farmacológico da dor no trabalho de parto e os discursos corroboraram a afirmação de que a humanização no ambiente do nascimento favorece o bemestar materno e fetal e a assistência da enfermeira obstétrica.

O parto e nascimento são acontecimentos fundamentais na vida humana. A forma como enfrentamos esse evento reflete os valores da sociedade e da nossa cultura, os quais são determinantes para a assistência ao parto e os legitimam. 


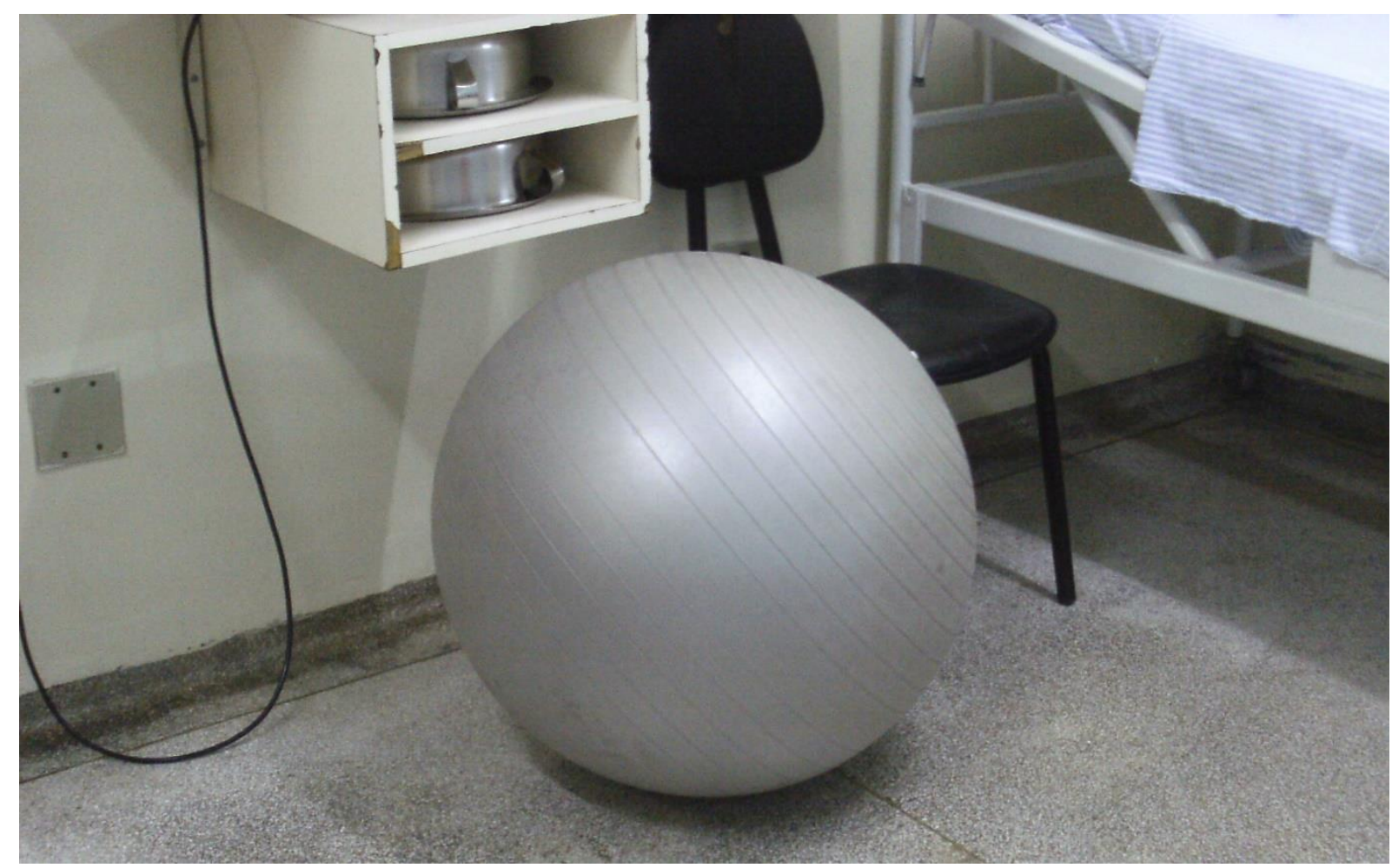

Figura 4 - Fotografia produzida pela Enfermeira Obstétrica Maria

Não são todos profissionais que estão aptos a realizarem o procedimento do uso do banquinho e bola, nem todas gestantes também conhecem essa disponibilidade, é nosso dever estar utilizando de medidas que facilitem o trabalho de parto, para minimizar a dor no momento do nascimento... (Gabriela).

Eu entendo que a humanização seja um fator facilitador pra nós enfermeiros pois é onde podemos atuar, um modelo não intervencionista, gosto de usar métodos que não são farmacológicos... (Beatriz).

O uso da bola e banquinho fizeram uma diferença positiva pois a mãe fica mais calma tendo a presença do acompanhante e recebendo as orientações necessárias... (Clara) 
Esses dias mesmo ouvi um elogio de uma paciente pois mãe e família ficam muito mais calmas, pois adotamos medidas para conforto, práticas de humanização, antigamente chegavam pedindo cesariana, logo de cara... (Maria).

As habilidades práticas das enfermeiras obstétricas e o desempenho em ações voltadas para humanização permitem identificar e corrigir precocemente qualquer intercorrência no mecanismo fisiológico da gestação, proporcionando melhor qualidade na assistência ao parto e nascimento (BARROS; SILVA, 2004).

A relação efetiva entre a mulher e os profissionais de saúde durante todo processo de parturição contribui para aliviar a ansiedade, superar as dúvidas e temores. O ambiente deve estar culturalmente preparado para que esta prática ocorra de forma humanizada, devendo ser acolhedor e aconchegante (CHECHIN, 2002).

A Rede Cegonha, instituída no âmbito do SUS pela da Portaria n ${ }^{\circ} 1459$ de 24 de junho de 2011, no Art.7 prevê a ambiência das maternidades, favorecendo o acesso sem discriminação, minimizando e eliminando barreiras físicas naturais ou arquitetônicas, com medidas que garantam a acessibilidade, mobilidade, ergonomia, conforto térmico, acústico e iluminação. A Figura 5 ilustra a imagem de um leito PPP (pré-parto, parto e puerpério) muito utilizado na ambiência das maternidades no modelo humanizado (BRASIL, 2011a; BRASIL, 2014a).

Algumas práticas assistenciais são destacadas como facilitadoras da evolução do trabalho de parto, diminuindo as intervenções e procedimentos desnecessários e maléficos para o nascimento. Neste sentido, vale ressaltar a prática do banho de imersão ou 
aspersão e uso do banquinho como ações positivas, adotadas em algumas instituições participantes deste estudo, destacadas em fotografias e relatos das enfermeiras obstétricas.

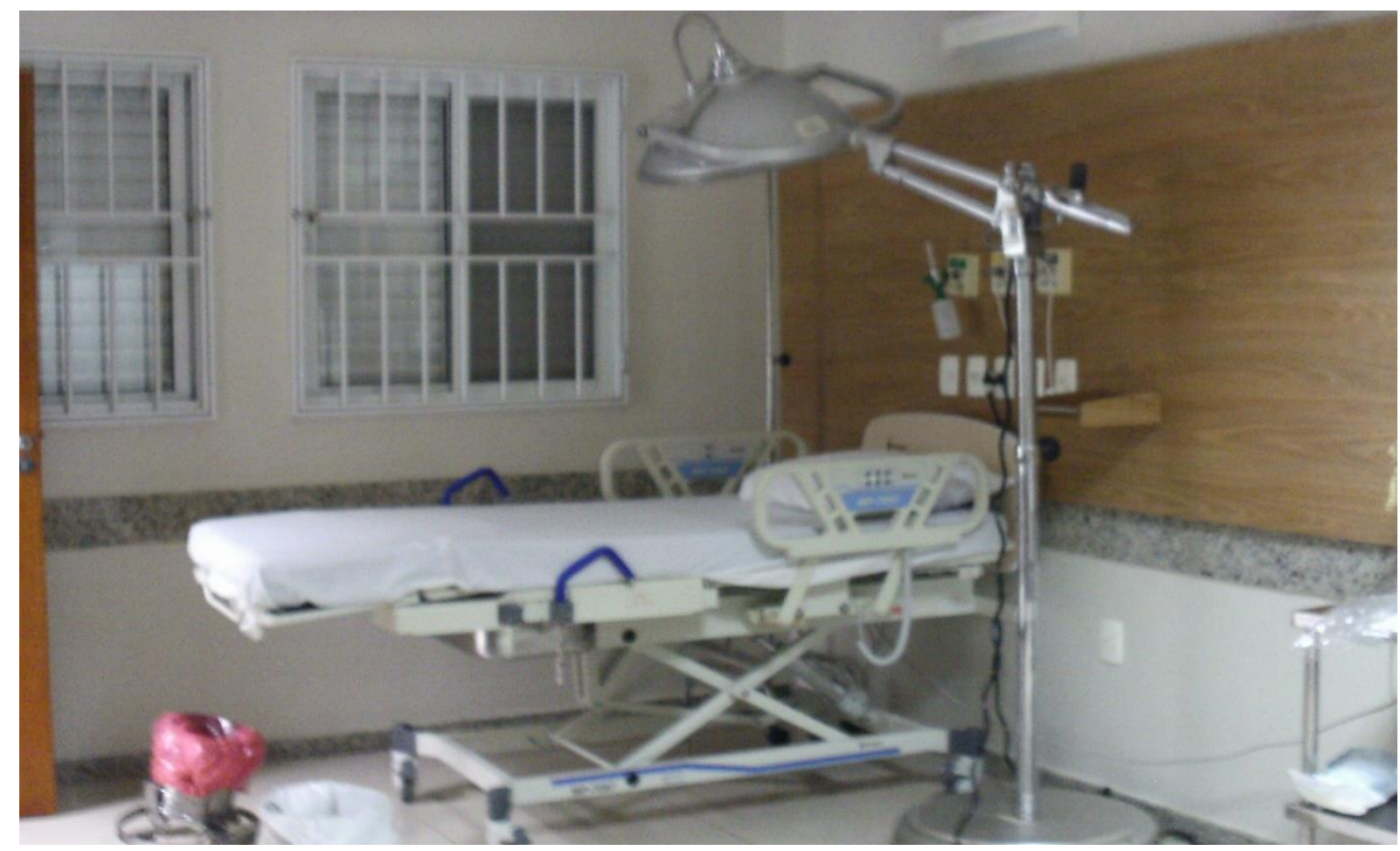

Figura 5 - Fotografia produzida pela Enfermeira Obstétrica Carolina

Há evidências científicas de que a imersão em água durante o primeiro período do trabalho de parto reduz de forma significativa a necessidade de analgesia, sem afetar negativamente a duração do trabalho de parto, a taxa de parto cirúrgico e o bem-estar neonatal. É necessário ressaltar que, além dos benefícios na condução e evolução do parto, também devemos levar em consideração os dados que informam a elevação da satisfação das pacientes em relação ao parto quando adotadas estas práticas (SANTANA et al., 2013; DAVIM et al., 2008). 
O uso de água aquecida no trabalho de parto tem o objetivo de promover a vasodilatação e a redistribuição sanguínea, proporcionando o relaxamento muscular. Há a liberação de catecolaminas e síntese elevada de endorfinas, resultando em diminuição da ansiedade e aumentando a satisfação da paciente. A utilização do banquinho visa ao relaxamento, o aumento natural da dilatação e a diminuição da dor (GALLO et al., 2011).

A Figura 6 abaixo sinaliza o uso da banheira nos cuidados à parturiente no pré-parto.

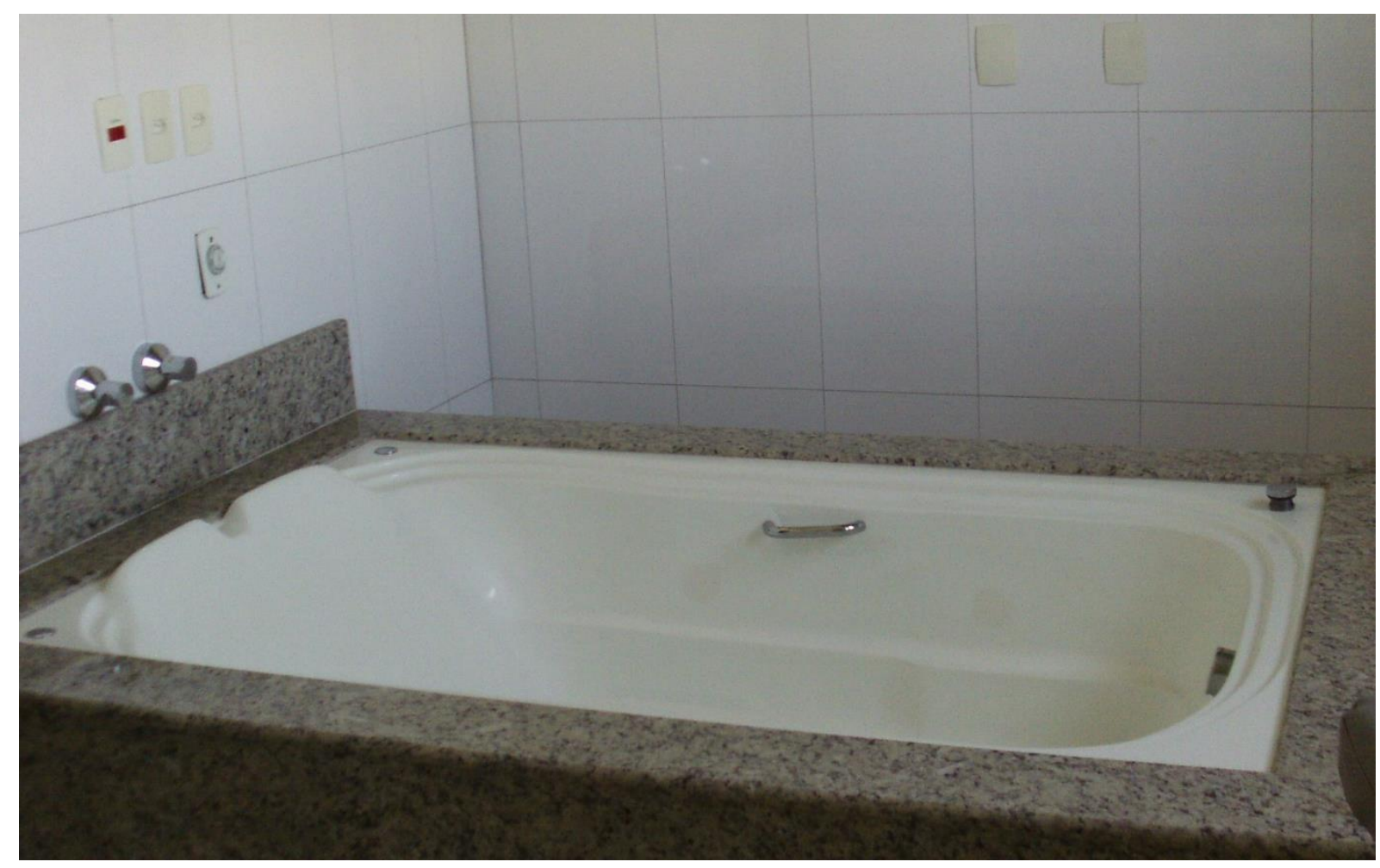

Figura 6 - Fotografia produzida pela Enfermeira Obstétrica Eva

A banheira existe há uns três anos mas ninguém usava no hospital onde trabalho. Há três meses houve a liberação para o uso da banheira na sala de parto, que pode ser utilizada tanto no particular assim como pelo SUS; com esta liberação, conseguimos humanizar a assistência prestada... (Denise). 
Antes era um quarto que só as enfermeiras que possuíam a técnica usavam, mas agora a sala de parto foi feita no mesmo espaço da banheira e liberada a utilização para todos em trabalho de parto, depende também da condição do plantão; de qualquer forma com a banheira na sala de parto não precisamos locomover a gestante do quarto para sala de parto, o atendimento é humanizado... (Maria).

A utilização do banquinho em forma de $U$ facilita a assistência não farmacológica ao parto e melhora a evolução do trabalho de parto... (Beatriz).

Depende muito da enfermeira que está ajudando, pois a banheira é um "elefante branco" para alguns profissionais, eи a utilizo porque acredito que relaxa a mulher e diminui a dor... (Gabriela)

Ao utilizarmos recursos não farmacológicos para alívio da dor no trabalho de parto e parto, busca-se promover uma assistência obstétrica humanizada de forma ampliada. Devemos promover a autonomia da mulher, pois sua participação se torna ativa, ocasionando poucas intervenções e efeitos colaterais indesejáveis (SIMKIN; BOLDING, 2004; BRASIL, 2001; HODNETT et al., 2013; CAMPBELL et al., 2006).

No Brasil, métodos não farmacológicos para alívio da dor, como banheiras, bancos em forma de $\mathrm{U}$, cavalinhos e aparelhos de massagem, ainda são pouco utilizados, 
devido à ausência dessas estruturas e materiais nas instituições, apesar de ampla literatura científica publicada evidenciando seus efeitos positivos no alívio da dor e na progressão do trabalho de parto (CLUETT; BURNS, 2009; DAVIM et al., 2008; MALAREWICZ, 2005; GALLO et al., 2011).

A enfermeira obstétrica Rose destacou, na Figura 7 (abaixo), o banquinho em forma de U como um fator facilitador na sua atuação profissional, como maneira de atuar humanizando a assistência à mulher no trabalho de parto e parto.

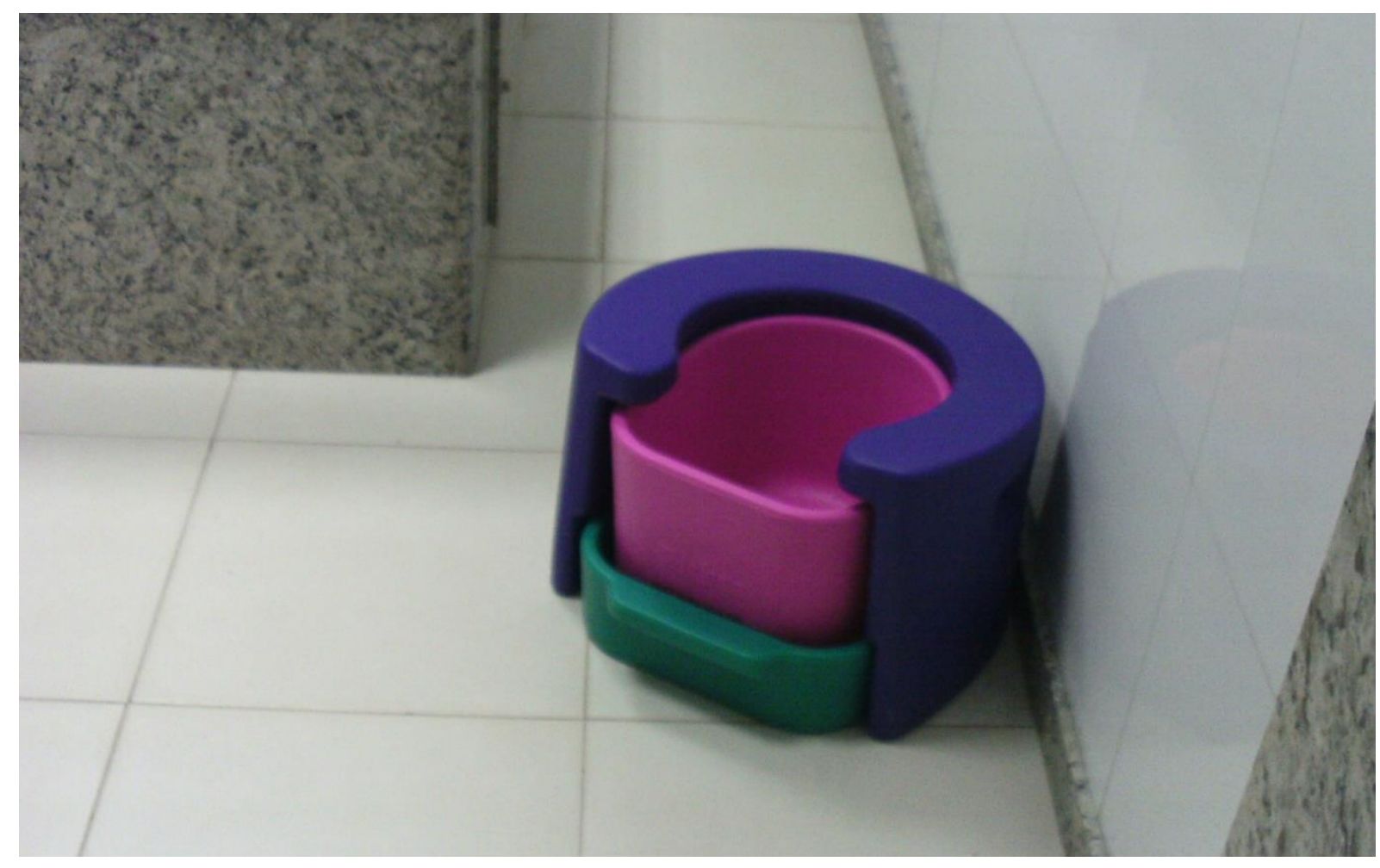

Figura 7 - Fotografia produzida pela Enfermeira Obstétrica Rose

Em nosso país, o MS premiou algumas instituições que realizam ações de humanização na assistência ao parto e nascimento. O Prêmio Galba de Araújo foi criado em 1999 com o objetivo de reconhecer as instituições de saúde integradas à rede SUS que 
desenvolvem e se destacam na humanização à mulher e ao recém-nascido, estimulam o parto normal e aleitamento materno. A Figura 8 apresenta o cartaz contemplativo do prêmio destinado as instituições elegíveis.

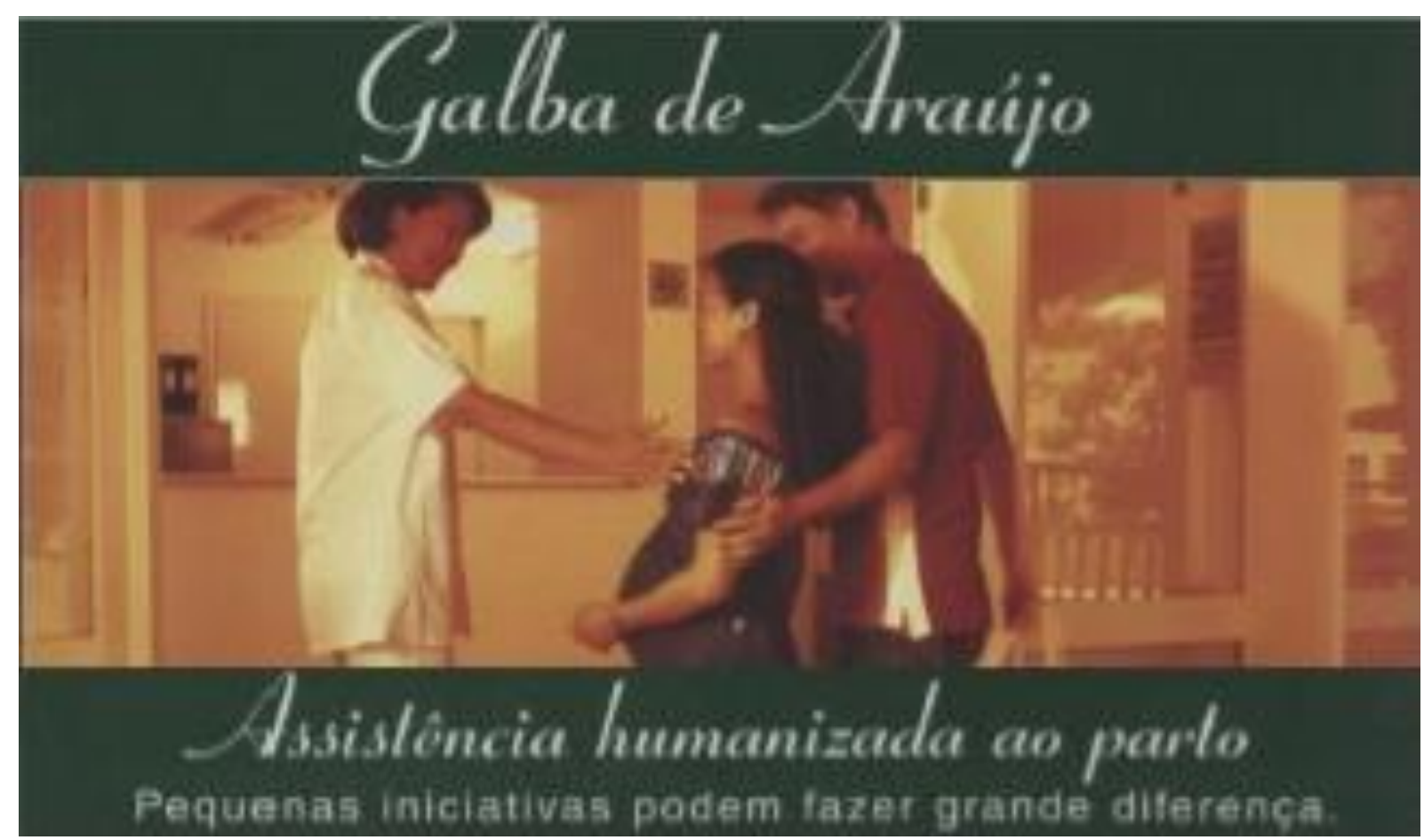

Figura 8 - Fotografia selecionada pela Enfermeira Obstétrica Beatriz ${ }^{2}$

Para receber esta premiação, foram estabelecidos 10 passos que devem ser seguidos para garantir a humanização no parto e os direitos da mulher, a saber (BRASIL, 1999b):

1 - Presença do companheiro ou alguém da família para acompanhar o parto, dando segurança e apoio;

2 - Receber orientações, passo a passo, sobre o parto e os procedimentos que serão adotados com a mulher e bebê. A mulher bem informada faz melhor a sua parte, ajuda mais;

\footnotetext{
${ }^{2}$ Disponível em < http://bvsms.saude.gov.br/bvs/>. Acesso durante o período de coleta de dados.
} 
3 - Receber líquidos (água, suco), pois o trabalho de parto pode durar até 12 horas;

4 - Liberdade de movimentos durante o trabalho de parto. A mulher pode caminhar sem restrições;

5 - Escolha da posição mais confortável para o parto;

6 - Relaxamento para aliviar a dor. Pode ser massagem, banho morno ou qualquer forma de relaxamento conveniente para a mulher;

7 - Parto seguro, sem muitos procedimentos que podem atrapalhar em vez de ajudar. É importante verificar sempre as contrações e auscultar o coração do bebê;

8 - Contato imediato com o bebê logo que nasce. Muito importante para mãe e filho;

9 - Alojamento conjunto, para que o bebê fique o tempo todo perto da mãe, recebendo seu carinho e atenção;

10 - Respeito. A mulher deve ser respeitada, chamada pelo nome, ter privacidade, ser atendida em suas necessidades.

Foi possível constatar nos relatos das enfermeiras obstétricas a importância desse tipo de premiação para a valorização da profissão perante as usuárias e seus familiares, fazendo com que as instituições estejam sempre aptas à prática da humanização ao parto e nascimento. A Figura 9, traz a estátua recebida na premiação da instituição Estrela, que em 2006 recebeu o Prêmio Galba de Araújo. 


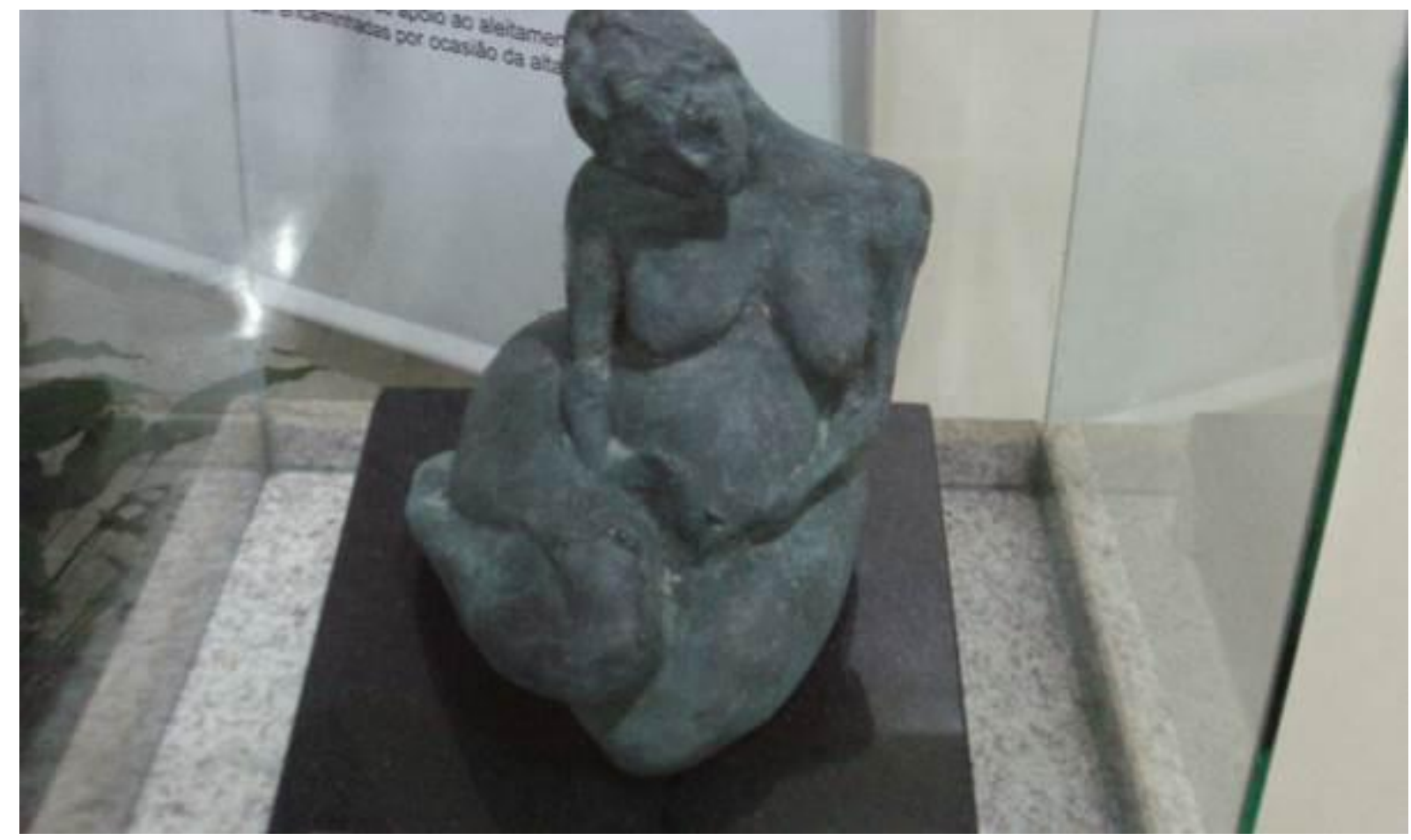

Figura 9 - Fotografia produzida pela Enfermeira Obstétrica Beatriz

Através de placas de certificação a vista onde trabalho, podemos mostrar ao público nosso trabalho de humanização do parto, valorizando a enfermagem obstétrica... (Maria).

Isso faz com que o hospital se estruture para receber o prêmio e dê continuidade ao trabalho, diferente de alguns que apenas se maquiam para receber o prêmio e depois não praticam mais os trabalhos. Valorizando assim a humanização do parto através da atenção com a criança e mulher... (Beatriz).

Hoje as políticas estão mudando muito, tanto que a maternidade onde eu trabalho está recebendo um incentivo maior, o hospital "amigo da criança" passa a 
ser hospital "amigo da criança e da mulher", temos um prazo para se adequar e quem não o fizer perde o título... (Joana).

Essas estratégias de premiação fazem com que o hospital mantenha o nível... (Clara).

Ao premiar as instituições pela qualidade da assistência obstétrica humanizada, o MS incentivou as organizações e os profissionais para instituírem na cultura local ações que aprimorassem o atendimento humanizado e fomentou recursos financeiros para melhoria na estrutura física das maternidades premiadas.

A Figura 10, traz a imagem de um aparelho de cardiotocografia, traduzido como uma ação de autonomia para a prática assistencial das enfermeiras obstétricas. Trata-se de um exame realizado durante o trabalho de parto para avaliação da vitalidade fetal. Sua prática é regida pelo Decreto $n^{\circ} 94.406$ de 1987, que regulamenta a Lei $n^{\circ} 7.498$ de 25 de Junho de 1986, que dispõe sobre a Lei do Exercício Profissional de Enfermagem e, mais recentemente, a Resolução $\mathrm{n}^{\circ} 478$ de 14 de abril de 2015, que normatiza a atuação e sua responsabilidade civil (BRASIL, 1986; 1987; CONSELHO FEDERAL DE ENFERMAGEM, 2015).

Agir com autonomia envolve ações e atitudes relacionados à personalidade do indivíduo. Embora não se ignore a concessão proporcionada pelo ambiente de trabalho, a oportunidade de atuar de forma coadjuvante é uma característica pessoal; logo, cada enfermeira age de forma individual e única. 
$\mathrm{Na}$ formação do enfermeiro, destaca-se o profissional com autonomia, integrando estudo e trabalho, com ampla visão para a educação e participação plena na sociedade, culturalmente ambientado para trabalhar em grupos, à medida que estimula o favorecimento de discussões coletivas e relacionamento interpessoal (BRASIL, 2001; 2002b; 2006).

A autonomia manifesta-se na atuação da enfermeira obstétrica em conjunto com o domínio do conhecimento da ciência; está para além da possibilidade e permissão, a autonomia envolve uma pulsão interna de vida, um desejo pulsante na busca da realização profissional, movida pelo querer fazer.

$\mathrm{Na}$ sala de diagnóstico, nós mesmos devemos tomar precauções cautelosas pois lá mesmo pode acontecer o parto ou outras situações de risco. O enfermeiro que é responsável por interpretar exames, para identificar os riscos, e se realizado da forma incorreta pode colocar a mãe e o bebê em risco, temos autonomia... (Carla).

$O$ uso de métodos naturais e não farmacológicos são fundamentais na assistência humanizada no parto $e$ nascimento... (Beatriz)

Realizamos o diagnostico inicial e muitas vezes informamos se a paciente deve voltar para a casa ou não, com muita responsabilidade pois colocamos a vida de ambos em segurança, temos que atuar com autonomia... (Denise). 


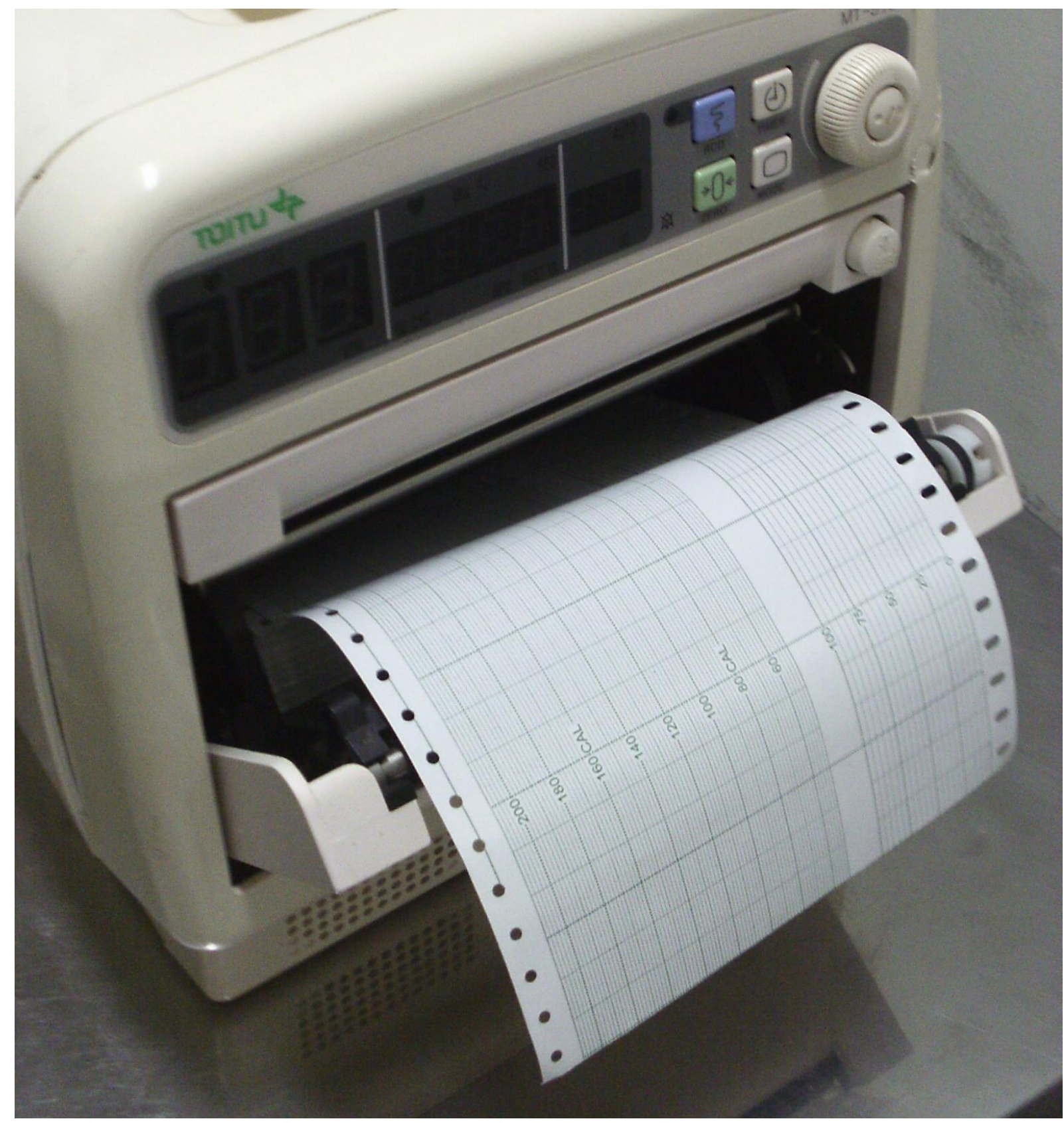

Figura 10 -Fotografia produzida pela Enfermeira Obstétrica Rose

No cenário da admissão, traduzida pela imagem da Figura 11, as enfermeiras obstétricas revelaram que o atendimento inicial gera autonomia e satisfação profissional, pois independente da cultura da instituição em que atuam, as ações realizadas 
pelas enfermeiras são de muita responsabilidade, porquanto atuam cuidando de duas vidas e devem garantir o bem-estar delas de forma eficaz e humanizada.

Neste sentido, devem garantir o atendimento individualizado, reconhecendo os valores culturais, crenças, necessidades e expectativas em relação ao parto e nascimento. Todos os procedimentos realizados devem estar acompanhados de uma explicação sobre o motivo de sua execução de forma a transmitir à mulher a real necessidade deles, contribuindo assim para o bem-estar materno e fetal (BRASIL, 2014a).

O Conselho Federal de Enfermagem (COFEN), na resolução n ${ }^{\circ} 516$ de 2016, normatiza a atuação e a responsabilidade da Enfermeira Obstétrica nas áreas de atuação, especialmente nos centros de parto normal e/ou casas de parto. Destacamos o Art. $3^{\circ}$, que traz como competência da enfermagem obstétrica a avaliação da evolução do trabalho de parto e as condições maternas e fetais, adotando tecnologias apropriadas na assistência e tomada de decisão, considerando a autonomia e protagonismo da mulher (CONSELHO FEDERAL DE ENFERMAGEM, 2016). 


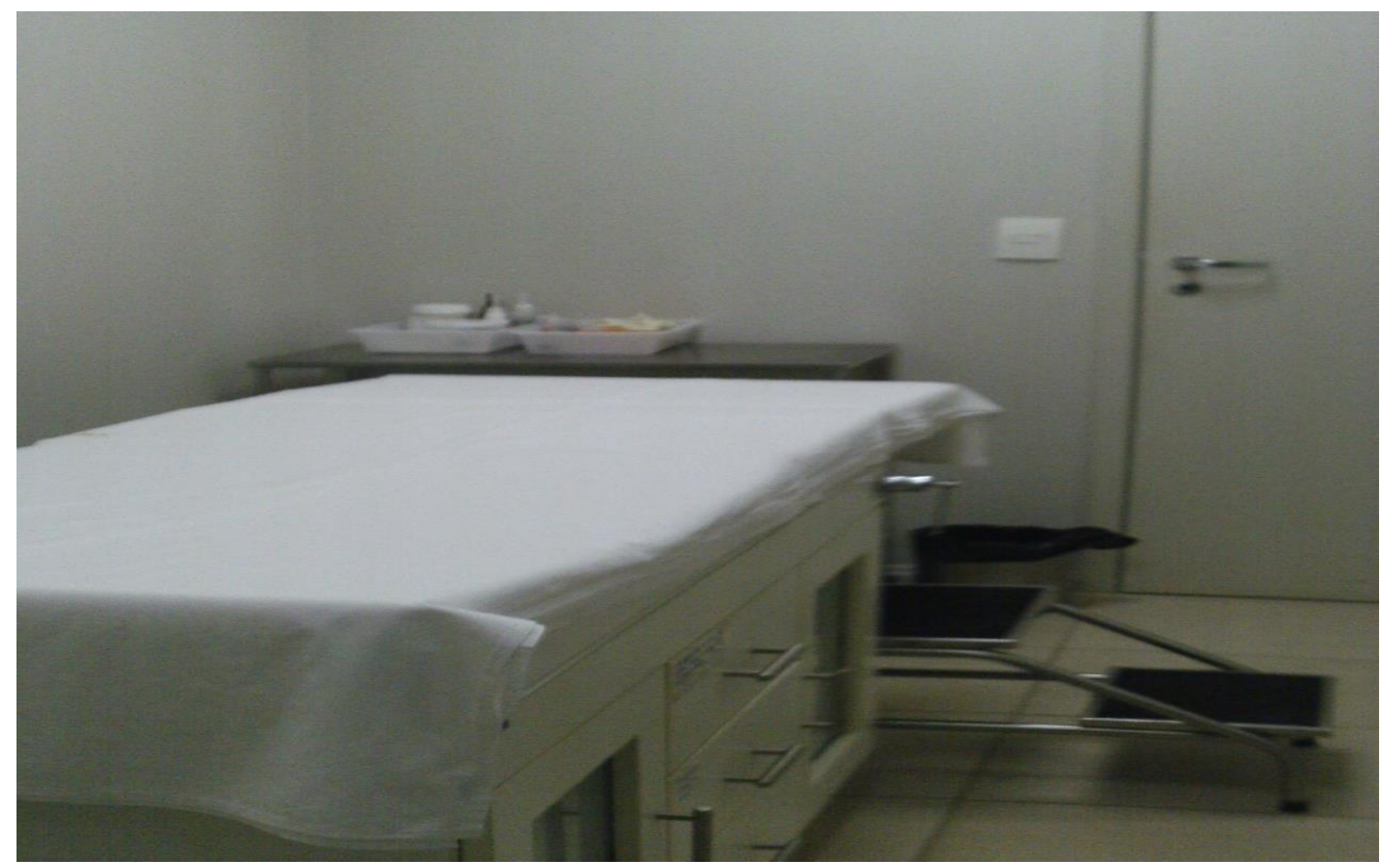

Figura 11 - Fotografia produzida pela Enfermeira Obstétrica Luiza

O ser humano já convivia coletivamente desde o nosso surgimento na Antiguidade, desenvolvendo ações de alta complexidade, impossíveis de serem realizadas sem a ajuda de um semelhante; desta forma, agrupavam-se com o objetivo de viverem em sociedade. Na atualidade, a utilização de grupos como estratégia na atenção a saúde é cada vez mais explorada nas propostas de educação do Ministério da Educação (PICHONRIVIERE, 2011).

Nas equipes de saúde, especificamente na enfermagem obstétrica, o trabalho em equipe significa associar o planejamento e a divisão de tarefas, apoio, colaboração e interação com os demais membros da equipe, suas práticas, culturas e necessidades (BASILE FILHO, 2011). 
Para Navarro et al (2013), o trabalho em equipe é traduzido nas relações estabelecidas dos membros entre si e no meio em que vivem pela sua cultura, sua prática, sua forma de atuar, agir, pensar e sentir. Desta forma, o que somos e representamos é exatamente o reflexo direto e fidedigno de nossas ações, o que é traduzido nas relações estabelecidas em equipes e grupos.

A Figura 12 vem demonstrar a forma e a necessidade do trabalho em equipe na prática da enfermagem. Quando os membros estão integrados, há crescimento de todos da equipe, pois cada um contribui com seus conhecimentos e habilidades e adquire outros que não possuía.

Neste sentido, as enfermeiras obstétricas destacaram nas discussões em grupo e nas fotografias, que, quando conseguem trabalhar em equipe, apresentam um melhor desempenho nas suas atividades e desvelaram potencialidades quando culturalmente estão inseridas nas equipes nas maternidades onde atuam.

Com o grupo de parto tomamos todas as decisões juntos, me sinto muito mal de trabalhar sem minha equipe, pois às vezes realizamos todos os procedimentos e o médico chega mudando tudo, esse grupo é composto por 2 obstetras e 3 enfermeiras obstétricas e mais uma doula, as decisões são tomadas a partir da concessão de todos do grupo. Atualmente acho imprescindivel a presença da “doula” para o auxílio psicológico, e o nosso para as decisões técnicas... (Gabriela).

Trabalhar em equipe faz toda diferença, agrega muito na minha atuação... (Beatriz) 
A minha realidade é trabalhar em equipe com o obstetra $e$ pediatra. Não há como atuar sem esta sinergia, a paciente sempre vai sair beneficiada... (Rose).

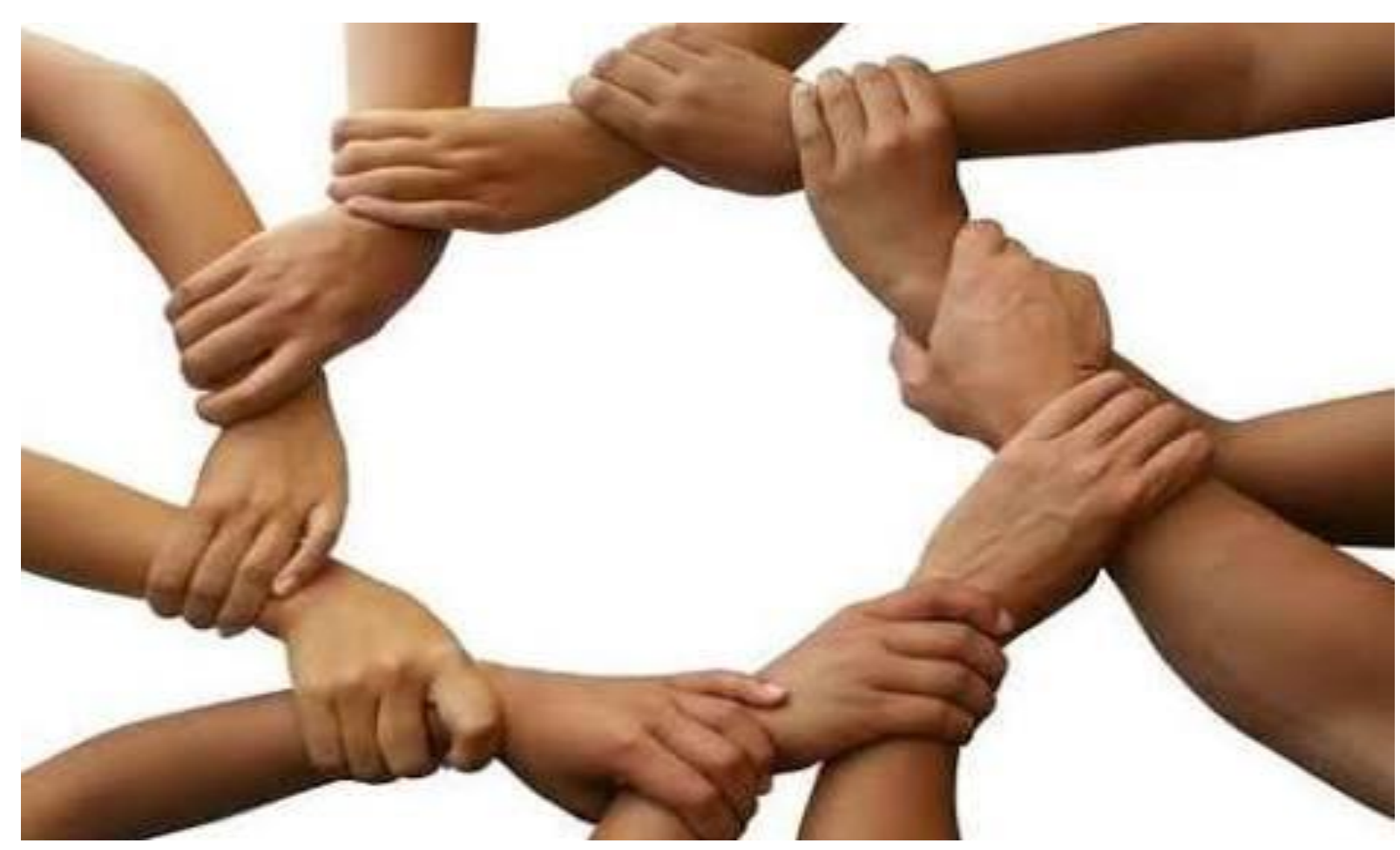

Figura 12 - Fotografia selecionada pela Enfermeira Obstétrica Gisele ${ }^{4}$

O modelo de atenção obstétrica predominante em nosso país é caracterizado pela institucionalização do atendimento, com adoção de práticas intervencionistas e muitas vezes marcado pela impessoalidade. Isso gera uma realidade assustadora de partos operatórios e práticas com pouca ou nenhuma evidência científica (COSTA, et al., 2013).

Consequentemente, ainda temos uma assistência à mulher deficitária, pois as parturientes nem sempre conseguem um acompanhante no momento do parto e

\footnotetext{
${ }^{4}$ Imagem disponível em < http://tusaludylanutricion.blogspot.com.br/2013/04/equipo-multidisciplinario-enpuestos-de.html >. Acesso durante o período de coleta de dados.
} 
nascimento; logo, ficam sem nenhum tipo de apoio psicológico e emocional, tendo a companhia apenas de profissionais de saúde desconhecidos (SANTOS et al., 2011).

Com a implantação do Programa de Humanização no Pré-Natal e Nascimento pelo MS em nosso país no ano 2000, alinhado com a OMS e baseado em evidências científicas, houve a recomendação de que toda parturiente deve ser acompanhada por pessoas em quem confia e com quem se sinta à vontade (BRASIL, 2002b; OMS, 1996; BRASIL, 2001).

Em 2005, entrou em vigor a Lei que garante às parturientes o direito à presença de um acompanhante durante o trabalho de parto, parto e pós-parto imediato. Desta forma, as instituições tiveram que se adaptar para preservar o direito das famílias de estarem presentes no momento do nascimento (BRASIL, 2005).

A palavra grega doula se refere a mulheres que possuem um treinamento específico para transmitir conforto físico e emocional à parturiente. Essas ações estão focalizadas em esclarecer os fenômenos que acontecem na atenção ao parto, elogios pelos progressos, contato físico ou exclusivamente ser uma presença amiga (COSTA et al., 2013; TAKEMOTO; CORSO, 2013; SILVA et al., 2012; BRUGGEMANN et al., 2007).

Numerosas instituições de saúde têm adotado a presença da doula como parte integrante da equipe, à medida que essas pessoas possuem um treinamento prévio e específico para promover conforto físico e emocional à parturiente, não realizando procedimentos e nem interferindo nas ações da enfermeira obstétrica (SANTOS; NUNES, 2009; SILVA et al., 2012; BRUGGEMANN et al., 2007; COSTA et al., 2013). 
Vários estudos demonstram que, quando a parturiente tem apoio contínuo durante o processo de parturição, há redução da duração do trabalho de parto, de intervenções medicamentosas na condução do trabalho de parto e na taxa de cesariana e, consequentemente, aumento no número de partos vaginais. Além disso, a mulher se sente mais satisfeita (ZANDT, et al., 2016; HODNETT et al., 2013; HODNETT, 2008; COSTA et al., 2013).

Neste sentido, as enfermeiras obstétricas realçaram a importância da presença do acompanhante e da doula como um fator positivo para o atendimento à parturiente, o que ficou evidenciado na Figura 13, selecionada pela Enfermeira Obstétrica Beatriz.

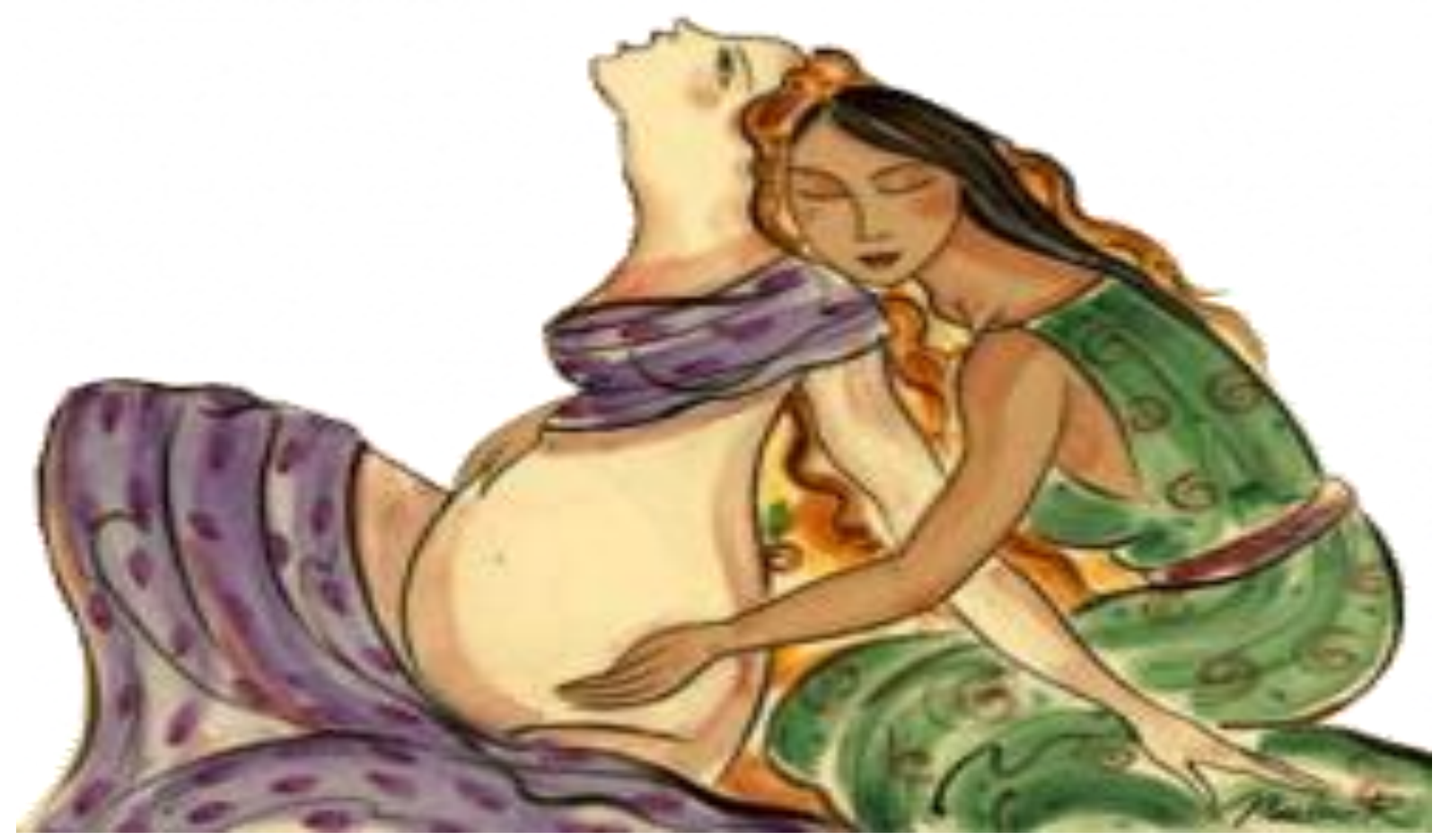

Figura 13 - Fotografia selecionada pela Enfermeira Obstétrica Beatriz ${ }^{5}$

\footnotetext{
5 Imagem disponível em 〈http://www.infoescola.com/medicina/enfermagem-obstetrica/〉. Acesso durante o período de coleta de dados.
} 
Na Maternidade, devido ao atendimento ser voltado para o SUS, não temos o trabalho da doula, elas são funcionárias particulares. Existe um projeto de doulas voluntárias, mas isso não está disponível ainda. Muitas vezes devido à segurança que passam para a paciente, elas preferem as doulas aos maridos, e as mesmas permanecem até o nascimento do bebê e na hora do parto deixamos o pai entrar... (Beatriz).

A doula cria um vínculo com a paciente durante a gestação, isso gera confiança... (Rose).

O acompanhante propicia momentos de conforto para a gestante, pois nem sempre a equipe pode estar presente... (Denise).

O comum é que nem todas as gestantes tem acesso a uma doula ou tenham um acompanhante. Então, na maioria das vezes, as demais gestantes se questionam porque umas tem doula de companhia e outras não... (Beatriz).

A doula cria um vínculo com a paciente antes mesmo do parto. Outro ponto importante é que algumas gestantes confundem a finalidade da doula de companhia com proteção, caso algo de errado ela terá um "escudo" $e$ esse não é o objetivo. O principal objetivo é fazer com que a gestante encare a parturição como natural $e$ prazeroso... (Gabriela). 
O que somos como ser humano é resultado das relações que homens e mulheres têm construído historicamente (EAGLETON, 2011). Logo, é possível afirmar que é no processo de trabalho que homens e mulheres, em convívio mútuo e com o meio, constroem-se diante dos outros e entre si, acrescentam à natureza tudo aquilo a que denominamos cultura. Logo, considera-se o trabalho como uma prática social; desta forma nos constituímos como sujeitos, nos educamos, aprendemos e visualizamos as relações que produz e reproduz a sociedade em que vivemos e participamos (GOMES, 2010).

Na discussão em grupo, as enfermeiras obstétricas realçaram a importância do estudo constante como forma de manter-se sempre atualizadas e praticarem a educação continuada nas equipes que gerenciam. Ao realizarem cursos e aprimoramentos, ficam aptas a prestarem uma assistência obstétrica mais segura e humanizada, assim como apresentado nas Figuras 14 e 15.

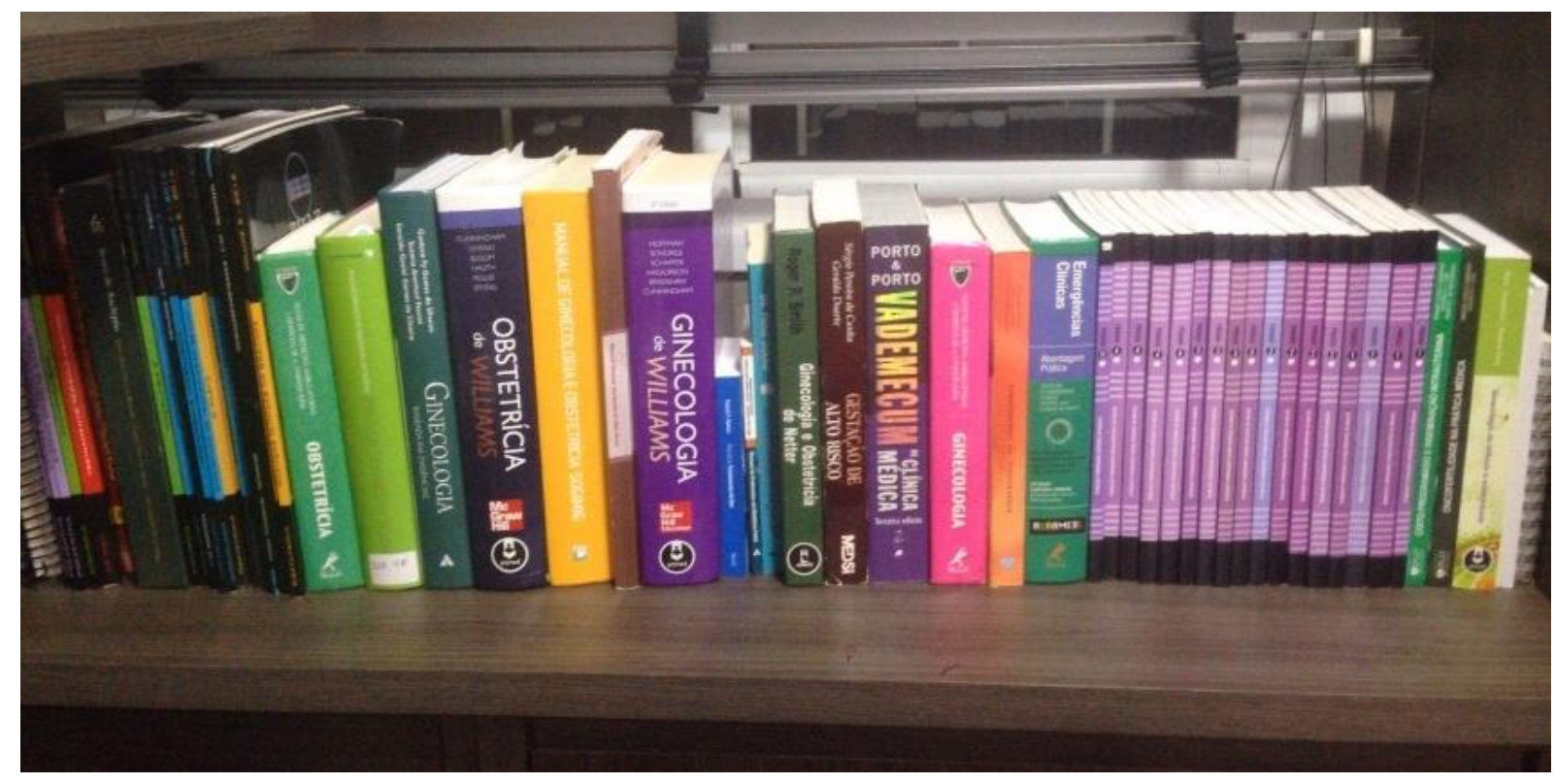

Figura 14 - Fotografia produzida pela Enfermeira Obstétrica Rose 
Necessitamos de conhecimento constantemente devido às atualizações... (Clara).

Sabemos que devemos sempre estar estudando, somos eternas educadoras e para transmitir o conhecimento, devemos estudar sempre... (Maria).

Na maternidade onde trabalho, sempre fazemos cursos de atualização, acho muito importante, pois sempre temos que renovar os conhecimentos e práticas, para assistir melhor... (Beatriz).

Precisamos sempre estar estudando, atuando de maneira a auxiliar os profissionais que estão começando, internos de enfermagem...(Denise).

Os profissionais de enfermagem devem ser capazes de aprender continuamente, tanto na sua formação quanto na sua prática assistencial. Neste sentido, as enfermeiras obstétricas devem aprender a ter responsabilidade e compromisso com a sua educação e treinar e possibilitar estágios para a formação das futuras gerações profissionais, de forma a possibilitar condições de benefícios mútuos entre os profissionais dos serviços de saúde, até mesmo desenvolvendo a mobilidade acadêmica/profissional, a formação e cooperação por meio das redes nacionais e internacionais, conforme rege a Resolução do Conselho Nacional de Educação e Câmara de Educação Superior no 3, de 7 de Novembro de 
2001, que institui as Diretrizes Curriculares Nacionais do Curso de Graduação em Enfermagem (CONSELHO NACIONAL DE EDUCAÇÃO, 2001).

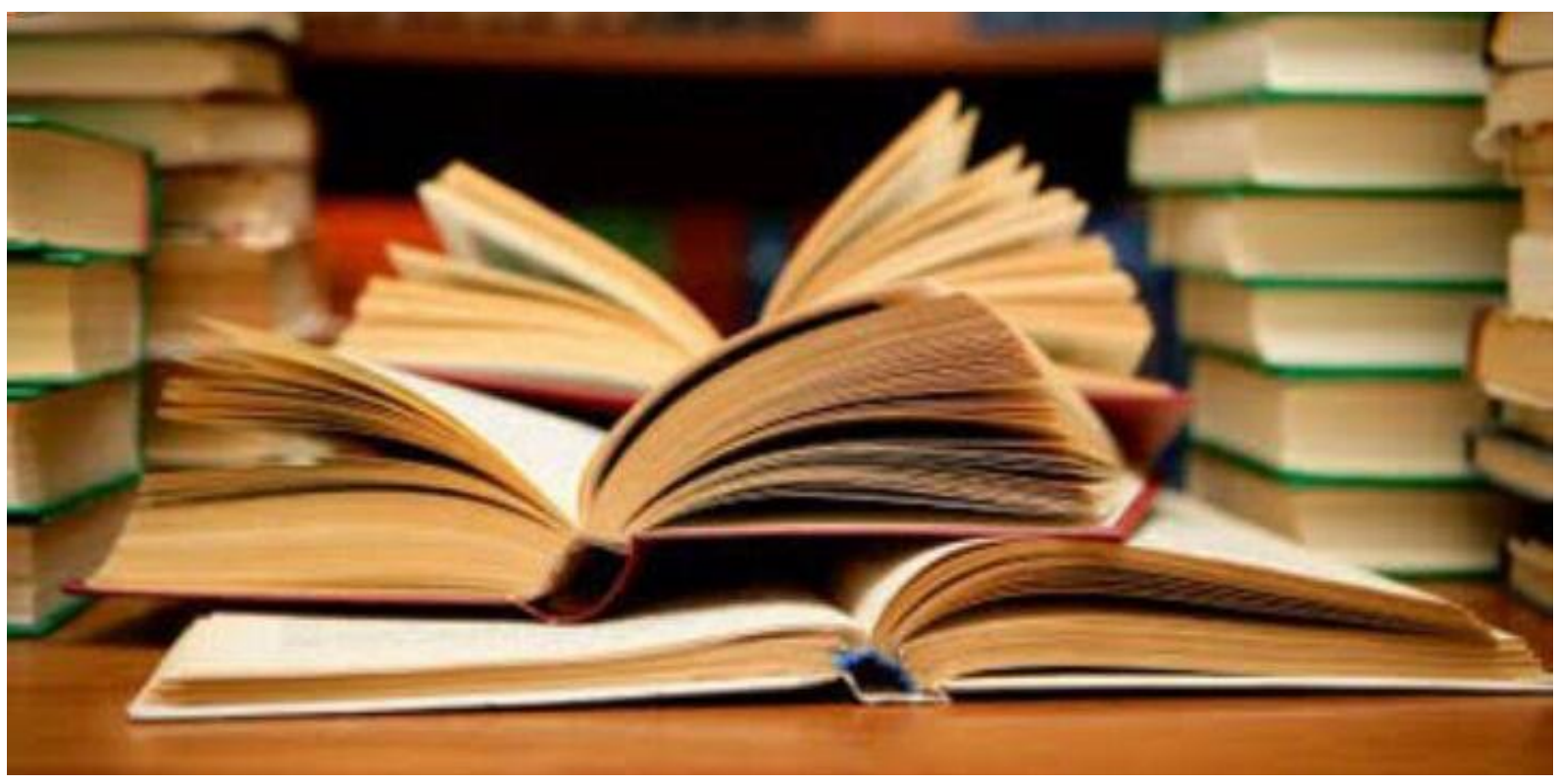

Figura 15 - Fotografia produzida pela Enfermeira Obstétrica Gabriela ${ }^{6}$

As enfermeiras obstétricas, assim como todos os profissionais de saúde e a maioria dos profissionais, em sua prática diária, convivem com um modelo mecanicista e biomédico cartesiano, em um contexto determinado e historicamente liderado por médicos, pois ainda vivemos e convivemos em um modelo linear de estudo e prática profissional (MORIM, 2001).

\footnotetext{
${ }^{6}$ Imagem disponível em <http://www.educandoenigualdad.com/>. Acesso durante o período de coleta de dados.
} 


\subsubsection{Fatores dificultadores na assistência da enfermeira obstétrica: fragilidades afloradas nos cenários de admissão, pré-parto, parto e pós-parto imediato}

A partir de meados do século passado, com a transferência dos partos domiciliares para os atendimentos em unidades hospitalares, houve uma ruptura na cultura do nascimento natural, gerando um aumento gradativo de procedimentos cirúrgicos, entre eles a cesariana. Desta forma, a medicina passou a dominar a assistência prestada ao trabalho de parto e nascimento, modificando a cultura neste ambiente, desprivilegiando de poder a prática assistencial da enfermagem.

Durante as discussões em grupo, as enfermeiras obstétricas mencionaram que a falta de prática assistencial ao parto é um fator de fragilidade da assistência prestada por elas, pois não se sentem seguras por terem realizados poucos partos na especialização; desta forma, não se envolvem na assistência ao parto propriamente dita.

Um dos fatores levantados por elas é a deficiência de carga horária adotada nos programas de pós-graduação latu sensu, geralmente insuficiente para a realização de partos, o que pode significar uma formação de profissionais sem que tenham conseguido alcançar as competências e habilidades mínimas para a titulação em enfermagem obstétrica e atuar com segurança. Desta forma, ficaram carentes na formação.

Segundo estudo realizado por Lima et al. (2015), no campo do centro obstétrico, as enfermeiras obstétricas consideram que a autonomia profissional está relacionada ao conhecimento e às competências profissionais, assim como à cultura organizacional e ao respaldo outorgado pelos gestores das instituições em que trabalham. Logo, se creditam não terem adquirido as competências essenciais durante a formação, subentende-se que não possuem autonomia para realizarem a assistência, intensificando desta 
forma a fragilidade apresentada na assistência ao parto descrita pelas enfermeiras participantes deste estudo.

Entendendo as deficiências apresentadas na formação das enfermeiras obstétricas, o Conselho Federal de Enfermagem, na Resolução no 516 de 2016, vem normatizar a atuação e a responsabilidade do Enfermeiro, Enfermeiro Obstetra e Obstetriz na assistência às gestantes, parturientes, puérperas e recém-nascidos nos serviços de obstetrícia, Centros de Parto Normal e/ou Casas de Parto e demais locais onde ocorra essa assistência, e estabelecer critérios para registro de títulos de Enfermeiro Obstetra e Obstetriz no âmbito do Sistema Cofen/Conselhos Regionais de Enfermagem (CONSELHO FEDERAL DE ENFERMAGEM, 2016).

Esta resolução estabelece como critério mínimo para obtenção do título de Enfermeiro Obstetra a realização de, no mínimo, 15 consultas de Enfermagem pré-natais, 20 partos com acompanhamento completo do trabalho de parto, parto e pós-parto e 15 atendimentos ao recém-nascido na sala de parto (CONSELHO FEDERAL DE ENFERMAGEM, 2016).

Assim, o Conselho Federal de Enfermagem visa melhorar a formação das enfermeiras obstétricas e possibilitar maior envolvimento delas na assistência ao parto normal sem distócia, uma vez que estudos relatam dificuldades das enfermeiras obstétricas, conforme descreveu Monticelli et al. (2008). As enfermeiras obstétricas recém-formadas evidenciaram dificuldades para atuação na especialidade, relatando insegurança quanto à realização de procedimentos técnicos adquiridos pela especialidade. É importante salientar que o aumento crescente da hospitalização, a incorporação de tecnologias e aumento crescente de cesarianas 
são fatores que contribuem negativamente para a assistência à mulher no processo do nascimento.

Assim, temos relatos dos sujeitos da pesquisa que vem ao encontro do que foi apontado acima, retratado também na Figura 16.

A prática de partos pelas enfermeiras obstétricas traz mais facilidades, mas depende muito, por exemplo eu fiz poucos partos, isso dificulta muito minha segurança ao realizar partos hoje... (Maria).

Ter realizado mais partos na especialização facilitaria todo o trabalho de assumir o parto agora. Se tiver uma carga horária maior poderemos ter uma atuação prática melhor na assistência... (Beatriz).

A formação de profissional é moldada, não é direcionada para a prática, não é voltada ao natural... (Gabriela)

Não me sinto segura em realizar partos normais, sei que aprendi, mas fiz apenas 3 partos na especialização, é роисо... (Luiza). 


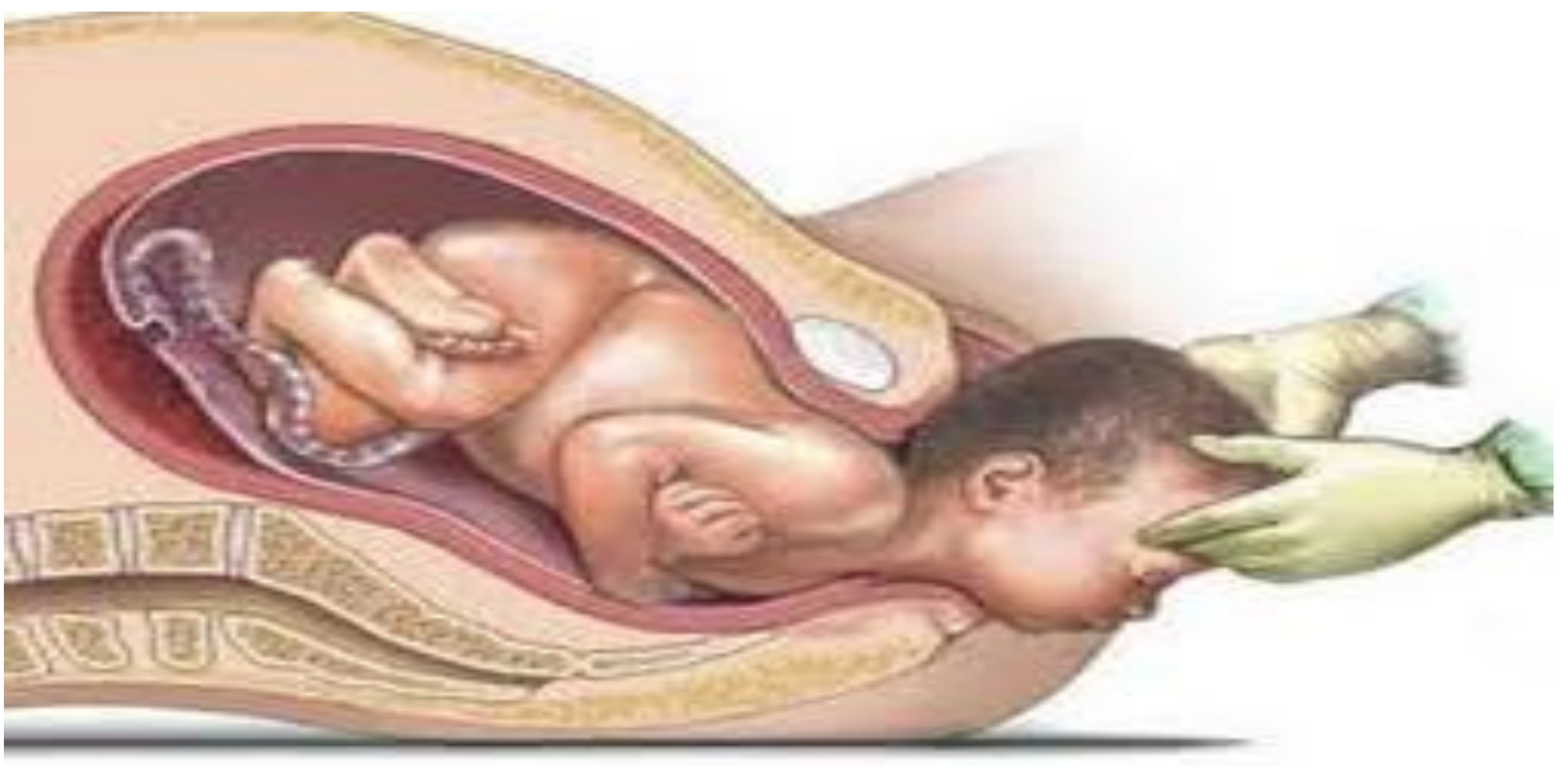

Figura 16 - Fotografia produzida pela Enfermeira Obstétrica Beatriz ${ }^{7}$

No grupo focal, as enfermeiras obstétricas destacaram a assistência pré-natal inadequada como uma fragilidade para a assistência obstétrica eficaz e para o desenvolvimento pleno da sua atuação.

Logo, a assistência pré-natal de qualidade é evidenciada como o primeiro ponto a ter seu objetivo traçado quando se necessita reduzir as taxas de mortalidade materna e perinatal. O MS, em especial a área temática da saúde da mulher, desenvolveu políticas públicas com a finalidade de aumentar o acesso aos serviços de saúde, à cobertura e à qualidade do período pré-natal. Logo, a assistência prestada pelas enfermeiras obstétricas nos serviços de saúde deverá estar voltada para a qualidade, vencendo assim os obstáculos para o Brasil atingir a meta do $5^{\circ}$ objetivo do desenvolvimento do milênio da Organização das Nações Unidas (BRASIL, 2012c, BASSO et al., 2012; COSTA et al., 2013; SILVA et al., 2015; PRUDÊNCIO; MAMEDE, 2015).

\footnotetext{
7 Imagem disponível em < http://espanol.babycenter.com/34-semanas-de-embarazo>. Acesso durante o período de coleta de dados.
} 
Várias pesquisas têm demonstrado que o número insuficiente de consultas de pré-natal é um fator de risco para a morbimortalidade fetal e neonatal, o que poderá aumentar a ocorrência de parto prematuro, caso não ocorram ações no tempo apropriado da gestação (SOARES; MENEZES, 2010; BEECKMANN et al., 2013; MARTINELLI et al., 2014).

O MS, com o Programa de Humanização ao Parto e Nascimento, determinou procedimentos mínimos que todas as gestantes devem receber durante as consultas de pré-natal, além do número de vezes que devem comparecer às consultas e o número de solicitações de exames laboratoriais. Em estudo realizado em Rio Grande (RS) por Saavedra e Cesar (2015), ficou evidenciado que um quarto das gestantes realizou o pré-natal de forma inadequada, isto é, realizaram menos que 6 consultas e não realizaram todos os exames laboratoriais.

Assim, é recomendado pelo MS que o início do pré-natal se dê no primeiro trimestre e que tenha no mínimo seis consultas, sendo uma no primeiro trimestre, duas no segundo e três no terceiro, além de uma consulta no período puerperal, com até 42 dias após o parto (BRASIL, 2012c; SILVA et al., 2013).

Com esta iniciativa, o governo busca diminuir as altas taxas de morbimortalidade materna e perinatal, priorizando medidas para melhoria do acesso à rede de saúde, da qualidade da assistência ao pré-natal, parto e puerpério. O que é percebido na prática é que estes protocolos e programas não estão assegurando a realização do mínimo de consultas em vários estados do Brasil (PARADA, 2008; COUTINHO et al., 2010; ANDREUCCI; CECATTI, 2011). 
A implantação da Rede Cegonha visa complementar o PHPN e desta forma estimular o estabelecimento de um novo modelo de atenção à saúde materna e infantil, garantindo assim a acessibilidade, acolhimento, qualidade e resolutividade, consequentemente, a diminuição dos índices de mortalidade materna e infantil (BRASIL, 2011b).

O cartão da gestante foi criado em nosso país em 1988 com o objetivo de armazenar informações, simplificar a comunicação entre os profissionais de saúde que atendem a mulher no pré-natal e na maternidade. Assim, após a sua implantação, fomentou dados para o Sistema de Informações sobre Nascidos Vivos e fornece dados para fomentar as políticas públicas brasileiras. A qualidade da assistência prestada no pré-natal pelos profissionais de saúde e instituições é também avaliada pelos registros realizados no cartão de pré-natal. A Figura 17, coletada por uma das enfermeiras participantes do estudo, ilustra um cartão de pré-natal com poucas informações da gestação e sem anotações sobre a realização das consultas, o que vai em sentido contrário ao recomendado pelas políticas públicas implantadas em nosso país (SANTOS NETO et al., 2012). 


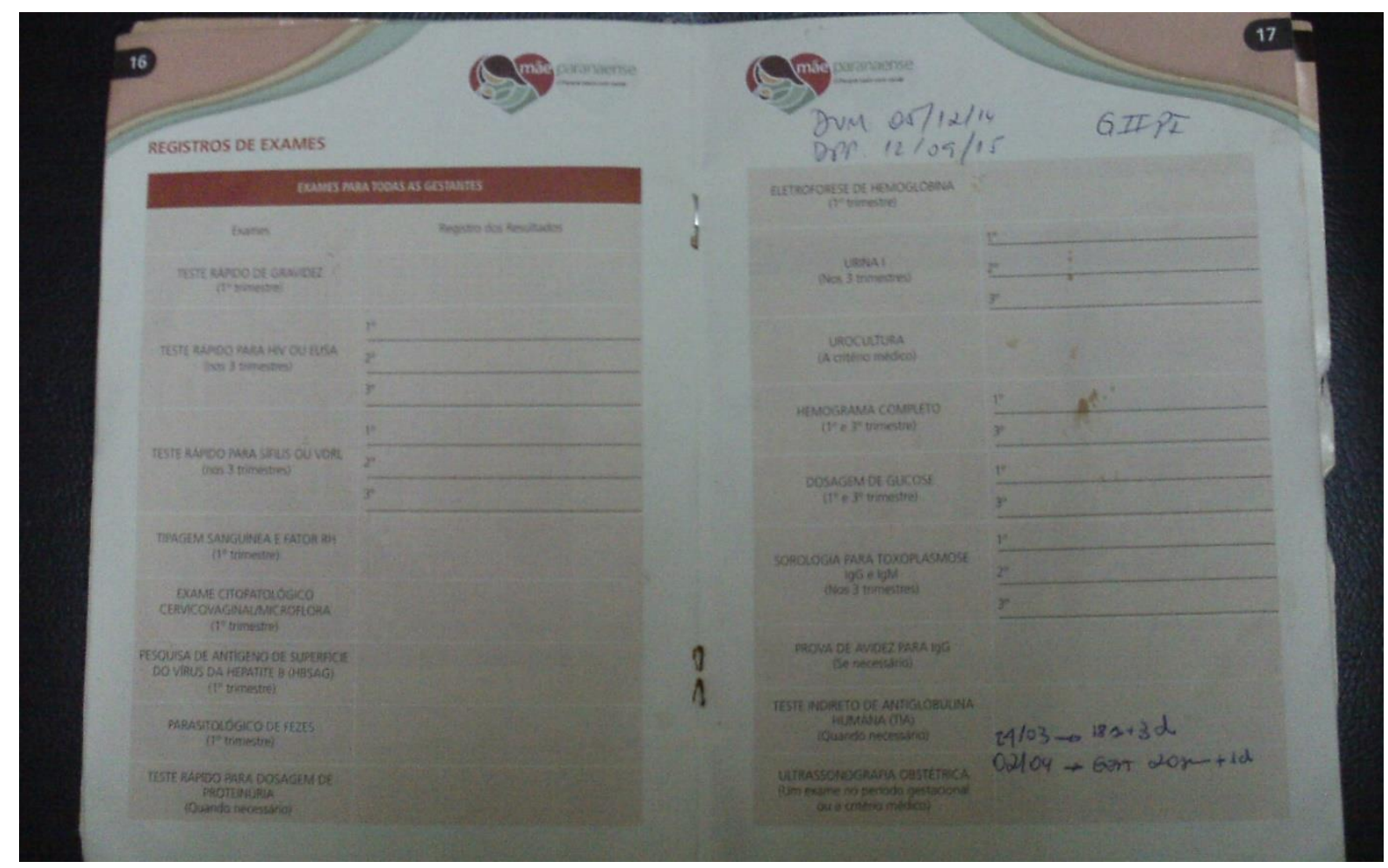

Figura 17 - Fotografia produzida pela Enfermeira Obstétrica Maria

Sabe-se que as políticas de saúde contribuem para a implantação e o controle do pré-natal, porém, além desses fatores, a cultura da usuária tem um papel definidor da necessidade deste acompanhamento, visto que é preciso que a gestante sinta necessidade desta prestação de serviço para a sua adesão e este comprometimento está diretamente relacionado à cultura vivida no meio social.

Nos depoimentos abaixo pode-se constatar como as enfermeiras obstétricas avaliam como importante as informações contidas no cartão da parturiente.

Em relação a assistência pré-natal pelo SUS, na carteirinha temos todas a as informações necessárias, desde USG, mas quanto às orientações referentes ao parto ainda são muito falhas... (Clara). 
Carteirinhas de pré-natal mal preenchidas ou em branco dificultam muito nosso trabalho, porque na maternidade não é hora de colocar todo pré-natal em dia, temos que focar esforços para o nascimento... (Beatriz).

É muito triste verificar uma gestação no final, no momento de parir e encontrar um cartão de pré-natal em branco, sem a realização das consultas... (Gabriela).

A falta de acompanhamento adequado nas consultas de pré-natal favorece a falha na detecção precoce de síndromes hipertensivas, principal causa de morte materna em nosso país, responsável por aproximadamente $25 \%$ dos casos de óbito no período gravídico puerperal, além de elevar a chance de intervenção na gestação no período pré-termo, havendo uma forte tendência a prematuridade (VETTORE et al., 2013).

Conforme ilustra a Figura 18, outras doenças que também podem ter seu diagnóstico atrasado ou não identificado são o HIV e a Sífilis. A infecção por sífilis congênita figura como um grande desafio para a saúde pública, pois possui uma alta taxa de transmissibilidade; logo, pode gerar resultados prejudiciais para a gestante e para seu filho (ANDREUCCI; CECATTI, 2011; KHAN et al., 2006). 


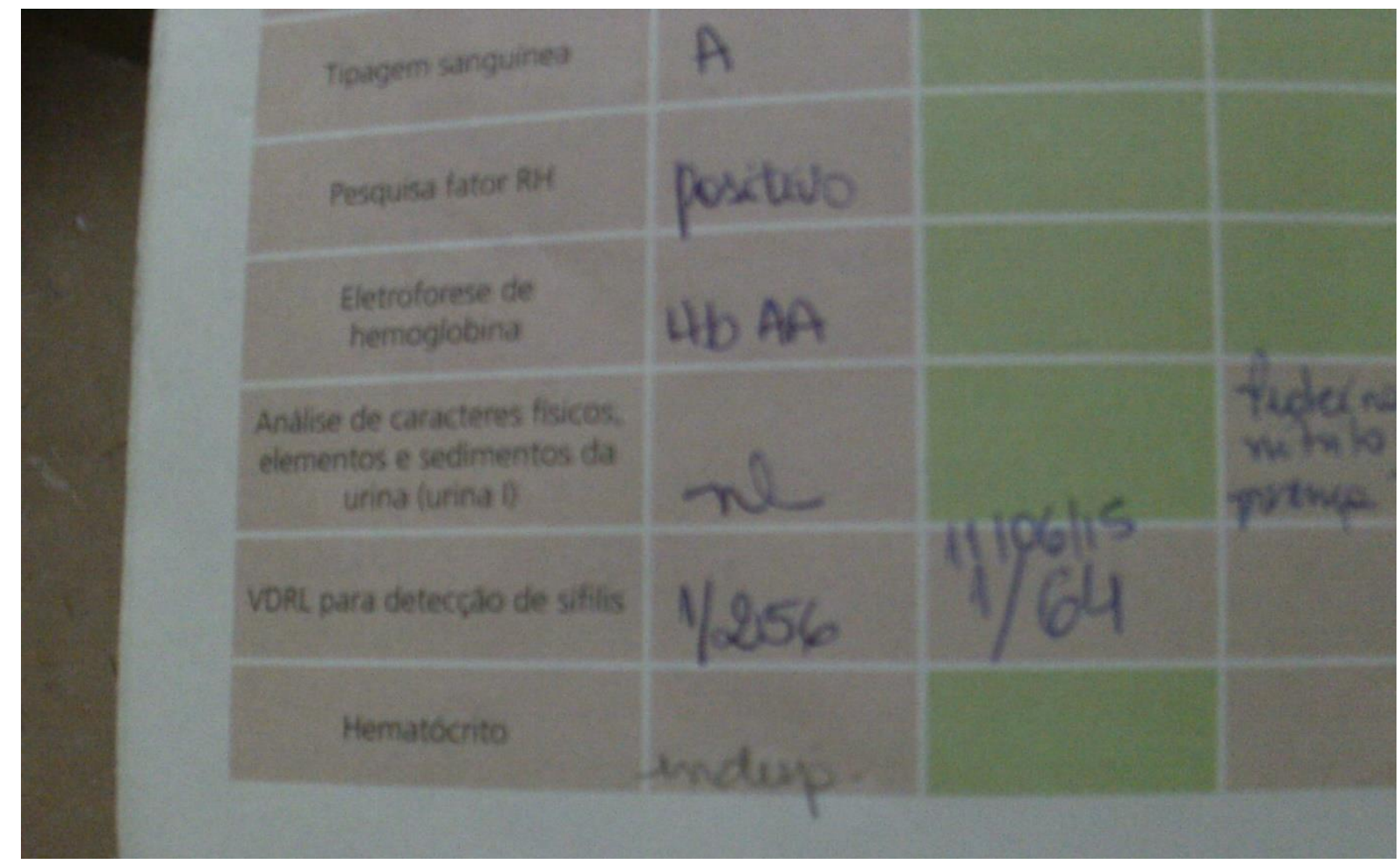

Figura 18 - Fotografia produzida pela Enfermeira Obstétrica Maria

No pré-natal deveriam receber mais orientações, realização de exames, essas coisas. E quando for tratar uma paciente com sífilis, deveriam ficar atentos ao tratamento adequado... (Maria).

A identificação de doenças sexualmente transmissíveis durante o pré-natal pelo convênio particular é péssima, parece que eles têm um preconceito em pedir os exames necessários... (Rose).

Os relatos acima demonstram que as enfermeiras obstétricas apontam como um fator dificultador o caráter insignificante ou mesmo velado que é dado às doenças sexualmente transmissíveis tanto pelos profissionais de saúde como pelos próprios usuários 
do sistema. Este resultado pode ser considerado como negligência ou ausência de conhecimento, por parte da usuária, dos possíveis riscos de infecção tanto para ela quanto para o recém-nascido, o que pode ser atribuído à falta de informações sobre a forma de transmissão das doenças sexualmente transmissíveis e a consequências para o feto, podendo gerar danos para toda a vida. Esta situação emerge da cultura local, isto é, do meio social em que a usuária vive e com que se relaciona.

Em se tratando da estrutura física, as enfermeiras obstétricas referiram encontrar dificuldades onde atuam, fator este demonstrado nas fotografias produzidas por elas, nas Figuras 19, 20, 21 e 22 respectivamente, em que é possível visualizar fragilidades nos espaços físicos e equipamentos sem manutenção utilizados na assistência.

A qualidade dos serviços de saúde e do cuidado na área da saúde está sujeita a uma articulação da cultura das instituições, do relacionamento em equipe multidisciplinar e das condições de infraestrutura. Há uma estruturação entre a aplicação dos conhecimentos e o uso de tecnologias, em sintonia com as equipes de saúde e os pacientes por eles assistidos (MAGLUTA et al., 2009; GABRIEL, et al., 2010).

A ambiência dos espaços da maternidade é regida pela Resolução da Diretoria Colegiada - RDC no 36 de 3 de Junho de 2008 (ANVISA, 2008), que define a estrutura necessária para a admissão, o trabalho de parto e parto e pós-parto imediato. Logo, destacamos as necessidades principais de infraestrutura que as instituições devem proporcionar, nos seguintes cenários:

- Admissão: um ambiente confortável de espera; receber atendimento inicial e orientações sobre os procedimentos a serem realizados; ter sua permanência garantida em caso de necessidade de observação; ter a transferência assegurada em caso de 
necessidade, com transporte adequado e após assegurar a existência de vaga no serviço de referência.

- Trabalho de parto: garantia da privacidade da parturiente e seu acompanhante; prover espaço para deambulação e movimentação ativa da mulher, quando ausente de complicações clínicas; possibilitar que os períodos clínicos sejam assistidos no mesmo ambiente; garantir à mulher condições de escolha das diversas posições no trabalho de parto.

- Parto e pós-parto imediato: garantir à mulher condições de escolher a melhor posição para parir; assegurar que os procedimentos adotados sejam baseados em avaliação individualizada e nos protocolos institucionais; possibilitar o controle da luminosidade, da temperatura e dos ruídos no ambiente; garantir que o atendimento imediato ao recém-nascido seja realizado no mesmo ambiente do parto, sem interferir na interação mãe e filho, desde que asseguradas a saúde de ambos; garantir que o recém-nascido não seja retirado do ambiente do parto sem identificação; prover a transferência do binômio, em caso de necessidade, seja realizada após assegurar a existência de vaga no serviço de referência, seja realizada com transporte adequado.

Independente da cultura organizacional hospitalar, uma estrutura física adequada (limpeza, organização, espaço físico, manutenções etc.) vai proporcionar melhores condições para o provimento de ações de humanização, diminuição de procedimentos desnecessários e sem evidência científica comprovada, maior satisfação da parturiente e de seu acompanhante. 


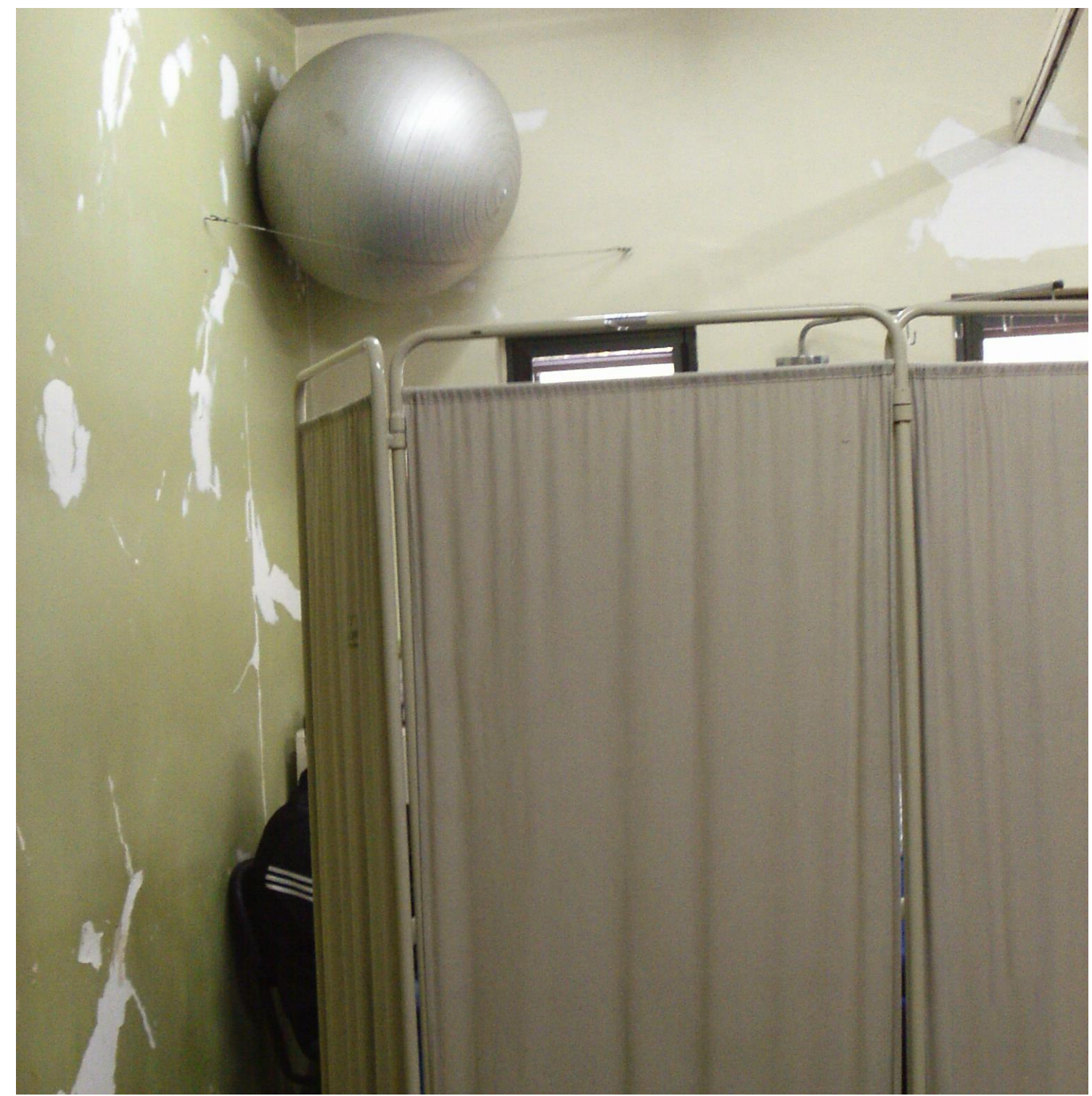

Figura 19 - Fotografia produzida pela Enfermeira Obstétrica Clara

Passamos a seguir aos relatos orais das enfermeiras obstétricas participantes deste estudo: frio, não favorece a humanização... (Maria). 
Na sala de parto, não há privacidade, todo mundo entra a qualquer hora, a mesa de parto está estragada, não é confortável... (Luiza).

Além da estrutura física precária, outra deficiência é a falta de manutenção dos equipamentos. Hoje mesmo tivemos um caso de uma paciente que precisou de transfusão de sangue e não conseguimos contato para solicitar o sangue porque o telefone. "pifou” pensei, vamos avisar pessoalmente, mas às vezes a paciente não tem esse tempo, ela simplesmente precisa de uma transfusão que, para conseguirmos realizar, é necessário o envolvimento de outras áreas e até mesmo os familiares, mas o telefone não funciona da forma correta! Esse tipo de deficiência dificulta a agilidade e eficácia do nosso trabalho... (Beatriz).

No hospital em que trabalho, precisamos de uma sala de parto maior, tipo uma sala de PPP, mas sempre tem alguém para se opor principalmente por questões hierárquicas, de enfermeiro para chefe do setor, somos barradas mesmo que a ideia seja excelente... (Clara).

Estamos aguardando a implantação da Rede Cegonha em nossa instituição, para conseguirmos atuar com a gestante e seu acompanhante com mais privacidade. Hoje os leitos são separados por biombos, não há individualidade, falta espaço e conforto... (Rose). 
Com a implantação da Rede Cegonha, as instituições de saúde com serviços de maternidade poderão receber recursos para implementarem mudanças nas estruturas físicas, garantindo assim melhores condições assistenciais. A Rede Cegonha conta com financiamento da União, dos estados, do Distrito Federal e dos Municípios. Assim, a União deverá garantir recursos para a construção, ampliação e reforma dos Centros de Parto Normal, Casas da Gestante, Bebê e Puérpera, e recursos para reforma da ambiência em serviços que realizam partos, garantindo também a compra de equipamentos e materiais.

A expectativa, após a implantação dessas melhorias, é que as instituições estejam planejadas para atuarem em ações de humanização e que, desta forma, ocorra melhoria na assistência e diminuição da morbimortalidade materna e neonatal.

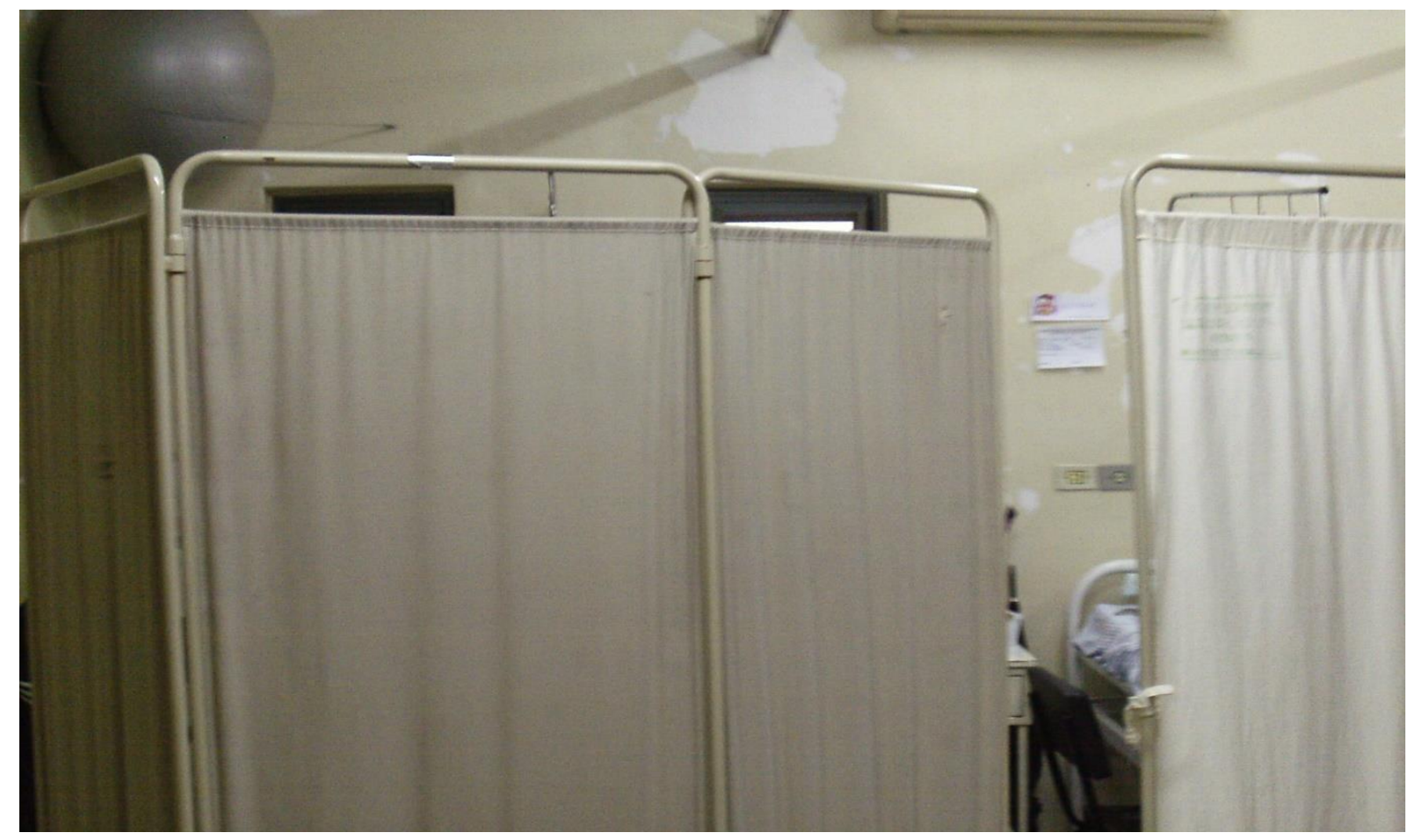

Figura 20 - Fotografia produzida pela Enfermeira Obstétrica Beatriz 


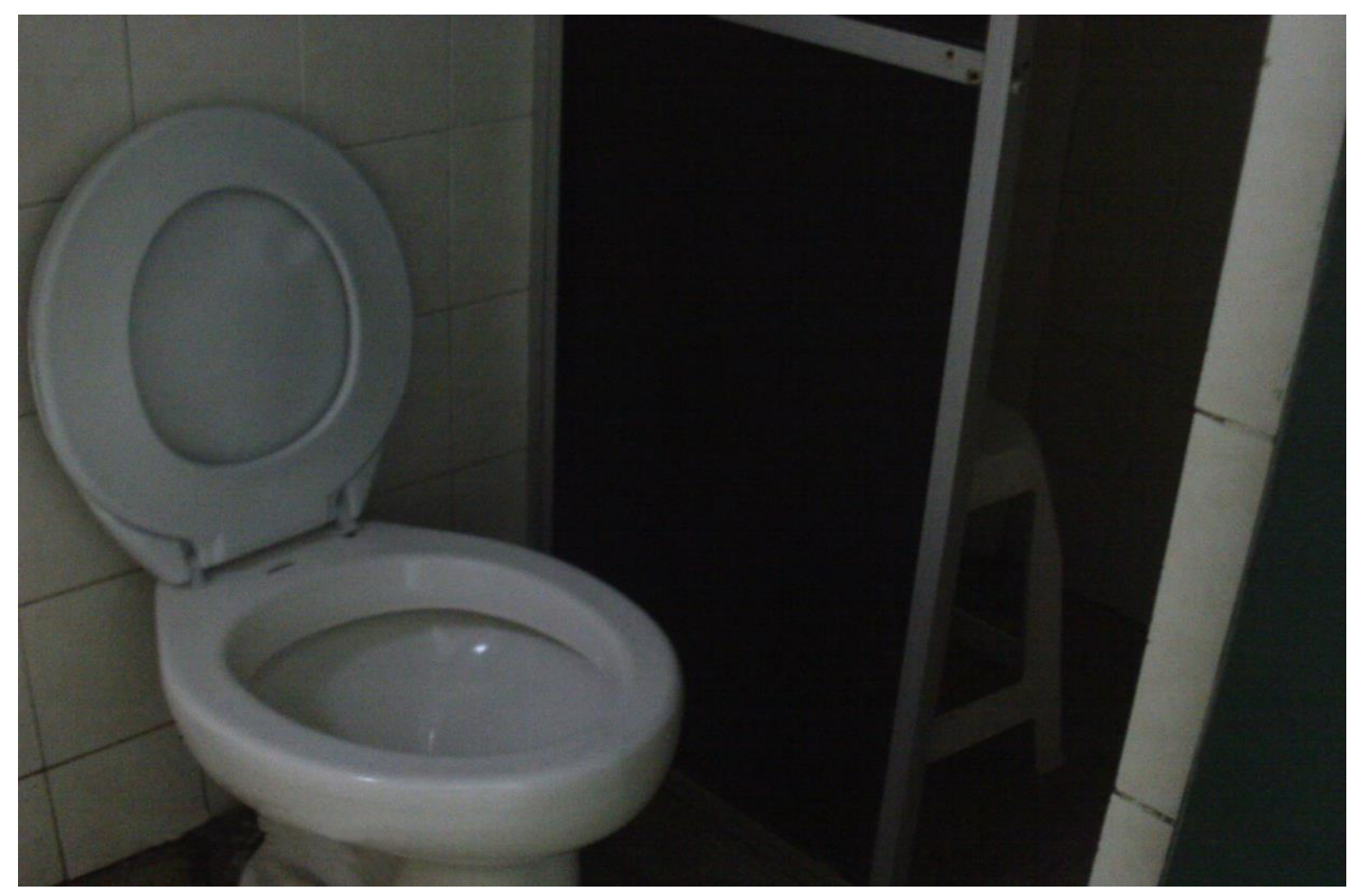

Figura 21 - Fotografia produzida pela Enfermeira Obstétrica Beatriz

Para Donabedian (1991), a estrutura física adequada é provavelmente o meio mais importante de proteção e promoção da qualidade do cuidado. Todavia não há uma relação direta entre uma boa estrutura e a assistência de qualidade prestada. O que acontece é que uma estrutura inadequada pode ser capaz de reduzir as chances de um cuidado de qualidade, embora não seja o responsável pelo produto final, pois este depende de vários fatores presentes no ambiente hospitalar, entre eles, a cultura inserida nas instituições. 


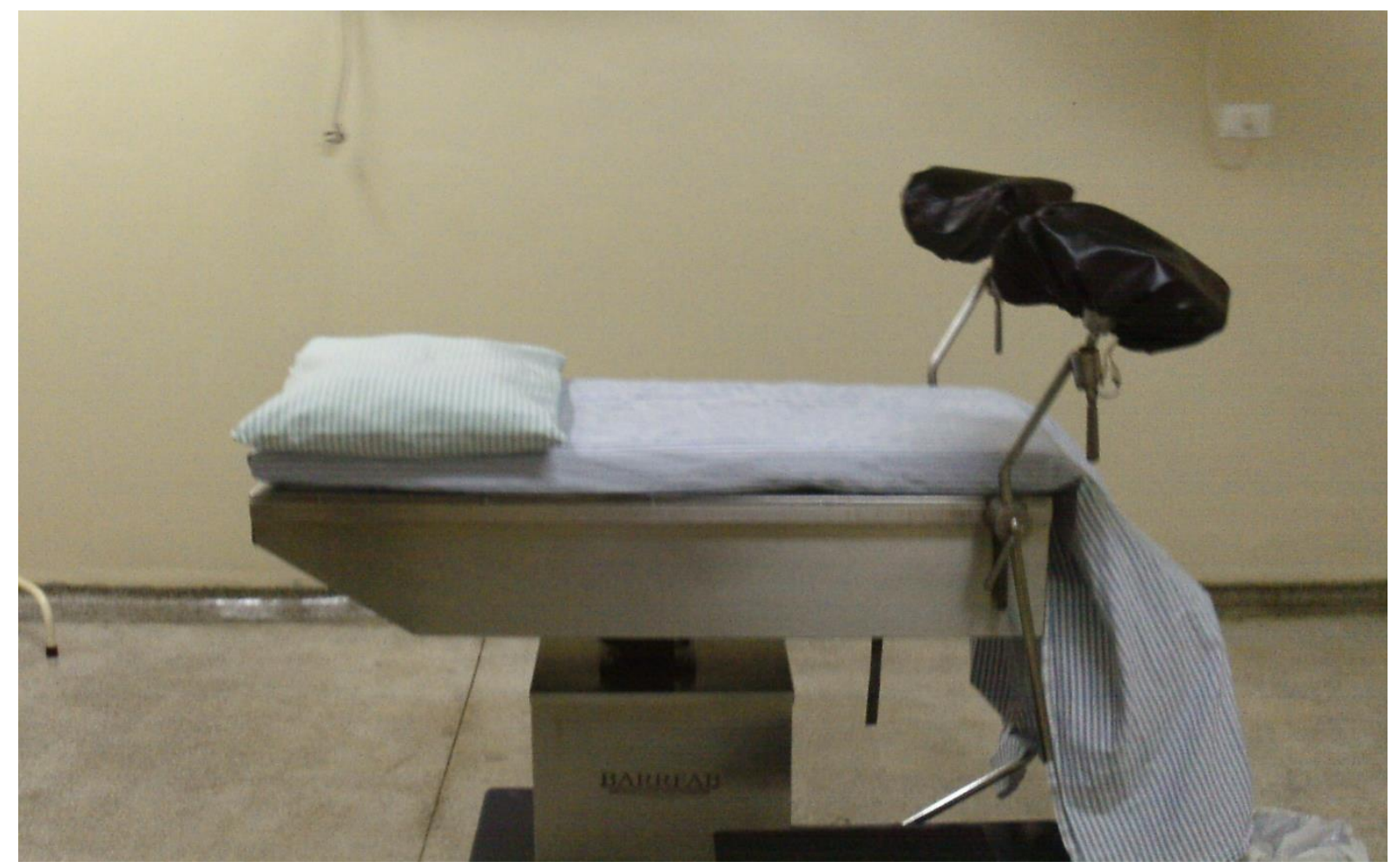

Figura 22 - Fotografia produzida pela Enfermeira Obstétrica Clara

Ao se tratar do tema, o contato mãe e recém-nascido foi apontado como um fator de fragilidade para a assistência prestada na sala de parto, pois a falta desse contato inicial é prejudicial para o binômio e não é recomendado nos programas e políticas públicas que vigoram em nosso país.

A efetivação do contato pele a pele entre mãe e filho é motivo de muitos trabalhos científicos, que fundamentam os benefícios fisiológicos e psicossociais para o binômio. Esta relação entre mãe e filho deve ser estimulada precocemente, desde os primeiros minutos de vida, devendo ser respeitada a cultura, a individualidade e o encanto deste momento (ALMEIDA; MARTINS FILHO, 2004; CRUZ et al., 2007).

Este primeiro contato, que acalma o bebê e a mulher que acaba de se tornar mãe ou de aumentar a família, deve ser tranquilo, sereno e prolongado. Neste momento 
mágico, ocorre a estabilização da corrente sanguínea, dos batimentos cardíacos da mãe e bebê, diminuição do estresse do nascimento para o bebê e preservação de seu aquecimento, por aproveitar o calor de sua mãe (ALMEIDA; MARTINS FILHO, 2004; WHO, 2006; MATOS et al., 2010).

Logo, ao aproximar mãe e bebê precocemente, há o desenvolvimento de sentimentos positivos, uma identificação mútua; é uma prática potencializadora para o estabelecimento do apego, já que o contato na sala de parto dá continuidade ao vínculo que começou na vida intrauterina e, na vida extrauterina, é aprendido e constituído no desenrolar dos primeiros anos de vida, além de ser indispensável para a saúde mental de todos os indivíduos (SKLUS et al., 2000; BOWLBY, 2006).

É relevante acrescentar que, neste momento inicial de contato, há estímulo de mecanismos sensoriais, hormonais, fisiológicos, imunológicos e comportamentais que garantirá o maior vínculo entre pais e filhos, favorecendo desta forma a diminuição da mortalidade infantil, existência de maus tratos e abandono (CHAGAS; MONTEIRO, 2007; ROLIN et al., 2008; BOCCOLINI et al., 2011; FUCKS, 2015).

Assim, a cultura das instituições deve estar voltada para o favorecimento deste contato precoce de maneira a proporcionar o equilíbrio necessário. Os profissionais de saúde desempenham papel de grande significado para efetivar o vínculo afetivo saudável e sólido entre mãe e filho, uma vez que atuam diretamente na assistência, desenvolvendo ações com a equipe multidisciplinar e garantindo assim o contato precoce para o binômio (ROSA et al., 2010; SOUZA et al., 2013). 
É muito difícil, em hospital terciário pois não conseguimos estabelecer um vínculo com a mãe logo no nascimento, e eles justificam dizendo que ali é uma maternidade de alto risco. Em média o Rn fica 2 a 3 horas longe da mãe... (Clara).

Se formos pensar na assistência, a sala de atendimento ao recém-nascido separada do quarto da mãe é ruim pra mãe, quebra o vínculo, vai na contramão da humanização... (Lia).

É muito triste quando não conseguimos fazer o contato inicial com a mãe. O nascimento ainda é cercado de muitos procedimentos e burocracia... (Maria).

De acordo com estudos realizados por Odent (2003), a primeira hora após o nascimento é primordial para o desenvolvimento da capacidade de amar. É neste momento que acontecem mudanças fisiológicas importantes: há liberação de ocitocina, o "hormônio do amor", em conjunto com a prolactina, o "hormônio da maternidade", o que traduz o contato pele a pele e olho no olho como um momento quando há maiores chances de estabelecimento de apego, interação e amor. Desta forma, o meio cultural pode interferir nessa condição quando não estimula este apego, utiliza sedativos, analgésicos e anestésicos de forma indiscriminada, influenciando a capacidade de amar de mãe e filho.

A fotografia abaixo, Figura 23, mostra um berço aquecido, simbolizando assim a distância entre o berço e o leito materno. 


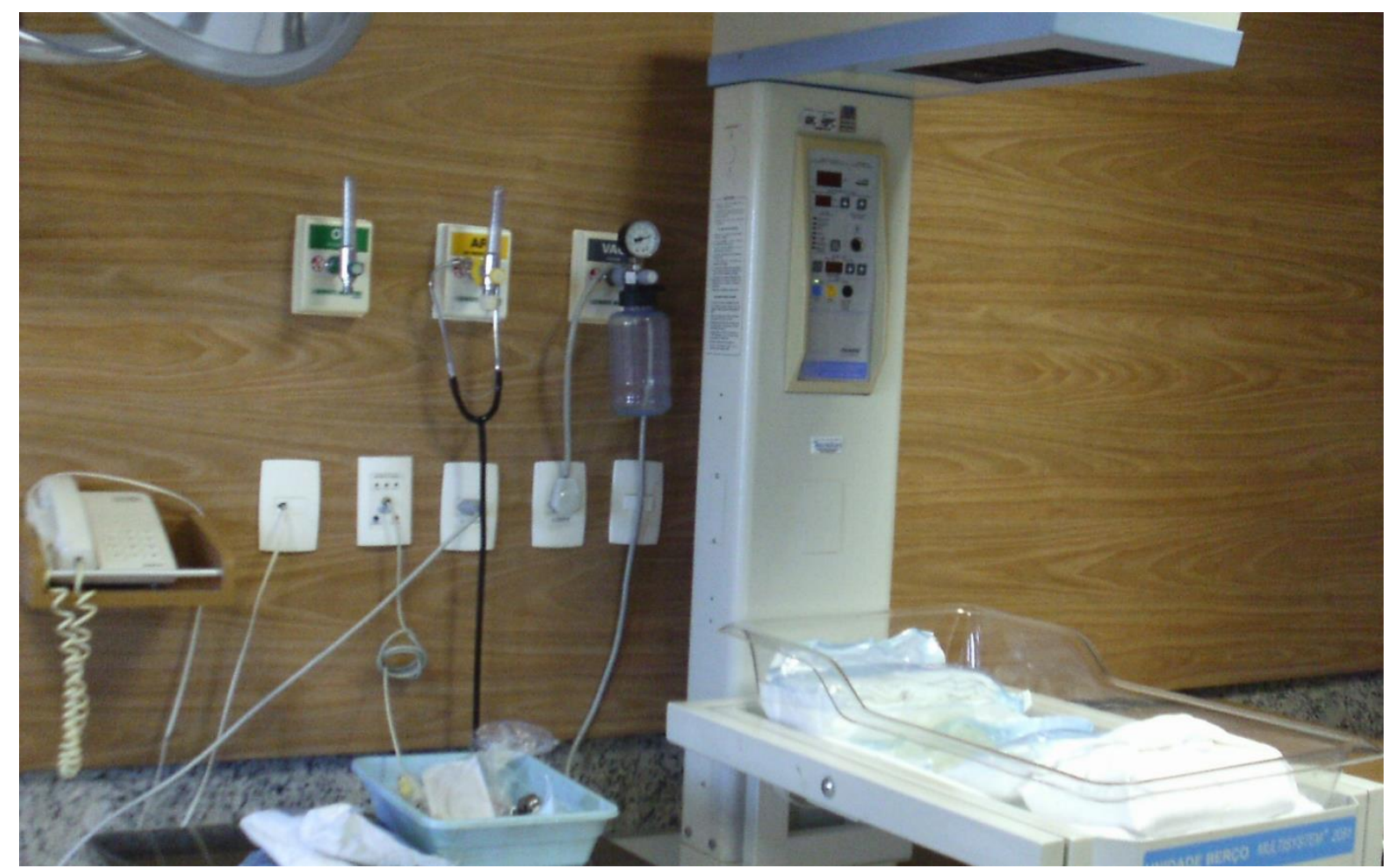

Figura 23 - Fotografia produzida pela Enfermeira Obstétrica Eva

A tecnologia da informação é uma ferramenta que gradualmente está difundida em nossa atualidade, devido à globalização, com rápida evolução nas diversas áreas, na indústria, no comércio, na educação e saúde. Assim, o conceito de tecnologia de informação envolve a utilização de hardware e software, telecomunicações, automação, recursos de multimídia, para fornecer dados, informações e obter conhecimento (WEIL, 1992; LUFTMAN et al., 1993).

Diversas instituições de saúde buscam informatizar processos a fim de permitir automação e integração e a diminuição da burocracia. A informatização dos dados de saúde deve auxiliar os profissionais de saúde na tomada de decisão, melhorando os processos, otimizando os recursos financeiros e atenuando o tempo de internação dos pacientes. 
A resolução no 1638 do Conselho Federal de Medicina de 10 de julho de 2002 define o prontuário como documento único, formado por um conjunto de informações, sinais e imagens registradas, constituídas segundo fatos, acontecimentos e situações sobre a saúde do usuário e a assistência contínua prestada a ele. Tem caráter legal, sigiloso e científico (CONSELHO FEDERAL DE MEDICINA, 2002).

Uma forma característica oriunda da gestão de informação é o prontuário eletrônico, que consiste de um conjunto de bancos de dados relacionados entre si, que permitem armazenar, recuperar e analisar todos os dados clínicos produzidos pela estada do paciente na instituição, tais como dados de identificação, sinais e sintomas, resultado de exames, tratamento medicamentoso, vacinação, procedimentos cirúrgicos, entre outras (BEZERRA, 2009; PINOCHET, 2011; ALVES et al., 2016). As Figuras 24 e 25 abaixo, retratam os prontuários não informatizados.

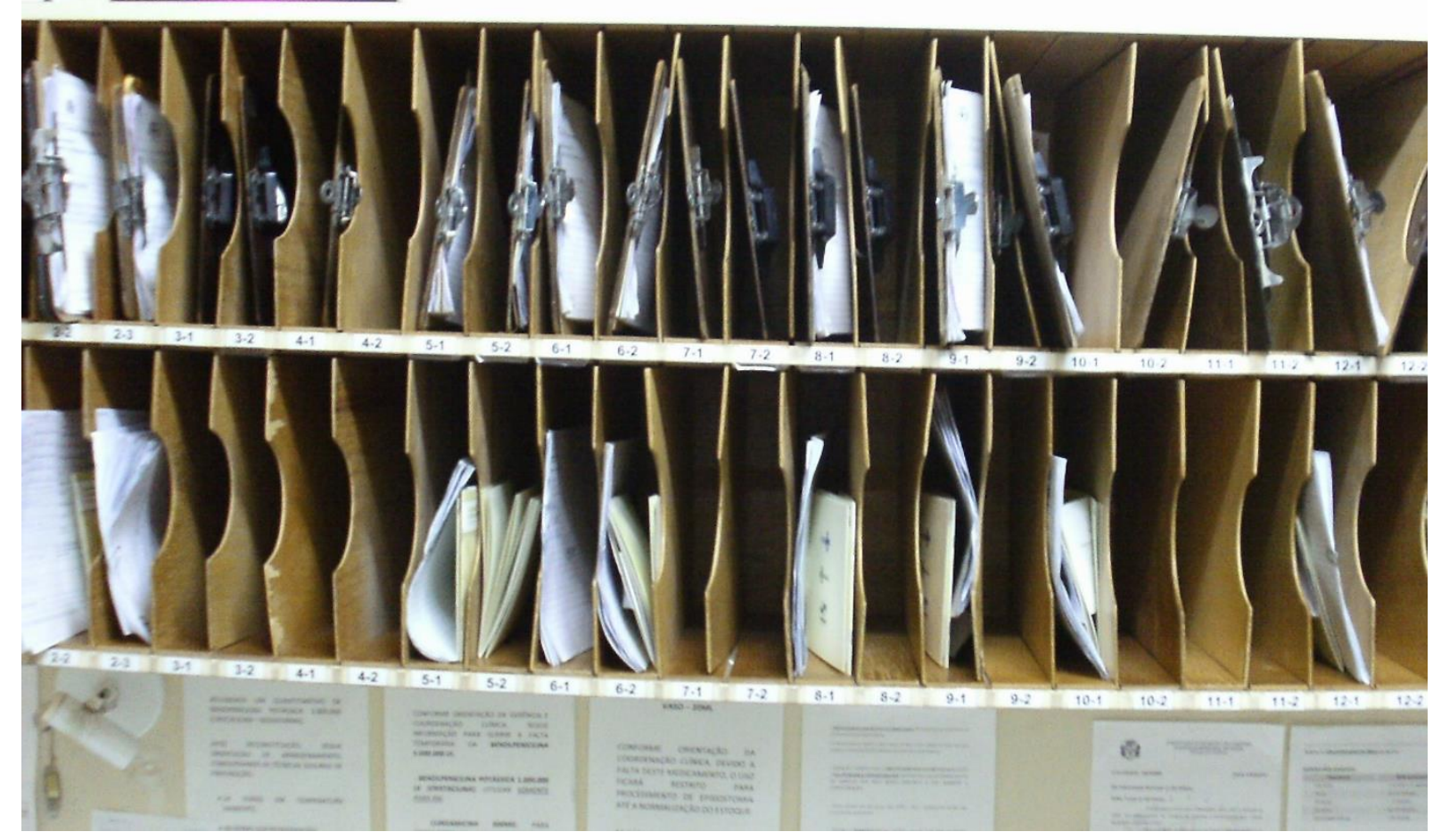

Figura 24 - Fotografia produzida pela Enfermeira Obstétrica Beatriz 


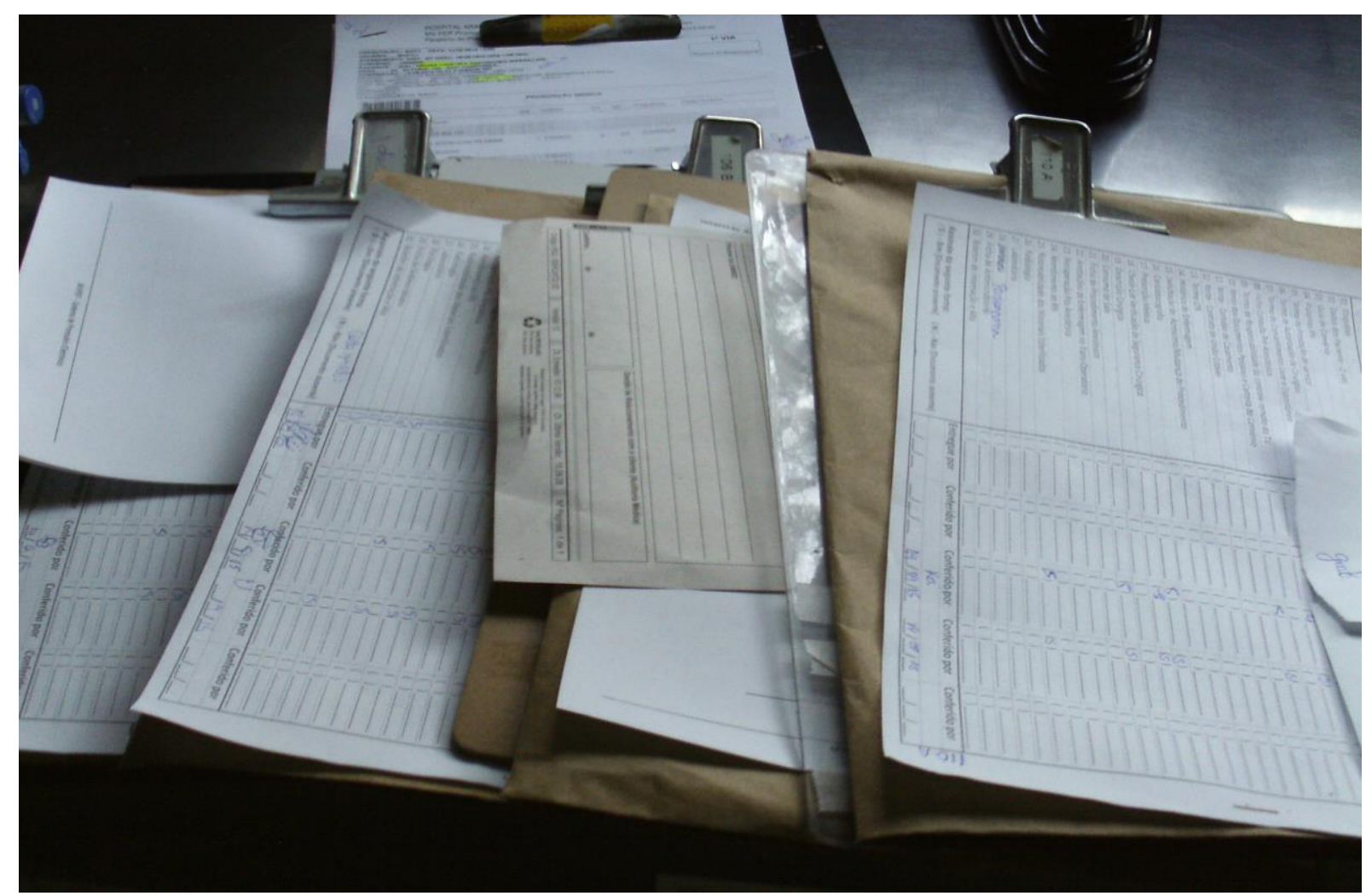

Figura 25 - Fotografia produzida pela Enfermeira Obstétrica Maria

Apesar de instituído desde 2002, o prontuário eletrônico não é uma realidade em todas as maternidades, pois essa adaptação necessita de investimentos em tecnologia, treinamento de pessoas e uma mudança cultural das instituições.

As enfermeiras obstétricas relatam que a burocracia e a falta de informatização do prontuário dificultam o trabalho, de modo que gastam muito tempo da jornada de trabalho arrumando prontuários e preenchendo papéis, tempo este que poderia ser aproveitado junto ao cuidado da paciente e sua família. 
O preenchimento dos papéis dificulta muito, então a gente quer "despachar” os papéis logo para dar atenção à paciente. Isso é o tempo que você perde por não ser informatizado, deixa de dar assistência à paciente e sua família.... (Beatriz).

Se fosse um cadastro eletrônico, facilitaria, mesmo que preenchido manualmente e depois digitalizado... (Rose).

Gastamos muito tempo preenchendo papéis e este tempo poderia ser gasto no cuidado à paciente, a informática facilita a vida... (Maria).

O tempo utilizado para preencher papel é muito elevado, poderíamos utilizá-lo na sala de parto, acompanhando os nascimentos... (Luiza).

Trabalhei em uma instituição onde os processos eram digitais, facilitava o uso racional do tempo e sobrava mais tempo para a assistência em geral, ao cuidado direto com a paciente e sua família... (Gabriela). 


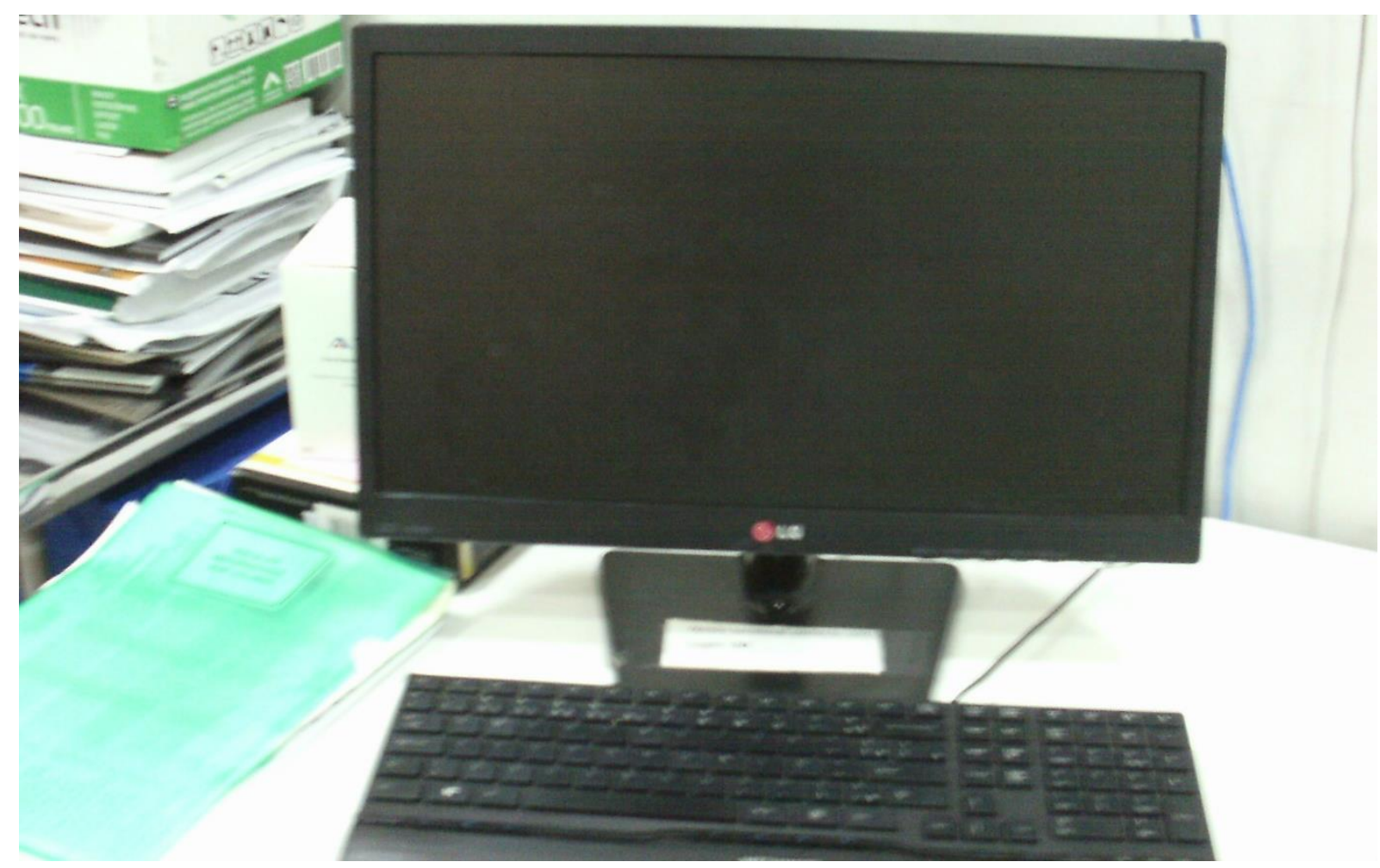

Figura 26 - Fotografia produzida pela Enfermeira Obstétrica Eva

É importante ressaltar que o uso de recursos de tecnologias da informação nas práticas assistenciais agrega valor ao processo de trabalho, auxiliando no ganho em eficiência e na qualidade assistencial (BRASIL, 2014b).

No estudo realizado por Jensen et al. (2016), ficou evidenciado que há necessidade de incentivo à capacitação dos enfermeiros em nosso país, especialmente no que tange à gestão de banco de dados e de informações que norteiam as decisões gerenciais. É importante ressaltar que este conteúdo deve ser agregado às habilidades essenciais de ensino de forma a sustentar a formação dos enfermeiros. Isso contribui para a prática baseada em evidências e da gestão de informação.

Logo, a utilização de ferramentas de informática, sinalizadas nas figuras 26 e 27, devem estar inseridas no ensino e nas práticas iniciais dos futuros enfermeiros, para que 
sejam culturalmente formados para o uso desta tecnologia em proveito de melhoria na assistência prestada e na prática baseada em evidências (ZUIN, 2010).

A internet figura como um sistema que unifica todos os recursos da tecnologia de informação. Consiste em um sistema físico que possibilita a intercomunicação entre computadores por meio de sinais analógicos da rede telefônica. Esses sinais são transmitidos e interpretados na linguagem digital, por um dispositivo de entrada e saída conhecido como modem, presente nos computadores (VELLOSO, 2004).

As tecnologias de informação estão presentes na maioria dos campos da atividade humana, modificando a cultura dos indivíduos com o passar dos tempos, trazendo muitos benefícios para o homem. Várias áreas procuram usufruir delas, utilizando a acessibilidade da informação para melhorias em diversas áreas, inclusive na área da saúde, onde há grandes esforços para obter benefícios e garantir a qualidade na assistência (BALL et al., 1998; MARIN; GRANITOFF, 1998; SANTOS; MARQUES, 2006).

A cultura digital, utilizada como representação da vida social nos dias atuais, tem produzido mudanças estruturais não somente na maneira de transmissão e acesso à cultura, mas propriamente no que diz respeito ao conceito e nas atitudes que possuímos perante a cultura, com implicações políticas determinantes para a formação. A cultura digital assume um caráter crítico e há necessidade de explicitar as ambiguidades resultantes da tensão entre os processos de adaptação a essa nova cultura e as possibilidades de resistência crítica inerentes à vida social (GOMES, 2013).

As redes sociais na internet constituem serviços baseados na web e permitem aos usuários adquirirem um perfil público dentro de um sistema limitado, agregarem outros usuários e compartilharem uma conexão em forma de rede. Desta forma, podem ver e percorrer a própria lista de contatos e serem vistos. A rede social mais conhecida 
e mais popular é o Facebook. Em nosso país estima-se mais de 70 milhões de perfis nesta rede social (MARTORELL et al., 2016).

Assim, com a mudança cultural da internet e o advento das redes sociais, a informatização da saúde trouxe consigo uma fragilidade: o risco de quebra de sigilo de informações, uma vez que, com a popularização da rede, muitos profisssionais utilizam as ferramentas para exporem as rotinas profissionais e dos pacientes sobre seus cuidados, quebrando assim o sigilo e a confidencialidade.

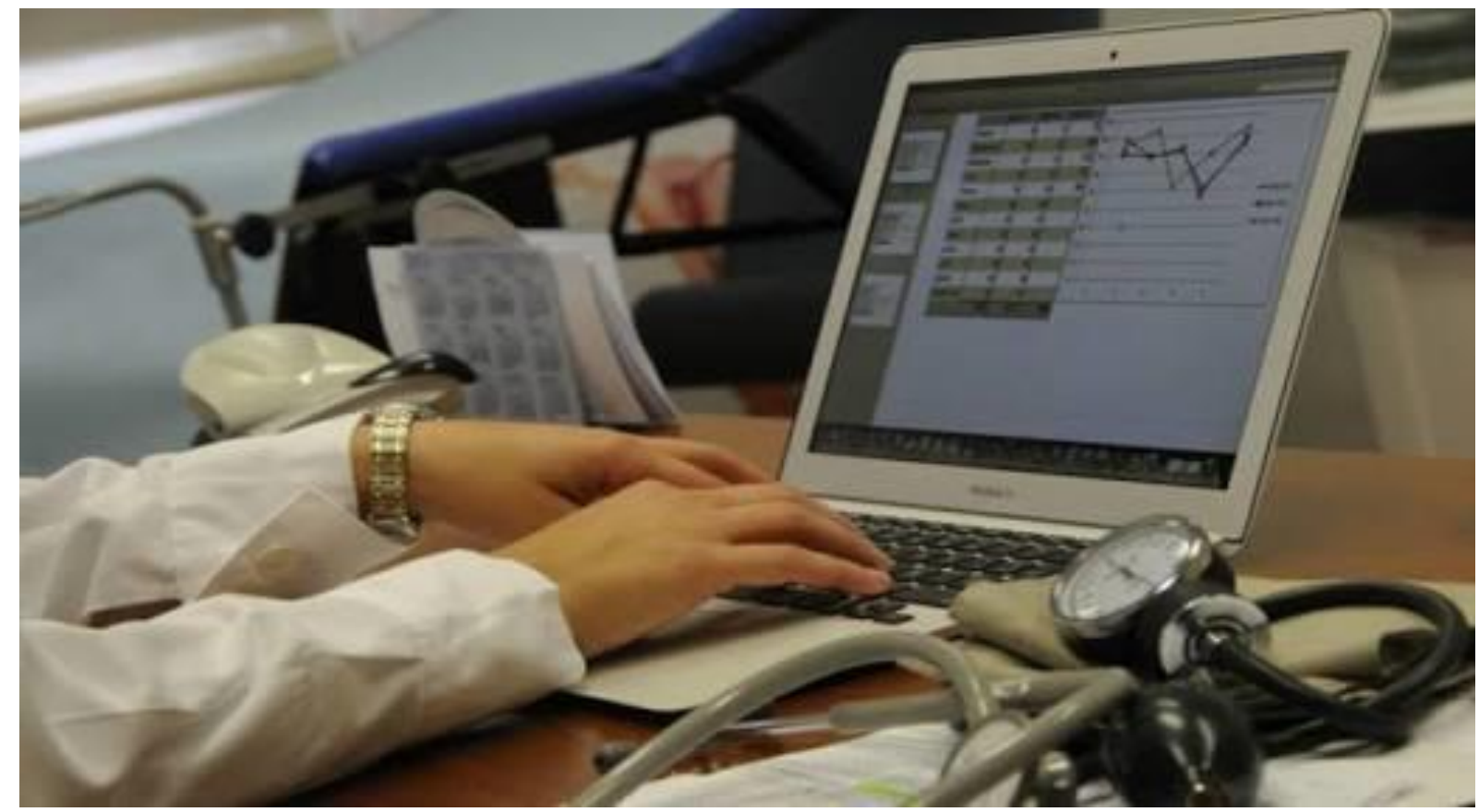

Figura 27- Fotografia produzida pela Enfermeira Obstétrica Gisele ${ }^{8}$

As vezes quando percebemos estamos na internet, na rede social dos pacientes, isso não é bom, expõe a gente como profissional... (Maria).

\footnotetext{
${ }^{8}$ Imagem disponível em $<$ https://es.wikipedia.org/wiki/Historia_cl\%C3\%ADnica $>$. Acesso durante o período de coleta de dados.
} 
A internet deveria ser utilizada como canal de comunicação com nossos pacientes, mostrando nossa qualidade, mas muitas vezes serve de desabafo, nas redes sociais, de forma antiética ... (Lia).

Comentários dos pacientes na internet ficam em evidência ao público, dificultando o acesso e conhecimento da humanização, porque elas têm que entender que o parto normal é fisiológico, natural... (Gabriela).

Outro tema destacado pelas enfermeiras obstétricas como um fator que dificulta a assistência diz respeito à gravidez na adolescência. Todos os anos, aproximadamente 16 milhões de adolescentes entre 15 e 19 anos engravidam, representando em média $11 \%$ dos nascimentos ocorridos mundialmente. Em nosso país, em 2007, os partos em adolescentes representaram 23\% (QUEIROZ et al., 2014; OMS, 2009; PARIZ et al., 2012; COSTA et al., 2013).

A gestação na adolescência é considerada um problema de saúde pública em diversos países, inclusive o nosso, pois as repercussões da gravidez neste período da vida podem ser físicas, emocionais e socioeconômicas (MARTINS et al., 2014; KUDLOWIEZ; KAFROUNI, 2014; OLIVEIRA et al., 2015).

Do mesmo modo que a adolescência, a gestação nesta etapa da vida provoca uma série de mudanças tanto biológicas como psicológicas e sociais. Ademais, constitui uma 
fase de reorganizações na vida da mulher e nos papéis que ela exerce, ocasionando em mudanças intra e interpessoais nela e em sua família (PICCININI et al., 2008, STERN, 1997).

A OMS (2009) sinaliza que a gestação adolescente, tendo como base as complicações fisiológicas, possui mais riscos tanto para mãe quanto para o bebê, pois pode levar a anemia, hipertensão, aborto espontâneo, trabalho de parto prolongado, parto prematuro e morte materna, devido à imaturidade física, emocional e funcional. Isso é destacado em mães que apresentam baixa escolaridade, drogadição, condições socioeconômicas desfavoráveis, desnutrição e seguimento pré-natal ineficaz (CRUGNOLA et al., 2014; ANDRADE et al., 2015; NEVES et al., 2015).

Há forte tendência de esse momento ser transformado em uma turbulência, pois haverá uma sobreposição de tarefas no desenvolvimento da jovem adolescente. Todavia, vários autores mostram que a idade cronológica da mãe pouco pode informar sobre suas reais capacidades de exercer a maternidade, da mesma forma que a maternidade por si só não confere status de adulta à mãe adolescente (BRUCKNER et al., 2004; FLANAGAN et al., 1995; SANTOS et al., 2008).

Neste sentido, Paulo Freire (2011) reitera que é próprio da consciência crítica a sua integração com a realidade, ao contrário da consciência ingênua, que se superpõe imaginariamente a ela, como figura ser o caso das adolescentes, que acreditam ingressar no mundo adulto com a gravidez e assim resolverem seus problemas cotidianos através da maternidade.

Nossa sociedade conceitua a gravidez na adolescência como um evento que repercute obrigatoriamente de maneira negativa na vida da adolescente. Transita no imaginário social de que esta condição está fundamentalmente presente nas famílias com 
poucas condições educacionais, culturais, sociais e econômicas. Na visão das adolescentes, nem sempre a gestação é um problema ou uma consequência indesejada (ESTEVES; MENANDRO, 2005; PARIZ et al., 2012).

Supomos que todos os fatores descritos acima façam com que as enfermeiras obstétricas desse estudo não se sintam preparadas para a diversidade cultural e social e para prestarem os cuidados necessários a essas jovens parturientes, como retrato da figura 28 .

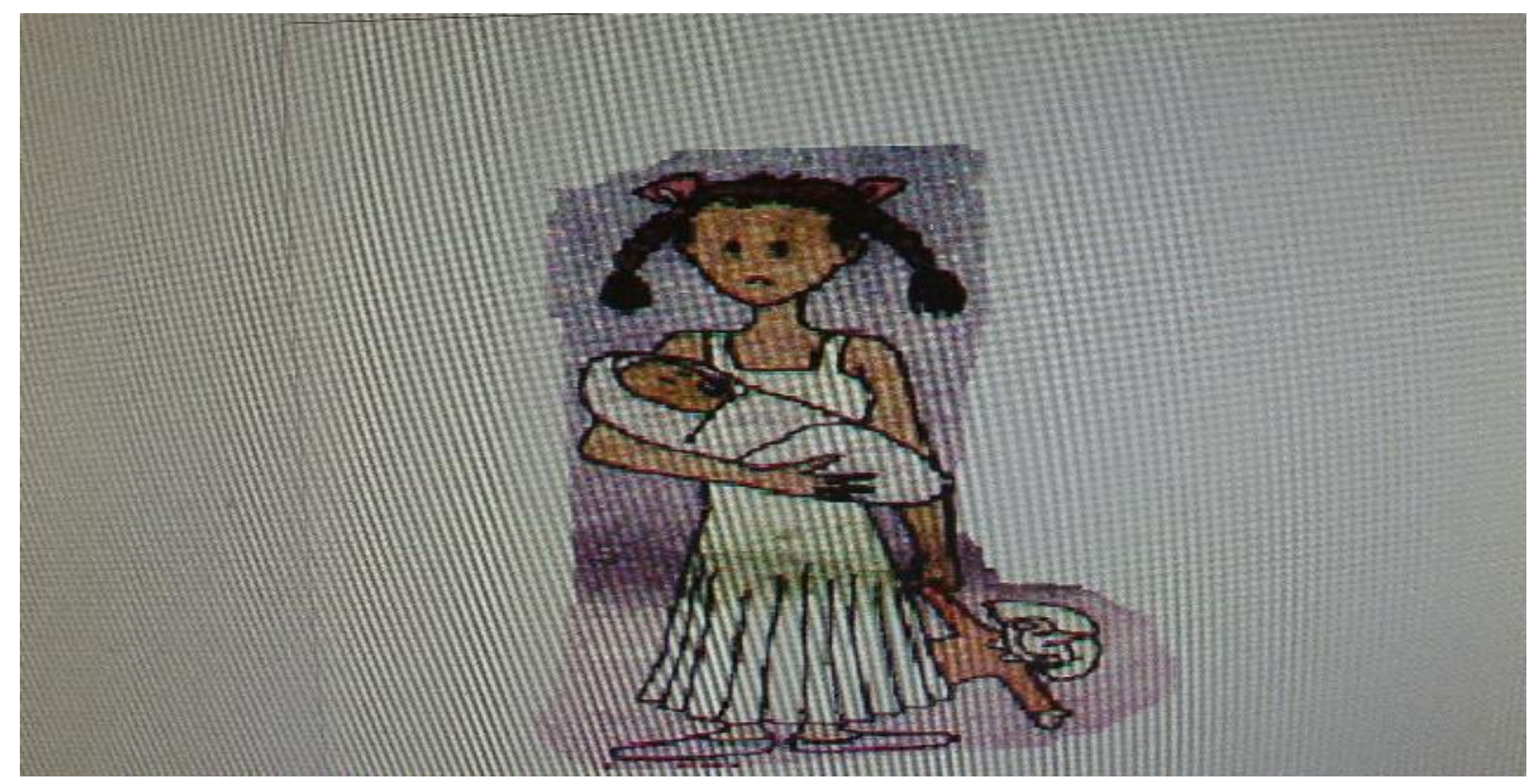

Figura 28 - Fotografia produzida pela Enfermeira Obstétrica Luiza

A gestante adolescente é uma dificuldade pra mim, porque elas não querem ajudar, têm uma resistência, culturalmente deveríamos tratá-las iguais às demais, mas não é assim fácil, é uma fase delicada... (Luiza). 
Depende da estrutura familiar da adolescente, já tivemos casos onde se saem bem, mas na maioria das situações, devido à falta de estrutura domiciliar: pai da criança preso, pai e mãe que não aceitam ou até mesmo a própria adolescente não quer, temos dificuldades... (Clara).

Há também um preconceito da nossa parte sobre a gravidez na adolescência, pela cultura e pela sociedade, muitas vezes uma jovem pode ser mais madura em relação às situações, a uma mulher mais velha, mas no geral elas possuem mais dificuldades... (Beatriz).

É complicado cuidar de pais adolescentes, não possuímos estrutura emocional... (Maria).

O parto é uma experiência humana das mais significativas e enriquecedoras para todos que participam, seja a mulher, a família ou os profissionais envolvidos. Vivemos em nosso país um modelo tecnocrático hegemônico, somos campeões de cesarianas e de institucionalização do parto (MILBRATH et al., 2010; SANFELICE; SHIMO, 2014; BRASIL, 2011a; 2011b; DIAS, 2011; FRANK; PELLOSO, 2013). Em decorrência dessas práticas, aproximadamente $98 \%$ dos nascimentos ocorrem dentro de instituições de saúde, onde as taxas de cesarianas, no sistema público, atingem 52\% enquanto, na saúde suplementar, podem chegar a $80 \%$. Esses dados refletem resultados maternos e perinatais piores que os encontrados em países com igual ou menor índice de desenvolvimento socioeconômico (DIAS, 2011; DATASUS, 2011). 
Em virtude deste cenário, o MS vem, há alguns anos, elaborando e estabelecendo programas e ações de incentivo ao parto normal e à humanização, iniciativas estas que visam retomar o protagonismo da mulher e recuperar os indicadores de saúde. Em relação ao problema da institucionalização do parto, sabe-se que os partos que não acontecem nos estabelecimentos de saúde figuram como urgências ou partos que acontecem de forma abrupta, sem assistência e/ou planejamento de acontecerem no domicílio.

Estudos comprovam que os partos realizados no domicílio, conforme figura 29, são menos intervencionistas, possuem menor risco de mortalidade neonatal e os recémnascidos apresentam índice de Apgar elevado nos primeiros minutos de vida (LINDGREN et al., 2008; ONSEN; JEWELL, 2006; COLACIOPPO et al., 2010).

O parto domiciliar planejado, retratado nas Figuras 29 e 30, é muito pouco realizado na atualidade. Sua prática é cercada de intensas discussões na mídia, nas redes sociais, nos conselhos profissionais de saúde e pela população em geral. A classe médica contemporânea considera o parto domiciliar como um retrocesso frente ao avanço da atualidade, pois creditam a prática a insucesso e risco à saúde da mãe e filho; outrossim, as mulheres que preferem a assistência domiciliar são socialmente reconhecidas como irresponsáveis e voltadas à moda contemporânea (SANFELICE et al., 2014).

Algumas enfermeiras obstétricas são consideradas "peitudas" por realizarem esse trabalho (parto domiciliar), por isso nem todas têm a coragem de realizar... (Clara).

Aqui no Brasil são muitos, fora a questão da locomoção, temos a recepção no hospital que mesmo com o médico do 
grupo de parto presente alguns se recusam a atender a paciente, então é como "dar a cara a tapa”, ainda não temos essa cultura no pais... (Maria).

No parto domiciliar a demora do Samu é elevada, pois se caso precisarmos transportar a paciente ou bebê, após o parto, em situações de risco, não podemos esperar o tempo de atendimento do Samu... (Rose).

A dificuldade é a locomoção mas o fato de realizar o parto em casa, pela presença constante e atuação plena da enfermeira obstétrica, o conforto do nosso lar, não precisar estar em área hospitalar... (Gabriela).

Há uma resistência por parte dos médicos em relação ao parto domiciliar, pois eles estudam e se aprimoram durante anos para trabalhar em ambientes hospitalares $e$ agora os procedimentos estão sendo realizados em casa, como antigamente, e até mesmo pelas próprias enfermeiras... (Carla).

Em São Paulo já fazem muitos partos domiciliares. As pacientes contratam o Serviço de remoção particular, que fica à disposição. Mesmo com a dificuldade de locomoção devido ao trânsito, conseguem ter êxito no socorro Fora ao transporte garantido, temos que ter o "back up" realizado por um médico que vai recepcionar a gestante no ambiente hospitalar uma referência... (Luiza). 


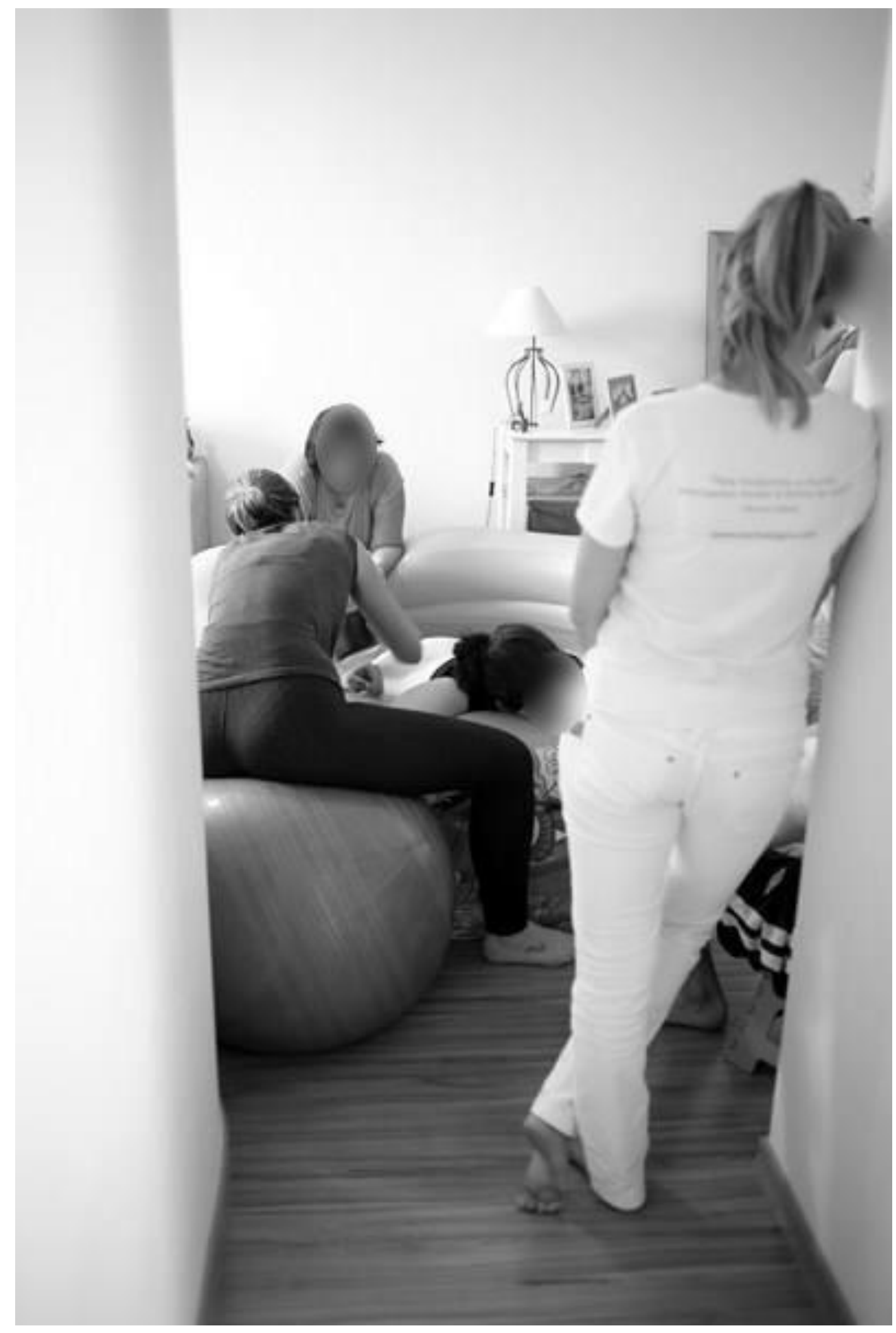

Figura 29- Fotografia produzida pela Enfermeira Obstétrica Rose 


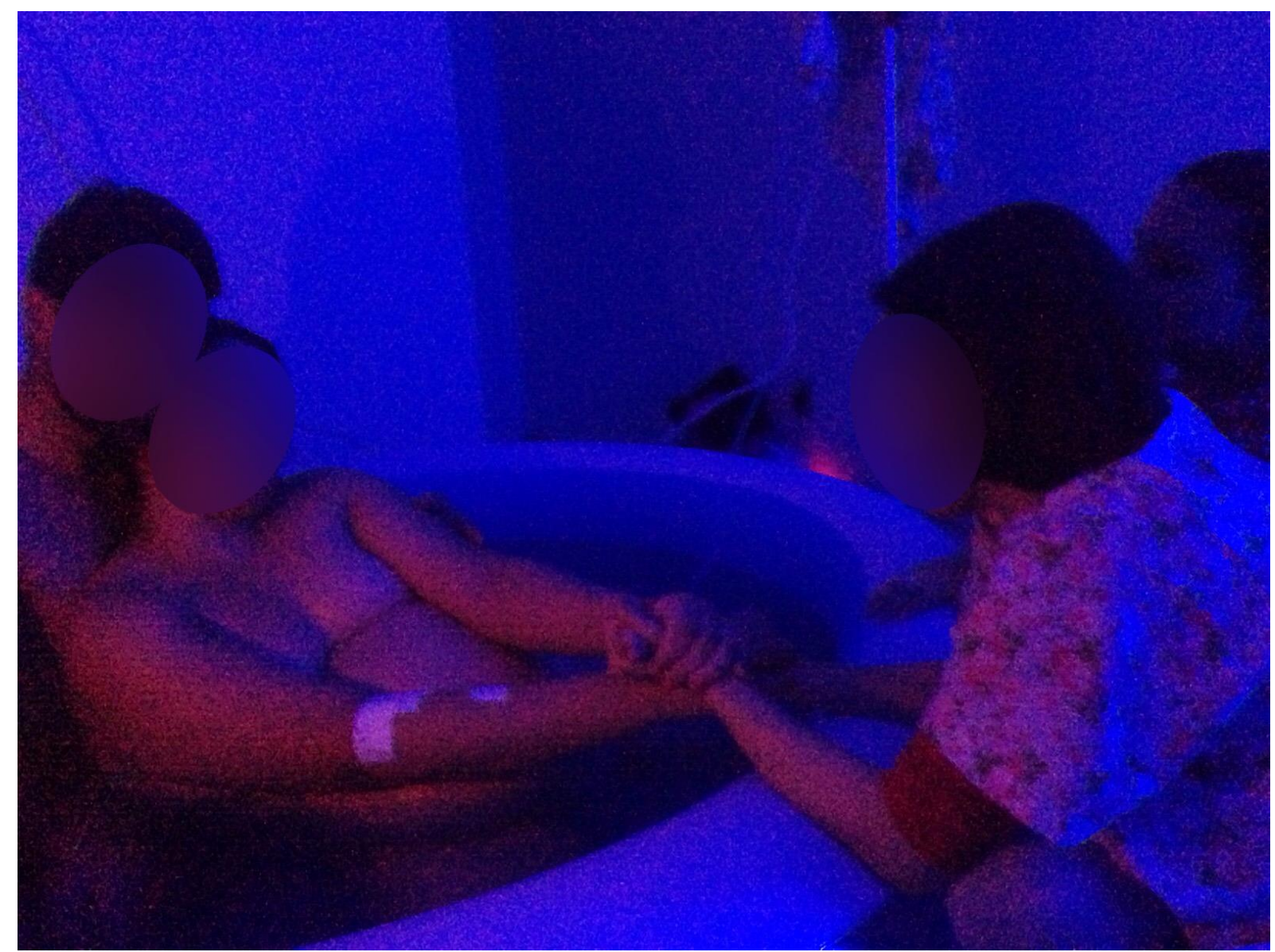

Figura 30 - Fotografia produzida pela Enfermeira Obstétrica Gabriela

Essa recepção é de extrema importância. Aprendemos na pós que, quando entregamos a paciente de parto domiciliar para um médico no hospital, a responsabilidade é dele a partir deste momento, no entanto resistem ao atendimento uma vez que as decisões e procedimentos do parto foram tomadas pelo grupo de parto e não pelos próprios... (Clara).

Para a realização do parto domiciliar tem que ter uma equipe preparada, existe uma falta de aceitação... (Beatriz). 
Um caso mal sucedido já é motivo para críticas por parte dos médicos. Temos uma imensa preocupação... (Maria).

Logo abaixo, a Figura 31 nos reporta ao rompimento de amarras na atuação das enfermeiras obstétricas e, na sequência, os relatos das enfermeiras em relação ao tema autonomia.

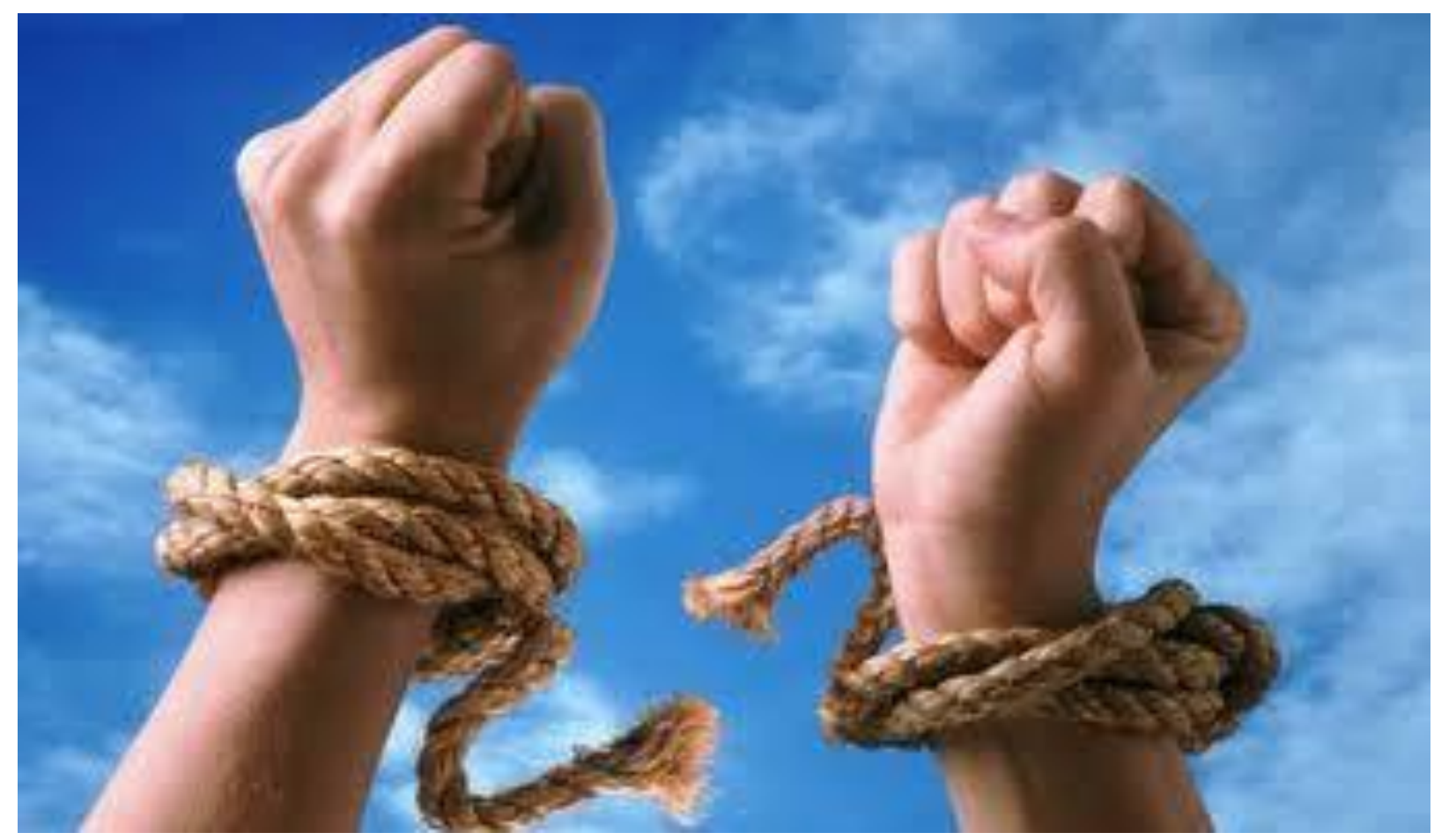

Figura 31 - Fotografia produzida pela Enfermeira Obstétrica Gisele ${ }^{9}$

Algumas instituições tiram totalmente nossa autonomia... (Gabriela).

\footnotetext{
${ }^{9}$ Imagem disponível em < https://spikcompany.ru/free-advice/without-a-mortgage/>. Acesso durante o período de coleta de dados.
} 
$E u$ tenho liberdade pra indicar um procedimento $e$ discutir com o médico o caso. Temos total autonomia. Ultimamente temos muito parto no leito, e agora com um novo projeto teremos só a mesa PPP nos quartos... (Clara).

Depende muito a confiança e tempo de trabalho do funcionário, eu consigo realizar inovações, pois há muitos anos depositam em mim toda responsabilidade do pósparto, isso facilita minha autonomia plena no setor... (Luiza).

Paulo Freire (2011), em Pedagogia da Autonomia, reflete sobre a autonomia de forma a corroborar com os achados desta pesquisa. Assim, Freire define que somos seres indiscutivelmente programados, mas, de modo nenhum, determinados. Somos programados sobretudo para aprender, precisamente, porque nos tornamos capazes de inventar a nossa existência. Fazendo uma análise no que tange ao modelo assistencial adotado na maioria das instituições que assistem mulheres no processo de parturição, pode-se inferir que as enfermeiras obstétricas trabalham em um ambiente programado, ainda assim, são seres humanos e como tal, históricos e não determinados.

Freire (2011) afirma que, para que haja a construção da autonomia, é necessário "estar centrada em experiências estimuladoras da decisão e da responsabilidade, vale dizer, em experiências respeitosas de liberdade". 
Assim, a construção da autonomia das enfermeiras obstétricas está condicionada à liberdade proporcionada pela autoridade do espaço hospitalar, ou seja, a cultura instalada no ambiente hospitalar. A relação de liberdade/autoridade é condição sine qua non para o exercício da autonomia das enfermeiras, mesmo levando em consideração a subjetividade de cada ser humano.

O trabalho de parto, natural e fisiológico, sofre influência de vários fatores, entre eles emocionais, culturais, ambientais e sociais. Este momento, apesar de ser um momento feliz, muitas vezes é marcado pela violência obstétrica, transformando o momento da chegada de um novo membro familiar em um momento traumático, gerando prejuízos físicos e psicológicos (GALLO et al., 2011; BISCEGLI et al., 2015; OLIVEIRA et al., 2001).

A violência obstétrica é conceituada principalmente pela negligência na assistência, discriminação social, violência verbal, física e psicológica. Também devemos considerar um ato de violência o uso inadequado de tecnologias e a realização de procedimentos na mulher durante a gravidez, parto e puerpério sem o seu consentimento informado, infringindo assim sua cultura e sua individualidade. A violência pode ser praticada por diversas pessoas, como pessoas íntimas, estranhas, profissionais, ou pela instituição, resultando assim em uma assistência desumanizada e em ações que podem contribuir para que ocorram complicações ou efeitos indesejáveis à mulher e ao seu filho (BRASIL, 2003; ANDRADE et al., 2016; OMS, 1996; AGUIAR; OLIVEIRA, 2011; MINAYO, 2006; MILFONT et al., 2011).

Vários estudos demonstram o uso arbitrário de autoridade pelos profissionais de saúde sobre o corpo da mulher e sua sexualidade. Em nosso país, uma entre quatro mulheres sofre violência durante o parto e as principais queixas encontradas são 
condutas desrespeitosas realizadas pelos profissionais, atitudes grosseiras, a falta de analgesia e a negligência. A população mais acometida foi a de mulheres pardas (29\%), com 4 ou 5 filhos (29\%), habitantes da região nordeste (27\%) e das capitais (30\%). (AGUIAR; OLIVEIRA, 2011; MILFONT et al., 2011; DOMINGUES et al., 2004; TEIXEIRA; PEREIRA, 2006; VENTURI et al., 2010; BISCEGLI et al., 2015).

O modelo assistencial humanizado preconiza um cenário onde as ações e os procedimentos são realizados com a utilização de conhecimentos científicos e sistematizados, sempre conduzidos para as necessidades individuais da parturiente. Não obstante, também são necessárias melhorias nas instituições no que tange à estrutura física e, principalmente, ao preparo dos profissionais de saúde, cuja atuação deve estar norteada para assistência humanizada e voltada para as diretrizes assistenciais de saúde empregadas em nosso país (BRASIL, 2012a; UNICEF, 2011; RIESCO et al., 2009).

A atuação da enfermeira obstétrica na assistência ao trabalho de parto e parto de baixo risco pode melhorar a assistência prestada, reduzindo procedimentos desnecessários, pois ela oferece um cuidado integral à mulher e sua família. Conforme OMS e o MS, a enfermagem obstétrica é a categoria profissional mais preparada para a mudança no histórico brasileiro e mais capacitada para prestar uma assistência segura no processo de parto e nascimento (CARVALHO et al., 2010; BRASIL, 2012b, OMS, 1996; SILVA et al., 2014).

Durante a discussão realizada em grupo, as enfermeiras obstétricas relataram presenciar a persistência de práticas não recomendadas por evidências científicas nas maternidades onde atuam, como representada na Figura 32 e nos discursos relacionados abaixo. 


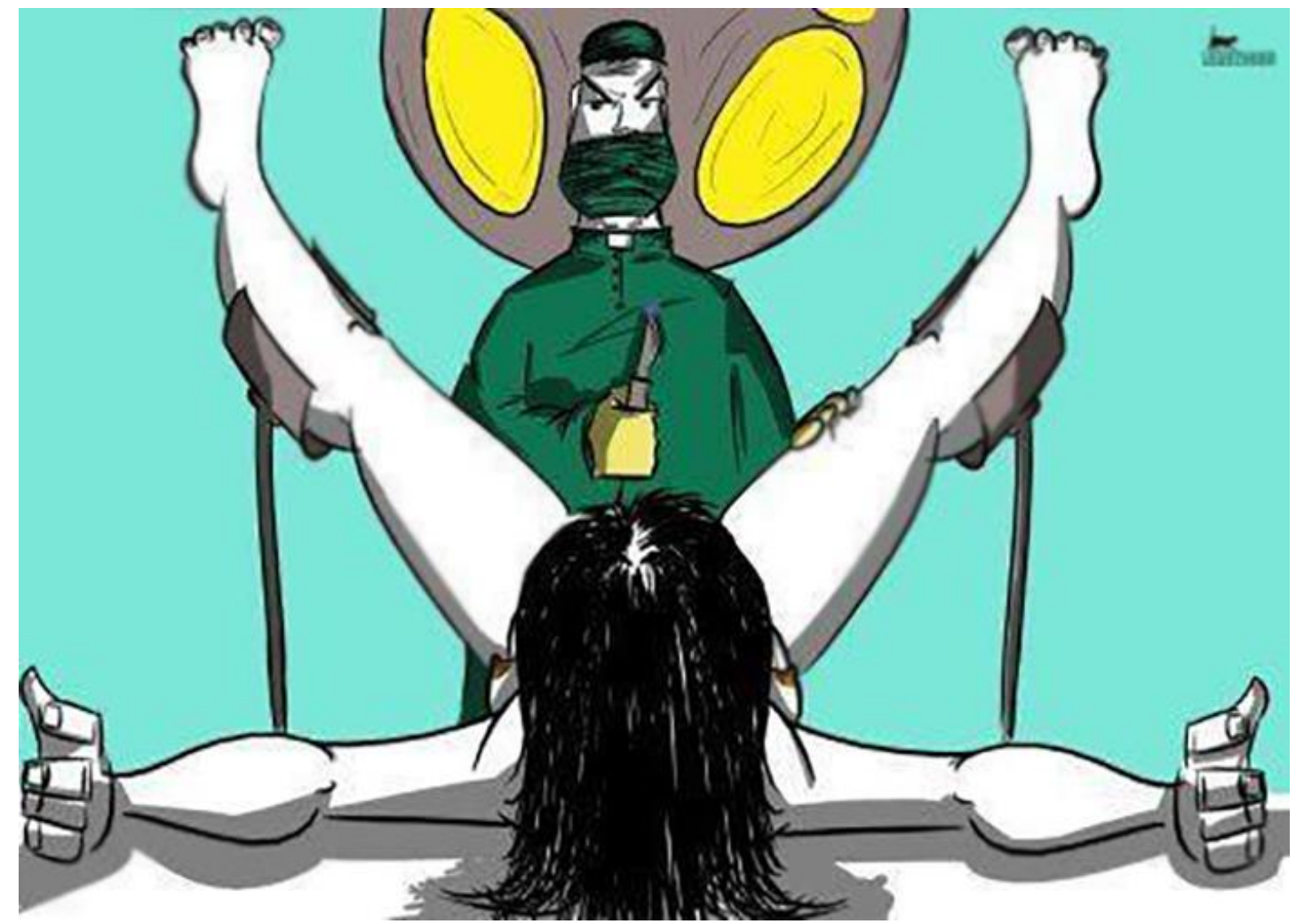

Figura 32 - Fotografia produzida pela Enfermeira Obstétrica Gabriela ${ }^{10}$

Quando é o residente da medicina que está na sala de parto eu nem entro, pois já ouvi eles falando que fazem epsiotomia pra aprender, acho isso um absurdo. Ainda vemos esse tipo de comportamento, é uma violência contra a mulher e sua família... (Clara).

Frases do tipo "na hora de fazer não gritou" ainda permeiam a sala de parto... (Carolina).

\footnotetext{
${ }^{10}$ Imagem disponível em < http://epoca.globo.com/vida/noticia/2015/07/violencia-obstetrica-1-em-cada-4brasileiras-diz-ter-sofrido-abuso-no-parto.html>. Acesso durante o período de coleta de dados.
} 
Eu acredito que antes era bem pior, epsio, forceps $e$ kristeller eram procedimentos normais em um parto, visão diferente, mas ainda presencio a violência obstétrica, falas agressivas e imposição.... (Beatriz).

Já tive situações onde eu mesmo fui agredida, ao acompanhar uma paciente durante o trabalho de parto, no hospital, agressão verbal é desmoralizante... (Clara).

O duro é presenciar procedimentos que não terão benefícios algum, somente são realizados para aprender, tipo a episiotomia, várias vezes já ouvi profissionais dizendo que fazem para ensinar, não porque realmente precisa... (Rose).

O número de toques vaginais é extremamente alto, não há necessidade de realizar de hora em hora, somente fazem para ensinar...e a mulher como fica?... (Maria).

Neste sentido, ao adotarem práticas não validadas cientificamente para o atendimento ao trabalho de parto, parto e nascimento, os profissionais de saúde e as instituições realizam ações e procedimentos que podem repercutir negativamente sobre os resultados perinatais. A violência obstétrica contra a mulher constitui um problema de estado, pois é a infração mais frequente dos direitos humanos e constitui um problema de saúde pública, que gera altos custos econômicos e sociais (TERÁN et al., 2013; PEREIRA et al., 2015). 
Controlar a violência obstétrica constitui-se um desafio para a saúde pública, na medida em que, muitas vezes, a violência é invisível e não reconhecido como afronta aos direitos humanos (LANSKY et al., 2014).

Finalizando a análise dos dados coletados por meio das entrevistas individuais e em grupo, podemos constatar que alguns temas estiveram presentes com repetição nos dois momentos da pesquisa, a saber: a necessidade de aprimoramento continuado por parte das enfermeiras, a autonomia necessária mas muitas vezes reprimida, a assistência humanizada mas muitas vezes violentada, a precária infraestrutura.

Todavia, durante este estudo ficou sinalizado o quanto a cultura não é apartada da prática da enfermeira obstétrica, por ser inseparável da condição humana. Percebeu-se pelos relatos das enfermeiras que foi possível interpretar a cultura em que estas profissionais estão inseridas, sendo, ao mesmo tempo, produto e produtoras, sujeitos e assujeitadas, agentes ativos e passivos da cultura local. 
CONSIDERAÇÕES FINAIS 


\section{CONSIDERAÇÕES FINAIS}

Este estudo possibilitou compreender a vivência da enfermeira obstétrica no cenário da admissão, pré-parto, parto e pós-parto imediato e interpretar os aspectos facilitadores e dificultadores de sua atuação nos serviços de atenção materna, pela participação intensa das enfermeiras obstétricas no processo de investigação, favorecido pela utilização da antropologia interpretativa, que delineou a análise necessária para a compreensão deste evento social.

A situação encontrada é a de marginalização da assistência obstétrica. Em quase todas as instituições prevalece ainda o modelo biomédico, concentrado em intervenções e com poucas ações de humanização. Mesmo quando as enfermeiras obstétricas estão inseridas na assistência, elas encontram obstáculos para o desenvolvimento de sua prática assistencial, tanto pela equipe multiprofissional em que estão inseridas quanto pelas organizações em que atuam.

Com base nas considerações orais produzidas individualmente pelas enfermeiras obstétricas, foi possível identificar o significado do trabalho da enfermeira obstétrica nos cenários da admissão, pré-parto, parto e pós-parto imediato. Os resultados evidenciaram que o significado da atuação sofre influência da cultura das organizações e das equipes profissionais, sendo assim categorizado mediante três vias: acolhimento e vínculo, autonomia e sentimentos aflorados no ambiente de trabalho. 
Foi possível observar que o acolhimento é o principal significado atribuído, traduzido como o momento de transmitir tranquilidade e desmistificar o cuidado. Esta aproximação foi apontada como o passo inicial e fundamental para a criação do vínculo, momento de levar segurança e apoio para a paciente e sua família, uma vez que este momento é marcado por medos e incertezas decorrentes da mudança do cenário do pré-natal e o surgimento do cenário do parto e nascimento.

Neste sentido, as atitudes e ações originadas no acolhimento estão relacionadas à mudança de cultura das organizações, pois vivemos uma realidade em que o parto foi institucionalizado, mudando a cultura das mulheres de parir no domicílio e adentrando nas maternidades, um local cheio de intervenções e procedimentos.

A autonomia surgiu como um fator incapacitante, levando à implicação de qualidade na assistência prestada pelas profissionais, mesmo com todo respaldo legal que possuem profissionalmente e de políticas públicas que favorecem a sua atuação profissional. Muitas relatam ainda a submissão à classe médica, margilizando desta forma a especialidade e o exercício profissional delas. Como muitas instituições adotam o modelo biomédico, a submissão das enfermeiras obstétricas a esta classe profissional ficou evidente nos relatos.

Por outro lado, mesmo frente a um quadro de condições desfavoráveis, percebeu-se autonomia em algumas profissionais, conquistada pelo conhecimento sobre o assunto, cultura das instituições e iniciativa das enfermeiras. Ainda carecemos de estudos mais aprofundados para a melhor compreensão desta temática e o desenvolvimento de ações de empoderamento das profissionais para melhoria nos indicadores de saúde materno e fetal.

A assistência prestada pelas enfermeiras obstétricas é carregada de emoções, pois atuam em contato direto, de forma completa e holística. Logo, a alegria do nascimento e 
a responsabilidade gerada por suas ações foram entendidas como natural, energizante, como um sentimento de preocupar-se com alguém e se importar com a mulher.

Torna-se importante o desenvolvimento de pesquisas voltadas para desvelar os sentimentos das enfermeiras obstétricas envolvidas no cenário da admissão, pré-parto, parto e pós-parto imediato. Por mais que atuamos em um cenário globalizado, inovador e informatizado, o ser humano continua sendo atravessado por sentimentos e emoções, constituindo a subjetividade de cada indivíduo.

Diante dos resultados obtidos por esta pesquisa, tanto nos momentos individuais quanto grupais e nas fotografias produzidas, foi possível apontar alguns aspectos sinalizados como potencializadores e de fragilidades da assistência obstétrica, a saber:

- Estabelecimento do planejamento familiar facilita a atuação das enfermeiras obstétricas visto que possibilita à mulher e sua família a compreensão de todo curso gestacional, desde a concepção até o momento da admissão, pré-parto, parto e pósparto imediato;

- Humanização da assistência ao parto no que tange ao cuidado centrado e individualizado nas necessidades da mulher é um fator facilitador, de forma a proporcionar o acolhimento, a satisfação e o bem-estar do binômio. Também é relevante sinalizar que a adoção de práticas e ações pouco intervencionistas e centradas em evidências científicas foi apontada como facilidades. A presença de um acompanhante, escolhido pela parturiente, ficou evidenciado com um fator que agrega valores positivos à assistência obstétrica e ao resultado final do processo. Ficou também demonstrado a importância do papel da doula como facilitadora no acompanhamento do pré-parto e nascimento, pois são treinadas para promoverem conforto físico e emocional às parturientes; 
- O trabalho em equipe foi traduzido como primordial para o estabelecimento da assistência por favorecer o crescimento de todos os membros da equipe de saúde; cada um pode contribuir para o grupo com conhecimentos cognitivos e culturais acrescidos de habilidades individuais;

- A educação contínua e permanente foi realçada como um fator de aptidão para prestarem uma assistência mais segura e humanizada, pois, além da necessidade de estarem sempre alinhadas com a ciência, as enfermeiras obstétricas devem transmitir seus conhecimentos com treinamentos ministrados à equipe de que participam. Desta forma atuam como potencializador da assistência;

- A autonomia representa tanto um fator potencializador como uma fragilidade na realidade da enfermeira obstétrica. Está dentro das competências da formação como enfermeiro e traduz a individualidade de cada profissional; assim, cada pessoa age de forma individual e única. Logo, ao se depararem com um modelo culturalmente biomédico, as enfermeiras obstétricas devem atuar com habilidade, conhecimento e iniciativa para desenvolverem ações de modo a garantir a sua atuação;

- A infraestrutura foi indicada como um fator que facilita a assistência da enfermeira obstétrica para atuação de acordo com as novas políticas e diretrizes do MS de nosso país, porém, à medida que não foi implantada em todas as instituições, figura como uma fragilidade;

- A falta de realização de partos nas maternidades onde atuam foi mencionada como um fator de fragilidade, por não se sentirem seguras, visto que realizaram poucos partos nos programas de especialização;

- A assistência pré-natal ineficaz foi apontada como um fator que dificulta a atuação da enfermeira obstétrica, pois a realidade assistencial é marcada por atendimento de 
gestantes com o número de consultas abaixo do recomendado, ou não iniciado, mau preenchimento da carteirinha da gestante, não realização de exames, o que acarreta aumento do risco gestacional e prejudica a qualidade da assistência prestada no momento da admissão para o nascimento;

- A ausência do contato precoce mãe e recém-nascido foi assinalado como uma fragilidade, pois nem sempre esta prática está na cultura das instituições. Desta forma não conseguem proporcionar o vínculo necessário entre o binômio, evidenciado por vários estudos científicos e pelas políticas públicas vigentes;

- A falta de informatização nos setores foi apontada como uma fragilidade. As enfermeiras obstétricas salientaram que o trabalho está muito burocrático e o tempo consumido com prontuários faz falta para a atuação nos cuidados, o que é extremamente prejudicial para a assistência e os resultados de qualidade decorrentes dela. Outro ponto relevante levantado é que, na atualidade, o uso das redes sociais deixa expostas as rotinas de trabalho e de pacientes, podendo haver quebra de sigilo e confidencialidade;

- A gravidez na adolescência foi destacada como um momento de fragilidade visto que as enfermeiras obstétricas revelaram que não se sentem preparadas cultural e socialmente para prestarem os cuidados necessários à jovem mãe.

- O estabelecimento do parto no domicílio ainda está distante da realidade assistencial da maioria dos sujeitos desta pesquisa e, desta forma, atua como um fator que dificulta a assistência, porque é uma modalidade assistencial estimulada pelas políticas públicas brasileiras, mas, na realidade, as enfermeiras enfrentam muitas barreiras para sua implantação; 
- A violência obstétrica surgiu como um fator dificultador da atuação das enfermeiras obstétricas, pois ainda atuam em um cenário onde prevalece a realização de práticas não recomendadas por evidências científicas, repercutindo negativamente na qualidade assistencial prestada por elas.

Os resultados assim apontaram para uma realidade que indica como a cultura está presente na atuação no cenário da admissão, pré-parto, parto e pós-parto imediato. Durante todo o estudo foi possível constatar a presença da cultura, tanto por parte das parturientes, das enfermeiras obstétrica, no ambiente de trabalho e nas políticas públicas de saúde e educação.

As enfermeiras obstétricas são profissionais capacitadas para atuarem na humanização da assistência e contribuírem para a redução de índices de morbimortalidade materna em nosso país. Assim, os achados deste estudo podem fomentar ações e mudanças nas organizações de saúde.

Por conseguinte, as experiências vivenciadas pelas enfermeiras obstétricas no cotidiano das maternidades, a valorização de sua maneira de agir e pensar, os aspectos de fragilidades e potencialidades vivenciados no exercício de sua profissão, no reconhecimento de seu grupo social e pela cultura pessoal e das instituições, devem ser vistos como fatores que poderão servir de base para ações comunitárias e sociais na intenção de trocar experiências, incentivar grupos e aprimorar a assistência prestada.

Do mesmo modo como Geertz (2006) tentava interpretar os espaços que pesquisou sem se deixar influenciar por conhecimentos e determinismos previamente definidos para melhor compreender a cultura local, também me arrisquei, como pesquisadora deste estudo, a entender, por meio das entrevistas, do grupo focal e nas fotos produzidas pelos 
sujeitos da pesquisa, a cultura presente no espaço de atuação das enfermeiras na prática diária no pré-parto, parto e pós-parto. Espero que os achados desse estudo possam contribuir para fomentar mudanças nas organizações de saúde. 
REFERÊNCIAS 


\section{REFERÊNCIAS}

AGUIAR,, J. M.; OLIVEIRA, A. F. P. L. Violência institucional em maternidades públicas sob a ótica das usuárias. Interface, Botucatu, v. 15, n. 36, p. 79-92, Mar. 2011.

ALMEIDA, E. A.; MARTINS FILHO, J. O contato precoce mãe-filho e sua contribuição para o sucesso do aleitamento materno. Rev. Ciênc. Méd. Campinas, v. 13, n. 4, p. 381-388, Out./Dez. 2004.

ALMEIDA, N. A. M; MEDEIROS, M; SOUZA, M. R. Perspectivas de dor do trabalho de parto normal de primigestas no período pré-natal. Texto contexto - enferm. Florianópolis, v. 21, n. 4, p. 819-827, Out./Dez. 2012.

ALVES, C. N. et al. Cuidado pré-natal e cultura: uma interface na atuação da enfermagem. Esc. Anna Nery, Rio de Janeiro, v. 19, n. 2, p. 265-271, Jun. 2015.

ALVES, D. A. et al. Prontuário eletrônico em cenário de prática: percepção dos graduandos e profissionais de fonoaudiologia. Rev. CEFAC., São Paulo, v. 18, n. 2, p. 385-391, Mar./Abr, 2016.

AMORIM, T.; GUALDA, D. M. R. Coadjuvantes das mudanças no contexto do ensino e da prática da enfermagem obstétrica. Rev. Rene, Fortaleza, v. 12, n. 4, p. 833-840, Out./Dez. 2011.

ANDRADE, P. O. N. et al. Fatores associados à violência obstétrica na assistência ao parto vaginal em uma maternidade de alta complexidade em Recife, Pernambuco. Rev. Bras.

Saúde Mater. Infant., Recife, v. 16, n. 1, p. 29-37, Mar.2016.

ANDRADE, P. R. et al. Enfrentando uma experiência difícil mesmo com apoio: a adolescente menor vivenciando a maternagem. Rev. Gaúcha Enferm., Porto Alegre, v. 36, n. spe, p. 111$118,2015$.

ANDREUCCI, C. B.; CECATTI, J. G. Desempenho de indicadores de processo do Programa de Humanização do Pré-natal e Nascimento do Brasil: uma revisão sistemática. Cad. Saúde Pública, Rio de Janeiro, v. 27, n. 6, p. 1053-1064, Jun. 2011.

BALL, M. J. et al. Integrating nursing and informatics. In: Nursing informatics: were caring and technology meet. New York: Springer-Verlag, 1998. p. 11-17.

BARBIERI, M. et al. Banho quente de aspersão, exercícios perineais com bola suíça e dor no trabalho de parto. Acta paul. enferm., São Paulo, v. 26, n. 5, p. 478-484, 2013.

BARDIN L. Análise de conteúdo. Lisboa: Edições 70, 2009.

BARROS, L. M.; SILVA, R. M. Atuação da enfermeira na assistência à mulher no processo de parturição. Texto contexto - enferm. Florianópolis, v. 13, n. 3, p. 369-375, jul./set. 2004. 
BARROS, L. M.; SILVA, R. M.; MOURA, E. R. F. Autonomía de la enfermera que asiste el parto normal en Brasil. Universidad de Antiquia. Facultad de Enfermería. Investigación y Educacion en Enfermería, Medellin, v. XXV, n. 12, Set. 2007.

BARROS, M.E., LIMA, L.H., OLIVEIRA, E.K. Assistência pré-natal no município de Quixadá: um estudo descritivo. Online Braz J Nurs. v.11, n. 2, p. 319-30, Ago. 2012. Disponível em: <http:// www.objnursing.uff.br/index.php/nursing/article/view/3782/ pdf_1. Acesso em: 12 Abr. 2016.

BASILE FILHO A. Equipes dão certo. 2011. Disponível em: <http://www.institutojetro.com/Artigos/gestao_de_pessoas/equipes_dao_certo.html>. Acesso em 20 Jul. 2016.

BASSO, C. G.; NEVES, E. T.; SILVEIRA, A. Associação entre a realização de pré-natal e morbidade neonatal. Texto Contexto Enferm, Florianópolis; v. 21, n. 2, p. 269-76, Abr./Jun. 2012.

BEECKMAN, K. et al. The relationship between antenatal care and preterm birth: the importance of content of care. Eur. Journal Public Health, v. 23, n. 3, p. 366-371, Jun. 2013.

BERLINGUER, G. A ética em saúde. São Paulo: Hucitec, 1996. 136p.

BERNI, N. I. Assistência de Enfermagem à cliente obstétrica: a busca do significado. Rev. Gaúcha Enferm. Porto Alegre, v. 15, n. 1/2, p. 13-19, 1994.

BEZERRA, S. M. Prontuário eletrônico do paciente: uma ferramenta para aprimorar a qualidade dos serviços de saúde. Meta: Avaliação, Rio de Janeiro, v. 1, n. 1, p. 73-82, Jan./Abr. 2009.

BISCEGLI, T. S. et al. Violência Obstétrica: perfil assistencial de uma maternidade escola do interior do Estado de São Paulo. CuidArte Enferm., Catanduva, v. 9, n. 1, p. 18-25, Jan./Jun. 2015.

BOCCOLINI, C. S. et al. Factors associated with breastfeeding in the first hour of life. Rev. Saúde Pública, São Paulo, v. 45, n. 1, p. 69-78, Fev. 2011.

BOCK, A. M. B.; FURTADO, O.; TEIXEIRA, M. L. T. Psicologias: uma introdução ao estudo de psicologia. 14 ed. São Paulo: Saraiva, 2008.

BOWLBY, J. Cuidados maternos e saúde mental. São Paulo: Martins Fontes, 2006.

BRASIL. Lei no 7.498 de 25 de junho de 1986. Dispõe sobre o exercício da Enfermagem e dá outras providências. Diário Oficial da União, Brasília, 26 de junho de 1986. Seção 1, p. 273. 
Decreto $n^{\circ} 94.406$ de 8 de junho de 1987. Regulamenta a Lei $n^{\circ} 7.498$, de 25 de junho de 1986, que dispõe sobre o exercício da enfermagem, e dá outras providências. Diário Oficial da União. Brasília, 9 de junho de 1987. Seção 1, p. 8853.

Ministério da Saúde. Portaria n 2.815 de 29 de maio de 1998. Inclui a Tabela do Sistema de Informações Hospitalares do Sistema Único de Saúde (SIH/SUS) o Grupo de Procedimento já incorporados aos valores o fator de recomposição de $25 \%$ previsto na PT/MS/GM 2.277/95. Diário Oficial da União. Brasília, 2 de junho de 1998. Seção 1, p. 103.

Ministério da Saúde. Portaria n. 985/GM, de 05 de agosto de 1999a. Dispõe sobre a Criação do Centro de Parto Normal-CPN, no âmbito do Sistema Único de Saúde/SUS, para $\mathrm{o}$ atendimento à mulher no período gravídico-puerperal. Disponível em <http://www.saude.gov.br/atosnormativos>. Acesso em: 22 Fev. 2014.

Ministério da Saúde. Portaria no 1.406 de 15 de dezembro de 1999b. Aprova o Regulamento do Prêmio Nacional Prof. Galba de Araújo. Ministério da Saúde. Brasília: 1999. Disponível em: <sna.saude.gov.br/legisla/legisla/informes/GM_P1.406_99informes.doc〉. Acesso em 12 Abr. 2015.

Ministério da Saúde. Secretaria de Políticas de Saúde. Área Técnica de Saúde da Mulher. Parto, aborto e puerpério: assistência humanizada à mulher. Brasília: Ministério da Saúde, 2001.

Ministério da Saúde. Secretaria de Políticas de Saúde. Área Técnica de Saúde da Mulher. Assistência em Planejamento Familiar: manual técnico. $4^{\mathrm{a}}$ ed. Brasília: Ministério da Saúde, 2002a.

Ministério da Saúde. Secretaria de Assistência à Saúde. Humanização do parto: humanização no pré-natal e nascimento. Brasília: Ministério da Saúde, 2002 b.

Lei n. 10.778/2003 de 24 de novembro de 2003. Estabelece a notificação compulsória, no território nacional, do caso de violência contra a mulher que for atendida em serviços de saúde públicos ou privados. Diário Oficial da União, Brasília, 25 de novembro de 2003. Seção I, p. 11.

. Lei 11.108 de 07 de abril de 2005. Altera a Lei no 8.080, de 19 de setembro de 1990, para garantir às parturientes o direito à presença de acompanhante durante o trabalho de parto, parto e pós-parto imediato, no âmbito do Sistema Único de Saúde - SUS. Diário Oficial da União, Brasília, 08 de abril de 2005. Seção 1, p. 1.

Ministério da Saúde. Secretaria de Atenção à Saúde. Área Técnica de Saúde da Mulher. Pré-natal e Puerpério: atenção qualificada e humanizada - manual técnico. Brasília: Ministério da Saúde, 2006.

. Ministério da Saúde. ANVISA. Resolução nº 36 de junho 2008. Diário Oficial da União, Brasília, 3 de junho de 2008. Seção 1, p. 53. 
Ministério da Saúde. Secretaria de Vigilância em Saúde. Saúde Brasil 2009: uma análise da situação de saúde e da agenda nacional e internacional de prioridades em saúde. Brasília: Ministério da Saúde, 2010a. Disponível em <http://bvsms.saude.gov.br/bvs/publicacoes/saude_brasil_2009.pdf>. Acesso em: 25 Fev. 2012.

Ministério da Saúde. Secretaria de Atenção à Saúde. Núcleo Técnico da Política Nacional de Humanização. Acolhimento nas práticas de produção de saúde. $2^{\mathrm{a}}$ ed. Brasília: Ministério da Saúde, 2010b.

. Ministério da Saúde. Portaria no 1459 de 24 de Junho de 2011. Institui no âmbito do SUS a Rede Cegonha. Diário Oficial da União, Brasília, 27 de junho de 2011. Seção 1, p. 109. 2011a.

. Ministério da Saúde. Portaria $\mathrm{n}^{\mathrm{o}} 2351$ de 05 de Outubro de 2011. Altera a Portaria $\mathrm{n}^{\mathrm{o}}$ 1459/GM/MS, de 24 de junho de 2011, que institui no SUS a Rede Cegonha. Diário Oficial da União, Brasília, 6 de outubro de 2011. Seção 1, p. 58, 2011 b.

Ministério da Saúde. Edital no 21, de 5 de setembro de 2012. Processo seletivo destinado à oferta de bolsas para o Programa Nacional de Residência em Enfermagem Obstétrica (PRONAENF). Diário Oficial da União, Brasília, 6 de setembro de 2012a. Seção 3, p. 136.

Ministério da Saúde. Secretaria de Vigilância em Saúde. Departamento de Análise de Situação de Saúde. Saúde Brasil 2011: uma análise da situação de saúde e a vigilância da saúde da mulher. Brasília: Ministério da Saúde, 2012b. 444 p.

Ministério da Saúde. Secretaria de Atenção à Saúde. Departamento de Atenção Básica. Atenção ao pré-natal de baixo risco. Brasília: Ministério da Saúde, 2012c.

Conselho Nacional de Saúde. Resolução n 466, de 12 de dezembro de 2012. Aprova normas regulamentadoras de pesquisas envolvendo seres humanos. Diário Oficial da União. Brasília, 2013a.

Ministério da Saúde. Portaria $\mathrm{n}^{\circ}$ 904, de 29 de maio de 2013. Estabelece diretrizes para a implantação e habilitação de Centro de Parto Normal (CPN), no âmbito do Sistema Único de Saúde (SUS), para o atendimento à mulher e ao recém-nascido no momento do parto e do nascimento, em conformidade com o Componente Parto e Nascimento da Rede Cegonha. Diário Oficial da União, Brasília, 31 de maio de 2013b. Seção 1, p. 68.

Ministério da Saúde. Universidade do Ceará. Humanização do parto e nascimento. Caderno Humaniza SUS, v. 4, Brasília: Ministério da Saúde, 2014a.

Ministério da Saúde. Porque GESITI? Gestão de Sistemas e Tecnologias da Informação em Hospitais: panorama, tendências e perspectivas em saúde. Brasilia: Ministério da Saúde, 2014b. 
BRUCKNER, H.; MARTIN, A.; BEARMAN, P. S. Ambivalence and pregnancy: Adolescent's atitudes, contraceptive use and pregnancy. Perspectives on Sexual and Reproductive Health, v. 36, n. 6, p. 248-257, Nov./Dec. 2004.

BRUGGEMANN, O. M.; OSIS, M. J. D.; PARPINELLI, M. A. Apoio no nascimento: percepções de profissionais e acompanhantes escolhidos pela mulher. Rev. Saúde Pública, São Paulo, v. 41, n. 1, p. 44-52, Fev. 2007.

CAMPBELL, D. A.; LAKE, M. F.; BACKSTRAND Jr. A ramdomized control trial of continuous support in labor by a Lay Doula. J Obstet Gynecol Neonatl Nurs. v. 35, n. 4, p. 456-464, 2006.

CARLINI-COTRIM. B. Potencialidades da técnica qualitativa: grupo focal em investigações sobre abuso de substâncias. Rev. Saúde Pública, São Paulo, v.30, n. 3, p. 3-15, 1996.

CARRARO, T. E. et al. O papel da equipe de saúde no cuidado e conforto no trabalho de parto. J. res.: fundam. Care. online, Rio de Janeiro, v. 5, n. 4, p. 743-754, Out/Dez, 2013.

CARVALHO, C. C. M. et al. Episiotomia seletiva: avanços baseados em evidências. Femina, Rio de Janeiro, v.38, n. 5, p. 265-270, Maio, 2010.

CARVALHO, C. G. Importância da inteligência emocional para a efetiva (ação) de uma assistência de enfermagem humanizada. Rev. Universidade Vale do Rio Verde, Betim, v. 10, n. 1, p. 630-638, 2013.

CATALANI, C., MINKLER, M. Photovoice: a review of the literature in health and public health. Health Education Behav. 2009. 20(9), 1-28.

CHAGAS, N. R.; MONTEIRO, A. R. M. A relação entre a mãe adolescente e o bebê prétermo: sentimentos desvelados. Rev. Gaúcha Enferm. Porto Alegre, v. 28, n. 1, p. 35-44, 2007.

CHECHIN, P. L. Reflexões sobre o resgate do parto natural na era da tecnologia. Rev. Brasileira Enferm. Brasília, v. 55, n. 4, p. 444-448, 2002.

CLUETT, E. R., BURNS, E. Immersion in water in labour and birth. Cochrane Database of Systematic Reviews 2009, Issue 2. Disponível em:

<http://onlinelibrary.wiley.com/doi/10.1002/14651858.CD000111.pub3/abstract;jsessionid=9 EDD72B8C2089236D06E54DA2F72A957.f04t03>. Acesso em: 10 Jul. 2016.

COLACIOPPO, P. M. et al. Parto domiciliar planejado: resultados maternos e neonatais. Rev. Enfermagem, Coimbra, v. 2, n. 3, p. 81-90, Dec. 2010. 
CONSELHO FEDERAL DE ENFERMAGEM. Resolução no 478 de 14 de abril de 2015. Normatiza a atuação e a responsabilidade civil do Enfermeiro Obstetra e Obstetriz nos Centros de Parto Normal e/ou Casas de Parto e dá outras providências. Disponível em: $<$ http://www.cofen.gov.br/resolucao-cofen-no-04782015_30969.html>. Acesso em: 25 Jun. 2016

CONSELHO FEDERAL DE ENFERMAGEM. Resolução n 516/2016. Normatiza a atuação e a responsabilidade do Enfermeiro, Enfermeiro Obstetra e Obstetriz na assistência às gestantes, parturientes, puérperas e recém-nascidos nos Serviços de Obstetrícia, Centros de Parto Normal e/ou Casas de Parto e outros locais onde ocorra essa assistência; estabelece critérios para registro de títulos de Enfermeiro Obstetra e Obstetriz no âmbito do Sistema Cofen/Conselhos Regionais de Enfermagem, e dá outras providências. Disponível em: <http://www.cofen.gov.br/resolucao-cofen-no-05162016_41989.html>. Acesso em: 25 Jun. 2016.

CONSELHO FEDERAL DE MEDICINA - CFM. Resolução do CFM nº 1638, de 10 de julho de 2002. Define prontuário médico e torna obrigatória a criação da comissão de prontuário nas instituições de saúde. Diário Oficial da União, Brasília, 9 de agosto de 2002, Seção I. p.184.

CONSELHO NACIONAL DE EDUCAÇÃO. Câmara de Educação Superior. Resolução $\mathrm{CNE} / \mathrm{CES} \mathrm{n}^{\circ} 3$ de 7 de novembro de 2001. Institui Diretrizes Curriculares Nacionais do Curso de Graduação em Enfermagem. Diário Oficial da União, Brasília, 9 de novembro de 2001. Seção I. p.37.

CONSELHO REGIONAL DE MEDICINA DO RIO DE JANEIRO - CREMERJ. Parto em casa: resoluções publicadas no Diário Oficial. Brasil. 19 de Julho de 2012. Disponível em: <http://www.cremerj.org.br/informes/mostra.php?id=1328>. Acesso em: 20 Ago. 2012.

CORTES, C. et al. Metodologia de implementação de práticas baseadas em evidências científicas na assistência ao parto normal: estudo piloto. Rev. Esc. Enferm. USP, São Paulo, v. 49, n. 5, p. 716-725, 2015.

COSTA, A. C.; FARIA, L. A inteligência emocional no contexto da enfermagem: estudo exploratório com o questionário de competências emocional (QCE). In: Atas do X Congresso Internacional Galego-Português. Braga. Universidade do Minho, 2009.

COSTA, C. C. et al. Gestantes adolescentes precoces e tardias e resultados neonatais: estudo de coorte. Online braz. j. nurs. (online), São Paulo, v. 12, n. 4, p. 773-781, Dez. 2013.

COSTA, F. J. L. S. et al. Avaliação da assistência pré-natal na perspectiva da integralidade. J. res.: fundam. Care. online, Rio de Janeiro, v. 8, n. 2, p. 4563-4586, Abr/Jun. 2016.

COUTINHO, T. et al. Monitoramento do processo de assistência pré-natal entre as usuárias do Sistema único de Saúde em município do Sudeste brasileiro. Rev. Bras. Ginecol. Obstet., Rio de Janeiro, v. 32, n. 11, p. 563-569, Nov. 2010. 
CRUGNOLA, C. R. et al. Motherhood in adolescente mothers: maternal attachment, motherinfanto styles of interaction and emotion regulation at three months. Infant Behav Dev. v. 37 , n. 1, p. 44-56, Fev. 2014.

CRUZ, D. S. C.; SUMAM, N. S.; SPINDOLA, T. Os cuidados imediatos prestados ao recémnascido e a promoção do vínculo mãe-bebê. Rev. esc. enferm. USP, São Paulo, v. 41, n. 4, p. 690-697, Dez. 2007.

DATASUS. Consolidação do SINASC 2011. Disponível em: $<$ http://tabnet.datasus.gov.br/cgi/sinasc/Consolida_Sinasc_2011.pdf $>$. Acesso em: 21 Abr 2016.

DAVIM, R. M. B. et al. Banho de chuveiro como estratégia não farmacológica no alívio da dor de parturientes. Rev. Eletr. Enf. [Internet], v.10, n. 3, p. 600-609, 2008. Disponível em: <http://www.fen.ufg.br/revista/v10/n3/pdf/v10n3a06.pdf>. Acesso em: 14 Mar. 2016.

DAVIS-FLOYD, R. The technocratic, humanistic and holistic paradigms of childbirth. International Journal of Ginecology Obstetrics, v.75, n.1, p.S5-S23, Nov. 2001.

DENZIN, N. K.; LINCOLN, Y. S. - Handbook of qualitative research. London, Sage Publication, 1994. 643p.

DIAS, M. A. B. Humanização do parto: política pública, comportamento organizacional e ethos profissional. Cad. Saúde Pública, Rio de Janeiro, v. 27, n. 5, p. 1042-1043, Maio, 2011.

DIAS, M. A. B.; DOMINGUES, R. M. S. M. Desafios na implantação de uma política de humanização da assistência hospitalar ao parto. Ciênc. saúde coletiva, Rio de Janeiro, v. 10, n. 3, p. 669-705, Set. 2005.

DODOU, H. D. et al. A contribuição do acompanhante para a humanização do parto e nascimento: percepções de puérperas. Esc. Anna Nery, Rio de Janeiro, v. 18, n. 2, p. 262 269, Jun. 2014.

DOMINGUES, R. M. S. M.; SANTOS, E. M.;LEAL, M. C. Aspectos das satisfações das mulheres com assistência ao parto: contribuição para um debate. Cad. Saúde Pública, Rio de Janeiro, v. 20, supl. 1, p. S52-S62, 2004.

DONABEDIAN, A. La calidad de la atención médica: definición y métodos de evaluación. La Prensa Médica Mexicana. Mexico, 1991, p. 194.

EAGLETON, Terry. A ideia de cultura. São Paulo: Editora Unesp, 2011.

ENKIN, M. Guia para atenção efetiva na gravidez e parto. 3.ed. Rio de Janeiro: Guanabara Koogan, 2005. 
ESTEVES, J. R.; MENANDRO, P. R. M. Trajetórias de vida: repercussões da maternidade adolescente na biografia das mulheres que viveram tal experiência. Estud. psicol. Natal, v. 10, n. 3, p. 363-370, Dez. 2005.

FLANAGAN, P. J. et al. Adolescent development and transitions to motherhood. Pediatrics, v. 96, n. 2, p. 273-277, 1995.

FLICK, U. Introdução à pesquisa qualitativa. Porto Alegre: Artmed, 2009.

FONTANELLA, B. J. B.; RICAS, J.; TURATO, E. R. Amostragem por saturação em pesquisas qualitativas em saúde: contribuições teóricas. Cad. Saúde Pública, Rio de Janeiro, v. 24, n. 1, p. 17-27, Jan. 2008.

FRANK, T. C.; PELLOSO, S. M. A percepção dos profissionais sobre a assistência ao parto domiciliar planejado. Rev. Gaúcha Enferm., Porto Alegre, v. 34, n. 1, p. 22-29, 2013.

FREIRE, P. Pedagogia do Oprimido. 17 ed. Rio de Janeiro: Paz e Terra. 1987.

FREIRE, P. Pedagogia da autonomia: saberes necessários à prática educativa. 43.ed. São Paulo: Paz e Terra, 2011. 144p.

FRELLO, A. T.; CARRARO, T. E. Componentes do cuidado de enfermagem no processo de parto. Rev. Eletr. Enf. [Internet], v. 12, n. 4, p. 660-668, Out./Dez. 2010. Disponível em: <https://www.fen.ufg.br/fen_revista/v12/n4/v12n4a10.htm>. Acesso em: 20 Jun. 2015.

FUCKS, I. S. A sala de parto: o contato pele a pele e as ações para o estímulo ao vínculo entre mãe-bebê. Av Enferm. v. 33, n.1, p. 29-37, 2015.

FUJITA, J. A. L. M.; SHIMO, A. K. K. Parto humanizado: experiências no Sistema Único de Saúde. Rev. Min. Enferm., Belo Horizonte, v.18, n. 4, p. 1011-1015, Out./Dez. 2014.

FUNDO DAS NAÇÕES UNIDAS PARA A INFÂNCIA - UNICEF. Situação mundial da infância. 2011. Disponível em: 〈http://www.unicef.org/brazil/pt/br_sowcr11web.pdf >. Acesso em: 10 Jan 2016.

GABRIEL, C. S. et al. Qualidade na assistência de enfermagem hospitalar: visão de alunos de graduação. Rev Gaúcha de Enferm. Porto Alegre, v. 31, n. 3, p. 529-35, 2010.

GALLO, R. B. S. et al. Recursos não-farmacológicos no trabalho de parto: protocolo assistencial. Femina, São Paulo, v. 39, n. 1, p. 41-48, Jan. 2011.

GASTALDO, D. M.; MEYER, D. E. A formação da enfermeira: ênfase na conduta em detrimento do conhecimento. Rev. bras. enferm., Brasília, v. 42, n. 1-4, p. 7-13, Dez. 1989.

GEERTZ, C. Nova luz sobre antropologia. Rio de Janeiro. RJ: Zahar, 2001. 248p.

GEERTZ, C. O saber local: novos ensaios em antropologia interpretativa. 8.ed. Petrópolis. RJ: Vozes, 2006. 366p. 
GEERTZ, C. A interpretação das culturas. Rio de Janeiro. RJ: LTC, 2014. 323p.

GOLEMAN, D. Inteligência emocional: A teoria revolucionária que redefine o que é ser inteligente. Rio de Janeiro: Objetiva, 1995. 370p.

GOMES, L. R. Cultura digital e formação: implicações políticas do movimento de expansão EAD no Brasil. Impulso, Piracicaba, v. 23, n. 57, p. 29-39, 2013.

GOMES, M. P. Antropologia: ciência do homem: filosofia da cultura. São Paulo: Contexto, 2010.

GUALDA, D. M. R.; MERIGHI, M. A. B.; OLIVEIRA, S. M. J. V. Abordagens Qualitativas: sua contribuição para a enfermagem. Rev. Esc. Enferm. USP, São Paulo, v. 29, n.3, p. 279209, 1995.

GUALDA, D. M. R. A experiência, o significado e a realidade da enfermeira obstetra: um estudo de caso. 1998. (Tese Livre docência) - Escola de Enfermagem, Universidade de São Paulo, São Paulo.

HAGUETTE, T. M. F. Metodologias qualitativas na sociologia. 8 ed. Petrópolis, RJ: Vozes, 2001.

HISLOP, J.; ARBER, S. Understanding women's sleep management: beyond medicalizationhealthicization? Sociol. Health Illn., Oxford, v.25, n.7, p.815-837, Nov. 2003.

HODNETT, E. D. et al. Continuous support for women during childbirth. Cochrane Database of Systematic Reviews, Hoboken, v. 16, n. 2, p. 1-113, 2013.

HODNETT, E. D. Effect on birth outcomes of a formalised approach to care in hospital labour assessment units: international, randomised controlled trial. BMJ, v. 337; a1021, 2008.

INSTITUTO BRASILEIRO DE GEOGRAFIA E ESTATÍSTICA - IBGE. Censo populacional 2010. Disponível em:

<http://cidades.ibge.gov.br/xtras/perfil.php?codmun=411370>. Acesso em 28 Set. 2013.

JENSEN, R.; GUEDES, E. S.; LEITE, M. M. J. Competências em informática essenciais à tomada de decisão no gerenciamento em enfermagem. Rev. Esc. Enferm. USP, São Paulo, v. 50, n. 1, p. 109-117, Fev. 2016.

JORGE, D. R. Evolução da legislação federal do ensino e do exercício profissional da obstetriz (parteira) no Brasil. 1975, 148p. (Tese Livre-docência) - Escola de Enfermagem Ana Nery, Universidade Federal do Rio de Janeiro, Rio de Janeiro, RJ.

KHAN, K. S. et al. Analysis of causes of maternal death: a systematic review. The Lancet, v. 367, n. 9516, p. 1066-1074, 2006. 
KUDLOWIEZ, S.; KAFROUNI, R. Gravidez na adolescência e construção de um projeto de vida. Psico, Porto Alegre, v. 45, n. 2, p. 228-238, Abr./Jun. 2014.

LANSKY, S. et al. Pesquisa Nascer no Brasil: perfil da mortalidade neonatal e avaliação da assistência à gestante e ao recém-nascido. Cad. Saúde Pública, Rio de Janeiro, v. 30, supl. 1, p. S192-S207, 2014.

LAPLANTINE, F. Aprender Antropologia. 12.ed. São Paulo: Brasiliense, 2000.

LEAL, M. C.; GAMA, S. G. N. Nascer no Brasil. Inquérito nacional sobre parto e nascimento. Sumário Executivo Temático da Pesquisa. Fiocruz. 2014.

LEMOS, R. C. A. et al. Visão dos enfermeiros sobre a assistência holística ao cliente hospitalizado. Rev. Eletr. Enf., v. 12, n. 2, p. 354-9, 2010.

LEMOS, R. C. A.; ROSSI, L.A. O significado cultural atribuído ao centro de terapia por clientes e seus familiares: um elo entre a beira do abismo e a liberdade. Rev. Latino-Am. Enfermagem, Ribeirão Preto, v.10, n.3, p. 345-57, Jun. 2002.

LEPPERT, P. C. The challenges and opportunities of proving maternity care through collaborative practice. In: Women's Health, v. 7, n. 5, p. 309-342, 1997.

LIMA, G. P. V. et al. Expectativas, motivações e percepções das enfermeiras sobre a especialização em enfermagem obstétrica na modalidade residência. Esc. Anna Nery, v. 19, n. 4, p. 593-599, Out/Dez, 2015.

LINDGREN, H. E. et al. Transfers in planned home births related to midwife availability and continuity: a Nationwide population-based study. Birth. v. 35, n. 1, p. 9-15, Mar. 2008.

LONDRINA. Prefeitura Municipal. Secretaria Municipal de Saúde. Conselho Municipal de saúde. Relatório de gestão 2008. Disponível em:

http://saude.londrina.pr.gov.br/relatorios_gestao/downloads_site_relatoriosgestao/relatorio_ge stao_2008.pdf>. Acesso em 21 Ago. 2012.

LONDRINA. Prefeitura Municipal. Secretaria Municipal de Saúde. Conselho Municipal de saúde. Relatório de gestão 2010. Disponível em: <http://saude.londrina.pr.gov.br/ relatorios_gestao/downloads_site_relatoriosgestao/relatorio_gestao_2010.pdf>. Acesso em 22Aago. 2012.

LÜDKE, M.; ANDRÉ, M. Pesquisa em educação: abordagens qualitativas. São Paulo: EPU, 1986.

LUFTMAN, J. N.; LEWIS, P. R.; OLDACH, S. H. Transforming the enterprise: the alignment of business and information technology strategies. IBM Systems J., v. 32, n. 1, p. 198-221, 1993.

MACHADO, E.G.C. Gestação, parto e maternidade: uma visão holística. 2.ed. Belo Horizonte: Aurora, 1998. 
MACHADO, N. X. S.; PRAÇA, N. S. Centro de parto normal e assistência obstétrica centrada nas necessidades da parturiente. Rev. esc. enferm. USP, São Paulo, v. 40, n. 2, p. 274-279, Jun. 2006.

MAFETONI, R. R.; SHINO, A. K. K. Efeitos da acupressão na evolução do parto e taxa de cesárea: ensaio clínico randomizado. Rev. Saúde Pública, São Paulo, v. 49, p. 1-9, Jan, 2015.

MAGLUTA, C. et al. Estrutura de maternidades do Sistema Único de Saúde do Rio de Janeiro: desafio à qualidade do cuidado à saúde. Rev. Bras. Saúde Mater. Infant., Recife, v. 9, n. 3, p. 319-329, Set, 2009.

MALAREWICZ, A. et al. The influence of water immersion on the course of first step of parturition in primiparous women. Med Wieku Rozwoj., v. 9, n. 4, p. 773-780, 2005.

MALDONADO, M.T. Psicologia da gravidez: Parto e puerpério. 12a ed. Petrópolis, RJ: Vozes, 1997. 163p.

MAMEDE, F. V., ESSER, M. A. M. Photovoice: uma proposta para pesquisa qualitativa. In: LACERDA, M. R.; COSTENARO, R. G. S. Metodologias da pesquisa para enfermagem e saúde. Porto Alegre-RS: Moriá Editora, 2016, 511p.

MARIN, H.F.; GRANITOFF, N. Informática em enfermagem: uma experiência. Acta paul. enferm., São Paulo, v. 11, n. esp., p. 42-45, 1998.

MARQUES, J. Descartes e sua concepção de homem. São Paulo: Edições Loyola, 1993. $223 p$.

MARTINELLI, K. G. et al. Adequação do processo de assistência pré-natal segundo critérios do Programa de Humanização do Pré-Natal e Nascimento e Rede Cegonha. Rev. Bras.

Ginecol. Obstet., Rio de Janeiro, v. 36, n. 2, p. 56-64, Fev. 2014.

MARTINS, L. W. F.; FRIZZO, G. B.; DIEHL, A. M. P. A constelação da maternidade na gestação adolescente: um estudo de casos. Psicologia USP, São Paulo, v. 25, n. 3, p. 294-306, Dez, 2014.

MARTORELL, L. B.; NASCIMENTO, W. F.; GARRAFA, V. Redes sociais, privacidade, confidencialidade e ética: a exposição de imagens de pacientes no facebook. Interface, Botucatu, v. 20, n. 56, p. 13-23, 2016.

MATOS, T. A. et al. Contato precoce pele a pele entre mãe e filho: significado para mães e contribuições para enfermagem. Rev Bras Enferm., Brasília, v. 63, n. 6, p. 998-1004, Nov./Dez. 2010.

MERIGHI, M. A. B. Trajetória professional das enfermeiras obstétricas egressas da Escola de Enfermagem da Universidade de São Paulo: um enfoque da fenomenologia social. Rev.

Latino-Am. Enfermagem, Ribeirão Preto, v. 10, n. 5, p. 644-653, Out. 2002. 
MILBRATH, V. M. et al. Vivências maternas sobre a assistência recebida no processo de parturição. Esc. Anna Nery, Rio de Janeiro, v. 14, n. 2, p. 462-467, Set. 2010.

MILFONT, P. M. S. et al. Estudo exploratório sobre a implementação de diretrizes para um parto seguro e satisfação das mulheres. Online braz. j. nurs. (online), São Paulo, v. 10, n. 3, Set./Dez. 2011.

MINAYO, M. C. S. O desafio do conhecimento: pesquisa qualitativa em saúde. São Paulo: HUCITEC, 2006.

MONTICELLI, M. et al. Especialização em enfermagem obstétrica: percepções de egressos quanto ao exercício profissional e satisfação na especialidade. Texto Contexto Enferm. Florianópolis, v. 17, n. 3, p. 482-491, Set. 2008.

MORIM, E. A religação dos saberes: o desafio do século XXI. 7. ed. Rio de Janeiro: Bertrand Brasil, 2001. 588p.

NAKANO, A. M. S. et al. O suporte durante o processo de parturição: a visão do acompanhante. Acta paul. enferm., São Paulo, v. 20, n. 2, p. 131-137, Jun. 2007.

NARCHI, N. Z. Atenção pré-natal por enfermeiros na zona leste da cidade de São Paulo Brasil. Rev. esc. enferm. USP, São Paulo, v. 44, n. 2, p. 266-73, Jun. 2010.

NARCHI, N.; CRUZ, E. F.; GONÇALVES, R. O papel das obstetrizes e enfermeiras obstetras na promoção da maternidade segura no Brasil. Ciênc. saúde coletiva, Rio de Janeiro, v. 18, n. 4, p. 1059-1068, Abr. 2013.

NASCIMENTO, E. M. et al. Estudo de fatores de risco para óbitos de menores de um ano mediante compartilhamento de banco de dados. Cad. Saúde Pública, v. 24, n. 11, p. 2593 602, Nov. 2008.

NAVARRO, A. S. S.; GUIMARÃES, R. L. S.; GARANHANI, M. L. Trabalho em equipe: o significado atribuído por profissionais da estratégia de saúde da família. Rev. Min. Enferm., Belo Horizonte, v. 17, n. 1, p. 61-68, Jan./Mar. 2013.

NEVES, A. M. et al. Práticas educativas com gestantes adolescentes visando a promoção, proteção e prevenção em saúde. Revista Mineira de Enfermagem. v. 19(1), p. 241-244, 2015.

ODENT, M. O camponês e a parteira: uma alternativa à industrialização da agricultura e do parto. Tradução de Sarah Bailey. São Paulo: Ground, 2003.

OLIVEIRA, M. E.; BRUGGEMANN, O. M.; Zampieri, M. F. M. A melodia da humanização: reflexões sobre o cuidado no processo do nascimento. Florianópolis: Cidade Futura, 2001. 142p. 
OLIVEIRA, M. P. et al. Cuidado às adolescentes grávidas: perspectiva e atuação de agentes comunitários de saúde. Rev. Enfer. UERJ., Rio de Janeiro, v. 23, n. 1, p. 76-81, Jan./Fev. 2015.

ONSEN, O.; JEWELL, D. Home versus hospital birth. Cochrane Database of Systematic Reviews, n. 2, 2006.

ORGANIZAÇÃO MUNDIAL DE SAÚDE - OMS. Assistência ao parto normal: um guia prático. Genebra: OMS, 1996. 53p.

ORGANIZAÇÃO MUNDIAL DE SAÚDE - OMS. A gravidez na adolescência. Genebra: OMS, 2009.

OSAVA, R.H. Estudo das representações do parto entre enfermeiras de maternidade do Município Paulista. Ribeirão Preto, 1990. 104 f. Dissertação (Mestrado) -Escola de Enfermagem de Ribeirão Preto - USP, Ribeirão Preto, 1990.

OSAVA, R. H. Assistência ao parto no Brasil: o lugar dos não médicos. São Paulo, 1997. 129f. Tese (Doutorado) - Faculdade de Saúde Pública da Universidade de São Paulo, São Paulo, 1997.

OSAVA, R. H.; TANAKA, A. C. D. A. Os paradigmas da enfermagem obstétrica. Rev. esc. enferm. USP, São Paulo, v. 31, n. 1, p. 96-108, Abr. 1997.

PALIBRODA, B. et al. A practical guide to photovoice: sharing pictures, telling stories and changing communities. Winnipeg: Canada. 2009. 84p. Disponível em:

<http://www.pwhce.ca/photovoice/pdf/Photovoice_Manual.pdf>. Acesso em: 20 Mar. 2012.

PAN AMERICAN HEALTH ORGANIZATION - PAHO. Health situation in the

Americas: Basic Indicators 2012. Washington: PAHO. Disponível em <http://ais.paho.org/chi/brochures/2012/BI_2012_ENG.pdf>. Acesso em: 18 Set. 2012.

PARADA, C. M. G. L. Avaliação da assistência pré-natal e puerperal desenvolvidas em região do interior do Estado de São Paulo em 2005. Rev. Bras. Saúde Mat. Infant., Recife, v. 8, n. 1, p. 113-124, Mar. 2008.

PARIS, G. F.; PELLOSO, S. M.; MARTINS, P. M. Qualidade da assistência pré-natal nos serviços públicos e privados. Rev. Bras. Ginecol. Obstet., Rio de Janeiro, v. 35, n. 10, p. 447-452, 2013.

PARIZ, J.; MENGARDA, C. F.; FRIZZO, G. B. A atenção e o cuidado à gravidez na adolescência nos âmbitos familiar, político e na sociedade: uma revisão da literatura. Saúde Soc., São Paulo, v. 21, n. 3, p. 623-636, Set. 2012.

PEDRAZA, D. F.; ROCHA, A. C. D.; CARDOSO, M. V. L. M. L. Assistência pré-natal e peso ao nascer: uma análise no contex to de unidades básicas de saúde da família. Rev. Bras. Ginecol. Obstet., Rio de Janeiro, v. 35, n. 8, p. 349-56, Ago. 2013. 
PEREIRA, C. J.; DOMINGUES, A. L.; MERLO, J. T. Violencia obstétrica desde la perspectiva de la paciente. Rev. Obstet. Ginecol. Venez., Caracas, v. 75, n. 2, p. 81-90, Jun. 2015.

PICCININI, C. A. et al. Gestação e a constituição da maternidade. Psicol. estud., Maringá, v. 13, n. 1, p. 63-72, Mar. 2008.

PICHON-RIVIERE, E. El processo grupal. Aportaciones a la didactica de la psicologia social. Tucuman: Nueva Visión. 2011.

PINOCHET, L. H. C. Tendências de tecnologia de informação na gestão da saúde. O mundo da saúde. São Paulo, v. 35(4), p. 382-394, 2011.

PIMENTA, L. F. Cultura no processo de parturição: contribuições para a enfermagem. Santa Maria, 2012. 91f. Dissertação (Mestrado) - Universidade Federal de Santa Maria Santa Maria, 2012.

POLIT, D. F.; BECK, C. T. Fundamentos de pesquisa em enfermagem: avaliação de evidências e prática da enfermagem. Porto Alegre: Artmed, 7.ed. 2011.670p.

POPE, C.; MAYS, N. Pesquisa qualitativa na atenção à saúde. Porto Alegre: Artmed, 2008. 172p.

PROGIANTI, J. M.; BARREIRA, I. A. A obstetrícia do saber feminino à medicalização: da época medieval ao século XX. Rev. Enferm. UERJ, Rio de Janeiro, v. 9, n.1, p. 91-97, Jan./Abr. 2001.

PROGIANTI, J. M.; LOPES, A. S.; GOMES, R. C. P. A participação da enfermeira no processo de desmedicalização do parto. Rev. Enferm. UERJ, Rio de Janeiro, v. 11, n. 3, p. 273-277, Set./Dez. 2003.

PRUDÊNCIO, P. S.; MAMEDE, F. V. Satisfação com o cuidado pré-natal: contribuição para o quinto objetivo de desenvolvimento do milênio. Cult. cuid. enferm., v. 12, n. 1, p. 61-72, Jun. 2015.

QUEIROZ, M. V. O. et al. Perfil da gravidez na adolescência e ocorrências clínicoobstétricas. Rev. Rene, Fortaleza, v. 15, n. 3, p. 455-462, Maio/Jun. 2014.

RABELO, L. S.; OLIVEIRA, D. L. Percepções de enfermeiras obstétricas sobre sua competência na atenção ao parto normal hospitalar. Rev. esc. enferm. USP, São Paulo, v. 44, n. 1, p. 213-220, Mar. 2010.

RASIA, I. C.; ALBERNAZ, E. Atenção pré-natal na cidade de Pelotas, Rio Grande do Sul, Brasil. Rev. Bras. Saude Mater. Infant., Recife, v. 8, n. 4, p. 401-410, Dez. 2008.

RATTNER D. Humanização na atenção a nascimentos e partos: ponderações sobre políticas públicas. Interface, Comunic, Saúde, Educ, Botucatu, v. 13, supl.1, p. 759-768, Jan. 2009. 
REIS, T. R. et al. Enfermagem obstétrica: contribuições às metas dos Objetivos de Desenvolvimento do Milênio. Rev. Gaúcha Enferm., Porto Alegre, v. 36, p. 94-101, 2015.

RIESCO, M.L.G, TSUNECHIRO, M.A. Formação professional de obstetrizes e enfermeiras obstétricas: velhos problemas ou novas possibilidades? Rev. Estudos Fem., Florianópolis, v. 10, n. .2, p. 449-459, Jul. 2002.

RIESCO, M. L. G. et al. Centros de parto no Brasil: revisão da produção científica. Rev. esc. enferm. USP, São Paulo, v. 43, n. spe2, p. 1297-302, 2009.

ROLIN, K. M. C. et al. Percepções das mães sobre o aleitamento em prematuros da unidade canguru de uma maternidade de Fortaleza-CE. Rev. Rene, Fortaleza, v. 9, n. 2, p. 54-63, Abr./Jun. 2008.

ROSA, R. et al. Mãe e filho: os primeiros laços de aproximação. Esc Anna Nery, Rio de Janeiro, v. 14, n. 1, p. 105-12, 2010.

SAAVEDRA, J. S.; CESAR, A. J. Uso de diferentes critérios para avaliação da inadequação do pré-natal: um estudo de base populacional no extremo Sul do Brasil. Cad. Saúde Pública, Rio de Janeiro, v. 31, n. 5, p. 1003-1014, Maio, 2015.

SABATINO, H. et al. Parto humanizado: formas alternativas. 2.ed. Campinas: Unicamp, 2000. 263p.

SANCHES, M. A.; SIMÃO-SILVA, D. P. Planejamento familiar: do que estamos falando? Rev. Bioética, Brasília, v. 24, n. 1, p. 73-82, 2016.

SANFELICE, C. F. O.; SHIMO, A. K. K. Parto domiciliar: avanço ou retrocesso? Rev. Gaúcha Enferm., Porto Alegre, v. 35, n. 1, p. 157-160, 2014.

SANFELICE, C. F. et al. O. Do parto institucionalizado ao parto domiciliar. Revista Rene, Fortaleza, v. 15, n. 2, p. 362-70, Mar./Abr. 2014.

SANTANA, L. S. et al. Efeito do banho de chuveiro no alívio da dor em parturientes na fase ativa do trabalho de parto. Rev. Dor, São Paulo, v. 14, n. 2, p. 111-113, Jun. 2013.

SANTOS, D. S.; NUNES, I. M. Doulas na assistência ao parto: concepção de profissionais de enfermagem. Esc. Anna Nery, Rio de Janeiro, v. 13, n. 3, p. 582-589, Jul/Set, 2009.

SANTOS, J. O.; TAMBELLINI, C. A.; OLIVEIRA, S. M. J. V. Presença do acompanhante durante o processo de parturição: uma reflexão. Rev. Min. Enferm., Belo Horizonte, v. 15, n. 3, p. 453-458, Jul./Set. 2011.

SANTOS, G. H. N.; MARTINS, M. G.; SOUSA, M. S. Gravidez na adolescência e fatores associados com baixo peso ao nascer. Rev. Bras. Ginecol. Obstet., Rio de Janeiro, v. 30, n. 5, p. 224-231, Maio, 2008. 
SANTOS, S. G. F.; MARQUES, I. R. Uso dos recursos de Internet na Enfermagem: uma revisão. Rev. bras. enferm., Brasília, v. 59, n. 2, p. 212-216, Abr. 2006.

SANTOS NETO, E. T. et al. O que os cartões de pré-natal das gestantes revelam sobre a assistência nos serviços do SUS da região metropolitana da grande Vitória, Espírito Santo. Cad. Saúde Pública, Rio de Janeiro, v. 28, n. 9, p. 1650-1662, Set. 2012.

SCHIMITH, M. D.; LIMA M. A. D. S. Acolhimento e vínculo em uma equipe do Programa Saúde da Família. Cad. Saúde Pública, Rio de janeiro, v. 20, n. 6, p.1487-1494, Dez. 2004.

SEIBERT, S.L.et al. Medicalização x Humanização: o cuidado ao parto na história. Rev. Enferm. UERJ, Rio de Janeiro, v. 13, n. 1, p. 245-251, Maio/Ago. 2005.

SHIMIZU, H. E.; LIMA, M. G. As dimensões do cuidado pré-natal na consulta de enfermagem. Rev. bras. enferm., Brasília, v. 62, n. 3, p. 387-392, Jun. 2009.

SOUZA, D. R. M. A fotografia como ferramenta de reflexão identitária: estudo de caso com jovens em contextos de exclusão social no Brasil e em Portugal. 2013. Tese.

(Doutorado). Universidade Nova de Lisboa. Faculdade de Ciências Sociais e Humanas. Lisboa, 2013.

SILVA, A. L. S.; NASCIMENTO, E. R.; COELHO, E. A. C. Práticas de enfermeiras para a promoção da dignificação, participação e autonomia de mulheres no parto normal. Esc. Anna Nery, Rio de Janeiro, v. 19, n. 3, 424-431, Jul/Set, 2015.

SILVA, E, P. L. et al. Desenvolvimento e aplicação de um novo índice para avaliação do prénatal. Rev. Panam Salud Publica, v. 33, n. 5, p. 356-62, Maio, 2013.

SILVA, L. M. et al. Comunicação não verbal: reflexões acerca da linguagem corporal. Rev. Latino-Am. Enfermagem, Ribeirão Preto, v. 8, n. 4, p. 52-58, Ago. 2000.

SILVA, L. M. et al. Uso da bola suíça no trabalho de parto. Acta Paul Enferm., São Paulo, v. 24, n. 5, p. 656-662, 2011.

SILVA, M. G. et al. Violência obstétrica na visão de enfermeiras obstétricas. Revista Rene, Fortaleza, v. 15, n. 4, 720-728, Jul./Ago. 2014.

SILVA, R. M. et al. Evidências qualitativas sobre o acompanhamento por doulas no trabalho de parto e parto. Ciênc. saúde coletiva, Rio de Janeiro, v. 17, n. 10, p. 2783-2794, Out. 2012.

SIMKIN, P.; BOLDING, A. Update on nonpharmacologic approaches to relieve labor pain and prevent suffering. J Midwifery Womens Health, v. 49, n. 6, p. 489-504, 2004.

SINGHAL, A. et al. Participatory photography as theory, method and praxis: analyzing an entertainment-education project in India. Critical Arts: A South North Journal of Cultural and Media Studies, v. 21, n. 1, p. 212-227, Dec. 2007. 
SKLUS, M. H.; KENNELL, J. H.; KLAUS, P. H. Vínculo: construindo as bases para um apego seguro e para a independência. Tradução de Maria Rita Hofmeister. Porto Alegre: Artmed. 2000. 187p.

SOUZA, C. M. et al. Equipe de enfermagem e os dispositivos de cuidado no trabalho de parto: enfoque na humanização. J. res.: fundam. care. online, Rio de Janeiro, v. 5, n. 4, p. 743-754, 2013.

SOUZA, S. S. et al. Reflexões de profissionais de saúde acerca do seu processo de trabalho. Rev. Eletr. Enf. [Internet], v. 12, n.3, p. 449-455, 2010.

STANCATO, K.; VERGILIO, M. S. G.; BOSCO, C. S. Avaliação da estrutura e assistência em sala de pré-parto, parto e pós-parto imediato - PPP de um hospital universitário. Ciênc. Cuid. Saúde, v. 10, n. 3, p. 541-548, Jul./Set. 2011.

STERN, D. A constelação da maternidade: o panorama da psicoterapia pais-bebê. Porto Alegre: Artes Médicas, 1997.

SOARES, B. A. As emoções da enfermeira na assistência a parturientes. Nursing, São Paulo, v. 4, n. 37, p. 25-30, Jun. 2001.

SOARES, E. S.; MENEZES, G. M. S. Fatores associados à mortalidade neonatal precoce: análise de situação no nível local. Epidemiol. Serv. Saúde, Brasília, v. 19, n. 1, p. 51-60, Jan./Mar. 2010.

SOUZA, C. M. et al. Equipe de enfermagem e os dispositivos de cuidado no trabalho de parto: enfoque na humanização. J. res.: fundam. care. online, Rio de Janeiro, v. 5, n. 4, p. 743-754, Out./Dez. 2013.

TAKEMOTO, A. Y.; CORSO, M. R. Parto humanizado e a assistência de enfermagem: uma revisão da literatura. Arq. ciências saúde UNIPAR; v. 17, n. 2, Maio/Ago, 2013.

UNITED NATIONS POPULATION FUND (UNFPA). The state of world's midwifery 2011: Delivering health, saving lives. New York: UNFPA, 2011. Disponível em: <http://www.unfpa.org/sowmy/report/home.html>. Acesso em: 23 Maio 2012.

TEIXEIRA, N. Z. F.; PEREIRA, W. R. Parto hospitalar: experiências das mulheres na periferia de Cuiabá-MT. Rev. bras. enferm., Brasília, v. 59, n. 6, p. 740-744, Dez. 2006.

TERÁN, P. et al. Violencia obstétrica: percepción de las usuárias. Rev. Obstet. Ginecol. Venez., Caracas, v. 73, n. 3, p. 171-180, Set. 2013.

VELLOSO, F. C. Informática: conceitos básicos. 7. ed. Rio de Janeiro: Campus, 2004.

VENTURI, W. Mulheres brasileiras e gênero nos espaços público e privado. Fundação Perseu Abramo e SESC. 2010. Disponível em:

$<$ http://novo.fpabramo.org.br/sites/default/files/pesquisaintegra_0.pdf >. Acesso em: 2 Ago 2015. 
VETTORE, M. V. et al. Avaliação de qualidade da atenção pré-natal dentre gestantes com e sem história de prematuridade no Sistema Único de Saúde no Rio de Janeiro, Brasil. Rev. Bras. Saúde Mater. Infant., Recife, v. 13, n. 2, p. 89-100, Jun. 2013.

VICTORIA, C. G.; KNAUTH, D. R.; HASSEN, M. N. A. Pesquisa qualitativa em saúde: uma introdução ao tema. Porto Alegre: Tomo Editorial, 2000. 136p.

VIEIRA, B. D. G. et al. As implicações da prática profissional de enfermeiros obstetras egressos da EEAN: a qualidade da assistência. J. res.: fundam. care. online, Rio de Janeiro, v. 5, n. 4, p. 408-416, Out./Dez. 2013.

VILA, V. S. C. O significado cultural do cuidado humanizado em Unidade de Terapia Intensiva: muito falado e pouco vivido. Ribeirão Preto, Dissertação (Mestrado) - Escola de Enfermagem de Ribeirão Preto da Universidade de São Paulo, 2001.

WANG, C.; BURRIS, M. A. Photovoice: Concept, methodology and use for participatory needs assessment. Health Educ. Behavior, v.24, n. 3, p. 369-387, Jun. 1997.

WANG, C. Chapter Nine: Using Photovoice as a Participatory Assessment and Issue Selection Tool (PDF). Archived from the original (PDF) on 2003. Retrieved May 24, 2017.

WANG, C. Photovoice: a participatory action research strategy applied to women's health. J. Women's Health. v. 8, n. 2, p. 185-192, 1999.

WANG, C. C.; PIES, C. A. Family, maternal, and child health through photovoice. Matern. Child Health J., v. 8, n. 2, p. 95-102, Jun. 2004.

WANG, C.C., YI, W.K., TAO, Z.W., CAROVANO, K. Photovoice as a participatory health promotion strategy. Health Promotion International. 1998, 13(1), 75-86.

WEIL, P. The relashionship between investimento in information technology and firm performance: a study of the valve manufacturing sector. Information Systems Research, v. 3, n. 4, p. 307-333, 1992.

WORLD HEALTH ORGANIZATION -WHO. Making Pregnancy Safer: the critical role of the skilled attendant. Geneva: WHO/ICM/FIGO, 2004. Disponível em:

<http://www.who.int/maternal_child_adolescent/documents/9241591692/en/>. Acesso em: 25 Maio 2012.

WORLD HEALTH ORGANIZATION. Baby friendly hospital initiative, revised, updated and expanded for integrate care. Section1, Background and Implementation, Preliminary Version. Geneve: 2006.

WORLD HEALTH ORGANIZATION -WHO. Trends in Maternal Mortality: 1990 to 2008. Geneva: WHO; 2010. Disponível em: <http://whqlibdoc.who.int/publications /2010/9789241500265_eng.pdf>. Acesso em: 23 Maio 2012. 
ZANDT, S. E. V. et al. Nursing Student Birth Doulas' Influence On the Childbearing Outcomes of Vulnerable Populations. Journal of Community Health Nursing, v. 33, n. 3, p. 128-138, 2016.

ZUIN, A. A. S. O plano nacional de educação e as tecnologias da informação e comunicação. Educ. Soc., Campinas, v. 31, n. 112, p. 961-980, Jul./Set. 2010.

ZVEITER, M.; SOUZA, I. E. O. Solicitude constituindo o cuidado de enfermeiras obstétricas à mulher-que-dá-à-luz-na-casa-de-parto. Esc Anna Nery, Rio de Janeiro, v. 19, n. 1, p. 86-92, Mar. 2015. 
APÊNDICES 


\section{APÊNDICES}

\section{APÊNDICE A - ROTEIRO DE ENTREVISTA SEMI-ESTRUTURADA INDIVIDUAL E GRUPO FOCAL}

a) Caracterização dos sujeitos

Nome:

Idade:

Estado Civil: Filhos:

Nível de escolaridade:

Tempo de Formado:

Outra Formação Profissional:

Fez cursos/treinamentos/aprimoramento na área de atuação:

Quais:

Quando:.....

Há quanto tempo trabalha na atenção materna?.

Fale sobre sua trajetória profissional, até trabalhar na assistência a mulher.

O que significa para você trabalhar na admissão, pré-parto, parto e pós parto imediato?

b) Roteiro disparador para a coleta de fotografias

3) Como você percebe a atuação da Enfermeira Obstétrica no seu trabalho?

4) Quais as facilidades e dificuldades enfrentadas no seu ambiente de trabalho?

c) Roteiro para entrevista coletiva

1) Conte-me sobre as facilidades e dificuldades enfrentadas no seu ambiente de trabalho. 


\section{APÊNDICE B - TERMO DE CONSENTIMENTO LIVRE E ESCLARECIDO}

Meu nome é, Maria Angélica Motta da Silva Esser, sou aluna do Doutorado na Escola de Enfermagem de Ribeirão Preto da Universidade de São Paulo-EERP-USP, sob orientação da Prof ${ }^{a}$ Fabiana Villela Mamede.

Você está sendo convidada a participar da pesquisa que estou desenvolvendo com o título: Atuação da Enfermeira Obstétrica: Compreendendo a sua vivência e a realidade da assistência, que tem como objetivo compreender a vivência da enfermeira obstétrica no cenário da admissão, pré-parto, parto e pós-parto imediato e também interpretar os aspectos facilitadores e dificultadores de sua inserção nos serviços de atenção materna.

Essa pesquisa foi aprovada pelo Comitê de Ética em Pesquisa da Escola de Enfermagem de Ribeirão Preto/SP da Universidade de São Paulo (CEP - EERP - USP), que tem a finalidade de proteger eticamente os participantes da pesquisa, conforme determina a Resolução No.466/2012, do Conselho Nacional de Saúde/ MS, que trata da ética em pesquisa envolvendo seres humanos.

A sua participação se dará da seguinte forma:

1) Após o seu aceite, você deverá participar de uma reunião explicativa de todas as atividades a serem realizadas, a ser marcada em horário e local mais conveniente para você. A entrevista individual terá duração prevista de 30 (trinta) minutos e neste momento será explicado como tirar as fotografias de forma a retratar o objetivo da pesquisa. Posteriormente será agendado um encontro em grupo, com duração aproximada de 1 (uma) hora.

2) Você receberá uma câmera fotográfica digital com flash e equipadas com cartão de memória para armazenamento das fotografias, que você deverá utilizar por 7 (sete) dias para fotografar situações relacionadas ao ambiente de trabalho que representem as suas experiências, a sua vivência como enfermeira obstétrica, que possam servir para a compreensão dos temas que permeiam a sua atuação profissional. Você será orientada a usar esse equipamento e, caso você tenha alguma dúvida no decorrer deste período, as pesquisadoras estarão à sua disposição para saná-las; inclusive se houver algum problema com a câmera, a mesma será prontamente substituída. Após esse prazo, as máquinas deverão 
ser devolvidas à pesquisadora, que armazenará as imagens produzidas em um computador e as apagará das máquinas fotográficas.

Caso existam fotografias de pessoas, você deverá solicitar à mesma que assine o Termo de Cessão de imagem anexado a esse termo, em 2 (duas) vias, de maneira que uma fique com a pessoa e uma com você. Esclarece-se que será colocada na foto uma tarja preta nos rostos das mesmas, de maneira que elas não sejam identificadas tanto na utilização para a reunião com as participantes, que deverá ocorrer conforme os detalhes que constam do item a seguir, quanto na utilização na forma escrita e em exposições científicas referentes ao estudo.

3) Você deverá participar da reunião para discutir as fotografias e interpretar os aspectos facilitadores e dificultadores de sua inserção nos serviços de atenção materna, conforme os objetivos da pesquisa. Essa reunião ocorrerá em local de fácil acesso, seguro e confortável e em horário combinado com os participantes, a duração prevista é de 1 (uma) hora.

Ressalto que sua participação é voluntaria e que você tem todo o direito de se recusar a participar da pesquisa, inclusive deixar de participar a qualquer momento, sem que isso venha lhe trazer qualquer prejuízo.

Você não será identificada em momento algum do estudo. O seu anonimato e sigilo dos dados serão mantidos e você receberá uma via assinada desse termo na integra. Também, você não terá nenhum gasto ou receberá alguma recompensa pela sua participação.

Ao término da pesquisa, os dados poderão ser publicados ou apresentados em eventos científicos, com a garantia de não revelar a sua identidade ou de qualquer pessoa pesquisada.

Caso se sinta desconfortável ou sinta-se mal por abordar dificuldades relacionadas ao seu trabalho como enfermeira obstétrica, as pesquisadoras estarão à disposição para dar apoio e suporte necessário. Reitera-se que será mantido todo o sigilo e o anonimato da participação. E, caso venha a ocorrer algum tipo de exposição, os mesmos poderão requerer indenização por parte do pesquisador e das instituições envolvidas pelos danos que porventura vierem a ocorrer nas diferentes fases da pesquisa.

O estudo terá como benefício a possibilidade de colaboração na condução da política de atenção de enfermagem obstétrica traçada pelo Ministério da Saúde à medida 
que os resultados sinalizem informações para a inserção da enfermeira obstétrica na atenção ao parto e, consequentemente, para a mudança do modelo de assistência, reduzindo intervenções desnecessárias, de forma a fortalecer a humanização da assistência e possibilitar maior empoderamento da enfermagem obstétrica.

Agradeço desde já sua colaboração e coloco-me a disposição para quaisquer esclarecimentos e, caso tenha dúvidas ou necessite de maiores esclarecimentos, pode entrar em contato conosco - Maria Angélica Motta da Silva Esser, rua Augusto Balalai, 28, Milton Gavetti, 43 3336-5267/ 43 9809-1991 e mariamds@pitagoras.com.br, ou procurar o Comitê de Ética em Pesquisa Envolvendo Seres Humanos da Escola de Enfermagem de Ribeirão Preto, situado junto a Av. Bandeirantes, 3900, Ribeirão Preto-SP, nos dias úteis das $8 \mathrm{~h}$ às $17 \mathrm{~h}$ ou pelo telefone (16) 3315-3386. Este termo deverá ser preenchido em duas vias de igual teor, sendo uma delas devidamente preenchida, assinada e entregue à senhora.

Londrina, de de 2015.

Declaro que concordo em participar desse estudo.

Declaro também que recebi uma via deste Termo de Consentimento Livre e Esclarecido e que me foi dada a oportunidade de ler e esclarecer as minhas dúvidas

Assinaturas:

Participante da Pesquisa:

Maria Angélica Motta da Silva Esser:

Prof $^{\mathrm{a}}$ Fabiana Villela Mamede: 


\section{APENDICE C - TERMO DE AUTORIZAÇÃO DE USO DE IMAGEM}

$\mathrm{Eu}$ , $\mathrm{CPF}$ RG

AUTORIZO, através do presente termo, os pesquisadores Maria Angélica Motta da Silva Esser, aluna do Doutorado na Escola de Enfermagem de Ribeirão Preto da Universidade de São Paulo-EERP-USP, sob orientação da Prof ${ }^{a}$ Fabiana Villela Mamede e sua colaboradora, a Enfa. Obstétrica do projeto de pesquisa intitulado

“Atuação da Enfermeira Obstétrica: Compreendendo a sua vivência e a realidade da assistência" a realizar as fotos que se façam necessárias. Ao mesmo tempo, libero a utilização destas fotos para fins científicos e de estudos (livros, artigos, slides e transparências), em favor dos pesquisadores da pesquisa, acima especificados, obedecendo ao que está previsto nas Leis que resguardam os direitos das pessoas.

Londrina, _ de ___ de 2015.

Assinaturas:

Pessoa Fotografada:

Maria Angélica Motta da Silva Esser:

Prof $^{\mathrm{a}}$ Fabiana Villela Mamede:

Enfermeira Obstétrica - colaboradora 


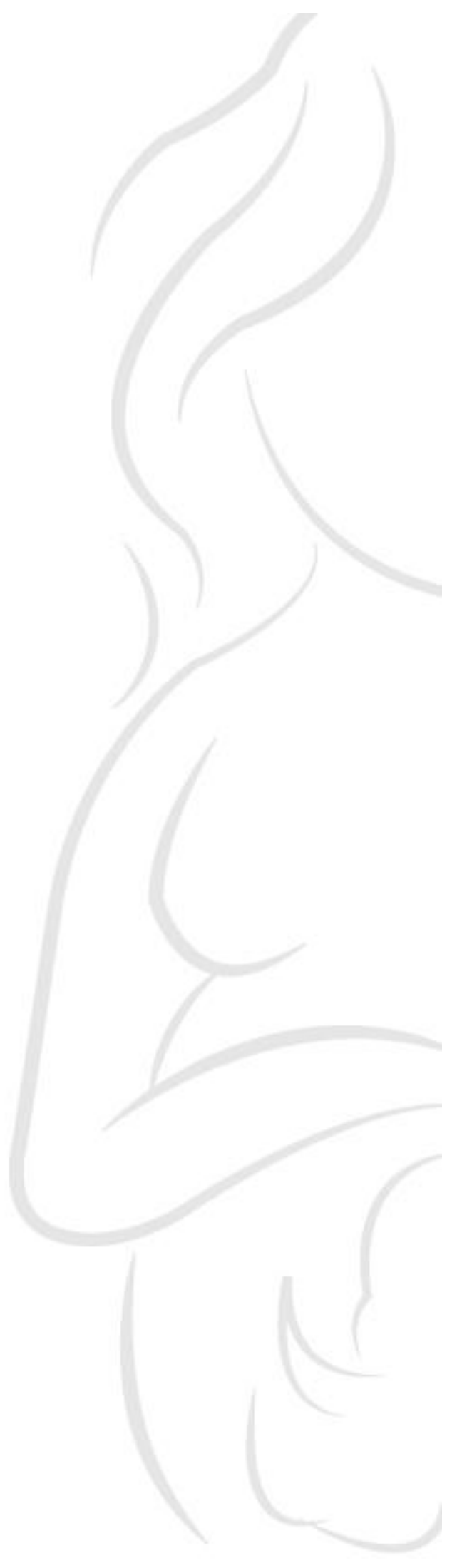

ANEXO 


\begin{abstract}
ANEXO
APROVAÇÃO DO COMITÊ DE ÉTICA EM PESQUISA

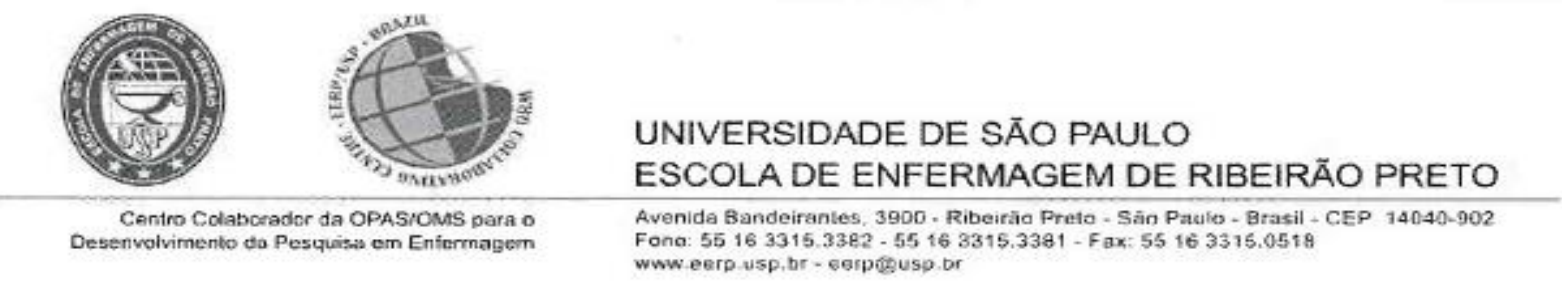

Ofício CEP-EERP/USP nº 183/2015, de 12.11.2015

Prezada Senhora,

Comunicamos que o projeto de pesquisa, abaixo especificado, foi analisado e considerado aprovado "ad referendum" pelo Comitê de Ética em Pesquisa com Seres Humanos da Escola de Enfermagem de Ribeirão Preto da Universidade de São Paulo (CEPEERP/USP), em 11 de novembro de 2015.
\end{abstract}

Protocolo CAAE: 45521615.0 .0000 .5393

Projeto: ATUAÇĀO DA ENFERMEIRA OBSTÉTRICA: COMPREENDENDO A SUA VIVÊNCIA E A REALIDADE DA ASSISTÊNCIA

Pesquisadores: Maria Angélica Motta da Silva Esser

Fabiana Villela Mamede (orientadora)

Em atendimento à Resolução 466/12, deverá ser encaminhado ao CEP o relatório final da pesquisa e a publicação de seus resultados, para acompanhamento, bem como comunicada qualquer intercorrência ou a sua interrupção.

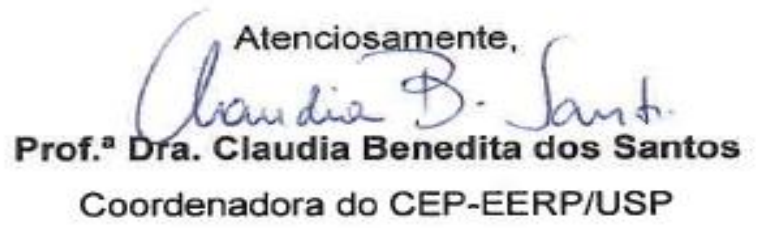

IIma. Sra.

Prof. ${ }^{a}$ Dra. Fabiana Villela Mamede

Departamento de Enfermagem Materno-Infantil e Saúde Pública

Escola de Enfermagem de Ribeirão Preto - USP 